THE NONPROFIT INCORPORATION OF AMERICA, 1860-1932

A Dissertation
presented to
the Faculty of the Graduate School
at the University of Missouri-Columbia
In Partial Fulfillment
of the Requirements for the Degree
Doctor of Philosophy
KORY PAUL GALLAGHER
Dr. Steven Watts, Dissertation Supervisor

December 2020 
(C) Copyright by Kory Paul Gallagher 2020

All Rights Reserved 
The undersigned, appointed by the dean of the Graduate School, have examined the dissertation entitled

\section{THE NONPROFIT INCORPORATION OF AMERICA, 1860-1932}

presented by Kory Paul Gallagher,

a candidate for the degree of Doctor of Philosophy,

and hereby certify that, in their opinion, it is worthy of acceptance.

\section{Professor Steven Watts}

Professor Catherine Rymph

Professor Robert Smale

Professor John Wigger

Professor David Renz 
Dedicated to Galen Burrows, my role model, hero, and Uncle. 


\section{ACKNOWLEDGEMENTS}

If it takes a village to raise a child, it takes a small metropolis to bring a dissertation to completion. The heavy lifting here has been done by my advisor, Dr. Steven Watts, who I will be forever grateful to for sticking with me as I stretched this project out over the years. Additionally, my committee members have my gratitude for their encouragement and patience: Dr. Catherine Rymph, Dr. David Renz, Dr. Robert Smale, and Dr. John Wigger. Though not directly involved in this project, Professors Jerritt Frank, Theodore Koditschek, and Kerby Miller - all University of Missouri faculty - shaped my thinking about history significantly. I would be remiss if I did not also acknowledge LeeAnn Whites, who was singularly responsible for my decision to pursue a $\mathrm{PhD}$ at Mizzou.

Writing, reading, thinking, and teaching history - both for this project and in general - contains a number of pitfalls. For this project, I encountered two amazing archivists at two fantastic archives, Ryan Bean of the Kautz Family YMCA Archive at the University of Minnesota and Craig Wright of the Herbert Hoover Presidential Library. Although I have only know them through their scholarship, William Cronon, W.E.B DuBois, Richard Hofstadter, Ellis Hawley, TJ Jackson Lears, Alan Trachtenberg, Robert Wiebe, and Donald Worster have so impacted the way I look at history it would be impossible to parse out what in my approach is mine and what is from them. Kristen Hoganson, who I have had the honor to meet in person, is responsible for the most important work in my intellectual development. It was in reading her Consumer's Imperium, a book I was not excited to spend time with, that I began to understand how I wanted to approach historical research. Often, teaching has been an excellent way to 
clarify my thinking about history, and over the course of this project I have encountered some excellent students. Especially at the Barstow School, where Elizabeth Bartow, David Cramer, Aaron Ketchell, and Shane Foster took a chance on letting me back in the classroom after three years as an administrator. My first year there I worked with an amazing group of students, the Barstow Class of 2022. On our first day of school together I wondered if I really wanted to teach again, or if I even could. But this group inspired me with their curiosity and bizarre sense of humor, reminding me why I love teaching. My admiration of these students is infinite. On this adventure I have also made use of a mediocre research assistant, Truman the Schnauzer. Though his organizational skills are lacking, he always knows exactly when I need to take a walk and clear my head.

After a long tenure in graduate school, there are others who inspired me along the way. As a student at the University of Missouri-Kansas City (UMKC) I was lucky to cross paths with Professors Diane Mutti-Burke and John Herron, who quickly became mentors, advocates, and friends. Much of my ability to navigate this project can be attributed to the lessons learned working with my Master's advisor, Dennis Merrill. While this project is clearly rooted in history, it draws heavily from my experience as a student in the Public Administration program at UMKC's Bloch School of management. Professors David Renz, Scott Helm, Bob Herman, and Nicholas Peroff provided the fuel for this project as they were introducing me to Nonprofit management.

Graduate school is not a solitary experience. At UMKC I found a community of graduate students that was competitive, supportive, and a ton of fun. Between arguing history with Melissa Riebe and arguing college basketball with Chainy Folsom, it was my peers more than anything who gave me the confidence to continue on to a $\mathrm{PhD}$ program. 
At Mizzou, I quickly found a group of likeminded students of history, who have become more like family than friends. When the challenge of comprehensive exams or a dissertation seemed to big, it was Chad Denton, Bob Fisher, Jonathan Root, and Patrick Witt who reminded me it was manageable.

I am lucky to have the support of an amazing family to carry my through all obstacles. My mother, Marolyn White, who taught me grit with her inexhaustible example. My father, Lance Gallagher, who checked up on this project regularly to encourage me to completion. My step-parents, David White and Tracy Gallagher, who I am sure politely listened to me go on about history as a child. My second set of parents, my Aunt and Uncle, Carolyn and Galen Burrows. My grandmother, June Yager, who always knew I would get here somehow. My brothers, Jeff and Nick Gallagher, who I am sure I also annoyed with history as a child. My faux in-laws, Anne and Mike Prettejohn, who adopted me as one of their own. And my brothers from another mother - without whom I am certain I would have never made it out of high school - Patrick Martinez, Eddie Martinez, Steve Martinez, Mark Pash, and George Tholborn.

The last person I want to thank is Dr. Amy Prettejohn. From love and encouragement to making sure that our shared mail was addressed to Dr. Amy and Mr. Kory to shame me, this project would not have happened without her. She even sustained an injury accompanying me on a research trip! Had our paths not crossed I am certain I would have gone to law school, and been miserable. But she lit another path and that has been the second best decision of my whole life. Of course, the best decision of my life came as an undergraduate student, when I over-drafted my checking account to pay the 
cover charge to meet her for our second date. I am forever indebted to her for always reminding me that I was capable of finishing this, especially when I doubted it the most. 


\section{TABLE OF CONTENTS}

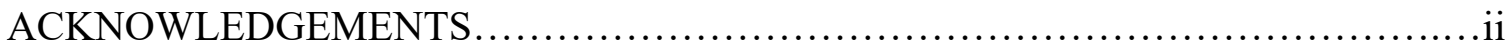

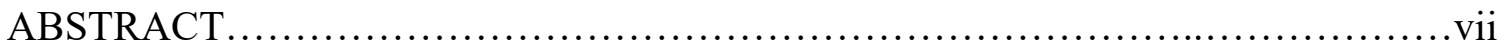

Chapter

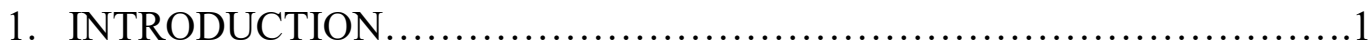

2. THE UNITED STATES SANITARY COMMISSION......................14

3. THE FREEDMEN'S BUREAU ..........................................50

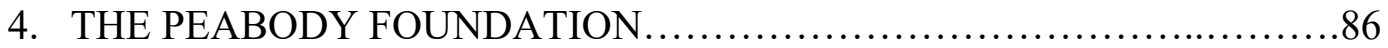

5. THE SLATER FUND .................................................113

6. YOUNG MEN'S CHRISTIAN ASSOCIATION...........................148

7. THE AMERICAN NATIONAL RED CROSS.............................194

8. THE RED CROSS AND YMCA GOES TO WAR .........................238

9. THE LIMITS OF THE ASSOCIATIONAL STATE......................267

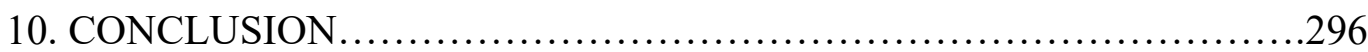

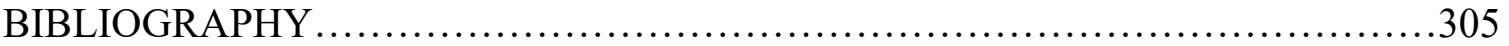

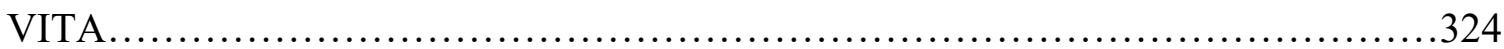


THE NONPROFIT INCORPORATION OF AMERICA, 1860-1932

Kory Paul Gallagher

Dr. Steven Watts, Dissertation Supervisor

\begin{abstract}
This project is an examination of the formation of corporatized charitable organizations from 1860-1932. Focusing on six organizations - the United States Sanitary Commission, the Freedmen's Bureau, the Peabody Foundation, the Slater Fund, the American National Red Cross, and the Young Men's Christian Association - it encourages scholars to view large-scale charities as more than good works, instead acknowledging the inherently corporate nature of nonprofit corporations. This study makes three arguments. First, the experience of the Civil War produced two possible paths to a modern civil society, with the model of independent organizations winning out over direct government intervention. Second, into the void left by the federal government's exit came private foundations, which desired to operate in a corporate manner, while expecting a corporate culture among those receiving their funds. This led to the corporatization of organizations that sought legitimacy in the eyes of major donors. Third, with organizations becoming corporatized, they were welcomed into the government-big business-association alliance that became the basis for governing in lieu of direct federal intervention. A system which was exposed as not up to the task presented by the Great Depression as it failed to respond appropriately to a drought in Arkansas in 1932.
\end{abstract}




\section{Chapter 1}

Introduction

Like many graduate students, I spent my summers doing odd jobs. From working in a lumberyard to stocking shelves at a big box retailer, I have done it all. My most interesting summer gig was working for the Kansas City chapter of the International Visitors Council. For two weeks I was overpaid to drive around twelve mid-level bureaucrats from Azerbaijan as they observed America's nonprofit sector in action. We visited a Head Start program, a Boy Scouts inspired organization aimed at teaching urban youth life skills, a life enrichment program for people with developmental disabilities, homeless shelters, food pantries, international relief organizations, community organizers, and the local Chamber of Commerce. For these international visitors the cornucopia of American philanthropy was on display, conveying a message that because of their willingness to organize and raise funds the American people asserted leadership over their communities. Perhaps most importantly, neither direction nor funds from the government were needed to have an impact.

While always polite and respectful, the Azerbaijanis were skeptical at best. In the organizations we visited Americans saw democracy in action; the Azerbaijanis saw disorganization, an unnecessary diffusion of resources, overlapping goals, and repetition of administrative duties. Through their eyes the American nonprofit sector was not democracy in action. It was simply wasteful. As we walked the aisles a Target store one afternoon, they asked about centralization: "Would it not be easier to do these things through the government?" My reply was that this was the American way of handling many problems. They asked why. 
I shrugged my shoulders and pointed out the new hot video game, yet, this question has stuck with me for years now. This project represents an attempt to provide an answer. Certainly other scholars have tackled the role of nonprofits in American civil society. ${ }^{1}$ Outside of that limited literature, rather than treating the nonprofit sector as a fundamental part of American life, historians tend to view nonprofits as if they existed in a vacuum. If other historical developments enter the landscape of the nonprofit sector it is simply a mention of their good works. Especially during the period under consideration here, a time when scholars fail to recognize that a nonprofit sector was even forming. For example, the only serious academic attempt to identify the beginning of the nonprofit sector, Peter Dobkin Hall's Inventing the Nonprofit Sector, points to the 1970s, well after the events examined here. ${ }^{2}$ It is not that historians fundamentally misunderstand the role of nonprofit corporations; rather, historians have failed to engage with these important cultural and economic actors in a meaningful way.

The search for an accurate view of the nonprofit sector brought my gaze to the beginning of the Civil War. This massive administrative, economic, and logistical undertaking occurred without benefit from an extensive, nationalized civil society structure. Quick change was required. Organizations emerging in the decades following the Peabody Foundation, the Slater Fund, the Red Cross, and the Young Men's Christian

${ }^{1}$ See Kathleen McCarthy, American Creed: Philanthropy and the Rise of Civil Society, 1700-1865 (Chicago: University of Chicago Press, 2003); David C. Hammack, Making the Nonprofit Sector in the United States (Bloomington: University of Indiana Press, 1998); Robert Bremner, American Philanthropy (Chicago: University of Chicago Press, 1988).

${ }^{2}$ Peter Dobkin Hall, Inventing the Nonprofit Sector and Other Essays on Philanthropy, Volunteerism, and Nonprofit Organizations (Baltimore: Johns Hopkins University Press, 2001). 
Association (YMCA) - triggered a small but significant evolution. Through the Red Cross and YMCA, perhaps the two most prominent nonprofit corporations in modern American history, the relationship between the government and the third sector of the economy developed further, resulting in a high degree of cooperation and coordination, what historian Ellis Hawley termed "the Associational State." In Hawley's analysis of the Associational State - an alliance between government, big business, and associations, which included nonprofit corporations - organizations like the YMCA and the Red Cross played a significant role in alleviating social ills. What Hawley did not address was how and why these organizations found inclusion in an informal governing system primarily concerned with the economy. To be fair, he was not all that concerned with the contribution of these organizations.

The theory of an Associational State has not sat idle since Hawley's examinations. Other scholars, such as Louis Galambos, Jeffrey Lustig, Suzanne Mettler, Andrew Milstein, and Stephen Skowronek - all exploring the field of American Political Development - have examined Hawley's interpretations and expanded our understanding of how the Associational State functioned. ${ }^{3}$ But perhaps the most significant advancement in the study of the Association State is Brian Balogh's The Associational

${ }^{3}$ See the following for examples of their scholarship: Louis Galambos, "The Emerging Organizational Synthesis in Modern American History," Business History Review (1970); Jeffrey Lustig, Corporate Liberalism: The Origins of Modern American Political Theory, 1890-1920 (Berkeley: University of California Press, 1982); Suzanne Mettler and Andrew Milstein, “American Political Development from Citizens' Perspective: Tracking Federal Government's Presence in Individual Lives over Time," Studies in American Political Development (2007); and Stephen Skowronek, Building a New American State: The Expansion of National Administrative Capacities, 1877-1920 (New York: Cambridge University Press, 1982). 
State: American Governance in the Twentieth Century. ${ }^{4}$ Largely a work of

historiography, Balogh lays his research over the top of existing works to produce novel interpretations of the Associational State. This new way of governing, according to Balogh, was essentially a compromise between American's demand for government intervention, in particular in the economy, coupled with distinct cultural distrust of government. This left governments in American, from the federal government to local governments, searching for a way to demonstrate engagement while hiding activity. Therefore, new government initiatives sought out partners - be they large corporations, other governments (the federal government handing off to state or local governments, for example), or nonprofit organizations - to execute plans and take responsibility for operations. In effect, Balogh finds that the Associational State produced government intervention without the appearance of government. And while his research does much to push the Associational State farther into the light of day, much like Hawley, Balogh never directly addressed the role of nonprofit organizations or why some were invited into the system while others were excluded. Nor do any of these scholars acknowledge the corporate nature of nonprofit corporations. Seeing nonprofits for what they are $-\mathrm{a}$ progeny of the market economy - is revealing exercise.

This examination produced three distinct interventions in the existing literature, which though seemingly independent, interlock to create a new view of the foundation of the modern nonprofit sector. First, the experience of the American Civil War produced two possible paths to inform the evolution of civil society moving forward. The road

\footnotetext{
${ }^{4}$ Brian Balogh, The Associational State: American Governance in the Twentieth Century
} (Philadelphia: University of Pennsylvania Press, 2015). 
rejected was a system guided by the federal government, in which institutions could look to Washington, DC for direct funding and support of missions furthering public policy. Especially in the years following the war, as the federal government shrank and dispensed with certain operations, space for this type of experimentation existed. Instead, the federal government retreated from direct involvement in the emerging nonprofit sector, allowing other factors to guide its evolution over the next seventy years. Second, with the federal government no longer a significant influence on organizations, private groups came to compete for donors and dollars in a free market of services and missions. Vying for resources in a competitive environment governed by the laws of capitalism, much in the same way as for-profit corporations, these groups saw that adapting organizational cultures to corporate mores became fundamental to success. Those that adopted a corporate culture - clear policies and procedures, expert financial management, strategic planning, mission and operational alignment - thrived and transitioned from amateurish charities to nonprofit corporations. Third, because organizations were willing to impose a corporate culture on themselves, and fully become nonprofit corporations, they received recognition from the government and inclusion in the Associational State: an alliance between the federal government, private industry, and 'associations' (often business associations such as the Chamber of Commerce, but also the Red Cross and YMCA) organized to address societal needs in a voluntary and, at least in theory, democratic manner. ${ }^{5}$ A proto version of this system emerged during the Civil War, demonstrating that in times of extreme need the government was willing to offload

${ }^{5}$ Ellis Hawley, The Great War and the Search for a Modern Order: A History of the American People and Their Institutions, 1917-1933 (New York: St. Martin Press, 1979). 
critical operations to non-governmental entities. This system was brought fully to fruition with the Great War, in 1917-1918. It was then disrupted by the Great Depression and the changing economic landscape impacting for-profit and nonprofit corporations alike. But in its wake, a clear nonprofit sector emerged, which remains the centerpiece of American civil society today. Although this project does not fully answer the question posed by my friends from Azerbaijan, it provides a launching point for a more searching examination of the role of nonprofit corporations in the culture of modern America.

This is not to say that this topic has been completely ignored by scholars. There are laudable, if flawed, histories of particular nonprofit organizations, especially among the organizations that loom large in the American nonprofit sector. The YMCA has been examined by notable scholars, along with countless works of local history detailing the trials and triumphs of individual chapters. ${ }^{6}$ A limited, though quality, academic literature exists for the Red Cross. ${ }^{7}$ Yet, these organizations, like the nonprofit sector in general, remain quietly in the background of historical narratives. Even when brought to the forefront, however, the best of scholars make the same error when discussing nonprofits:

${ }^{6}$ Detailing even a small portion of the works focused on individual chapters would be a fool's errand. Notable works examining the larger YMCA include: David I. Mcleod, Building Character in the American Boy: The Boy Scouts, YMCA, and Their Forerunners, 1870-1920 (Madison: University of Wisconsin Press, 1983); Nina Mjagkij, Light in the Darkness: African Americans and the YMCA, 1852-1946 (Lexington: University of Kentucky Press, 2015); Paula Lupkin, Manhood Factories: YMCA Architecture and the Making of Modern Urban Culture (Minneapolis: University of Minnesota Press, 2010); and Clifford Putney, Muscular Christianity: Manhood and Sports in Protestant America, 1880-1920 (Cambridge: Harvard University Press, 2003).

${ }^{7}$ Marian Moser Jones, The American Red Cross From Clara Barton to the New Deal (Baltimore: Johns Hopkins University Press, 2013); John F. Hutchinson, Champions of Charity: War and the Rise of the Red Cross (Boulder: Westview Press, 1996); 
they detach the good works performed by organizations from the economic realities in which they operated. Market pressures impacted nonprofits consistently, demonstrating that these organizations were part and parcel of the culture of capitalism - a sibling of the for-profit corporation. The fracturing of mission from financial realities, combined with a persistent blind spot in recognizing the development of corporatized charity, not to mention a whole sector of the economy consisting of these organizations, has produced a limited perspective.

Clifford Putney in Muscular Christianity notably falls into this trap. His research demonstrating the cultural influences within Protestant Christianity during the Gilded Age, which helped transform the YMCA from an evangelical men's organization noted for their reading rooms into gymnasiums, is foundational. But his assumption that the YMCA transformed because of a new link between faith and health fails to account for the financial insecurity of the organization. When 'muscular Christianity' became an acceptable expression of faith, YMCAs across the United States were largely pinched for resources. In ignoring the realities of an organization constrained by its ability to appeal to a market of donors and members, Putney misunderstood the direction of change. The YMCA did not become a gymnasium only because of the emergence of a connection between faith and health. This change also created an opportunity for a financially failing organization to find stability.

Even Ellis Hawley, whose research is the foundation of this project, missed the thread when it comes to nonprofit corporations. He correctly asserts that during the Great War and decade following, through the vision of Herbert Hoover, America began to address social ills through the Associational State. Hawley's assertion that the 
government, big business, and what he termed "associations" (generally business associations, but he includes in this alliance what I term "nonprofit corporations" in this project) aligned to find voluntary solutions to the needs of society and meet public priorities. ${ }^{8}$ Although Hawley leaves the role of nonprofit corporations largely unexplored, it is clear that he viewed their participation in the associational state as central, ultimately reaching an apex point in 1931. With the coming of the New Deal, coordination between government, business, and associations moved off stage as the federal government became involved in directing relief efforts. ${ }^{9}$ But without a clear conception of how nonprofits fit within the free market system, Hawley was largely left without an explanation of how these organizations fit into the Associational State. Viewing nonprofit corporations as a third sector of the economy, and thus fully centered in capitalism, was the missing key.

The nonprofit sector involved organizations that function as a third sector of the national economy. Early in the American republic, significant charities had a noteworthy impact. Founded in 1819, the Savings Bank of New York, an early experiment in financial services to serve the public rather than distribute profit, held such large deposits that it became the most important institutional investor in the building of the Erie Canal. ${ }^{10}$

${ }^{8}$ Ellis Hawley, The Great War and the Search for a Modern Order: A History of the American People and Their Institutions, 1917-1933 (Long Grove, Il: Waveland Press, 1997).

${ }^{9}$ The system, however, never failed to recede. Nonprofit corporations continue to play an important, though secondary, role in meeting national priorities, from hurricane relief to low-cost childcare.

${ }^{10}$ Kathleen D. McCarthy, "Spreading the Gospel of Self-Denial: Thrift and Association in Antebellum America," ed. Joshua J. Yates and James Davison Hunter, Thrift and Thriving in America: Capitalism and Moral Order from the Puritans to the Present (New York: Oxford University Press, 2011), 162 
Likewise, the American Sunday School Union, though experiencing a relatively short lifespan, built a network of Sunday schools that at its height influenced the teachings of more than 8,000 churches nationwide. ${ }^{11}$ Although these organizations were influential, their impact was hardly large enough to classify as a third sector of the economy. To reach that level of import, organizations had to transform into nonprofit corporations, create a national impact, and spawn other organizations. The precise point at which a nonprofit sector exists is difficult to pinpoint, but the die was cast during the American Civil War.

Because historians regularly fall into the trap of viewing nonprofit organizations only in terms of their good works, or occasionally their scandals, a full view of the beginnings of the nonprofit sector is needed. While small charities continued to exist, functioning in a generally ad hoc way, avoiding a corporatist approach to their practices, this study is not concerned with them. Instead, the big organizations that became national in scope - if not in mission, at least in fundraising; that adopted corporate methods of accounting, management, logistics; that leveraged new technologies and methods to improve fundraising. These organizations left behind their peers and became instead nonprofit corporations; with an emphasis on corporate. ${ }^{12}$ They also became important components of civil society in modern America; a civil society rooted in a free market of resources.

${ }^{11}$ Ibid., 166-167

${ }^{12}$ Throughout this study the term 'nonprofit corporation' is used to describe organizations that adapted a corporate approach to business functions, resulting in a strong corporate culture. This is not to be confused with the modern day use of the term, which is largely a legal identification applying to a range of organizations recognized as serving a public good, whose donors receive a tax benefit for donations. 
The following chapters examine historically the emergence of nonprofit corporations. In chapter two and three, the United States Sanitary Commission (USSC) and the Freedmen's Bureau come under the microscope. Though it would still be difficult to say that a nonprofit sector is formed in the Civil War, these two organizations provided two clear and distinct paths for how civil society could have evolved following the conflict. The USSC provided a perfect example of a large, traditional nonprofit corporation. With a corporate culture in place, the USSC worked tirelessly to address the needs of the soldiers in the field, from basic medical services to ensuring they received their mail. By the end of the war the federal government viewed the USSC as an important factor in the functioning of the army; demonstrating that the associational state, at least in proto form, pre-dates Herbert Hoover.

Shortly after the war, the Freedmen's Bureau encountered its own unique problems. Although a bureau of the federal government, responsible for the care of the freed people in terms of basic life necessities as well as civil rights and economic opportunity, the Freedmen's Bureau faced constant organizational challenges. Gradually, it was forced to operate more like a nonprofit corporation than a traditional government entity, in the process creating a novel approach to American civil society.

Chapters four and five move to philanthropists, specifically George Peabody and the Peabody Foundation, and John Slater and the Slater Fund, founded following the Civil War (1867 and 1881 respectively). Both foundations represented an early example of the transfer of wealth from a significant capitalist to a growing sector of the market economy, nonprofit corporations. Rather than challenging the economic status quo, or 
questioning the role of the government in social and economic improvement, these men sought to make improvements via the same mechanisms that produced vast sums for themselves.

Chapters six and seven examine the challenges and victories of two distinct nonprofit entities, each with a unique and telling structure: the Young Men's Christian Association and the American National Red Cross. While there was an overarching national YMCA organization, it acted more as a coordinator than an authority - each local chapter maintained their own management structure, interpretation of the organization's vision, policies and procedures, and fundraising efforts. Yet, in short order, the operations, management, policies and procedures of each of the chapters became corporatized. A similar transition from charity to nonprofit corporation is found with the Red Cross. Though that organization also consisted of chapters, the national parent organization held significant sway and authority over the dependent local versions. This relationship provided a clear top-down conduit for the corporatization of the organization's culture. By the 1890s the Red Cross blossomed into an organization national in scope, capable of remarkable relief efforts, but increasingly incapable of responding to organizational challenges. With the coming of the Great War, the YMCA and Red Cross provided instrumental service to the war effort, a development examined in chapter eight. They transformed their management and operations in the months prior to contribute in a meaningful way to the war effort. Although not perfectly executed, or reliably efficient, the participation by nonprofit corporations in the war effort demonstrates one aspect of the ideal functioning of the Associational State. 
Chapter nine focuses on one event: the coming of drought in 1930. As this event unfolded the American people and the federal government looked to the Red Cross to provide relief. Just three years prior, the Red Cross responded admirably to tremendous flooding throughout the Mississippi River Valley, and now another section of the South, Arkansas in particular, presented as a worthy candidate for relief. With the Great Depression unfolding, the Red Cross' leadership began to worry about its ability to sustain a massive relief effort, in particular one completely dependent on the weather for resolution. The public and Congress became concerned that without additional funding awarded to the Red Cross the suffering in Arkansas would continue unabated. The leadership of the organization, including Herbert Hoover who by virtue of being President of the United States also served as president of the Red Cross, worried what direct government intervention would mean for the future of philanthropy and the Associational State. Accepting funds from the government, in Hoover's estimation, became the same as an active, and eventually oppressive, federal government, taking up the obligation of the people, expressed through associations, both public and private. Regardless of the human tragedy unfolding, limiting the scope and power of the federal government, while empowering the American people through organization, remained tantamount.

Ultimately this study does not aim for an exhaustive history of the development of the nonprofit sector from the Civil War to the Great Depression. Instead, by tracking the two paths offered by the experience of war in the 1860s, to corporatized giving in the Gilded Age, and the transition from charity to nonprofit corporation by two major organizations, followed by the greatest success and most significant failure of the 
Association State, it aims to highlight how nonprofit corporations became a significant part of the modern American social and economic system. Important stories remain and counter examples need to be explored. But this examination represents a hopeful beginning. 


\section{Chapter 2}

\section{The United States Sanitary Commission}

As the battle of Antietam ended, army surgeon Alfred Lewis Castleman reflected on the wave of wounded soldiers making their way back to camp. Once ensconced in the safety of their lines, the misery did not cease. "Our wounded suffered much to-day [sic] for want of chloroform."1 Surgeons were finding their supplies perilously low, "the few pounds on hand were exhausted in less than three hours. The men lay suffering from their wounds, and in many instances surgeons were operating without it."2 The agony was so great that Castleman wondered "why will surgeons permit themselves on a campaign like this to be without the necessary article of comfort for the wounded?"3 That Castleman would resign his post in December provides some clue as to how he would answer this question. ${ }^{4}$ But on September $17^{\text {th }}, 1862$ there was too much trauma to ponder this existential crisis. Unsure what to do without the necessary supplies, and no government supply train on the horizon, the surgeon's prayers were suddenly answered. 'In this dilemna [sic], at the very right moment, in stepped Mrs. Harris, of Philadelphia, with the announcement that she had just arrived with twenty pounds of chloroform from the U.S. Sanitary Commission. What an angel of mercy is this Mrs. Harris!"5 As much as he was pleased to see Harris, praise was spread around. "What a source of ever present comfort

\footnotetext{
${ }^{1}$ Alfred Lewis Castleman, Diary of Alfred Lewis Castleman, 5. Accessed via "Illustrated Civil War Newspapers and Magazines."

${ }^{2}$ Ibid.

${ }^{3}$ Ibid.

4 "Alfred Lewis Castleman," Wisconsin Historical Society, https://www.wisconsinhistory.org/Records/Article/CS6166.

${ }^{5}$ Castleman, 5.
} 
and well directed effort is that sanitary commission! The soldiers of this army will have cause of prayer for it in their living and in their dying hours." ${ }^{\circ}$ Castleman understood that Mrs. Harris would not have been able to meet their need without the structure of the United States Sanitary Commission behind her.

Stories such as Castleman's are not unusual. Diaries of soldiers and published articles with news from the front are replete with tales of the Sanitary Commission at work. Noted scholar and eventual chair of the literature department at the University of Missouri, James Kendall Hosmer, tells of a similar experience in his diary. A minister by training, Hosmer found himself regularly assigned to provide comfort to the soldiers in the hospital, and on the second day of Gettysburg there were many who needed comfort. Like Castleman, Hosmer encountered a medical staff spread perilously thin, supplies well depleted. Among the medical staff Hosmer encountered that day was a Dr. Barclay, who was not a military doctors, but instead an agent of the Sanitary Commission. As the needs of the wounded expanded, Barclay was able to find a solution: "I do not know where he keeps them; but it seems as if he must have them in some way compressed into his pocket, so readily does he produce clean white garments, pillows, towels, whenever they are needed."'7 From Hosmer's vantage point, Barclay's ability to call up supplies on demand seemed somewhat magical. Given that the Sanitary Commission was a first of its kind organization, attributing its activities to something otherworldly is excusable. The answer to why Barclay was able to be in the right place, at the right time, with the right supplies - just like Castleman's Mrs. Harris, and countless other agents of the Sanitary

\footnotetext{
${ }^{6}$ Ibid., 5.

${ }^{7}$ James Kendall Hosmer, Diary of James Kendall Hosmer, 4. Accessed via "Illustrated Civil War Newspapers and Magazines."
} 
Commission - was far from magical. Instead, it was the application of two ideas in their infancy. The creation of the Sanitary Commission was perhaps the first experiment with the Associational State. Under that theory of governing, the Federal government, in conjunction with private enterprises- in this case a charitable organization - work through voluntary methods to meet the demands of the day. But, inclusion in the Associational State was predicated on being organized and efficient enough in management to be viewed as reliable partner in a great effort. In the Sanitary Commission the first significant application of corporate culture to charity comes into view, creating the foundation, and demonstrating the future, of the nonprofit sector of the American economy. By the end of the war, the Commission's economic impact was sizeable - raising more than $\$ 15,000,000$ in support of the soldiers. With these two aspects of the organization working in concert to chart a new path for philanthropy in America, the shadow cast by the Sanitary Commission is of such significance that the associational state and the nonprofit corporation, even in the present, are largely bound by its form.

Charity has a long and storied history in the United States, and it certainly does not begin with the United States Sanitary Commission. But with the coming of this organization, as well as the Freedmen's Bureau, the beginning of a nonprofit sector takes shape. The difference between the charity of the antebellum years, and even the smaller volunteer managed charities of today, with the Sanitary Commission and organizations of its ilk - truly nonprofit corporations - is professionalization. Or, to be more precise, the application of a corporate culture to the execution of mass charity. 
Early in the American republic, significant charities held noteworthy impact. Founded in 1819, the Savings Bank of New York, held such large deposits that it became the most important institutional investor in the building of the Erie Canal. ${ }^{8}$ Likewise, the American Sunday School Union, though experiencing a relatively short lifespan, built a network of Sunday schools that at its height influenced the teachings of more than 8,000 churches nationwide. ${ }^{9}$ Although these organizations were influential, their impact was hardly large enough to classify as a third sector of the economy. To reach that level of import, charities required transformation into nonprofit corporations, through the adoption of a corporate culture, as demonstrated by bureaucratic standardization. Olivier Zunz, in his classic examination of corporatization, defined the end result of a corporate culture as "...managers who made decisions, devised standardized ways of working..." coupled with a weakened "... significance of geographical boundaries within regions and reduced the de facto cultural autonomy that has characterized many communities."10 Though only beginning to take shape, the seeds of this culture, and their application to charity, are evident in the activities of the Sanitary Commission. In creating a defined mission, national in character, building a culture of bureaucratic standardization, even if a challenged effort, and rising to a position of cultural prominence resulting in their efforts being coopted and expanded by others - the Sanitary Commission set a new course for the history of charitable organizations. Its emergence makes clear that the die of the

\footnotetext{
${ }^{8}$ Kathleen D. McCarthy, "Spreading the Gospel of Self-Denial: Thrift and Association in Antebellum America," ed. Joshua J. Yates and James Davison Hunter, Thrift and Thriving in America: Capitalism and Moral Order from the Puritans to the Present (New York: Oxford University Press, 2011), 162

${ }^{9}$ Ibid., 166-167

${ }^{10}$ Oliver Zunz, Making America Corporate 1870-1920, (Chicago: University of Chicago Press, 1990), 5.
} 
nonprofit sector is cast during the American Civil War. And the United States Sanitary Commission, in conjunction with the Freedman's Bureau, became the model by which nonprofit corporations would be organized, managed, and restricted.

At the same time, the emergence of new thinking on the relationship between the government and charity - at least charity organized along corporate lines - becomes evident. It would be difficult to firmly claim that the associational state found in the age of Hoover is fully developed and implemented in the American Civil War. The relationship between the Sanitary Commission (and the Freedmen's Bureau in the next chapter) and the federal government, however, is an early experiment in this arrangement. An initial first step in building the associational state which will ripple through other organizations and future crisis.

The Sanitary Commission in particular was the model that spawned future nonprofit corporations. Its beginning was truly unique - in a world without standardized nonprofit law, it was essentially created out of thin air by the War Department. In the days following the election of Abraham Lincoln to the White House, as passions stirred and the Confederacy took shape, a handful of ministers, professors, doctors, and philanthropists from throughout the cities of the East lived in fear. Not of war - that was clearly inevitable. But of what war would bring. The British experience in the Crimean War fueled these fears. Known more for the poetry it inspired than any actual warfare, the conflict reeked havoc on the British army not primarily because of violence, but from the inability to organize a proper response to the medical needs of soldiers. As heroes of an emerging medical service gained notoriety, most notably Florence Nightingale, anger 
at the medical treatment the troops received boiled over. Before their guns were silenced the British undertook a study of their failings and produced a number of reports, pamphlets, and scholarly works that would form the basis of proactive wartime medicine. ${ }^{11}$ Those men of various backgrounds who worried that the United State would fail to learn these lessons advocated for the creation of a new entity in American life. They named it the United States Sanitary Commission.

The Commission's mission was relatively straightforward at the beginning of the conflict. First, paid staff of the organization would travel with, and circulate among, the armies fighting to reunite the United States, inspecting and collecting information on the medical services provided to the soldiers, and build on the body of knowledge created by the British experience of the previous decade. Second, those inspectors would provide advice and guidance to the medical staff and command officers in the field to improve medical treatment and camp life. The leadership of the organization, collating information from the field, provided advice and guidance to the command staff and civilian leadership in Washington, DC to address systemic deficiencies. Last, as needed, the organization would help provide additional resources, either in donated items or funds, to ensure fully functional and well-stocked field hospitals and other medical facilities. ${ }^{12}$ Although last of their priorities, it is for these philanthropic efforts that the Commission is most remembered.

${ }^{11}$ Charles J. Stille, History of the United States Sanitary Commission (Philadelphia: J.B. Lippincott \& Co., 1866), 27-28.

${ }^{12}$ Frederick Law Olmsted, The Papers of Frederick Law Olmsted, ed. Jane Turner Censer, Vol. IV, "Olmsted to Bellows, September 1" ${ }^{\text {st }}$ 1863" (Baltimore: The Johns Hopkins Press, 1986), 704. 
The organization of the Commission, while unique for its time, is familiar in our own. The men with whom the idea originated became its Board of Directors, with each director serving on various committees creating policy for the paid staff to implement. The primary thought leader behind the organization, the Reverend Henry Bellows, became its President. To manage the day-to-day activities of the new organization the board created the position of General Secretary, in essence the first professional nonprofit Executive Director in American history. To fill this position Bellows recommended, and the board consented to, hiring none other than Frederick Law Olmsted. Most famous in our time as a landscape architect, Olmsted was heralded in his own as a public intellectual, a journalist and scholar, a landscape architect certainly, but most important as demonstrated by his management of the Central Park development project - a master of organizing complex efforts and managing administrative minutia. With an organization in place all that waited was official recognition.

The United States Sanitary Commission came to life on June $9^{\text {th }}, 1861$ by order of the Secretary of War, Simon Cameron. He instructed his subordinates to provide the Commission with access to their camps and hospitals, so that they could inquire as "...to the principles and practice connected with the inspection of recruits and enlisted men, the sanitary condition of volunteers, to the means of preserving and restoring health and of securing the general comfort and efficiency of the troops, to the proper provision of cooks, nurses, and hospitals..."13

${ }^{13}$ Stille, 63. 
He instructed that they should "...correspond freely with the Department and with the Medical Bureau concerning these subjects, and on this footing and without these limits, their relations with the official authorities were established."14 Existing outside of the formal structure of the military and War Department, yet working in tandem, this order created a unique and new relationship in the history of the federal government. Conflict between the Commission and the war effort would be common, but from this point forward this unique organization held a role in the evolution of the Union army. It existed without a clear legal identity, brought to life by the pen of the Secretary of War, and existing without any government oversight. Nor did it receive funds from any public treasury. The Commission would remain independent of the government, but intrinsically linked to the cause.

Fairly immediately the public questioned this arrangement. Vanity Fair magazine regularly published a columnist, writing under the name of 'Vanity Fair,' who offered humorous, yet insightful, views of the state of the war effort. More than once their attention turned to the existence of the Sanitary Commission and how it was expected to work in conjunction with the Medical Bureau of the army. In one piece, the author received a letter from a gentleman called 'Quid,' who ponders “what is the function and utility of the Medical Bureau at Washington? And what is the purpose and vocation of the sanitary commission? Are they not precisely and perpendicularly one and the same?"15 Undoubtedly others wondered the same, and more to the point, 'Quid'

14 Stille, 64.

15 "Notes and Queries," Vanity Fair, Nov. 16, 1861. Accessed via "Illustrated Civil War Newspapers and Magazines." 
continues, "If the Medical Bureau is competent to take care of the health of the army, what is the need of the Sanitary Commission." 16 "Vanity Fair,' representing a reoccurring sentiment of the time, responded that "Everybody admits that the Sanitary Commission has done a great deal of good. Somebody has much doubt, therefore, whether the present Medical Bureau has done any good at all."17 Vanity Fair noted in an article, "Medical Red Tape," that the problems with the Medical Bureau were numerous, and offered a pointed example. "In Cincinnati, we noticed this week, seven physicians of that city offered their services gratuitously to the hospitals, containing four hundred sick soldiers... and were refused by the Army Surgeon in attendance."18 Additionally, "extra hospital accommodations were also offered by the citizens, and although much needed, were rejected." 19 The author turns then to the issue of the commission, encouraging them to continue in their mission: "We hope the Sanitary Commission will continue to knock at the doors of the War Department until they succeed in placing at the head of the Medical Bureau, a man who fully up to the time and whose ideas are not bounded by the hitherto narrow requirements of that office." ${ }^{20}$ Clearly, the concern of the public was not that the Sanitary Commission existed, but that it was needed.

'Vanity Fair' was not done with the Sanitary Commission. In a second examination of the commission's relationship with the Medical Bureau, the author divulged that "formerly, [I] wondered what the business of a Sanitary Commission could

16 Ibid.

17 Ibid.

18 "Medical Red Tape," Vanity Fair, Nov. 2, 1861. Accessed via "Illustrated Civil War Newspapers and Magazines."

${ }^{19}$ Ibid.

${ }^{20}$ Ibid. 
be that was not more imperatively the business of some portion, new or old, of the regular medical staff."21 "Then Vanity Fair was green," he admits. When discussions in newspapers and magazines turned to the unique arrangement between the Sanitary Commission and the Medical Bureau, the opinion held by Vanity Fair, both the author and the magazine, are the norm. In fact, the only criticism that could be located in writing about the Sanitary Commission came from southerners, who took issue with how the organization characterized the treatment of Union prisoners of war - a point of view certainly sustained by later scholarship. ${ }^{22}$ 'Vanity Fair,' for their flippant approach to the subject, echoed the widely held opinion of the Sanitary Commission when they wondered "more than it did when it knew little or nothing of the tremendous work which has this been done." ${ }^{23}$ Realizing that he had been both uninformed and naïve, 'Vanity Fair' "wonders, now, at this frightful suffering and danger which our brave men have so narrowly escaped, under the sheltering arm of a Volunteer Philanthropy."24 This volunteer philanthropy, as he words it, being important as it was "untrammeled by authority and guided by a skill and ever-thoughtful energy...not born of a bureau." 25 'Vanity Fair' was clearly impressed with the competence, energy, and organization of the Sanitary Commission - something that seemed magical to so many, but was in reality

21 “About Hygiene," Vanity Fair, Oct. 26, 1861. Accessed via "Illustrated Civil War Newspapers and Magazines."

${ }^{22}$ For examples of southern criticism of the Sanitary Commission's account of the treatment of prisoners, see: "Treatment of Federal Prisoners," The Index (reprinted from the Richmond Whig), July 15, 1865; "Prisoners of War. Letter from Mr. Mason," The Index, Feb 2., 1865;

23 “About Hygiene," Vanity Fair, Oct. 26, 1861. Accessed via "Illustrated Civil War Newspapers and Magazines."

${ }^{24}$ Ibid.

${ }^{25}$ Ibid. 
much harder to conjure. The true magic was in selecting the General Secretary of the Sanitary Commission, who imbued the mundane needs of logistics and organizational governance with the zeal of an artist.

Upon his appointment shortly after the creation of the Commission, Fredrick Law Olmsted sprung into action and joined the Union army on its way to defeat at Bull Run. Prior to the battle it became clear to Olmsted that the mission of the organization would be vital to Union success; the war effort was, even before the first battle, in disarray. In a letter to his wife, Mary, Olmsted explored the challenges before the army and the Commission: "I do not get on very well; do not accomplish much and shall not I fear."26 He began by expressing his frustrations with the officers of the Medical Bureau assigned to work with the Commission, explaining that they "cannot be seen at an average expense of less than five hours and it is hard to get their pretense of attention for five second when you get access to them." 27 Even with some access to the men, Olmsted found that "they do nothing but discourage and obstruct." ${ }^{, 28}$ After spending time observing the army, he determined that "the official machinery is utterly and absurdly inadequate for the emergency and there is no time to think of enlarging it." ${ }^{29}$ Pessimistically, in reviewing not just the camp but also the entire army, Olmsted offered that he "should not be surprised to get up and find Jeff Davis in the White House." 30 And reflecting on his own role in the disaster in the making declares, "I am inclined to regret at present that I

\footnotetext{
${ }^{26}$ Olmsted, “Olmsted to Mary Perkins Olmsted, July 2nd, 1861,” 125.

${ }^{27}$ Ibid.

${ }^{28}$ Ibid.

${ }^{29}$ Ibid.

${ }^{30}$ Ibid.
} 
accepted the post. ${ }^{{ }^{31}}$ While defeat waited in the army's future, the Battle of Bull Run provided the Commission, and Olmsted in particular, with an initial chance to define their work.

The General Secretary wasted no time in organizing a response, and while he reported feeling overwhelmed, continued to make inroads. He described the difficulties in some detail in a letter to his father, acknowledging, “...the field enlarges, to this time, so rapidly that no systems hold adequate from day to day." ${ }^{32}$ Certainly manpower was not a challenge as he was able to dispatch several men to a number of different columns of the routed army. Nor were supplies, reporting that they held “.... a stock of hospital stores more than sufficient for the present. More than 200 tons of ice. Several casks of spirits and wine." ${ }^{33}$ His problem was not manpower, or supplies, but rather determining how best to leverage the commission's assets in support of the war effort. The first step, in Olmsted's estimation, was to better understand what led to the defeat at Bull Run.

To do this he undertook to gather as much information as possible about the condition of the troops before, during, and following the engagement. With quantification as the goal - rather than collecting sentiment and impressions - Olmsted utilized his staff, in particular Ezekiel Elliot, a statistician by training, to produce a compendium of information. Their findings were telling. Most of the regiments had their last meal the evening before the battle. To get to the battlefield most marched two to four miles. One unit marched as many as twelve. Fifteen made the last mile and a half to three miles' march at the double quick. The officers of twelve regiments reported being 'much

\footnotetext{
31 Olmsted, 126.

${ }^{32}$ Olmsted, "Olmsted to John Olmsted, August $3^{\text {rd }}, 1861$," 139.

33 Ibid., 139-140.
} 
exhausted' by the beginning of the battle. Many attributed that to a lack of food, water, and having travelled too far. The list of facts and figures goes on and on, all for the purpose of better understanding the decisions and conditions that went into the defeat. ${ }^{34}$ While these statistics were made available for public consumption, Olmsted included an unpublished portion of his report just for the Board of Directors. It was clear to him that the real challenge faced by the Union Army was that the troops being relied upon were volunteers and not regulars, but the army insisted on treating them as if they were professionals. He provided specific suggestions, which were transmitted to the War Department. The impact of that report is unknown. But it became clear at that point that the Sanitary Commission would need to take steps to support a volunteer army, which had much different needs from the professional army they imagined at the outset. The organization would need to quickly transition into providing more support for the emotional needs of the soldiers rather than just advising on camp conditions and providing emergency medical supplies. Letters home would be every bit as important to the war effort as proper diet. ${ }^{35}$ That would require a significant influx of cash.

For Olmsted, a national organization working in league with the national government was not just about drawing funds from the entire nation, but also aid coming from the commission, a national entity, instead of a particular locale. As he struggled to enforce this philosophy as the war went on, Olmsted's letters reflect exhaustion. Which is probably what led to a ridiculous exchange with Bellows regarding lemons.

\footnotetext{
${ }^{34}$ Olmsted, "Report of the Demoralization of the Volunteers, September $5^{\text {th }}$, $1861, " 154-157$.

${ }^{35}$ Ibid., 170-171.
} 
Like many a nonprofit leader since, Olmsted was constantly working to manage both his board and his paid staff, and no one caused him as many problems as the independently minded Secretary of the Western District of the Commission, John S. Newberry. Of particular irritation to Olmsted was a letter written to Daniel S. Carpenter of the New York Metropolitan Police Department from Newberry, thanking the department for a donation of fifty boxes of lemons for the soldiers sieging Vicksburg. Transporting the lemons from New York to Vicksburg - which fell on the Commission as part of the donation - came at great expense, and ran counter to the policy Olmsted worked hard to establish over the course of the war. In a blistering letter to Bellows, Olmsted exclaims "you cannot have the smallest conception, I fear, of the perfect tempest of feeling which I have to bear up against, when I read such a stupid, savage folly as Newberry's letter to Carpenter." 36 Olmsted asks Bellows to place himself in the position of having no association with the Sanitary Commission, and then reading a letter in the paper explaining that the Commission's agent had trouble locating lemons for the troops. This, in spite of the fact that Newberry did not submit a request to the central office, where literal tons of lemons were on hand and available to be transported to Vicksburg through established channels. Whom, Olmsted asks, should an unassociated fellow contribute funds to should he wish to support the relief effort? The Sanitary Commission, which was unable to find lemons for the sick and malnourished men surrounding Vicksburg? Or the New York Metropolitan Police which did? Olmsted sarcastically offers "If it had not been for the singular wisdom of the Metropolitan police and the singular energy which overcame, in its struggle for humanity, even the Alleghany

${ }^{36}$ Olmsted, “Olmsted to Bellows, July 25 $5^{\text {th }}, 1863$,” 669. 
Mountains, there was no earthly hope for lemons for Dr. Newberry..."37 From Olmsted's irritated perspective, in order for the work of the Commission to be truly efficient and consistent - or in other words, organized by a corporate culture - support had to flow in from throughout the country, without special recognition or honor for anywhere in particular, and then flow out, without concern for regional origin, according only to need. The Sanitary Commission, under this system, was no longer a charity, but instead a high functioning system. A fact Newberry was struggling with grasping.

As the needs of the Sanitary Commission grew, and operations became more complex, yet systematic, the associational state was born - not in World War I as Hawley assumed - but in the mind of Frederick Law Olmsted. In the needs of the Commission he was faced with a task much larger than he anticipated, and he began to create an ideology to fit the task. What would be needed of the Commission would be monumental, and took place throughout the United States: from Virginia to Vicksburg; the Islands of South Carolina to St. Louis. A national field of operation required a truly national organization. He transformed the Sanitary Commission from a largely regional interest into the first nonprofit corporation, emphasis on the corporate nature of the organization. As the federal government became a truly national government to meet the challenge of the war, the Sanitary Commission became a corporate system, national in scope, in order to be a corollary to the war effort. Further evidence of this can be found in the answer to the question of where the organization's funds would emanate.

${ }^{37}$ Olmsted, “Olmsted to Bellows, July 25 $5^{\text {th }}, 1863$, ,., 671. 
In the first six months of the Commission's operations Olmsted was able to meet their needs with less than $\$ 5,000$ per month. The next six months, however, brought a massive influx of donated supplies to the organization, which increased costs for a wide range of expenses, from payroll to storage to transportation. With each success meeting the needs of the soldiers they witnessed an increase in demand for their services. Operations soon outpaced fundraising. Although the Commission was able to draw small gifts from all over the loyal states - and an occasional gift from supporters in Confederate states - by the fall of 1862 the Commission's coffers neared empty . Without warning, the answer to their problem arrived from an unlikely location: California. Unionist on the west coast, feeling separated from the conflict but still wanting to contribute, canvassed the state collecting donations, which were transferred to the commission in October. Bellows, wanting to praise the efforts of California, but also inspire other states, sent a telegram that was quickly published in newspapers from coast-to-coast. "Your magnificent contribution will electrify the world!" 38 He continues, "Thanks to God and to San Francisco for such unparalleled generosity. We shall make equitable distribution of your bounty." 39 The donation immediately impacted the troops, "It will be staunching wounds and cooling fevered lips before this reaches you! On the strength of it, I telegraph our agents to spare nothing on the battlefields of Maryland and Virginia, where we are disbursing hospital stores at the rate of five army wagons loads per day." ${ }^{40}$ Implicit as it was already, Bellows made explicit what he expected of other communities: "Your

38 "Munificent Contribution from San Francisco," The Scientific American, Oct. 4, 1862. Accessed via "Illustrated Civil War Newspapers and Magazines."

${ }^{39}$ Ibid.

40 Ibid. 
example will reanimate all our cities and towns. We shall lack nothing from New York, Boston, Philadelphia, Cincinnati, St. Louis, Chicago, when their already noble example is outstripped at a bound by the youngest great city in the nation." 41 To keep the Sanitary Commission solvent, even more funds would be necessary. The initial $\$ 100,000$ donation from California was quickly followed by another for $\$ 140,000 .{ }^{42}$ For the remainder of the war the board of the commission found that they could tap into the sentiment of Californians as needed. By the end of the war, the Sanitary Commission received more than $\$ 1,000,000$ from California alone. ${ }^{43}$

Bellow's intent in circulating his telegram throughout the nation's newspapers to inspire more giving from locations other than California - immediately paid dividends. Newspapers regularly carried stories of gifts given from the local community to the benefit of the Sanitary Commission. While it would be possible to fill pages and pages with such examples, a handful will prove illustrative. In Baltimore, John P. Kennedy and Alexander Bliss created a book containing facsimiles of famous authors autographs, accompanied with a selection of their writing, with all proceeds going to the Sanitary Commission. ${ }^{44}$ In Virginia City, Nevada $\$ 25,000$ was collected for the Sanitary Commission in $1862 .{ }^{45}$ At the Cooper Institute the performers of "Mrs. Z. R. Plumb's Gymnasium" put on a show for the benefit of the Sanitary Commission. "All admirers of good gymnastics should attend this entertainment," with tickets starting at fifty cents for

${ }^{41}$ Ibid.

${ }^{42}$ Stille, 198-201.

43 Ibid., 241.

44 “Autograph Leaves," Harper's Weekly, May 28, 1864. Accessed via "Illustrated Civil War Newspapers and Magazines."

45 “Epitome of the Week," Frank Leslie's Illustrated Newspaper, Dec. 13, 1862. Accessed via "Illustrated Civil War Newspapers and Magazines." 
general admission and one dollar for a reserved seat. ${ }^{46}$ Also at the Cooper Institute, at the same time as the gymnastics performance, the sophomore class held an exhibition for the benefit of the Commission. "The student of said class will have used their utmost exertions to accomplish their design of securing the interest of the public to this worthy cause," with the program featuring “... some very interesting selections from the most noted authors, and will, no doubt, afford a pleasing entertainment for the audience." ${ }^{47}$ The exhibition, we are told, was a great success, but that the author “...must not forget to enter our protest against such terrible prose as the oration on the 'Progress of Civilization. ${ }^{" 48}$ Perhaps entertainment for the sake of the Sanitary Commission was so commonplace that even do-gooding college students could not escape critic.

There are even mentions of donations coming from Europe. Without solicitation, and quite unexpectedly, a wealthy Englishman, George Elliot of London, donated 1,000 tons of coal for the benefit of the Sanitary Commission. ${ }^{49}$ Americans living in Paris during the conflict occasionally organized themselves for charitable purposes, to the benefit of the commission. In 1864 "a concert was given in the Chapel of the Rue de Berry in aid of this fund, at which the performers will be all amateurs and all

46 “Epitome of the Week," Frank Leslie's Illustrated Newspaper, Mar. 26, 1864. Accessed via "Illustrated Civil War Newspapers and Magazines."

${ }^{47}$ Ibid.

48 “Epitome of the Week," Frank Leslie's Illustrated Newspaper, Apr. 9, 1864. Accessed via "Illustrated Civil War Newspapers and Magazines."

49 "Untitled," The Scientific American, Mar. 5, 1865. Accessed via "Illustrated Civil War Newspapers and Magazines." 
Americans. ${ }^{" 50}$ It is reported that the concert and other efforts in Paris raised \$7,000 for the commission. ${ }^{51}$

While Bellow's was hoping to encourage more giving beyond California, the Golden State once again set a trend. In what became commonplace at local fundraisers, and remains a fundraising gimmick used by nonprofit organizations into the present, California introduced the "Sanitary Sack." A humble sack of flour was put up for auction and once sold, would be sold again and again all at the same event. This tradition began at a fundraiser in Nevada, California, where it changed hands twenty times, garnering $\$ 165,000$ for the Sanitary Commission. Wanting to inspire additional giving, this mundane sack of floor was transported to the Merchant's Exchange of St. Louis, where it generated another $\$ 3,775$. Last heard from, the sack was on its way to New York City. ${ }^{52}$

Not entirely common, but not unheard of, Southerners occasionally found ways to support the Sanitary Commission. Though by this point occupied by federal troops, "Varieties Theatre of New Orleans" produced a show for the benefit of the commission. All told, they raised $\$ 2,052 .{ }^{53}$ In what has to be one of the oddest episodes in raising money for the organization is the story of a wedding that took place New York City in 1864. The bride, a resident of the city, fell in love with a Southerner prior to war, who joined the Confederate army when hostilities commenced, and was since captured. "The young lady is intensely Union, but also intensely in love, and has through influence got

50 “Army and Navy Items," Harper's Weekly, Jan. 23, 1864. Accessed via "Illustrated Civil War Newspapers and Magazines."

${ }^{51}$ Army and Navy Items.

52 “Domestic Intelligence," Harper's Weekly, Feb. 18, 1864. Accessed via "Illustrated Civil War Newspapers and Magazines."

53 "Literary and Art Gossip," New York Illustrated News, Jun. 4, 1864. Accessed via "Illustrated Civil War Newspapers and Magazines." 
permission from the powers that be to take her rebellious admirer out of his cage for a week or two just long enough to marry him." ${ }^{n 4}$ As part of the agreement, guests at the wedding were expected to pay a three dollar admission price, with all funds collected going to the Sanitary Commission. ${ }^{55}$

Cash, obviously being the most liquid and flexible of donation types, was not the only thing accepted by the organization. The Sanitary Commission collected untold amounts of goods, homemade and factory produced alike. The people of Pokagon, Michigan, "but a cluster of some twenty houses," pulled together a disproportionately large donation of "forty-nine barrels of pickled potatoes, cabbage, and other pickles, and thirty-three bushels of potatoes in bulk." 56 In Manchester, Connecticut, a nine year old named Grace L. Bissel went "among the little girls and boys soliciting blocks for a soldier's bed quilt, with name of the child inscribed thereon." ${ }^{\prime 57}$ When the quilt was completed, she sent it off the Sanitary Commission, but first writing a letter to the solder who would receive it, asking for him to write her back so she could remember him in her prayers. After completing the first, she went again seeking contributions, and within two months was able to send a total of six quilts to the soldiers. ${ }^{58}$ Messages accompanying donated items were not uncommon. An article from 1864 references a number of items carrying sentiments to the front. A blanket with a piece of paper pinned to it stating "This

54 “Town Gossip," Frank Leslie's Illustrated Newspaper, May 7, 1864. Accessed via "Illustrated Civil War Newspapers and Magazines."

${ }^{55}$ Ibid.

56 “All Sorts Things," New York Illustrated News, Apr. 20, 1864. Accessed via "Illustrated Civil War Newspapers and Magazines."

57 “A Noble Little Girl,” New York Illustrated News, Mar. 19, 1864. Accessed via "Illustrated Civil War Newspapers and Magazines."

${ }^{58}$ Ibid. 
blanket was carried by Milly Aldrich (who is 93 years old) down hill and up hill, one and a half miles, to be given to some soldier."59 A pillow, informing the receiver that it “...belonged to my little boy, who died resting on it: it is a precious treasure to me, but I give it for the soldiers." ${ }^{\prime 60}$ Homemade bandages accompanied with the message, "This is a poor gift, but it is all I had; I have given my husband and my boy, and only wish I had more to give." ${ }^{61}$ The impact of the commission, and the commitment to support it, is evident in communities all throughout the United States.

Solicitations from the Sanitary Commission to the people for funds were common, as were requests for particular items. The needs were often various and hard to quantify, but on occasion the opportunity to ask for a particular homemade item came to the forefront. One such occasion, in 1863, presented itself in the face of a serious outbreak of dysentery. The commission at the time believed that one of the best cures for that particular infliction was rhubarb wine. In their call for donations, they included a recipe to aid in the production of quality homemade product: "Peel and slice the stock of the leaf as for pies; put a very small quantity in the vessel, only just enough to cover the bottom; cover the vessel and gradually bring to a boil; then strain, pressing out all the liquid." ${ }^{2}$ The recipe calls for an equal part water to be added to the strained by-product, "add four to five pounds of brown sugar, set aside, ferment and skim like currant wine: leave in the cask and in bulk as long as possible before sending away. All wine is better

59 "Marked Articles for the Soldiers," The Scientific American, Apr. 9, 1864. Accessed via "Illustrated Civil War Newspapers and Magazines."

60 Ibid.

${ }^{61}$ Ibid.

62 "Rhubarb Wine for Sick Soldiers," The Scientific American, Jun. 6, 1863. Accessed via "Illustrated Civil War Newspapers and Magazines." 
kept in casks." ${ }^{\prime 3}$ There is no follow up article indicating the response to the request (but the recipe does seem relatively simple).

California held a special place in the financial stability of the Sanitary Commission, but second to it were the various 'sanitary fairs' that took place throughout the country. Each city or state that undertook a fair - and it appears that those were about any place of note - utilized their own methods for raising money, based on the population and wealth of the host community, and their creativity. Two fairs, located in the same city, are illustrative of the range of activities. Brooklyn, wanting to spend a moment in the sun, and "not to be outdone by other cities in the land," decided in 1864 to organize a fair of its own. ${ }^{64}$ This fair, offered to attendees a marvel new to sanitary fairs: "The New England Kitchen." ${ }^{5}$ The article relaying the details of the fair continues, "The idea is to present a faithful picture of New England farmhouse life of the last century. The grand old fireplace shall glow again, the spinning wheel shall whirl as of old, the walls will be furnished with the products of the forest and the field." 66 The author, aware of the image being conjured, encouraged interested parties to attend, commenting that "the room will be of ample size for the accommodation of a large number of guests, for whose entertainment the best of materials, cooked in the best manner, will be served during the continuance of the fair." ${ }^{97}$ Nostalgia, though not so authentic as to be cramped, drew forth visitors looking for a simpler time, before the nation was embroiled in conflict.

${ }^{63}$ Ibid.

64 “The Sanitary Fair at Brooklyn,” Frank Leslie's Illustrated Newspaper, Mar. 5, 1864. Accessed via "Illustrated Civil War Newspapers and Magazines."

${ }^{65}$ Ibid.

${ }^{66}$ Ibid.

${ }^{67}$ Ibid. 
In the same year, New York City proper hosted what by this time became a yearly affair, the Metropolitan Sanitary Fair. Unlike the quaint feel of the New England farmhouse presented by Brooklyn, this fair was a massive ordeal, "which for a fortnight had engaged the attention of all New York and it environs. In every respect the Fair has been a success, and thousands of our brave defenders in the field, in days of suffering, in camp and hospital, will gather benefits from the munificent charity..."68 As the ultimate purpose of all the fairs was to generate as much revenue as possible from the spectators, the Metropolitan Fair collected donated items from a number of the city's purveyors and collectors, resulting in all manner of items available for purchase. All proceeds, of course, going to the support of the Sanitary Commission. Bibliophiles could visit the 'Book Department.' Sailing enthusiast would be drawn to the 'Boat-Building Department.' Armchair historians found all sorts of collectibles in the 'Department of Arms and Trophies.' Much like the Brooklyn fair, even the Metropolitan Fair felt the need to offer a unique attraction - which was a quite odd choice. The fair stretched across several buildings in a few block radius; but visitors to the Fourteenth Street building encountered the prime entertainment of the event. The building, an observer informs us, "has been constantly crowded by visitors desiring to study the habits and peculiarities of the aborigines. Several entertainments have been given daily by our Indians." 69 The author continues, "Historically, no feature of the Fair has greater interest that this in which the life of those who, only a little while ago, held undisputed possession of our

68 “Sketches of the Metropolitan Fair," Harper's Weekly, Apr. 23, 1864. Accessed via "Illustrated Civil War Newspapers and Magazines."

${ }^{69}$ Ibid. 
continent..."70 The literal consumption of goods, and the figurative consumption of the other, for the benefit of the Sanitary Commission, was viewed only as a positive. "And tens of thousands who are to-day preparing for the shock of conflict will carry themselves with a grander heroism and robust faith, in the white heat of battle," the author assures their readers, "because of the assurance this Fair gives that the people at home remember and care for the soldier, and delight to soften the rough places of his experience." 71 Although its purposes were valuable, needed, and humane, it is clear that the Sanitary Commission, via sanitary fairs, inserted themselves into the market economy, and took advantage of the emerging American fascination with consumption.

The impact of the fairs was significant. In 1864 alone, Chicago, Boston, Cincinnati, Albany, Brooklyn, Cleveland, and Buffalo all held fairs, resulting in $\$ 1,002,000$ raised on behalf of the Sanitary Commission..$^{72}$ This is not to mention countless other fairs held throughout the country, most notably in St. Louis. ${ }^{73}$ The Metropolitan Fair held in New York that year was expected to generate more than $\$ 1,000,000$ alone. At final count it exceeded $\$ 1,200,000 .{ }^{74}$ California remained the driver of the Sanitary Commission's financial stability, these fairs provided needed additional funds. By the end of the war, the commission was unable to provide a solid final revenue

\footnotetext{
70 Ibid.

${ }^{71}$ Ibid.

72 "Miscellaneous Summary," The Scientific American, Apr. 9, 1864. Accessed via "Illustrated Civil War Newspapers and Magazines."

73 “Mississippi Valley Sanitary Fair," Harper's Weekly, May 14, 1864. Accessed via "Illustrated Civil War Newspapers and Magazines."

74 "Inauguration of the Central Sanitary Fair, Philadelphia," Frank Leslie's Illustrated Newspaper, June 25, 1864. Accessed via "Illustrated Civil War Newspapers and Magazines.”
} 
figure, they estimated that its total revenue exceeded $\$ 15,000,000 .{ }^{75}$ The equivalent of around $\$ 300,000,000$ in 2016 dollars. $^{76}$

The generation of so much revenue demonstrates the degree to which Americans felt the Sanitary Commission was a legitimate cause in which to invest their dollars. The cultural impact of this new organization's sudden appearance in the American landscape was striking. The Sanitary Commission, in deeds, in name, and in cultural influence, was everywhere. Harpers Weekly occasionally included images of the Sanitary Commission agents at work in the field in its editions. ${ }^{77}$ Frank Leslie's Illustrated Newspaper did the same. ${ }^{78}$ While Frederick Law Olmsted toiled in frustration and constant administrative roadblocks, Bellows became a national icon. His image, drawn in stately determination, regularly graced the pages of Americas newspapers and magazines, most notably Frank Leslie's Illustrated Newspaper. ${ }^{79}$

The Sanitary Commission even inspired works of poetry. F. B. Haste, reflecting on the initial gift to the commission from California, composed a six stanza piece

75 Stille., 478.

76 This calculation is from the website Measuringworth.com. Other websites that calculate inflation were referenced, with results ranging from around $\$ 200,000,000$ to more than one billion dollars. The results from this website seemed a good average.

${ }^{77}$ As an example, see "Building of the Northwestern Sanitary Commission and Soldiers' Home," Harper's Weekly, June 17, 1865. Accessed via “Illustrated Civil War Newspapers and Magazines."

${ }^{78}$ As an example, see the cover of Frank Leslie's Illustrated Newspaper, Apr. 9, 1864. Accessed via "Illustrated Civil War Newspapers and Magazines."

${ }^{79}$ As an example, see "Dr. Henry W. Bellows of New York," Frank Leslie's Illustrated Newspaper, Apr. 16, 1864. Accessed via "Illustrated Civil War Newspapers and Magazines." 
capturing the sentiment of those so far from the fighting. After reviewing the challenges facing the nation, Haste opined:

"Oh, brother by the further sea,

Think still our faith is warm;

The same bright flag above us waves

That swathed our baby form. "80

For Californians, as evidenced in the size of their donations and this poem, even though the conflict was happening on the other side of the continent, still felt pangs of patriotism and wanted to contribute to the effort. A similar sentiment seems to have been generated for Northerners, reading the (controversial in the south) report of the treatment of prisoners of war. An unattributed poem, eight stanzas in length, creates a vision of their suffering for the reader,

"I see their bony fingers spread in vain

For one sweet morsel - spread in vain to take

The dear home letter - or to still retain

The trinkets sacred for love's tender sake." 81

Unable to take direct action, the poet expressed his despair in a poem - an artist, in the moment, wholly inspired by the work of the Sanitary Commission. Most illustrative,

80 “Our Privilege,” Frank Leslie's Illustrated Newspaper, Dec. 6, 1862. Accessed via "Illustrated Civil War Newspapers and Magazines."

81 “Barbarism," Harper's Weekly, Dec. 24, 1864. Accessed via "Illustrated Civil War Newspapers and Magazines." 
however, is the degree to which others attempted to coopt the reputation of the commission.

Advertisements leaning on the good works of the Sanitary Commission appeared regularly in Civil War publications. Dr. G.W. Scollay spent what must have been a small fortune advertising his "Air-Tight Deodorizing Burial Case. ${ }^{92} \mathrm{He}$ assured his readers that "When the invention was completed, and its efficacy tested by numerous experiments...he brought it before the Western Sanitary Commission of St. Louis." ${ }^{93}$ After their own extensive examination of the product, they determined that it was in fact air tight, but users did not have to fear explosion from gases thanks to an adjusting valve system. "We regard it as our duty," the commission's report is to have claimed, "in the present exigency to bring it speedily before the public, and recommend its general adoption." ${ }^{" 4}$ Considering the lack of corroborating evidence elsewhere, these claims appear less than authentic. Another such example can be found in machines produced by Munn \& Co. of Kentucky. In their repeated advertisements, they assure potential consumer that the the Sanitary Commission directed the Kentucky branch of the organization to "present you their grateful thanks for your prompt, kind, and considerate attention to their request for information on the subject of a knitting machine." ${ }^{95}$ The marketing piece continues, "You not only responded to the request, but you have gone beyond all we asked in purchasing a machine far below the selling price, and in promptly

${ }^{82}$ As an example, see "Dr. G. W. Scollay's," The Scientific American, Feb. 28, 1863. Accessed via "Illustrated Civil War Newspapers and Magazines."

83 Ibid.

84 Ibid.

85 "A Complimentary Letter from the Kentucky Sanitary Commission," The Scientific American, Jan. 31, 1863. Accessed via "Illustrated Civil War Newspapers and Magazines." 
forwarding it to us. It reached here in good order..." 86 The implicit message, of course, is that if this machine is good enough for the Sanitary Commission, who must rely on it to support the troops, it is good enough for the average home. Assuming that the machine actually worked, there was at least some value to those duped by the erroneous association with the commission.

That was not the case with the ubiquitous advertisements for 'Brandreth's Pills.' In this advertisement, sixty members of Company F, of the Seventeenth New York State Volunteers, claimed that their "constitutions were uninjured by the necessary hardships and privations of a soldier's life in the field." ${ }^{87}$ It was their experience that the pills cured, if taken within the first few days of contracting, "colds, chills, diarrhea, dysentery, and typhoid fever." ${ }^{\prime 8}$ I. William Skinner, a notary public in New York, certified that all sixty men did in fact sign their statement on behalf of the pills. And I. Hiram P. Rowel, Clerk of the County, certifies that Skinner did in fact sign his statement that the sixty volunteers signed their statements. Unique from some of the other examples, however, Bandrith's Pills primarily aimed its marketing efforts at the Sanitary Commission: "Let the following testimony from the sixty returned volunteers be studied by members of the United States Sanitary Commission. If these statement are true," the advertisement ponders, "can they be doing their duty as Christian Men in not using the means Providence has placed within their reach?" 89 As no other mention of 'Bandrith's Pills'

\section{Ibid.}

${ }^{87}$ As an example see "United States Sanitary Commission," Harper's Weekly, Feb. 6, 1864. Accessed via "Illustrated Civil War Newspapers and Magazines."

${ }^{88}$ Ibid.

${ }^{89}$ Ibid. 
appears elsewhere in the historical record, the Sanitary Commission may be excused for not pursuing use of this wonder drug.

Regardless of the good works of the Sanitary Commission, or the amazing record of fundraising, or the national impact, or the application of corporatist culture within a charity by a zealous administrator, or the cultural impact that inspired both poets and cheats - in this first nonprofit corporation is something new, a unique organization, an experiment that redefined the relationship between private charity and government. In this proto associational state experiment there must have been someone, somewhere, who objected to this transfer of the state's responsibility to a non-governmental agency. But there is no record of any criticism of the government accepting an independent organization into the war effort at all. In fact, commenters overwhelmingly viewed the creation and activity of the Sanitary Commission as a public good, working toward a humane end, and extending, rather than obstructing, republican institutions.

For The Scientific American, the issue was one of practicality. "There is no one element of more importance to the efficiency of the army than its sanitary condition." 90 When illness occurs, the author argued, there is a cost in military efficiency, a cost to those who must carry on without him, and a cost to the taxpayer: "It is estimated that each soldier costs the government $\$ 1,000$ per year, and of course on all that are ill not only is the expense lost, but an additional cost in taking care of them." 91 Though this article does not consider where the funds for the Sanitary Commission are to be found, it

90 "The Condition of our Soldiers," The Scientific American, Nov. 9, 1861. Accessed via "Illustrated Civil War Newspapers and Magazines."

${ }^{91}$ Ibid. 
comments that it is “... acting under government sanctions, have been devoting special attention to the condition of the hospitals and the comfort of our sick and wounded soldiers, but have no appropriation from Congress..."92 This fact was widely viewed as a positive in evaluating the work of the organization. In the estimation of Harper's Weekly columnist 'The Lounger,' the financial independence of the organization was ideal: "For many evident reasons the Commission prefers to appeal directly to the public and not to Congress. ${ }^{" 93}$ Evident to the writer and his readers perhaps, but less so to the historian. To dive deeper into 'The Loungers' perspective, what made the Sanitary Commission uniquely effective at meeting its mission was its independence from the government independent, but still with access. "The Surgeon-General of the Army has given it full authority to inspect and examine all posts, camps, and hospitals; and the Secretary of War has ordered all person in Government service shall assist the commission to the utmost." ${ }^{\text {" For }}$ 'The Lounger,' financial independence, while having access to the bureaucracy of the war effort, left the Sanitary Commission free to do what was right and necessary, without being beholden to any particular interest. Leading to his declaration that "There is no department of service in the war that will be more beneficial than this..."95

As would become typical of large nonprofit corporations, as the war dragged on, and the donations to the commission increased exponentially, some began to wonder where the funds went. But unlike countless contemporary organizations - the Red Cross

\section{Ibid.}

93 “The Lounger," Harper's Weekly, July 6, 1861. Accessed via "Illustrated Civil War Newspapers and Magazines."

${ }^{94}$ Ibid.

${ }^{95}$ Ibid. 
most prominently - the financial independence of the Sanitary Commission seems to have rescued it from criticism in the press. Instead, the press actively pushed the agenda of the organization by consistently defending it from any such allegations of financial mismanagement. As early as 1862, Harper's Weekly, via “The Lounger,' responded to the possibility that some may ponder the distribution of the organization's bounty: “And let it be remembered that the longer the war lasts the more stringent is the demands for every kind of supply that has been hitherto furnished to the Commission." 96 Furthermore, even "The most skeptical now see and confess its great service to the life and health of the army. Its operations, although in conformity to the military departments, are yet carried on independently." 97 Again, from 'The Lounger's' perspective, independence was key to the commissions' success and trustworthiness. He offered Antietam as a case in point, in which the supplies of the commission arrived "...forty-eight hours before those of the regular Government authorities; and its traveling hospital and pharmacy and sick commissariat moves in the van of the army." 98 In his estimation, rather than being a point of concern for citizens, "The Sanitary Commission is an illustration of the results attainable by the direct application of common sense to the emergency." Their conduct, rather than bringing forth criticism, earned praise.

The editors of the Continental Monthly expressed a similar sentiment. In an exploration of a forthcoming sanitary fair, they posed the all important question: "Why

96 “The Lounger," Harper's Weekly, Dec. 27, 1862. Accessed via “Illustrated Civil War Newspapers and Magazines."

${ }^{97}$ Ibid.

98 Ibid. 
does the Sanitary Commission need so much money?"99 Before going into minute detail of the organizations works, they offered a comprehensive and direct answer. "Because the present machinery of the Commission, supported by the Central Treasury [of the organization, not the federal government] cannot be kept in motion without large expenditures; and large as the cost is, the results for good are almost infinitely larger." 100 For a columnist at Frank Leslie's Illustrated Newspaper, 'The Idler About Town,' any discussion of the organization's finances was moot. "It is certain that everyone will joyfully assist in so noble a cause. It has nothing to do with politics." ${ }^{101}$ He elaborated, noting "whether it be the Union, the Republican, the Peace or War Democrats, or any other stripe or party, the cause, which is charity, help and comfort to all who are suffering in the general cause, is sacred..." 102 Though he takes it as the indisputable duty of all, it is also the nature of the organization that has inspired this position, “...the importance of organizing the right kind of people to systematize that assistance is manifestly the first consideration." 103 'The Idler' recognized what made the Sanitary Commission unique in the landscape of charity - the application or corporate methods and culture to charity, rendering the commission above reproach.

An unnamed author for Harper's Weekly trod the same ground. "How is it that the Sanitary Commission spend so much money?"104 This author noted much the same as the

99 “Editors Table," Continental Monthly, March, 1864. Accessed via "Illustrated Civil War Newspapers and Magazines."

100 Ibid.

101 “The Idler About Town,” Frank Leslie's Illustrated Newspaper, Feb. 13, 1864. Accessed via "Illustrated Civil War Newspapers and Magazines."

102 Ibid.

103 Ibid.

104 “Uncle Sam's Pence," Harper's Weekly, Feb. 13, 1864. Accessed via "Illustrated Civil War Newspapers and Magazines." 
prior examples, pointing to millions expended in support of the war effort., the herculean task of easing the dying, the supplies utilized in convalescing the wounded, the sums of money saved by the federal government because of the organization's care of the soldier in camp. The conclusion reached, even more explicit than previous, is telling: "For all these purposes ready money is essential. It must be as sure an income as that of any other business, and it must last while the war lasts, or this great mercy must stop now." Without intending, this author struck upon the fundamental truth of the nonprofit corporation. It is, in its essence, a business - though it be organized for public good rather than profit - and it must, at the end of the day, have revenue in excess of expenses to continue to operate. For such a large operation, so reliant on funding to remain viable, America witnessed a new type of organization brought to life.

Those with a more philosophical than pecuniary bent reached the same conclusions. In 1865, Atlantic Monthly embedded an unnamed reporter with a contingent of Sanitary Commission agents. The events reported by the journalist echo much of what others observed of the Commission. Of particular note, however, is the conclusion drawn by the journalist about the long-term impact of the Sanitary Commission:

"And when this war is over, and the land is redeemed, and we have to ask what things have strengthened us to meet our common peril, may we not prophesy that high among the instrumentalities which have husbanded our strength, and fed our patriotism, and knit more closely the distant parts of our land and its divided interests, will be placed the United States Sanitary Commission?"105

105 "A Fortnight with the Sanitary," The Atlantic Monthly, Feb. 1865. Accessed via "Illustrated Civil War Newspapers and Magazines." 
Not explicit in his conclusion, or offering a clear vision of what it meant for the future, the author marked the Sanitary Commission as something unique in the war experience. An organization born of war, bringing national unity through charity. Others were more direct.

An article in the Boatswain's Whistle, a publication directed at sailors, specifically asked what impact the Sanitary Commission would have on republican institutions. Beginning by noting that "Nothing is given away, but everything is bought with a price. We give up one advantage that we may posses another: we sell one thing that we might procure another," the author indicates that the same is true of governments. ${ }^{106}$ It notes that "A centralized bureaucratic despotism has certain recommendations, especially the way of material development. It can organize great plans, radiating from a central point and embracing the whole territory of a country." 107 Centralization provided, according to author, specific benefits: "It can beat down local jealousies and sectional oppositions. It can command the element of time, and in this avoid the evils alike of hurry and delay." ${ }^{08}$ Even with those advantages and efficiencies, however, the author concluded that ultimately the American system of government is superior. "The value of our institutions consists in the fact that they diffuse intelligence, activity, and energy...They make men self-reliant, quick-witted, fertile in resources, and with elastic power of recuperation." ${ }^{109}$ He elaborated, "no other people have the faculties of organization and combination to such an extent as we Americans. In no other country

106 "Republican Institutions," The Boatswain's Whistle, Nov. 18, 1864. Accessed via "Illustrated Civil War Newspapers and Magazines."

${ }^{107}$ Ibid.

108 Ibid.

109 Ibid. 
do men and women so easily and so readily work together, and fall so quickly into the ranks of an association." ${ }^{110}$ While tinged in nationalistic sentiment, the author was ultimately correct: associationalism is a distinctly American trait, realized in a new type of organization beginning with the Civil War, a fact that is clear to the author. "The Sanitary Commission, which has done and is doing such a world of good, piecing out so effectually the deficiencies of our government, is that natural outgrowth of our institutions." ${ }^{111}$ Republican institutions, as the author refers to it, but more precisely civil society, would continue to grow and adapt as a result of the conflict, and in particular, the model of management and success provided by the Sanitary Commission.

In 1865 the Chief Justice of the United States Supreme Court, Salmon P. Chase, provided, as part of his chairmanship of the Freedmen's Relief Association, a review of the changes brought by the war. Though he pointed to a number of changes in American society and culture, most notably the end of slavery, the thing that stuck out to him most, were "great charities even more than...great achievements." 112 He clarified, stating:

"What age before this age, and what country besides our country, ever witnessed such an organization as that of the Sanitary Commission? What needs have been supplied; what wants relieved; what wounds healed what evils averted, by the activity, wisdom, and unflagging zeal of this admirable organization, fostered and sustained by the people, and recognized and aided by the government."113

110 Ibid.

111 Ibid.

112 "Remarks of Chief Justice Chase," The Liberator, Mar. 10, 1865. Accessed via "Illustrated Civil War Newspapers and Magazines."

113 Ibid. 
Indeed, it was unique. The government created, for the purposes of supporting a public cause, a private institution. Completely reliant on popular support for resources, it ensured the flow of funds, utilized corporate practices and culture to ensure responsible stewardship, and built public confidence. As unique as it was, the organization of the Sanitary Commission was the future of the nonprofit corporation in the United States, and provided a prototype for the coming of the associational state. 


\section{Chapter 3}

The Freedmen's Bureau

As Union armies expanded their foothold in the Confederate States throughout 1862 and 1863, their presence destabilized the slave economy in nearby communities. The slaves, inspired by the prospect of freedom, began voting with their feet and fleeing to Union encampments. Realizing that caring for people who suffered inhumane conditions, had no wealth, few if any personal possession, and little hope for employment ultimately fell to military leaders to resolve, the War Department initiated a commission to recommend a path forward. The American Freedman's Inquiry Commission sought a balance between two distinct pitfalls. With little prospect for success in the market economy in which slaves suddenly found themselves competing, some benevolent force had to assume 'guardianship' over the freed people. At the same time, there was danger in a new bureaucracy becoming permanent, and as such, paternalistic rather than protective. Into this quagmire Congress spawned the Freedmen's Bureau in March of $1865 .^{1}$

In the Bureau's initial one-year charter, it was tasked with distributing food and clothing, and addressing issues related to the general conditions of the former slaves in the South. While most recognized that this new bureaucracy could interpret its charge widely, its lack of a direct budget - instead drawing funding from the War Department to which it was merely an offshoot - was meant to provide restraint. But by the time the

${ }^{1}$ Eric Foner, Reconstruction: America's Unfinished Revolution, 1863-1877 (New York: First Perennial Classics, 2002), 68-69. 
enacting legislation escaped the halls of Congress, the Bureau's portfolio was expanded to meet other immediate needs, including displaced white migrants, and most importantly, abandoned lands. It was supervision over unworked plantations, and the rents that came with reigniting the agricultural economy of the South, that generated the revenue needed to address the needs of the former slaves. From opening schools, to encouraging voting and officeholding, to providing seed and tools to small-scale farmers, the Freedmen's Bureau became the most important social, economic, and political force in the South. ${ }^{2}$

Forty years later, W.E.B. DuBois' offered an assessment of the Freedmen's Bureau that remains correct. He contended the bureau "set going a system of free labor; it established the black peasant proprietor; it secured the recognition of black freemen before the courts of law; it founded the free public school in the South."3 The efficacy of the agency's work can be debated, as DuBois recognized, but "the most bitter attacks on the Freedmen's Bureau were aimed not so much at its conduct or policy under the law as at the necessity for any such organization at all." ${ }^{4}$ Generally, these attacks on the bureau's record served as a strawman for undermining the need for such an organization, usually directed at its leader, General Oliver Otis (O.O.) Howard. In 1870 Howard was ordered before Congress to face accusation of malfeasance, resulting in a months long trial. Found innocent of all charges, the general guided the bureau to the end of its bureaucratic life, resuming regular army duties in 1872. Coming under fire two years later, Howard

${ }^{2}$ Ibid., 68-70.

${ }^{3}$ W.E.B. DuBois, The Sociological Souls of Black Folk (Plymouth, UK: Lexington Books, 2011), 37.

${ }^{4}$ Ibid., 38. 
was court martialed for mismanagement of the bureau, but once again was found innocent. DuBois could not help but concede that "nevertheless, many unpleasant things were brought to light: the methods of transacting the business of the Bureau were faulty; several cases of defalcation among officials in the field were proven; and further frauds hinted at."5 Additionally, "there were some business transactions which savored of dangerous speculation, if not dishonesty."6 If DuBois misread one thing from his review of the bureau's troubles, it was the assertion that "it is but fair to say that the perfect honesty of purpose and unselfish devotion of General Howard have passed untarnished through the fire of criticism."7 The modern eye, however, recognizes more clearly the troubled legacy of O.O. Howard's leadership, and what the experience of the bureau meant for the federal government's role in civil society.

The Freedmen's Bureau, as conceived by Howard, was nothing short of a grand experiment - one that modern day scholars of nonprofit management will immediately recognize. Howard, in creating plenty of rumors and transactions for Congress to investigate, offered a vision of civil society in Modern America centered on two strategies. Short of resources solely controlled by the Bureau, Howard went in search of opportunities to increase discretionary revenue by utilizing social entrepreneurship: the application of an entrepreneurial approach to a social problem, generally resulting in creating a new business venture, in which profits are used to address a connected social issue. ${ }^{8}$ Recognizing that the Bureau was also short of time - a change in political winds

\footnotetext{
${ }^{5}$ Ibid.

${ }^{6}$ Ibid.

${ }^{7}$ Ibid.

${ }^{8}$ Roger L. Martin and Sally Osberg, "Social Entrepreneurship: The Case for Definition," Stanford Social Innovation Review (Spring 2007).
} 
would undoubtedly end the bureaucracy's existence - Howard took advantage of available discretionary funds to stabilize new institutions serving the Freed people; undertaking what would now be called capacity building. ${ }^{9}$ The unprecedented trail blazed by the Bureau, in which the government engaged in entrepreneurial undertakings to generate revenue, which was then used to strengthen nonprofit organizations, represented direct intervention by the government into civil society. When the charter of the Bureau was allowed to expire, this level of direct involvement by the federal government would not be attempted again until the New Deal. Much of this, however, was buried in the innerworkings of a misunderstood bureaucracy.

The Freedmen's Bureau did not advertise these efforts. The clearest window into the activity of the Bureau and Howard's leadership can be found in the transcript of his congressional trial. Weighing in at more than 500 pages, with much of the testimony focused on accounting procedures, it dives deep into the mundane day-to-day operations of the bureau. Yet, this source, let alone the events it details, has been largely ignored by historians. ${ }^{10}$ Taking the time to examine the management of the Freedmen's Bureau,

\footnotetext{
9 Jared Raynor, "The Return of Capacity Building," Stanford Social Innovation Review (Nov. 2014).

${ }^{10}$ DuBois briefly discusses it in an essay later in his career. It does not appear at all in his seminal examination of Reconstruction. It is missing from Foner's full length and abridged examination of the period. Nor does it enter the fray in the go-to examinations of Reconstruction offered by James Alex Baggett, Michael W. Fitzgerald, Heather Cox Richardson, or Mark W. Summers. Perhaps outside of the scope of their arguments, or so deep in the weeds of financial management to be worth the time to decipher it, historians have largely ignored this episode. See the following: James Alex Baggett, Scalawags: Southern Dissenters in the Civil War and Reconstruction (Baton Rouge: Louisiana State University Press, 2004); Michael W. Fitzgerald, Splendid Failure: Postwar Reconstruction in the American South (Ivan R. Dee, 2008); Heather Cox Richardson, The Death of Reconstruction: Race, Labor, and Politics in the PostCivil War North, 1865-1901 (Boston: Harvard University Press, 2004); Mark W.
} 
however, is a useful exercise - not as much for what it illustrates about the Reconstruction process, but for the potential course of civil society the bureau represented. The role the organization played in building the capacity of early nonprofit corporations was instrumental in establishing the relationship between the government and charities. In the actions of the Freedmen's Bureau a path to a government supported, prioritized, and regulated nonprofit sector emerges. A opposite path, in which the nonprofit sector would be independently financed, value freedom of mission, and operate largely without direct government oversight, emerged in the experience of the United States Sanitary Commission. With the actions of the Freedmen's Bureau coming under intense scrutiny as the urgency of the Civil War began to fade, the Federal government moved away from capacity building or directly investing in nonprofit corporations. The political challenges to such measures, left no other option. The end of the Freedmen's Bureau ensured the primacy of the independent nonprofit sector.

By 1870 , as constituents in the north became less interested in reconstructing the south and with the plight of African Americans lost focus, the Freedmen's Bureau became a political football. Acts of Congress to extend the life of the organization still passed, but its reputation withered with each debate. When Congress debated extending the Freedmen's Bureau mission - though in a reduced form - on April 1 $1^{\text {st }}, 1870$,

Summers, The Ordeal of the Reunion: A New History of Reconstruction (Chapel Hill: University of North Carolina Press, 2014). 
fireworks were predicted. Events took an unexpected turn as Representative Fernando Wood rose to speak. ${ }^{11}$

Congressman Wood was hardly a pillar of thoughtful governing. Made famous for opposing passage of the Thirteenth Amendment to the Constitution and a career of public service that refused to recognize non-white Americans as part of the public, his greatest contribution to history came with his establishment of the political machine Tammany Hall. ${ }^{12}$ The irony of America's most significant political boss rising before Congress to condemn unethical behavior was not lost on the press. ${ }^{13}$ But condemn he did. Although he claimed to have no personal knowledge of the allegations, nor hold any bias or grudge against the general, Wood presented thirteen specific charges against Howard. Most importantly, Howard was accused of syphoning more than $\$ 500,000$ from the bureau's budget to Howard University, named after the general. All of the accusations - from his misuse of bureau funds for personal use to benefitting from bureau contracting, to provide a few examples - can all be classified as financial malfeasance. ${ }^{14}$

Following three months of examination, the majority of the committee absolved General Howard of all wrongdoing, noting that "it would be unjust to the gallant officer and faithful public servant who has so honorably passed the severe ordeal to which he has been subjected, daily, during the past three months, to close this report with a simple

${ }^{11}$ Committee on Education and Labor, Charges Against General Howard (Washington, DC: House of Representatives, 1870), 1.

12 Jeremy Mushkat, Fernando Wood: A Political Biography (Kent, Ohio: Kent State University Press, 1990).

13 "Washington: Progress of the Tariff Bill - A String of Charges Against Gen. Howard - The Funding Bill - Mr. Bennett's Canal Bill - The Deficiency Bill Miscellaneous," The New York Times (Apr. 7, 1870), 1-2.

${ }^{14}$ Committee on Education and Labor, 2-3. 
verdict of acquittal." " The majority contended defended "as one of the great landmarks of political and social progress, the organization and administration of the Freedmen's Bureau."16 The minority still found much to criticize. Using rhetoric as heated and partisan as that of the majority, they maintained the bureau "had been made a mighty engine of power, by which to control an entire section of the Union, and bring it under partisan subservience," essentially through its immense budget. ${ }^{17}$ To execute this dominance, "emissaries have been dispatched to the South with the Bible in one hand, and the purse in the other, and who have been backed up and sustained by both the military and civil power of the government." ${ }^{18}$ Between the search for a wide-spread conspiracy presented by the Democrats, and the inability to find fault in any of the bureau's actions by the Republicans, it is clear that this hearing was more about partisan gain that evaluation.

The truth lay somewhere between the rhetoric. Howard, charged with an impossible task and limited resources, did far more than could have been imagined. The outcomes achieved by the bureau were truly remarkable. How the Freedmen's Bureau was able to achieve much of what it did, however, could only be classified as unethical. The methods by which Howard was able to expand the limited funds available to the bureau resembles what would today be aggressive financial management coupled with social entrepreneurship. A review of three of the significant issues explored in the hearing - the Barry Farm project, the use of distinct funds without consistent respect for their

\footnotetext{
15 Ibid., 17.

${ }^{16}$ Ibid.

${ }^{17}$ Ibid.

18 Ibid.
} 
intended purpose, the building and funding of Howard University - demonstrates the complex nature of the bureau's activities, which pointed to one potential way of organizing civil society in modern America: the path not taken.

The clearest example of the social entrepreneurship efforts of the Freedmen's Bureau came at the behest of Senator Samuel C. Pomeroy of Kansas. A long-time ally of both the Bureau and Howard's and an outspoken abolitionist, Pomeroy observed that the African American population of Washington, DC needed support. When the senator appeared before the investigating committee, he informed them that following the war there was a large population of freed people who migrated to the city, with limited access to accommodations and employment, whose living conditions were appalling. At first, under the direction of the Secretary of War, via the Freedmen's Bureau, decommissioned barracks were opened up to them, and soon more were constructed to increase available housing. But, "families were thrown promiscuously, men, women, and children, in great numbers, into those large buildings." ${ }^{\prime 19}$ The solution to this problem crafted by the leadership of the Bureau and Pomeroy became known as Barry Farm. Ahead of its time, Barry Farm became an early experiment in housing projects. Freedmen looking for a home were provided one as a rental, which with continuous payment the title transferred to the resident. This arrangement, however, seemed to many beyond the initial intent of the Bureau's mission.

${ }^{19}$ Ibid., 481. 
One of the longest interviews by the committee was an examination of General Charles Howard, brother of O.O. Howard, who served as primary deputy commissioner of the bureau. Wide ranging in the topics explored, though he was not directly involved in the Barry Farm endeavor, Charles Howard provided some insight. A point raised repeatedly by the Democrats during the trial focused on the legitimacy of bureau activity - Barry Farm being one of those initiatives looked at skeptically. When Charles Howard was questioned about the need for a program like Barry Farm, he echoed Pomeroy stating that "there were poor Freedmen, occupying very miserable huts in the city; some of them had lived in barracks, from which they were turned out." ${ }^{20}$ Initially they tried to avoid undertaking such an extensive project, "we at first tried to reclaim some of [the barracks], cleanse them, and make them more fit habitations for human beings; but we no sooner found that that was utterly impossible." 21 A workable solution would require direct investment.

In response to the challenge, Pomeroy urged Howard to fund a solution that took into account that "they could not [afford houses] themselves because they had not anything to pay for them." 22 The senator, hearing of a recently widowed women seeking to unload a farm at the city's edge, suggested the Freedmen's Bureau purchase the land and develop it as housing for the freed people. His vision for the project entailed purchasing the farm, subdividing it into plots of approximately one acre each, then providing improvements to the land and supplies needed to build a home; essentially allowing the occupant to rent-to-own their self-constructed domicile at a rate between

\footnotetext{
${ }^{20}$ Ibid., 327.

${ }^{21}$ Ibid., 328.

${ }^{22}$ Ibid.
} 
\$10 and \$15 per month. Monthly rent, at that fee, made these healthy and safe houses significantly cheaper than what African Americans paid at the time for substandard lodging in the capital. ${ }^{23}$ The only challenge that remained was how to convince the widow to sell the farm when she was rumored to be no friend of the freed people.

This brought John R. Elvan into the mix, who provided the committee an insider's look into the process of creating Barry Farm when he testified. Elvan, a general hardware dealer by trade, occasionally fulfilled contracts for bureau constructed buildings, was asked to sit as one of the three trustees of the undertaking. While the Freedmen's Bureau could purchase property, and utilize it for revenue generating purposes, this could not happen without the seller's consent. Elvan, asked to join the board of trustees even though he came with limited direct experience, provided a person not recognized as an associate of Howard's, or any activist group, to facilitate the purchase of the land. Elvan reported to the committee that if the owner knew what purpose they intended for her farm, it would never have been sold. The merchant then, to avoid that obstacle, purchased the land as a private citizen. Approximately fifteen minutes after the deed was transferred to him, Elvan turned the property over to the trustees. ${ }^{24}$ To create separation between the bureau and Barry Farm, Howard set it up as a separate non-profit corporation, with himself, Pomeroy, and Elvan as the only trustees.

Indicative of the odd financial management practices of the bureau, there was never a need for the Barry Farm corporation to repay Elvan for the land. Though he purchased it for $\$ 52,000$ as an independent individual, he received the funds for it
${ }^{23}$ Ibid., 482.
${ }^{24}$ Ibid., 184-185. 
through a check from the Freedmen's Bureau, made out to him as a trustee, not to the organization, on a check drawn for the United States Treasury. The check was, however, drawn prior to their being an official Board of Trustees as it was also prior to the organization being chartered. Following the transfer of the deed, the organization received a charter, and Elvan assumed the position of board secretary. But Elvan was no longer needed. The official records of the organization were transferred to John A. Cole, a clerk in Howard's office, and Elvan's knowledge of the operations, policies, or procedures of Barry Farm largely ends there. ${ }^{25}$

As for the funds received for the purchase of the land, the topographical improvements, and the materials needed for the houses, all came from the bureau's Refugee and Freedmen's Fund. That did not, however, guarantee financial success. To increase the odds, Charles Howard explained to the committee, they "endeavored to select from among [freed people seeking housing] intelligent and enterprising men who would be likely to improve the lots and make their payments properly."26 Their management of the project proved effective, by the hearing Barry Farm was clearly a success. Three hundred lots sold and in good standing, fifty-nine waiting for buyers, and very few foreclosed for lack of payment. ${ }^{27}$

Barry Farm was just one small project in the bureau's extensive portfolio. By 1870 the operations of the Freedmen's Bureau were massive, and as agents in the field and staff, made decisions to address immediate needs, the ability to accurately trace back their actions to the accounting procedures became nearly impossible. General George

\footnotetext{
${ }^{25}$ Ibid.

${ }^{26}$ Ibid., 327.

${ }^{27}$ Ibid., 329.
} 
Balloch, the disbursing officer of the bureau attempted to make their financial transactions clear during the trial of Howard. Frustration ensued, with Congressman Anthony Rogers asking, "how many different kinds of funds have you, anyhow?"28 Balloch's answer did little to simplify the matter. "As disbursing officer of the Freedmen's Bureau, I hold the Congressional appropriation fund, that is one. I hold the Refugees and Freedmen's fund, that is two," Balloch continued, "I hold what is called the school fund, received from the sale of confederate property under act of Congress; that is three." ${ }^{29}$ The fourth fund he revealed as the 'Retained Bounty Fund,' while the fifth was the 'General Bounty Fund. ${ }^{30}$ Each fund carried different regulations for their use and management. In the Barry Farm example, funds from the Refugees and Freedmen's Fund (for the general welfare of the freed people) was given to the Barry Farm trustees, specifically for housing. Revenue from Barry Farm was transferred back to the Bureau, but instead of to the operational budget, which is where the initial investment originated, to what Balloch called the schools fund (officially the 'Education Fund') which was then used for the support of three particular African American schools. ${ }^{31}$ Consistently, funds left the bureau according to the purpose of the expenditure, but returned based on where the funds were allocated next.

On one hand, the Barry Farm endeavor was a success. Demand for the houses was high, encouraging him to found not one, but two schools, as well as a church and a fraternal society, all for the residents of Barry Farm. At one point, over the winter of
28 Ibid., 294.
${ }^{29}$ Ibid.
${ }^{30}$ Ibid.
31 Ibid., 482. 
1869 , it looked as if some of the homes would have to be foreclosed, but by being flexible, the arrears were caught up. By the time he testified before Congress, the senator reported, "a great majority of them have completed payments, and have got titles, and have got homes." 32 This early application of a charitable investment in a market good or as non-profit management scholars would call it, social entrepreneurship demonstrates the tremendous impact created from governmental involvement. Especially when the organization more closely resembled a nonprofit corporation than a branch of the War Department.

On the other hand, it demonstrates the pitfalls facing an organization with little oversight and operating without clear controls. There was no formal process for determining the appropriateness of the Barry Farm project. No application was reviewed and vetted. The only control over the funds and management of the effort was the presence of Howard and a sitting Senator on the board, something that would be considered a significant conflict of interest today. Against all odds, the project was a winner, and ended up being cost neutral for the Bureau - but not cost neutral for the Refugee's and Freedmen's Fund. That fund financed the project, as it directly spoke to the mission of the account, but cash returned to the bureau entered through a different revenue stream. In essence, the welfare of the freed people was bilked $\$ 52,000$ for the benefit of African American schools. Both are admirable causes, so this can be seen as real-world decision in an environment that offers no great choices. Barry Farm, however, is just the most benign example of the casual manner in which Howard managed the finances and mission of the Freedmen's Bureau.

32 Ibid., 482. 
The issue of vetting projects appeared when Congress probed the three schools that were selected to receive support from the Barry Farm payments. Congress never could ascertain why or how the three schools that received these funds were selected. Nor does the answer lie in the records of the Freedmen's Bureau held by the National Archives. Regardless, all three schools presented serious questions about how Howard was investing the bureau's funds.

The Richmond Normal School, of Richmond, Virginia, was the least controversial. A member of the Board of Trustees, Ralza M. Manley, was called before the committee, and his testimony made it clear that the selection process was hardly transparent. Manley reported that the school was chartered a few months prior to receiving financial support from the bureau, and was completely independent. Prior to funds being made available from the Barry Farm project, the Richmond Normal School received four grants from the Bureau for construction and operational expenses. ${ }^{33}$ When asked how the school was chose for support by Barry Farm, Manley replied "I made no application for assistance...I had often, in conversation and correspondence expressed a wish to have more means with which to erect a better and more suitable building." 34 Manley communicated this directly to Howard, in his role as the Superintendent of Freedmen's Schools for Virginia.

More controversial was the support lent to the St. Augustine Normal School of Raleigh, North Carolina. The principal of the school, Reverend J. Brinton Smith, the

\footnotetext{
33 Ibid., 241-244.
}

${ }^{34}$ Ibid., 244. 
secretary of the Board of Missions of the Protestant Church for Freedman, one of many organizations involved in spreading the gospel through public service among the freed people. In that position, he reported to the committee he saw firsthand the need for a normal school in North Carolina, and succeeded in raising some money for that cause. "I then came on to Washington to see General Howard, and to express to him my views, and consult with him in reference to such a school. He told me he was very glad to hear that we proposed to establish such a school," and that if they determined to place their school in North Carolina, "where the ground was not then occupied, he would give $\$ 5,000$ toward it." 35 Smith reported to Congress that he then went in search of a location, settled on Raleigh, and updated Howard on his progress. At that time Howard discussed the Barry Farm revenue with him, mentioning that it was earmarked for a normal school any normal school serving African Americans - in Washington, DC, Virginia, and North Carolina. This is the first indication that strategic planning of any sort went into the decision of how to utilize the Barry Farm funds. Howard told Smith that "you will have your share of that fund, whatever it may be." 36 By the time of Smith's testimony before Congress, St. Augustine received approximately $\$ 16,000$ in direct support from the Freedmen's Bureau (from the Education Fund), in addition to support from Barry Farm. ${ }^{37}$ But the seeds of controversy were sown by the way in which the school was organized. Smith's organization, the Protestant Church for Freedmen, was a missionary arm of the Episcopal Church. When they decided to organize the school, Smith was directed to meet with the Bishop of North Carolina as "in the Episcopal church there are

\footnotetext{
${ }^{35}$ Ibid. 255.

36 Ibid.

${ }^{37}$ Ibid., 256.
} 
certain laws which require that institutions in the diocese of a bishop shall be under his control, and that no person outside can work such institutions." ${ }^{38}$ The Bishop provided the names of the men who would serve as the trustees and he proceeded with organizing the school. To receive the promised funds, Smith made a report to Howard who objected to an aspect of the proposed bylaws. Under the direction of the Bishop the first draft of the bylaws stated that the Bishop would have the right to appoint new members to the Board of Trustees. But Howard, reflecting the emerging corporatist culture, demanded that, like the boards of other organizations, the trustees retain the right to elect replacements and new members. Smith acceded, and with this modification of process, proceeded with the members named by the Bishop..$^{39}$ But when the committee called before it Robert Avery, the Freedmen's Bureau Inspector for the State of North Carolina, the problems of such an arrangement became clear. Avery reported that in his official duties he became aware of support for the school coming from the bureau, and lodged a formal objection. First, that "some of the trustees appointed to manage this fund were known to me to be the worst rebels in Raleigh," and since not friends of freedmen, "I protested against placing money for that purpose in their hands, feeling assured that it would never be appropriated to the purpose designed." 40 Second, that from Avery's vantage point Smith seemed to be balancing so many different paid positions (reverend, secretary of the Protestant Church of the Freedmen, principal of the school) there was no way he could effectively run a school: "he took no personal interest in the cause, and

\footnotetext{
38 Ibid., 255.

${ }^{39}$ Ibid., 255-256.

40 Ibid., 434.
} 
would merely use his influence to help himself." ${ }^{41}$ With this example capacity building came into conflict with the hierarchal nature of the bureau, built by a formal chain of command.

Avery, still a soldier in the United States Army dared not step outside of army regulations to make his concerns heard. Therefore, he reported this matter to his direct supervisor, General Nelson A. Miles, Assistant Commissioner for the State of North Carolina. It is unknown as to whether this concern made its way to the Commissioner for the state, or even if Howard was aware of the problems. ${ }^{42}$ The Freedmen's Bureau, though functioning more like a foundation in its funding of schools, was hampered in internal communication by the fact that it was an arm of the War Department, with army officers occupying every important position. If a problem arose locally that was beyond the vision of Howard, the feedback loop of oversight was broken by the nature of the Bureau's military-like organization. Unlike the schools directly created by the bureauwhose management was often contracted out to other organizations, like the American Missionary Association - St. Augustine Normal School, like the two other schools support by Barry Farm funds, were beyond the control of the bureau. Unless a problem with a funded organization made its way into the school's self-produced annual report, the bureau lacked a method of communicating control issues to the only person making funding decisions.

41 Ibid.
42 Ibid. 
That lack of oversight structure, due to the nature of the Bureau's hierarchy not matching its wide range of activities, opened up the possibility of abuse. The Richmond Normal School seemed to receive funding only because a member of its board directly communicated with Howard. Funds for the St. Augustine Normal School were turned over to an unvetted board and executive, it is possible neither of whom were all that concerned with the mission of the school. But nothing was as concerning for members of Congress than the ways in which Howard himself manipulated the lack of oversight for his personal needs. This is not to say that Howard became fabulously wealthy from the purse of the bureau. In fact, testimony showed him struggling to maintain his personal finances, often overextending himself to aid the causes for which he was passionately committed.

The St. Augustine Normal School provides one of the clearest cases of manipulation in the charges against Howard. One of the grants given to the school from the Education Fund was set at $\$ 5,000$ by Howard; but it came after the school completed a major building project slating this grant to become part of their endowment. Understanding that this presented an opportunity for the school to invest, rather than immediately expend the funds, Howard offered a proposal. First, he mentioned that he was building himself a house in Washington DC and needed additional cash to complete the project; if the school would loan him $\$ 4,500$ of the $\$ 5,000$ dollars, he would provide security for the investment as well as pay an annual interest rate. Then, on second thought, he made a different offer. Instead of loaning him the funds, he would instead sell the school a plot of land within the city's limits that was expected to increase in value. After some investigation the school, through Smith, agreed to the purchase. This 
arrangement alone would be questionable at best - but when Congress interviewed Howard's primary aide they discovered that he probably did not even own the land he sold to the school. Instead, the land in question appears to have been purchased by the Barry Farm corporation, from revenue not directed back to the Bureau, in the hope of creating a second settlement for the freed people in Washington, DC. Howard, acting as the treasurer of the Barry Farm organization instead decided that a second project was too risky, and sought to liquidate the land. The accounting becomes fuzzy, but it appears that Barry Farm turned the land over to the St. Augustine Normal School, with Howard personally retaining the cash from the sale, at least in the short-term. ${ }^{43}$ The school's share of the Barry Farm disbursement ended up being a little more than $\$ 8,000$, which they turned over to Howard. One year later they valued the property at more than $\$ 13,000$. The school was happy with the transaction to say the least. ${ }^{44}$ For skeptical Congressmen this represented the type of questionable and hard trace financial transactions at the center of their investigation.

Odd financial arrangements with schools became a theme of Congress' findings. The proposition the general made to Fisk University is a bit simpler as it more clearly benefited Howard personally. John Ogden, who described himself to the committee as the principal of Fisk University, reported that he asked the Bureau for financial assistance in the amount of $\$ 2,500$. The request was granted and a check was presented to Ogden for $\$ 1,000$, along with a handful of checks of differing amounts that came to $\$ 1,500$ signed over to the university. But Howard offered another option. Rather than taking the odds

\footnotetext{
${ }^{43}$ Ibid., 253.

${ }^{44}$ Ibid., 259.
} 
and ends checks for $\$ 1,500$, Ogden could instead choose to accept $\$ 1,500$ worth of bonds issued by the Young Men's Christian Association of Washington, DC. Howard, the treasurer of the YMCA, assured Ogden that the organization could satisfy the bonds when they sought to turn them in, as well as the six percent interest being offered on the bonds yearly. Since Fisk University was not financially pressed at the moment, Ogden decided to accept the bonds. ${ }^{45}$ Testimony toward the end of the hearings revealed that Howard, as an individual, at some point owned more than $\$ 11,000$ worth of YMCA bonds. ${ }^{46}$ The rest became, once again, hard to trace.

When General Balloch, the disbursing officer for the Bureau appeared before the committee (over several days) one of the issues he touched on was the 'Retained Bounty Fund.' He explained to the Representatives present that when African American soldiers were first accepted into military service, the volunteers received a bounty from the state for whom they helped meet the recruitment quota. The initial commanding officer of these soldiers, General Benjamin F. Butler, declared that they were not capable of managing such a significant influx of cash while experiencing camp life, and Butler "ordered one-third of it should be retained and placed in the hands of the superintendents of negros affairs," but once the bureau was organized, "it was found that several of the superintendents of negro affairs had quite an amount of this money...still in their hands." ${ }^{47}$ By order of the Secretary of War, these funds were "turned over to the Freedmen's Bureau...they have been constantly endeavoring to find the men to whom it

\footnotetext{
45 Ibid., 261-262.

${ }^{46}$ Ibid., 399.

${ }^{47}$ Ibid., 294.
} 
belonged, or their families, and paying it over to them." ${ }^{48}$ Until then, it was up to Howard to determine how to manage the funds, which included investing the funds. Unlike the cash allocated by Congress to the bureau, which could only be held in United States government bonds, the 'Retained Bounty Fund' was much more flexible. When Howard found himself short on cash and long on YMCA bonds, he simply sold them to the fund. ${ }^{49}$

This was not the only time Howard made questionable decisions regarding his involvement in investment vehicles. Ralza M. Manley, from the Board of Trustees of the Richmond Normal School, relayed to the committee an ethically questionable scene. In September of 1868 he was informed that the school was slated to receive a dividend of the Barry Farm project, approximately $\$ 10,000$. When he arrived at the headquarters of the Freedmen's Bureau he visited with Howard for some time, in which he revealed that the school completed a capital campaign, and instead of using the Barry Farm funds to complete their building, would instead be investing them. Howard presented Manley with a solution. Instead of taking the funds in cash, Howard offered the school an investment opportunity that he personally backed: bonds of the First Congregational Church, located in Washington, DC. After making inquiries about town as to the financial stability of the church, as well as the building project the bonds funded, Manley decided to take Howard up on his offer. ${ }^{50}$ The minority faction of the committee attempted to determine whether the value of the bonds held to their purchase price, or grew in value as promised by Howard, but were stymied by their Republican peers. Congressman George Hoar,
${ }^{48}$ Ibid.
${ }^{49}$ Ibid., 38.
${ }^{50}$ Ibid., 241-242. 
speaking for the majority, claimed that "General Howard's connection with the transaction terminated when the bonds were paid over," in others words, buyer beware. ${ }^{51}$

But this was not a cut and dry transaction, nor Howard simply offering a reputable investment tool to a funded organization. Howard, a long-standing member of the First Congregational Church, was instrumental in the church undertaking issuing bonds in the first place. It was reported to the committee by a fellow member of the church that Howard told the trustees of the church that he "thought he could raise the money for us, if we should issue bonds of the church."52 The measures Howard took to liquidate the bonds should have been as concerning to the majority as they were to the Democrats on the committee. He convinced an organization receiving funds from the Freedmen's Bureau to invest them in his personal concern. It was revealed that he invested funds from the Retained Bounty Fund in these bonds as well. ${ }^{53} \mathrm{He}$ also used his unique pull with a university to liquidate the remainder of the church's bonds. But that transaction, one of many issues brought forward about that educational institution, was merely the tip of the iceberg. In Howard University, the many concerns about Howard coalesced into one problematic whole.

The creation of Howard University is one of the more bizarre tails in the history of nonprofit corporations because of the immediate and overwhelming financial support it received from the United States government. Or at least from the Freedmen's Bureau acting on behalf of the federal government.

\footnotetext{
${ }^{51}$ Ibid., 245.

52 Ibid., 149.

53 Ibid., 241-242.
} 
In 1866 a number of influential members of the First Congregational Church - the same church that issued building bonds that kept finding their way into Bureau business determined that Washington, DC should have a university for the education of African Americans. To provide some gravitas to the effort, this group invited their fellow congregant, Howard, into the planning. Hiram Barber, one of the founders of the university, told the committee that Howard was invited to join the effort after initial planning meetings were held, and after the decision was made to name the school after the general. But, he also reported that the inspiration to seek funding from the Bureau came from Howard, and was not part of the university's original plans. ${ }^{54}$

Support for educational organizations was not unusual for the Bureau. It has made arrangements with the American Missionary Association (AMA) to operate some of the schools they financially supported. The AMA would purchase a plot of land in an underserved area, then the bureau either erected a building or provided funds for construction. When the school opened the AMA recruited white school teachers from the north to staff the building. To offset teacher salaries and other administrative costs, the bureau provided a per pupil fee, usually referred to as 'rent' on the books of the organization. By 1870 the bureau transferred approximately $\$ 270,000$ to the AMA in support of their education program. ${ }^{55}$

Like the AMA approach to education, the Howard University plan began with a small building on a three-acre plot of land. According to R.H. Stevens, an original member of the Howard board, the initial plan for the university was to purchase a simple

\footnotetext{
${ }^{54}$ Ibid., 122-123.

55 Ibid., 375.
} 
building within the city limits. But when Howard joined the board, bringing promises of federal funding, and at the encouragement of Charles Howard, who was also asked to consult, the project expanded. They determined to buy a farm of significant size, the Smith farm, and bring to life a campus. The bureau, under the sole direction of Howard, provided more than $\$ 25,000$ for the initial payment for the land. ${ }^{56}$ In total, the Smith farm carried a price tag of $\$ 147,000$, all of which was granted to the university by the bureau. ${ }^{57}$ Some on the board questioned the legality and ethics of the bureau's investment. Barber mentioned that when Howard suggested he provide funds via the bureau, the rest of the board balked at the proposal. Howard assuaged their concerns by promising to “consult with the Secretary of War or the legal advisor of the Freedmen's Bureau" eventually reporting back to the board that "he had had consultations with some parties (I do not know who now), and that he had no doubt at all of the propriety of furnishing aid to the enterprise." 58 The minutes of the board noted that they agreed to move forward with construction of a main building and a dormitory, and to request the funds for these buildings from the Bureau. "Happily the law gave [General Howard] full authority to extend the sought-for aid, and he, himself, as the agent of the government, assumed the whole responsibility of accomplishing the work." ${ }^{59}$ Furthermore, "with the contractor who is employed in the erection of these buildings, the board of trustees has nothing whatever to do," yet, when the buildings were completed, "they will become the property

${ }^{56}$ Ibid., 146-147.

57 Ibid., 268.

${ }^{58}$ Ibid., 133.

59 Ibid., 137. 
of the university upon such conditions as a generous and fostering government may impose." ${ }^{\prime 0}$ These were non-existent.

Other questionable decisions would follow. The church bond liquidation effort that Howard placed so much personal stock in floundered. To sell what remained, and buoy faith in their value, Howard determined that Howard University would invest excess funds in the bonds. Without cash laying around, Howard directed Balloch to transfer $\$ 18,000$ from the bureau's Education Fund, which was then used to purchase $\$ 18,000$ worth of church bonds. ${ }^{61}$ The bonds became the beginning of a university endowment. One of the most significant indications of the problematic relationship between the bureau and Howard University is the method by which the university received funds from the agency. On Howard's orders, without any real external approval, Balloch, the disbursing officer, would write a check to himself, as the treasurer of the school. Approximately $\$ 180,000$ changed hands between the Bureau and the university in this method, all of it from one man writing a check on the United States Treasury to himself. ${ }^{62}$ While no one accused Balloch or Howard of manipulating that system for personal gain, the university's practices were another matter.

While faculty and administrators associated with the Freedmen's Bureau provided service for their compensation it certainly seemed as if Howard University became a federally funded piggy bank for the officers of the Bureau. General Eliphalet Whittlesey, the Adjutant General of the Freedmen's Bureau, also served as a professor at the university. In that capacity he petitioned the board for a right to one of the few houses
${ }^{60}$ Ibid.
${ }^{61}$ Ibid., 84.
62 Ibid., 272. 
constructed for faculty. This was in addition to his adjunct salary of $\$ 1,000$ per year. Howard, as 'Principal' of Howard University, received a salary of $\$ 5,000$ per year, in addition to his salary as Commissioner of the Freedmen's Bureau. Balloch, also received two salaries; his army pay through the bureau and $\$ 3,000$ per year as treasurer and general agent of the university. ${ }^{63}$

Still, these questionable hiring and compensation practices did not mean that Howard operated without impunity. The Board of Trustees determined to provide Howard, as the president of the university, with land on which to construct a home. Pointing to the ethical quagmire accompanying such a gift, the general declined the offer.$^{64}$ Due to the inability of Howard, as Bureau Commissioner, to ever completely separate himself from Howard, the university president, even if only in appearance, pitfalls persisted.

The D.L. Eaton Co. provided a curious adventure in this tale. Eaton's day job was actuary of the Freedmen's Savings and Trust Company, and where the Bureau travelled the bank tended to follow. Entwined with each other's operations, the bank often acted as the official agent of the 'Retained Bounty Fund,' verifying the identity of those claiming a bounty, and dispersing the cash. Freed people receiving support from the bureau, though not required, appear to have been encouraged to make use of the bank's services since it was a guaranteed fair actor in locales that tended to abuse African Americans. Furthermore, while the Freedmen's Bureau was prohibited by law from securing funds in non-United State Treasury depositories, entities adjacent to the bureau tended to select it

${ }^{63}$ Ibid., 258
64 Ibid., 129. 
as their bank - including Howard University. Eaton, an employee of the bank and not directly associated with the bureau or Howard, was certainly acquainted with both. When he determined to open a Washington, DC branch of the American Building Block Company, it was to the leadership of the bureau he went looking for investors.

Howard recognized the promise of a method of production that created bricks larger than the common building brick, in less time, at less cost, thought to be as every bit as strong as traditional bricks. He became an early investor. So was Henry Searle, the architect who regularly undertook projects for the bureau, including the buildings on the Howard University campus. As were Charles Howard, and J.W. Alvord, the General Superintendent for Education at the bureau. Though Howard eventually sold his stock in the company, it was the Commissioner who acquired a personal loan to purchase $\$ 10,000$ worth of equipment needed to begin production. ${ }^{65}$ In hindsight, it seems plausible that Howard, seeing the promise of discounted building materials, coupled with the fact that he independently made decisions regarding a number of building contracts, believed there was personal gain to be made while saving the government money. But like his other attempts at righting his financial misfortunes, this scheme encountered a challenge.

Though the decision to use this new building block material was made by the Howard University Board of Trustees, it appears to have been strongly influenced by Searle, the architect on the project. He encountered the material in other cities, Philadelphia in particular, and "spoke favorably of it to everyone...I did feel favorably towards the material and do now." 66 Shading how his response may have been interpreted

${ }^{65}$ Ibid., 378-381.

${ }^{66}$ Ibid., 115. 
by the committee, however, is the fact that Searle was an investor in the company. ${ }^{67}$ And with Howard retaining his interest in the company, at least initially, some of the board members asked to endorse this new building material voiced concerns.

Charles B. Boynton, a member of the First Congregational Church who was also part of the initial planning of the university, reported that when the block company entered the plans for the buildings, Howard made an unusual request. Still serving as Commissioner of the bureau, while also acting as president of the university, Howard requested that the board put aside a plot of land for the production of the building materials. All while he retained an ownership share of the company. This request pushed the ethical bounds too far. Boynton stated that after some discussion, the Board of Trustees determined that doing so might be against army regulations and that "it might involve General Howard, and perhaps the rest of us, in difficulty.... and I advised him to withdraw" from ownership of the company. ${ }^{68}$ Following that meeting Howard sold his share at face value to the other owners - all officers, or associates of, the bureau - and the university proceeded to donate one acre of land to the company for staging the production process. ${ }^{69}$ In retrospect, the donation was a heavy price to pay for access to a cheaper building material. In the most significant building project undertaken on the campus, the blocks used for the walls of the hospital building failed, caving in one end of the building. Rather than being a cheap alternative to traditional bricks, or the profitable investment assumed it would be for the Bureau's leadership, it was a disaster. At no time in the hearing was evidence presented that the failure of the hospital wall was intentional or the

${ }^{67}$ Ibid., 111.

${ }^{68}$ Ibid., 154.

${ }^{69}$ Ibid. 
result of malfeasance. John W. Rumsey, the general contractor for the buildings constructed at Howard University, reported that "if the materials had been good, there was no way in which the building could have been constructed so beautifully and so cheaply," and that traditional building methods would have increased the cost by approximately $\$ 25,000{ }^{70}$ But A.B. Mullett, the Supervising Architect of the Treasury Department, one of many experts called before the committee to weigh in on the building block material, discovered the defect. He reported that after testing samples of the blocks there were "very few" that "you could not crush into sand by the slightest pressure of your foot." ${ }^{\prime 11}$ After evaluating the blocks, he determined that the material produced by the company was simply not allowed to cure properly, and that if done correctly, would not have resulted in the hospital wall collapsing. ${ }^{72}$ The material was, in theory, strong enough, but the production process was haphazard.

The ineptitude of the company was on full display when Eaton came before Congress. He struggled to explain the firm's accounting documents. The company may have carried his name, but his interests, he explained, rested with the bank. Mr. Bliss, whom he identified as the manager of the company, initially kept the books but they fell behind and then Bliss passed away. Making sense of what remained appears not to have been a priority for Eaton, or the rest of the ownership group. They did not need accurate accounting to know that after the Howard University mishap they were not receiving orders, held little hope of attracting new customers, and the work completed on the contract for the hospital could only, at best, get them to the break-even point. When asked

\footnotetext{
70 Ibid., 108.

${ }^{71}$ Ibid, 118.

${ }^{72}$ Ibid.
} 
the status of the company, Eaton responded, "we made no further progress in the manufacture of material. Perhaps some trifling manufacture of stone was made, but the business of the company ceased, virtually, at the time of the accident." ${ }^{73}$ Regardless of who owned what - the minority faction of the committee was certain Howard secretly retained ownership - it was clearly bankrupt following the wall crumbling.

Though a setback for the owners of the company, and problematic for Howard, this did not end the Bureau's significant financial support for the school. Beyond the payments for the land, the bureau made a significant investment in the infrastructure and buildings of the campus. For example, the dormitory cost $\$ 63,357.07$, surveying, $\$ 826.37$, building streets, $\$ 2,010.03$, fences, $\$ 1,295.35$, and grading the land prior to construction commencing came in at $\$ 4,523.53 .{ }^{74}$ Between those improvements, and the other buildings (including a main campus building and a hospital), the bureau spent more than $\$ 150,000$ on campus improvements. ${ }^{75}$ All before the first lecture was given. When students arrived on campus the bureau's involvement only deepened, and in many ways, complicated.

When Joseph M. Brown, the Quartermaster of the Freedmen's Bureau appeared before the committee, arrangements between the Bureau and the university became evident. In 1869, the boiler of the newly constructed Howard University main building stopped functioning. Since the Bureau kept its headquarters offices in an unused space in the main building, Howard decided to pay for all of the upkeep of the building. The university's preferred contractor for the work was Hiram Barber, who already received

\footnotetext{
73 Ibid. 390-395.

${ }^{74}$ Ibid., 281.

75 Ibid., 283.
} 
pay as something akin to a groundskeeper, in addition to sitting on the Board of Trustees. Barber, along with the laborers he employed, received pay directly from the bureau, in addition to their regular university pay for maintenance, also funded by the Freedmen's Bureau. The Bureau even supplied all of the fuel for the boiler. In addition, there was the $\$ 2,500$ per year the Bureau paid to Howard University in rent, for space in a building for which the federal government completely financed the construction. ${ }^{76}$ To be fair, Brown reported that the move to the Howard University building, while not saving money, also did not increase expenses it did provide the benefit of bringing offices that previously were strewn about the city into one central building. Not that the Bureau constructing buildings and then turning them over to educational organizations was unusual. This happened at Lincoln University in Pennsylvania, Oberlin College in Ohio, Wilberforce University in Ohio, and the Colfax School in Washington, DC, to name a few. ${ }^{77}$ In each of these cases the bureau undertook construction and management of the contractors, completed the building on land owned by the school (occasionally with the purchase of the land funded by the bureau) and then turned the deed for the building over to the school.

Making sense of these individual cases proved relatively easy with investigation from the committee members, while gaining a full picture of the Bureau's operations remained elusive. Much depended on point in time comparisons and reports, especially given that a total accounting of dollars dispersed was nearly impossible to provide. The chaos of the post-war landscape made clear accounting a challenge. After the committee

\footnotetext{
${ }^{76}$ Ibid., 213.

${ }^{77}$ Ibid., 220-222.
} 
asked for specific documentation, Balloch presented a rough breakdown of certain accounts. He produced his fund accounting from March 15, 1869 as an exemplar of the ebb and flow of cash through the agency's books. On that date, the Bureau held more than $\$ 1.7$ million dollars on hand, between all funds. Expenditures for school buildings, built from scratch or rentals of existing buildings, amounted to \$1 million - 630 schools in total owed their existence to the bureau. ${ }^{78}$ To any reasonable observer, given the scope of operation and the impact, many of the Bureau's missteps were excusable. This truly was a herculean task.

Howard University, however, remained a thorn in the side of the Bureau when brought into the light of day. The Chairmen of the committee, Congressman Samuel M. Arnell of Tennessee, asked perhaps the most insightful question of the whole inquiry as they discussed the university: "Why were the amounts [given to Howard University] so much larger than the amounts given to other institutions?"79 As the person who made all of the decisions regarding what organizations and projects received funding, Howard was the most qualified to answer. But the committee never directly questioned the general, and Balloch was instead pressed for an answer. "I suppose," he began, "it was because other institutions had been assisted by benevolent associations, but the Howard University never has been." 80 He continued, "those other institutions have been assisted by the bureau in part; while the Howard University has had to depend entirely upon the bureau." ${ }^{81}$ Interestingly, one of the sure signs that a nonprofit organization or a mission
${ }^{78}$ Ibid., 307.
79 Ibid., 291.
${ }^{80}$ Ibid. 291-292.
${ }^{81}$ Ibid. 
driven project is not a suitable investment is a lack of public support. Grant making foundations operating even just ten years later would not have dreamt of supporting a school without an existing program and outcomes to assess.

In the end, to the chagrin of the minority faction of the committee, Howard was acquitted of all charges. Which was somewhat hard to believe given the great number of issues: funds dispersed without strategic planning or vetting, double dealing between the Bureau and organizations employing its officers, Howard using his control of Bureau resources to arrange loans and other personal financial transactions, using the Bureau's position to funnel contracts to supporters and subordinates, and providing funding for organizations without an expectation of specific outcomes. Much of this was influenced by the politics of the day, with Republicans on the committee overlooking questionable practices in order to support the Reconstruction project, and Democrats finding fraud in even the most benign mistakes to weaken the political status of African Americans. After three months of investigation the final question was to determine how the United States Treasury regulated the transactions of the Bureau. Regardless of the mistakes made by Howard and the Bureau the real problem rested in the bureaucracy of the United States government.

When J.M. Broadhead, Second Comptroller of the Treasury, appeared before the committee it became evident that no real controls were in place. As Broadhead explained to the investigating legislators, he and his clerks, were responsible for reviewing the expenditures of the Bureau. Often his testimony consisted of Congressmen presenting 
hypothetical transactions and Broadhead giving some sense of how they were handled. "Supposing that General Ballock," asked one member of the committee, "wants to draw $\$ 25,000$ out of the treasury for Howard University, or any other institution purporting to be for the education of the freedmen?"82 Broadhead explained, "He does not state for what purpose he wants it. He draws out the money, and afterward furnishes vouchers to show how it was expended." 83 Eventually, a larger point is drawn out of Broadhead:

"Q. Supposing it is paid to the contractor for the building of Howard University, what papers do you see to show you it is paid according to the law? - A. The same papers that I see in connection with any of these disbursement.

Q. You do not seem to have quite caught my meaning yet. Suppose that General Balloch draws out of the United States Treasury $\$ 25,000$ and pays it to a single contractor, the contractor gives a receipt for the money; the receipt comes to you as a voucher; now, what papers do you see to prove that expenditure? - A. If the expenditure is one that is sanctioned by law-

Q. Right there is the point. What papers do you see to show that the expenditure is one that is sanctioned by law? - A. We see the receipt of the party who has done the work. The bill is made out in items, and presented with the account-an abstract of it.

${ }^{82}$ Ibid., 466.

${ }^{83}$ Ibid. 
Q. Any other papers do you see? - A. No other, except the approval of the Commissioner; that is required." 84

In essence, the only real check on Howard's power of the purse was a receipt and his signature. It is a small miracle that the Freedmen's Bureau did not become the home of rampant fraud along the lines that the Democrats of the committee continually suspected.

Howard obviously made mistakes as Commissioner of the Freedmen's Bureau. Most of them were the natural outcome of operating in an ever changing and difficult environment. Some were for personal gain. A few were to support the men and institutions who supported him. Almost all focused on building a better future for those who spent their past in slavery. Considering the limited restraints on his ability to dispense funds it is notable that so much of the Bureau's financial resources ended up allocated to building the capacity of the African American community instead of personal fortunes. Regardless, Howard's effectiveness and generally upright allocations, exposes the problem with this approach to building the nonprofit sector.

The federal government, from the Civil War until the coming of the Associational State, lacked the bureaucratic expertise to build the capacity of nonprofit corporations and the emerging nonprofit sector. Many of the Freedmen's Bureau's early investments paid dividends but this was due mostly to the raw power of cash. Howard's trial made it

${ }^{84}$ Ibid. 
obvious that the Bureau's pragmatic approach never transitioned to strategic thinking, the vetting of projects and institutions, and a demand for specific outcomes. While the capacity building possibilities of the federal government remained large, it would not be until decades later that this force would be brought to bear in any meaningful way. A different quasi-governmental organization, the United States Sanitary Commission, financially and operationally independent of the federal government, would point the way to the future of the nonprofit sector. 


\section{Chapter 4}

The Peabody Foundation

The Peabody Education Fund began as other $19^{\text {th }}$ century philanthropic endeavors tended to materialize - with a letter from the founder, to the hand-picked board members, summarizing the mission. A more illustrious group would be hard to find in the years immediately following the American Civil War. There was Hamilton Fish, Secretary of State; General Ulysses Grant, commander of the Union Army and future president of the United States; Admiral David Farragut, commander of the Union Navy; Robert Winthrop, former Speaker of the United States House of Representatives; William Aiken, the former Governor of South Carolina; William Rives, former Ambassador and Senator from Virginia; and Charles P. McIlvane, a prominent Bishop of the American Episcopal Church, to name but a few. ${ }^{1}$ Such prominence among the members of a high profile board was not unique. What sets the Peabody Fund apart from its contemporaries, however, is in the charge made to those board members by the founder at the outset.

Though an act of philanthropy, Peabody made clear to those he entrusted with his beneficence that his concern was largely one of the market economy and maintaining the wealth it produced. Reflecting on the post-war economic boom experienced in the United States, Peabody commented, "but to make her prosperity more than superficial," the nation's "moral and intellectual development should keep pace with her material

${ }^{1}$ Trustees of the Peabody Education Fund, First Meeting of the Peabody Education Fund (1867), 11. Reprinted in: Trustees of the Peabody Education Fund, Proceedings of the Trustees of the Peabody Education Fund From Their Original Organization (Boston: John Wilson and Son, 1875). 
growth."2 In the South, where "the urgent and pressing physical needs of an almost impoverished people must for some years preclude them from making," without assistance, "such advances in education, and such progress in the diffusion of knowledge, among all classes, as every lover of this country must desire.” For Peabody, action was needed to aid national prosperity. ${ }^{3}$

Peabody viewed education in the South as foundational to the growth of the market economy. For this purpose he provided the Trustees one million dollars (shortly thereafter augmented with another million dollars and various bonds). Those funds, held in trust, except "the income thereof used and applied at [the Trustees'] discretion for the promotion and encouragement of intellectual, moral, or industrial education among the young" of the Southern states. ${ }^{4}$ His purpose "being that the benefits intended shall be distributed among the entire population, without other distinctions than their needs and the opportunities of usefulness to them," ensured a charitable foundation concerned with the whole of the South. ${ }^{5}$ To this open ended arrangement Peabody stipulated a few requirements. For the first two years of its existence, the Trustees were authorized to dispose of up to forty percent of the principal to jumpstart the effort. If they felt it in the best interest of the Fund, they could seek a charter and the accompanying legal recognition. They applied for a charter in New York the following year. Peabody authorized the hiring of a General Agent to act as the representative of the Fund, and that

${ }^{2}$ George Peabody, Letter of George Peabody (1867), 2. Reprinted in: Trustees of the Peabody Education Fund, Proceedings of the Trustees of the Peabody Education Fund From Their Original Organization (Boston: John Wilson and Son, 1875).

${ }^{3}$ Ibid., 2-3.

${ }^{4}$ Ibid., 3.

${ }^{5}$ Ibid. 
person's salary and expenses could be carried by the principal. And lastly, in a rare demonstration of naivety for a captain of industry, Peabody authorized the Trustees, with a two-thirds vote, to end the Fund after thirty years. Peabody assumed that thirty years of grants and effort could resolve all challenges. Beyond that, he left "the details and organization of the Trust with you [the Trustees]...I give to you power to make all necessary by-laws and regulations."6 Like the letter of initiation provided by John Slater to the Salter Fund a decade later, Peabody's open ended charge to the Trustees was relatively vague and flexible. As a businessman, the founder of the Fund seemed to understand the need to evolve and change as the landscape shifted. Unlike Slater, when Peabody's Fund swung into action he was still very much alive.

At the first meeting of the Trustees, the members made two important decisions. Previously they dispatched a member South to gather information regarding the status of education. His primary observation, that the field of work was large and complex, led to the hiring of a General Agent. They determined to lure away from the presidency of Brown University, Barnas Sears, a well-regarded educator with a persuasive and likeable demeanor. Following that move, representatives of the Board met with Peabody, reporting that he "expressed his desire that at the outset as much as possible should be done for common school or rudimentary education."7 Acquiescing to his vision the Trustees determined that "measures might be adopted as would, for the present, give such an education to the greatest number of children." 8 The noncommittal tone of their

\footnotetext{
6 Ibid., 5-7.

${ }^{7}$ Trustees of the Peabody Education Fund, First Meeting of the Peabody Education Fund (1867), 15.

${ }^{8}$ Ibid.
} 
language was reflective of the independence the Board reserved in decision making, theoretically free from the influence of the founder. In a letter to the Board, meant to address a rumor circulating in the South that the Fund's largess would be reserved for particular locales, Peabody reasserted that “...it was not my design to bind the Trustees...I leave all the details of management to their own discretion." ${ }^{.9}$ Regardless, his word was gospel. Following his appointment, the new General Agent spent six weeks at a retreat in Sulphur Springs, Virginia with the now ailing Peabody. At these daily meetings Sears used the location - popular with the well-to-do and well-connected of the South to trade on Peabody's influential circle of friends, while at the same time gaining a fuller understanding of Peabody's intent. ${ }^{10}$ Sears, seeing the wisdom of Peabody's corporatist perspective, ran with it.

With Peabody's business-like approach in one hand and a small fortune in the other, Sears began to mold an organization geared to meeting its mission while encouraging corporate culture in pursuit of a stable market economy in the South. Funding was predicated on achieving measurable outcomes. Schools receiving grants had to ensure proper financial management. Not only did the Peabody Fund use its resources to encourage a corporate culture among those it chose to invest in - in a reversal of the model presented by the Freedmen's Bureau - it leveraged resources to inspire capacity building among government agencies. With the experience of the Peabody Foundation the nonprofit sector, fueled by enormous private wealth, demonstrated the power of

\section{${ }^{9}$ Ibid., 22.}

10 Trustees of the Peabody Education Fund, Eighth Meeting of the Trustees (1870), 183-184. Reprinted in: Trustees of the Peabody Education Fund, Proceedings of the Trustees of the Peabody Education Fund From Their Original Organization (Boston: John Wilson and Son, 1875). 
donors to shape organizations and government alike. All in service to a widening market economy.

In his first report to the Board as General Agent, Sears presented not just his year in review, but a plan of action for the disbursal of funds, informed by Peabody's suggestions. Systematization, a defining trait of corporate culture, became clearly necessary for the Fund to wisely invest its resources. Even prior to officially being hired, Sears found himself confronting an avalanche of letters "of the most diverse character, and proposing widely divergent plans of action...to be answered at my discretion."11 With no experts in education on the Board to help guide their funding policies, Sears went in search of those in the know, including trips throughout the South to observe the state of education for himself. After this cursory exploration he felt strongly that the combined wisdom of those he consulted pointed to "adopting a comprehensive plan for the general improvement of the schools, rather than a doling out charitable aid to all who are in want." 12 The obstacle he discovered, prior to making a single grant, was "that of yielding to the importunity of selfish individuals or corporations, who care less for the public good than for the advancement of their own interests, or who, in their zeal for their own cause, are blinded to the larger and juster claims of society in general."13 Like any

${ }^{11}$ Trustees of the Peabody Education Fund, Fourth Meeting of the Trustees (1868), 39. Reprinted in: Trustees of the Peabody Education Fund, Proceedings of the Trustees of the Peabody Education Fund From Their Original Organization (Boston: John Wilson and Son, 1875).

12 Ibid.

${ }^{13}$ Ibid. 
investment - for profit or the common good - the Trustees needed a plan predicated on research.

Even with a thoughtful process in place, danger lurked around every corner. As he travelled the South, discussing the benefits of publicly funded education, and offering financial support to schools, Sears discovered "in several instances...the deceptive nature of the representations made to me, just in time to save myself from a mortifying blunder." ${ }^{14}$ In some cases, even after making offers of support, he was forced to "withdraw assurance or encouragement given under circumstances which seemed to preclude the possibility of mistake, but which really concealed half of the facts from my view." ${ }^{15}$ Even if creating work for himself, and taking longer periods of deliberation, Sears found no regret to an "over-cautious course."16

The first step was to determine what sorts of schools the Fund should financially support. In some ways, it was easier for Sears to identify organizations that would not be receiving support from the Fund: charities, colleges, orphanages, private schools, and individuals. ${ }^{17}$ Instead, they would follow nine specific guidelines for funding. They echoed Peabody's initial guidance, prioritizing “promoting 'Primary or Common School Education,' we confine ourselves, as far as possible, to Public Schools." 18 To produce some efficiency in their donations only schools with a significant number of students would be supported. This was to avoid diffusing funds throughout the small villages of the South where only a handful of students would be found, but also to provide notable
14 Ibid., 40.
${ }^{15}$ Ibid.
16 Ibid.
${ }^{17}$ Ibid., 39.
${ }^{18}$ Ibid., 56. 
models of what could be achieved through public school education by funding schools in population centers. Once identified, they would fund a select school in a city, sometimes more than one, but even then keep the numbers limited so the impact of their support was evident. Donations would be made strategically, to encourage the adoption and reform of state-wide public school systems throughout the South. Part of that strategic effort included funding Normal Schools to improve the supply of qualified teachers in state's with emerging public school systems. So that African Americans also benefitted from the Fund's work, teachers from those communities were encouraged to attend Normal Schools, both segregated and integrated. Last, since a well-functioning, state-wide system of public education required capable administration, the organization encouraged the appointment of State Superintendents of Education, the organization of state teachers' associations, and professional journals for teachers. With guidelines in place all that was needed, if only to serve as a guardrail, was a formula for determining financial support. In the first year, Sears, with the approval of the executive committee of the Trustees, landed at a simple formula. For a larger public school - his example settled at 700 pupils - the Fund would provide a maximum of $\$ 1,000$, so long as the public expenditure toward that school system was at least four times that amount. Half as many students, with only three times their donation in tax revenue, received a grant of $\$ 500 .{ }^{19}$ Adjustments to this funding model occurred regularly, however, the Fund maintained its focus on number of students, level of public financial support, with a generous but reasonable cap to spread resources as widely as possible.

${ }^{19}$ Ibid., 46. 
Shortly after the announcement of the Fund, in 1868, the Virginia State Legislature, taking advantage of the Board holding its annual meeting in the state, invited the organization to speak to the assembly on the importance of education in the South. ${ }^{20}$ The Trustees dispatched Sears to make the address, providing the first public forum for the Fund to convey its philosophy to the nation, and in selecting Sears for that role, assured this statement of their mission conformed to his strategy for distributing funds.

Sears began by acknowledging that some held the Fund's true nature in suspicion and contempt. The Fund's efforts, he informed the gathered legislators, boiled down to "free schools for the whole people - neither more nor less." ${ }^{21}$ Regardless of the form the efforts of the Fund took, it would all be in pursuit of this grand aim. One aspect of the enterprise that was certain was the concentration of their aid; Sears promised that the Fund would "select some one part of the great system of education, and bring out some decisive result," in order to avoid the scattering of efforts, "like the dew, to vanish and leave no trace behind." 22 That meant ignoring the conditions and requests of colleges, and the private schools of the well-heeled, instead focusing on the most rudimentary of schools, and sometimes supporting the training of teachers for those schools. To Sears, investing in the poor seemed the most secure. From his perspective, there was "generally greater danger" that those who "have been brought up in the lap of luxury" would never exert the energy to achieve something. ${ }^{23}$ The poor, "born to hardship and toll" whose positions were not "secured by accident of fortune" would be "forced to the greatest

${ }^{20}$ Fourth Meeting of the Trustees (1868), 61.

${ }^{21}$ Ibid.

22 Ibid., 62.

23 Ibid., 64. 
activity and energy by the very necessity that is laid upon them." ${ }^{24}$ In fact, Sears went so far as to contend that if Virginia did not support public education - limiting the arena in which the poor could productively prove their metal - then the state would find its number of future "best men" significantly reduced. ${ }^{25}$

Most telling in his address, as alluded to in his thoughts on the drive of the poor, was the degree to which the market economy and success therein peppered his remarks. His assertion that the wealth of the state was not in its resources, but instead "...lies in the intelligence, industry, energy, and character of the people," seems like the kind of throwaway fluff expected in a speech of this nature. But he elaborated, making it clear that his primary concern was not the deep thinking of the humanities, or the experiments of the sciences, but business. "The mind that is stored with a knowledge of art or science, such as are within the reach of every man who has a good elementary education," he began, then linking the mission of the Fund to the market by continuing, "and has learned, by habits of study, to be accurate and thorough in all that it undertakes, will almost certainly acquire the practical skills in any calling." ${ }^{26}$ Since "intellectual activity and success in business usually go hand in hand...let the general mind be highly enlightened and well trained." 27 The result, Sears contended, was the molding of "many well qualified competitors in the different branches of business, and you will see the effect in improved agriculture and mining process...progress in the mechanic arts." ${ }^{28}$ Not to mention "the introduction of the various branches of manufactures" and "an increase
24 Ibid.
25 Ibid., 65.
26 Ibid., 67.
${ }^{27}$ Ibid.
${ }^{28}$ Ibid. 
of commerce." 29 Taking his rhetoric one step further, pushing education even deeper into the market economy, when Sears identified the purpose of education as "the business of education." ${ }^{30}$ Not only was the Peabody Fund viewed by its Trustees and General Agent as a corporation operating in a corporate environment, its mission - to increase access to education - also served as an extension of the market economy.

Even with a solid plan in hand, complications confronted them at every turn, and this was especially true of developments that went unaccounted for in Sears' initial formula. Nothing revealed that reality quite like the frequent donations of textbooks the Fund received. Even before the Fund's official commencement, the first letter from a textbook publisher arrived, cheering their mission and offering support. A.S Barnes \& Co. of New York City, mused "it is probable that the use of meritorious text-books will prove a most effective agency toward the thorough accomplishment of Mr. Peabody's benevolent design." 31 As such, they "selected from their list some of the most valuable, and ask the privilege of placing them in your hands," for distribution to schools receiving funds from the foundation. ${ }^{32}$ The Trustees, via the Chairman, Robert Winthrop, replied favorably to the offers, commenting that "I shall take the greatest pleasure in laying it before the Board at their earliest meeting," in which the donation was expected to be

29 Ibid.

${ }^{30}$ Ibid., 63.

${ }^{31}$ Trustees of the Peabody Education Fund, Third Meeting of the Trustees (1867), 34. Reprinted in: Trustees of the Peabody Education Fund, Proceedings of the Trustees of the Peabody Education Fund From Their Original Organization (Boston: John Wilson and Son, 1875).

${ }^{32}$ Ibid. 
accepted. ${ }^{33}$ Winthrop stated that the donation, when combined with the donations of other publishers, "will go far towards supplying the immediate demand for publications of this character, and will furnish an example which will not be forgotten as our work advances." 34 Though the Trustees avoided the consequences of this donation - not quite perceptive enough to see this as an attempt to become the official textbook provider of the South through the endorsement of the Peabody Fund - it quickly became a thorn in the side of their General Agent.

Sears tackled the topic in his first year, relaying to the Board the various requests they received from schools for textbooks, and then assessing the challenges. There were many. Since schools would only use a book if they received enough copies for everyone, distribution was not as simple as dropping them in the mail. ${ }^{35}$ Not to mention teachers complaining about frequent changes to the textbook impacting their curriculum. Or that in many places parents were required to purchase new textbooks once the school's supply was exhausted. Complicating matters further, as well as the General Agent could surmise, Northern textbooks could not be purchased in Southern bookstores. While not what was intended by the publishers, it appeared to Sears that the best path forward was to dumb them on a handful of schools quickly, and refuse future textbook donations. ${ }^{36}$ How these donations were ultimately disposed of us is not clear. What was evident was that Sears wanted out of the textbook supply business, and was successful in that effort. The issue

${ }^{33}$ Ibid., 36.

34 Ibid.

35 Trustees of the Peabody Education Fund, Fifth Meeting of the Trustees (1868), 113. Reprinted in: Trustees of the Peabody Education Fund, Proceedings of the Trustees of the Peabody Education Fund From Their Original Organization (Boston: John Wilson and Son, 1875).

${ }^{36}$ Ibid. 
of textbooks never comes up again. With laser like focus, the Peabody Fund was narrowing its mission to what was manageable and the most likely to pay dividends.

In July of 1868 Sears made his first full report to the Board; after spending several months traveling there was much to ponder. In general, he found that the communities he visited embraced public education, and where he encountered apprehension, it was usually related to a sense that government at the state level remained unstable. In the Southern states - the Fund's field of operations - the political resolution of the Civil War remained undetermined. His experience with communities tended to reflect the degree of Republican control in the state more than local conditions. ${ }^{37}$ Yet, he made significant headway. In only one of the cities he visited did he find his offer of help, if combined with public funding for education, declined. In that case Sears later learned that all of the men who sat on the town council were bachelors and unwilling to raise their taxes in support of others' children. ${ }^{38}$ Everywhere else he found significant interest.

In Raleigh, North Carolina, the African American school aged population of around 800 had more than 700 regularly attending schools funded by the Freedmen's Bureau. Of the city's 600 white children, only 275 attended schools, most privately funded. He offered the city $\$ 500$ if they would secure at least $\$ 1,500$ in public funding to ensure access to education for the white children of the community. ${ }^{39}$ One of the oddities of the South during these early years of Reconstruction, as Sears often found, was that the children of the freed people generally attended schools, operated by the Bureau or

\footnotetext{
37 July, 86.

${ }^{38}$ Ibid., 87.

${ }^{39}$ Ibid., 100.
} 
charitable organizations, while white children went without free options. In Charleston, South Carolina, where the African American population was roughly the same as Raleigh, a larger white population had even fewer students enrolled. Sears offered a onetime donation of $\$ 2,000$ if the community would provide the same ${ }^{40}$ Often the work of the Fund's General Agent benefitted both black and white children, such as his encounter in Pendleton, South Carolina. There he found a community completely without schools, and with elected officials completely unconcerned. This was one of the very few times in which the Fund acted without a contribution from the community - Sears arranged for a former professor of his, assisted by the man's spouse, to provide instruction to 100 white and 100 black - with the hope this would inspire public action. ${ }^{41}$

In some communities Sears was forced to work a bit harder to convince elected officials and the voting public of the wisdom of public education. In Jacksonville, Florida, he immediately ran into opposition, even though there were not schools in operation at all, and more than a few families were considering sending their children North to attend private schools. To that audience Sears' advocacy for public schools became a matter of simple arithmetic. As he explained to the community, if the cost of educating those students sent elsewhere was collected (he estimated the expense between $\$ 500$ to $\$ 800$ per year per student) from just those families, they could provide a wellfunded public school system for the entire community. Sears reported to the Peabody Board that after laying his projections before them, they sprung into action creating a plan for public schools. This new school system, at a cost of $\$ 4,000$ per annum, on Sears'
${ }^{40}$ Ibid., 101.
${ }^{41}$ Ibid., 101-102 
designation, received $\$ 1,000$ of support from the Fund. ${ }^{42}$ In St. Augustine, Sears ran into another set of peculiar local conditions. There a robust private Catholic school system existed, which gave the protestant community the impression that a public school system would be unpopular in this almost majority Catholic community. From the outset, with this assumption in mind, Sears was told public schools were unrealistic. He proceeded with a community meeting to discuss the benefits of public education, at which all were surprised to find that the Catholic male heads of household were dissatisfied with their education options, both in terms of expense and quality. Somewhat tongue-in-cheek, Sears reported to the Board that the Catholic men "...thought that by paying a school tax they would anticipate and ward off the objections of their wives, instigated and influenced by their priests" to enrolling their children in public school. ${ }^{43}$

Selma, Alabama, offered a scene reflective of both Jacksonville and St. Augustine. With no public schools to speak off, families paid exorbitant tuition for local private schools of questionable value. Those with the resources opted to send children North to quality schools, paying even higher prices. In a quick survey of families, Sears determined that the city collectively spent approximately $\$ 12,000$ per year on private education. At $\$ 75$ per year per student, Selma’s families expended much more than the $\$ 17$ per student it cost to educate a child in Boston's public schools. In this case, it became clear that their lack of access to affordable education produced obstacles to economic growth; the city's leaders reported trouble recruiting skilled workers to the city because living there meant tuition spent for their children. After reviewing potential plans

\footnotetext{
42 Ibid., 104-105.

${ }^{43}$ Ibid., 105.
} 
for their system, Sears offered a contribution from the Peabody Fund of $\$ 2,000$ for the following year if the city would commit to raising $\$ 4,000$. Before he departed, the committee tasked with raising the funds set their sights on $\$ 5,000 .{ }^{44}$

Sometimes Sears found cities already experimenting with public education, but encountering challenges nonetheless. In Memphis, Tennessee, the General Agent found a community that paid more than $\$ 60,000$ in state required, state collected, and state disbursed education taxes. In addition, the city imposed taxes amounting to an additional $\$ 60,000$, resulting in a public school system with an annual budget of $\$ 120,000$. The only problem in this arrangement was that the state legislature failed to disburse the state collected funds, leaving the public school system with a significant deficit. To alleviate, even just a little, this financial crunch, Sears arranged for the city to receive $\$ 2,000$ in support from the Fund. Though an important gesture, his presence proved even more significant. The school board pressed him to remain a few more days in order to address a community meeting on the importance of public education - a meeting taking place a few days prior to the city's voters deciding if they should levy another $\$ 30,000$ on behalf of education to make up for the state's inaction. ${ }^{45}$

Sears spent the rest of 1869 on the road, expanding the scope of the Fund's work to the periphery of the South - West Virginia, Arkansas, and West Tennessee - finding much of the same, but attacking local problems with creativity and an entrepreneurial spirit. In Fairmont, West Virginia, he found a public school in operation, serving a student population of 300 , with quality teachers, but terrible facilities. At the same time,

\footnotetext{
${ }^{44}$ Ibid., 107.

${ }^{45}$ Ibid., 111-12.
} 
nearby, he found a small teachers college erected a building, but failed to operate for financial reasons. His proposal, aimed at solving both problems, promised $\$ 1,000$ to the public school, and $\$ 500$ to the Normal School if they agreed to work in a symbiotic way: the teachers college would rent an unused wing of their building to the public school system, for which they would receive $\$ 1,000$ per year in rent (in reality paid by the Fund), and the students in the Normal School would provide student teachers for the public school. With both institutions' challenge resolved, they agreed to Sears' scheme, and he went on to the next community. ${ }^{46}$ At Pine Bluff, Arkansas, Sears' encountered a community, once again, paying for ineffective private schools, sending students North for education, and in aggregate spending much more on education than would be required to maintain a quality public school system. He offered them $\$ 800$ from the Fund if the city committed to raising $\$ 3,000$ to provide free education for all children. ${ }^{47}$ In Chattanooga, Tennessee, Sears found a functioning public school system, serving more than 1,100, at a yearly cost of $\$ 9,000$. To encourage their continued commitment to this relatively young system, Sears' offered $\$ 2,000$ in Fund support. ${ }^{48}$

In reflecting on their first full year of engaging with communities all over the South, Sears could not help but be hopeful, “...our method of distributing the Fund has called forth strong expressions of approval from nearly every Southern man who has spoken on the subject." ${ }^{49}$ Of particular strength in their plan was "that feature of it which

46 Trustees of the Peabody Education Fund, Sixth Meeting of the Trustees (1869), 120-121. Reprinted in: Trustees of the Peabody Education Fund, Proceedings of the Trustees of the Peabody Education Fund From Their Original Organization (Boston: John Wilson and Son, 1875).

${ }^{47}$ Ibid., 127.

${ }^{48}$ Ibid., 131-132.

${ }^{49}$ Ibid., 138. 
requires the energetic co-operation on the part of the recipient..."50 Furthermore, he assured the Board, "it has been said and repeated again and again, that the effect of our work in arousing the activity of the people, will be far more valuable than the temporary relief that is afforded to the needy." ${ }^{51}$ The system designed by Sears, in consultation with Peabody, was paying dividends. Communities were establishing public school systems, with the Fund's significant, but limited, financial support; more importantly, those communities were establishing public school systems that would eventually stand, permanently, on their own two feet.

As Reconstruction receded with the coming of the 1870 s - especially in places where Republican governments saw electoral loses early - the challenge before the Fund shifted from local proclivities and uncertain state legislation to outright hostility or incompetence within state governments. Legislation regarding education, Sears informed the Board in 1872, was being crafted by generally incompetent lawmakers, who even when well intentioned, had a habit of making things worse. ${ }^{52}$ The problems, from the General Agents perspective, were numerous. State legislatures created multiple offices of educational oversight, without a clear plan as to how they related to each other, nor to the local agencies actually delivering education. With multiple masters and no clear understanding of who held authority, local school boards made impractical or

${ }^{50}$ Ibid.

${ }^{51}$ Ibid.

${ }^{52}$ Trustees of the Peabody Education Fund, Tenth Meeting of the Trustees (1872), 285. Reprinted in: Trustees of the Peabody Education Fund, Proceedings of the Trustees of the Peabody Education Fund From Their Original Organization (Boston: John Wilson and Son, 1875). 
shortsighted decisions in an attempt to appease state regulators. Often the legislation authorizing local education taxes was vague or poorly written, resulting in never ending litigation by those opposed to public education. In states where the legislature deferred education to local control - in theory a good development from Sears' perspective - the duty to organize school districts was delegated to County Commissions, who regularly failed to act at all. When new districts were organized, either through appointment or election, it was not uncommon for school district Trustees to be incompetent or hostile to public education as there were few, if any, requirements for serving in those positions. And as was common with all forms of tax revenue during the period, collection was guaranteed, disbursal was not, and districts found themselves regularly running deficits even though more than enough funding was collected. ${ }^{53}$ "Thus the public schools may languish, or be suspected, for want of proper administration, even where the law had made ample provision for them," Sears informed the Board, "every one of the disorders here named, and other of like character, have occurred during the year just closed." 54 Though the ground was shifting, Sears and the Trustees would not idly sit. Much of the organization's operations remained the same, however, in recognition of some of these changes, grants began, in some locations, to reflect the necessity of influencing entire state systems of public education.

In North Carolina, Sears discovered a state that was more or less neutral on the issue of public schools. In correspondence with the State's Superintendent of Schools he learned that the North Carolina Supreme Court ruled their state-wide tax for education

\footnotetext{
${ }^{53}$ Ibid., 285-286.
}

${ }^{54}$ Ibid., 286 
unconstitutional. The state legislature decided not to respond, resulting in no additional revenue for education. County Commissions with public education systems generally used the existing local taxes earmarked for education for other purposes. Leaving the public school system in the state being dramatically underfunded in 1871. In 1872 a schools bill was working its way through the legislature leading to the State's Superintendent providing input concerning oversight mechanisms. Since so many of the schools in significant population centers in the state received funding from the Peabody Fund - and those schools were required to report to the Fund specifics about the number of students served and the quality of the education received - he determined to utilize the same measures for the state's oversight efforts. ${ }^{55}$ The impact of the Fund's support in the state was echoed by the Superintendent of Education in the town of Newbern, reporting to Sears that "with the valuable aid your donations have rendered...in the past, we have been able to take and maintain a first-class position for our school. All opposition has been overcome, and partisan private schools have been compelled to succumb." ${ }^{\prime 56}$ While the state system of education remained unstable in North Carolina, there was hope to a resolution. Sears renewed the donation to Newbern of $\$ 1,000$ based on their progress and student population..$^{57}$ More importantly, he determined to maintain the organization's traditional approach to North Carolina to help buoy a teetering system..$^{58}$

South Carolina, however, presented a different set of circumstances, with a divergent outcome. An important key to the Fund's effective use of its resources was the

${ }^{55}$ Ibid., 298.

${ }^{56}$ Ibid., 298-299.

${ }^{57}$ Ibid., 299.

${ }^{58}$ Ibid., 298. 
relationship Sears was able to develop with educational leaders throughout the South. With open and honest communication - reflective of the fact that Sears made correspondents feel like partners in a grand effort rather than beggars - the General Agent gathered vital intelligence, even when the news was negative. Like North Carolina, the Superintendent of Schools in South Carolina shared an honest assessment of the conditions of the state's attitude toward public education in 1871 . He reported that there were any number of challenges, but "they could be soon removed if the two great practical obstacles could be overcome: 1 . The deplorable condition of our finances; 2 . The incompetence and carelessness of school officers." 59 For example, when the state legislature failed to transmit tax revenue collected for education, the South Carolina Board of Education, rather than vigorously advocating change, merely relayed to legislators that the public school system could not survive repeated budget shortfalls. In response to these challenges, with no apparent path forward or vigorous advocate of public education at the forefront, Sears limited the Fund's grants to two schools, for a total of $\$ 800 .{ }^{60}$ North Carolina, facing a similar situation but with a brighter outlook, received more than $\$ 5,000 .{ }^{61}$ In 1872 Texas faced a similar set of circumstances, except there the charge against public education was led by the state legislature who ended public financing. In that case, Sears, in consultation with a number of leading voices in the state, ended the Fund's support of all schools. ${ }^{62}$

${ }^{59}$ Ibid., 302.

60 Ibid., 302.

61 Ibid., 301

62 Trustees of the Peabody Education Fund, Eleventh Meeting of the Trustees (1873), 383. Reprinted in: Trustees of the Peabody Education Fund, Proceedings of the Trustees of the Peabody Education Fund From Their Original Organization (Boston: John Wilson and Son, 1875). 
In Tennessee, Sears took a novel approach. The state faced many of the same challenges as North and South Carolina, but Sears was happy to report to the Board that "during the past year a reaction has commenced, with prospects of complete success," which for the Peabody Fund would result in a fully funded, stable, public education system. To get to that point, the advocates of public schools needed a little help. The Tennessee Teachers' Association, which took the lead in advocating for a fully funded system, made a special request to Sears: a grant of $\$ 1,500$ allowing the association to hire a General Agent tasked with traversing the state and taking a survey of the conditions of education. Armed with information the association believed they could recommend a strategic state-wide system of public education to a newly pliable state legislature. ${ }^{63}$

By modern measures, this arrangement reeked of conflict of interest. As Sears explained to the Trustees, a member of that body also served as President of the Tennessee Teachers' Association. For the General Agent, however, that existing relationship made this a perfect opportunity to intervene in a way well outside of the Fund's standard operations. Since the suggestion came from the association, at the encouragement of a Peabody Fund trustee, who was himself a Tennessean, Sears felt that they could avoid any accusation of attempting to impose its will or political agenda on a state - more than anything else this concern occupied his thoughts about all interactions and funding decisions. Furthermore, with a trustee at the helm of the funded organization, cash could be transferred with the utmost confidence it would be expended as intended. Sears fulfilled the request and the association's plan was set in motion. In fact, the new Agent was so well respected he was named the Assistant State Superintendent of

${ }^{63}$ Tenth Meeting of the Trustees (1872), 324-325. 
Education while completing the survey. The report compiled, while providing a clear view of the deficiencies of the public education system, also read as if it had been written by Peabody himself. It offered that "education has become absolutely indispensable to the material prosperity of every community." ${ }^{64}$ For the Tennessee Teachers' Association, like the Peabody Fund, public education was a corollary of the market economy. The following year, as a result of the survey compiled through the financial support of the Fund, the Tennessee state legislature requested the Teachers' Association draft a universal public education bill. Their proposal changed slightly throughout the legislative process, but made it to the finish line essentially intact. It passed overwhelmingly and was signed into law in $1872 .{ }^{65}$

Even with the changing political landscape throughout the South in 1871, Sears reported to the Board that he authorized the disbursement of $\$ 141,350$. By his estimate, those grants resulted in local support for public schools of approximately $\$ 700,000 .{ }^{66}$ Clearly the Fund's investments were producing results.

While developments at the state and local level were continual challenges to the Peabody Fund's vision of universal free public education throughout the South, from the General Agent's vantage point the real crisis to their mission resided in the halls of Congress. In 1874, with Reconstruction under threat due to local conditions and electoral setbacks throughout the South, Radical Republicans sought to make permanent change to

${ }^{64}$ Ibid., 326.

${ }^{65}$ Eleventh Meeting of the Trustees (1873), 389.

66 Tenth Meeting of the Trustees (1872)., 331. 
the social fabric of the former Confederate States. Their idea, while simple, was also revolutionary: mandatory integration in public education.

Sears began his report to the Board much like he did previous years, with a birds eye view of their operational landscape. "The period of fifteen months which as elapsed since out last meeting has been one of signal success," though qualifying his statement by noting progress was largely confined to "some of the more northernly States." ${ }^{97}$ In the Deep South, he reported, "no ground has been lost, except in two or three, which have suffered not a little from political disorders and popular violence." ${ }^{68}$ Yet, he felt that even in those places in which public education was experiencing a setback, the people remained "imbued with the doctrine of free schools; and nothing in the future is more certain than the acceptance of that principle by the people at large," but only if "they are left to act without unwelcome influences from abroad." ${ }^{99}$ Or more directly, without Congress attempting to force integration on people just coming around to the idea of publicly financed education. Sears was certain, after years of collecting intelligence from the South regarding attitudes toward public education, "that any interference with the schools of these States would be disastrous... and would be by far the most unfortunate to the dearest interests of education...for that class of citizen in whose behalf..." the law was passed. ${ }^{70}$ The General Agent firmly believed that passage of this law would result in a cascade of negative reactions, especially for African Americans.

${ }^{67}$ Trustees of the Peabody Education Fund, Twelfth Meeting of the Trustees (1874), 404. Reprinted in: Trustees of the Peabody Education Fund, Proceedings of the Trustees of the Peabody Education Fund From Their Original Organization (Boston: John Wilson and Son, 1875).

${ }^{68}$ Ibid.

${ }^{69}$ Ibid., 404-405.

${ }^{70}$ Ibid., 405. 
Negative consequences could be avoided. But the level of intervention required of the national government to achieve the goal - the integration bill, followed by a law requiring states to establish, maintain, and fully fund public education, and then a bill making attendance compulsory for white children - seemed unlikely to the General Agent. The three laws needed to implement the intent of the plan highlighted problems the Fund was already encountering in the South. "The greatest obstacle now to be overcome in maintaining free schools," Sears informed readers of The Atlantic in a guest editorial, "is the deep-seated aversion to taxation prevalent among the people..." of the South. ${ }^{71}$ So great was the negative view of taxes, Sears contended, that even "taxes for promoting the general good, which are borne cheerfully in some parts of the country, would be regarded as oppressive here."72 The Southern conception of taxes, combined with a weak economic foundation, meant that even in the places in which public education was supported, funds fell short of needs. This was what made the work of the Peabody Fund so powerful. The organization did not just close the budget gap of many a school district, but it also inspired local communities to figure out how to stand on their own financial feet by accepting taxation as an essential element of collective community action. ${ }^{73}$ This acceptance was happening in numerous communities throughout the South where Peabody cash flowed; for example, Richmond, Virginia in that same year reached the point of self-sufficiency. ${ }^{74}$

\footnotetext{
${ }^{71}$ Ibid., 406.

72 Ibid.

${ }^{73}$ Ibid., 407

${ }^{74}$ Ibid., 415.
} 
Richmond was also instructive of the consequences of compulsory integration. The system of schools created their since the end of the Civil War, consisting of fifty-two schools serving more than 2,400 students, with an annual budget over $\$ 15,000$, provided quality, free education to both white and black students. From the General Agent's perspective, the system built in Richmond worked; regardless of integration or segregation it resulted in equal access to education. (He makes little mention in reports as to comparative quality among segregated schools in segregated public school systems; his defenses of segregation as a local cultural byproduct should not be given too much weight. They were a means to the Peabody Fund's ends, where seen as necessary to garner public support.) If forced to integrate, Sears' predicted, the system would be defunded, white students would return to private schools, and "upon no part of the community would the threatened calamity fall so heavily as upon the colored people. Others can without any personal sacrifice return to the old system of private schools," but black students would, "of course, be left to grow up as ignorant as brutes." 75 It would be fair to assume that Sears viewed integration as a negative for cultural reasons. But he specifically avoided being tied to an agenda on this issue - providing funding for segregated schools and integrated schools alike. His disbursements for schools serving only African American students were smaller than whites only schools; predicated by the belief that black teachers could be secured for less than white teachers. A strong sense of economy overrode any bent toward equality. ${ }^{76}$

${ }^{75}$ Ibid., 409-410.

${ }^{76}$ To be fair, he also encouraged the employment of female over male teachers for the same reasons. 
For Sears, this national integration effort represented a danger, "which threatened the destruction of the State system of free schools in the South, in all of which provision is made for the education of one race as much as the other." 77 With some sympathy in his tone, regardless, Sears sprang into action, unable to "remain a passive spectator, while men in power were unwittingly...urging on a measure which, if carried out, would undo nearly all that [we] have done at the expenditure of so much treasure and assiduous labor."78 Sears began a full court press, reaching out in private to every member of Congress with whom he shared a connection, and arranging to testify against the bill before two committees. Ultimately, even some of the most radical members of the Republican caucus were swayed by his argument. The bill failed to escape committee; the mission and work of the Peabody Fund in the past was protected from this intrusion. Sears work could continue fruitfully.

After six short years, following the game plan developed with George Peabody, Barnas Sears turned the Peabody Education Fund from an idea to a catalyst for the corporatization of American education. Through taking the view of an investor utilizing their resources to create specific outcomes, while emphasizing a corporate culture both for their organization and those receiving funding, Sears was able to make a significant, real, and immediate impact on the landscape of education in the South. Even the interest in education from the founder, the Trustees, and the General Agent was in furtherance of the market economy expanding and stabilizing in the former Confederate states. Much

\footnotetext{
${ }^{77}$ Ibid., 405.
}

${ }^{78}$ Ibid. 
like for-profit corporation of the period (and today), Sears was not afraid to push the Fund's agenda in the body politic - though quick to avoid controversy that poised a threat to their desired outcomes. The system implemented by Sears remained largely intact until his retirement in 1880, and though tweaked by the next General Agent, guided the operations of the Fund until its disbandment in 1915. So impactful was the culture of corporatization in support of the market economy created by Sears, that when the Slater Fund failed to establish its own corporate culture, they turned to his successor to lead the way. 


\section{Chapter 5}

The John F. Slater Fund

As it became clear that the man selected as General Agent of the Slater Fund was not meeting the expectations of the Trustees, letters went back and forth discussing the matter. One such Trustee, after expressing frustration with the man, resigned himself to the situation, dashing off a thought: "we must accept him for what he is." ${ }^{\text {Conflict }}$ between the hired executive of a nonprofit corporation and the Board is nothing new. What is unique in this case is that the man who served as president of the Board of Trustees, from its creation until his death in 1893, was former United States President Rutherford B. Hayes. His status as a former president, and his penchant for retaining correspondence, offers a unique view onto the inner workings of this nonprofit corporation. It did not, like the Peabody Foundation, provide services directly, instead making investments in education through grants to other institutions. In many ways, being one step removed from the action, gave those associated with the organization more time to be strategic, but also more time to contemplate, worry, politic, and question. Here was a nonprofit corporation struggling, usually against its one paid staff person, to maintain the structures, procedures, policies, and expectations of a corporation. The story that unfolds is an important one; it demonstrates the degree to which corporatization became an expectation within the field of charity. Even in the choice of what to

${ }^{1}$ Daniel Coit Gilman, "Daniel Coit Gilman to Rutherford B. Hayes Oct. 19, 1889" Teach the Freeman: The Correspondence of Rutherford B. Hayes and the Slater Fund for Negro Education, 1881-1887 (Baton Rouge: Louisiana State University Press, 1959), Vol. II, 79. 
financially support, the Slater Fund not only expected specific outcomes and measurable data, but used its resources to further the free market system. The work would be on behalf of African Americans in the South, but the form and structure taken, left many decisions to be made. With Hayes' passing, the window onto the inner workings of this organization shrunk to annual reports. But, in its early story, the relationship between charity and corporatization comes into focus.

When John F. Slater, a wealthy businessman and philanthropist, determined to address the cause of education for African Americans in the American South, he looked to the model of the Peabody Foundation. But these entities were still developing, and though he understood the general form and function of a foundation, and the mission he wanted the organization to pursue, much was left to be determined.

With failing health, Slater felt the immediacy of his legacy pressing in on him, and turned to his stalwart friend, Leonard W. Bacon - a well-known and controversial pastor - to help set his plans in motion. Bacon, for example, tackled the most pressing initial matter, contacting and recruiting the men charged with overseeing the organization. While Slater provided the vision and funding for the organization, part of his goal was creating a foundation free of his influence and able to adjust to the times; Slater sought voices of independence, competence, and influence for the Trustees. With his reputation and connections for Bacon to trade on, the pastor was able to assemble a veritable who's who of Americans in support of educational opportunities for African Americans, from the highest reaches of government, business, education, and religion: Morrison Waite, Chief Justice of the United States Supreme Court; William Dodge, New 
York businessman and philanthropist; Phillip Brooks, rector of Boston's famous Trinity Church; Daniel Coit Gilman, the president of Johns Hopkins University; Morris Jesup, New York financier and philanthropist; and William Slater, John F. Slater's son and heir to his fortune. ${ }^{2}$ But by far the most famous and influential of the Trustees, and the man selected to lead the organization as the president of the board, was Rutherford B. Hayes. Ironically, Hayes, while serving his single term as President of the United States, ended the occupation of southern states by federal troops following the Civil War, creating the political condition by which traditional forces in the south could impede the progress of the freed peoples. This made the mission of the Slater Fund more challenging.

Immediately after making his intentions clear, through the letters of Bacon to potential trustees, Slater's dream ran into challenges. By investing the initial donation, and limiting bequests to only dividends and interest - projected at $3.5 \%$ annual - the Trustees foresaw an annual budget of a paltry $\$ 35,000 .^{3}$ There was also the issue of where to charter the Fund. With the tax exempt non-profit organization having yet to become a standard form of corporate entity, Slater was concerned that New York, for example, would tax the Fund's income. He wondered if seeking a charter in Connecticut would not better protect the Fund's assets from taxation. Bacon, suggesting that the winds of change within a state legislature are hard to predict, offered that a national charter might be more consistent. Bacon offered that, unlike a state, the "... National

${ }^{2}$ Bacon was also offered a seat on the Board, but declined. He did not want his tendency to say controversial things to steal attention from the organization or give others an unfounded negative opinion of the Fund.

${ }^{3}$ Leonard W. Bacon, "Leonard W. Bacon to Rutherford B. Hayes, Oct. 10, 1881," Teach the Freeman: The Correspondence of Rutherford B. Hayes and the Slater Fund for Negro Education, 1881-1887 (Baton Rouge: Louisiana State University Press, 1959), 3-4. 
Legislature could never be indifferent to a National charity." ${ }^{4}$ Slater was also concerned that the Fund, beginning with a gift of $\$ 1,000,000$, and only expending the profit acquired from investment of the principal, would sustain the organization in perpetuity - a distinct possibility he wanted to disrupt from the beginning. Slater himself proposed the fund could eventually be converted into a college if the board determined it was needed. ${ }^{5}$

Wanting to launch as quickly as possible, Slater began to push to have the funds transferred to the Trustees, even prior to the Slater Fund becoming a legal entity. Bacon and Slater consulted Simeon Baldwin, a law professor at Yale University, who was gaining notoriety as an expert in the emerging field of Corporate Law, and he advised against making any transfers prior to being chartered. He presented to Slater two important points: first, "the Legislature will find a motive for granting favorable terms in order to secure a large gift to public charity," which they might not if the funds were already in their hands; second, "if the Charter is granted first \& the gift then made in view of its immunities \& exemptions these become binding on the State with the force of a contract." ${ }^{\circ}$ This view was informed by the precedent set in Dartmouth College v. Woodward (discussed in the introduction). On that legal foundation, Bacon noted, the charter and the donation would "stand as long as the U.S. Constitution does. In the other case, they would be repealable at the caprice of the Legislature." " Ultimately, to meet the desire of Slater to see the organization created and funded prior to his death, they decided

\footnotetext{
${ }^{4}$ Leonard W. Bacon, "Leonard W. Bacon to Rutherford B. Hayes, Oct. 26, 1881," Teach the Freeman (Baton Rouge: Louisiana State University Press, 1959), 8-9.

5 Ibid., 8-9.

${ }^{6}$ Leonard W. Bacon, "Leonard W. Bacon to Rutherford B. Hayes, Jan. 18, 1882" Teach the Freeman (Baton Rouge: Louisiana State University Press, 1959), 28.

${ }^{7}$ Ibid.
} 
to charter the Fund in New York. The Peabody Foundation, for which the Slater Fund takes much inspiration, was chartered in New York as well, and able to receive a special tax dispensation. New York state, as a matter of law, limited the size of tax exempt entities; with a minimum initial donation of $\$ 1,000,000$ the Slater Fund would have have found much of its income being taxed. ${ }^{8}$ While it was not clear from the outset if the organization would be granted an exception, the New York legislature consented to the request.

With the decision made to seek a charter in New York, the question of how to invest the organization's funds once again took center stage. Maximizing their return would mean more cash year-to-year for investment in African American education. Maximizing returns also meant maximizing risk. Though Slater purposefully created an organization independent of his leadership, rather than donating $\$ 1,000,000$ cash, he donated a carefully selected portfolio of investments instead. One such holding were bonds in one of America's many emerging railroads, with a guaranteed $6 \%$ return. Guaranteed, of course, so long as the railroad did not fail - a common trend in the volatile world of railroad financing. While the Trustees were free to liquidate these investments, through the board presidency of Hayes, they remained as Slater provided.

This did not mean that Hayes and the other trustees were not concerned about the status of their holdings. During a significant railroad downturn in 1882, Hayes wrote Morris Jesup, who was selected as the Treasurer of the organization, regarding their financial luck. The New Albany, Louisville, and Chicago Railroad bonds, a large chunk

${ }^{8}$ Leonard W. Bacon, "Leonard W. Bacon to Rutherford B. Hayes, Mar. 15, 1882" Teach the Freeman (Baton Rouge: Louisiana State University Press, 1959), 30. 
of Slater's donation to the Fund, survived unscathed. Hayes, rather than taking comfort in that news, reflected on their investment strategy. "I trust that in future no bonds will be purchased except those of strictly first-class RRs whose payment of dividends are regularly made." "The investments made of trust funds," Hayes explained to Jesup, "stand on very different footing from individual investments." ${ }^{10}$ When the individual invests, Hayes stated, they invest their excess funds. But, "a trust fund has no surplus. We are to look for hard times to occur frequently during the lifetime of our trust, when at least three-fourths of all the RRs of the country will fail to pay their interest." ${ }^{11}$ Hayes cautioned Jesup, "our investments we must hope, will be made exclusively in the securities of the remaining fourth which will continue to pay." Perhaps recognizing that he was lecturing a man who made a fortune in finance, Hayes ends with an apology, acknowledging that the Fund's finances weighed on his mind. ${ }^{12}$ While financial concerns captured much of the board's energy, the actual mission of the organization remained less defined than it appeared.

When Slater initiated his Fund, the focus was clearly on African American education in the South. But as the discussion about providing the funds prior to the creation of a charter makes evident, the creation of a nonprofit corporation - and by default its stated mission - becomes a form of contract. Therefore, the purpose of the organization as presented in the charter, even in the late nineteenth century, was central to maintaining its status as a tax exempt entity. In crafting the charter proposal its authors

\footnotetext{
${ }^{9}$ Rutherford B. Hayes, "Rutherford B. Hayes to Morris K. Jesup, Nov. 23, 1882" Teach the Freeman (Baton Rouge: Louisiana State University Press, 1959), 75.

${ }^{10}$ Ibid.

11 Ibid.

12 Ibid., 75-76
} 
made a number of changes to widen the potential purview of the Fund. The first aspect of the mission to be removed, somewhat bizarrely, was the word 'colored.' As Bacon explained to Hayes, "while giving the same immediate direction to the charity, [the Directors] have left a margin of future possibility in favor of Mormon, New Mexican, Indian, \& whatever neglected children it may please God to give in charge to us." ${ }^{13}$ Next was the word 'Protestant.' 14 Though references to Christianity remained, the specific type of Christianity became undefined. This did, however, give pause to J.L.M. Curry, the General Agent of the Peabody Foundation, when he reviewed the charter. In a letter to Hayes, Curry commented that he feared "the limitations of education by the word, “Christian," will give you trouble - our public schools do not give "Christian" education, even when the bible is used in them." ${ }^{15}$ Reflecting his experience as the representative of a foundation, but also a southerner who spent a lifetime in education, Curry continued, "if you are shut out from public schools... will you not perforce be required to establish schools" or an even more provocative possibility, "aid individual enterprises? In the latter case what guaranty of permanent results? Men $\&$ individual enterprises die; States do not." 16 So strong were Curry's concerns he even asked if Hayes could "not get Mr. Slater so to interpret the gift as to relieve you from what may be a serious embarrassment?"17 Clearly, the experienced Curry was worried that the new Fund was about to paint themselves into a corner through inexperience and a lack of mission clarity.

${ }^{13}$ Bacon, "Leonard W. Bacon to Rutherford B. Hayes Nov. 26, 1881," 17.

${ }^{14}$ Ibid., 18.

15 J.L.M. Curry, "J.L.M. Curry to Rutherford B. Hayes Jul. 8, 1882" Teach the Freeman (Baton Rouge: Louisiana State University Press, 1959), 47.

${ }^{16}$ Ibid., 47-48.

${ }^{17}$ Ibid., 48. 
Hayes was more confident, "touching the phrase "Christian Education," I trust we shall find no embarrassment on that account." ${ }^{18}$ He explained to Curry, "If we educate pupils in the School or college of any Christian denomination it may well be termed a Christian Education." 19 Furthermore, since the students would probably be older than traditional students, and needing specific education or training, that requirement could be met by "... requiring him to seek religious training and instruction in the churches and Sunday School of the place where he may happen to be?"20 Given that the Fund was specifically not interested in providing support to individuals, but instead to institutions, Hayes may have been offering solutions with little hope of implementation or value to the mission. Perhaps recognizing that, he concluded, "I hope in some such way to escape the trouble you anticipate," and then asked Bacon to clarify this issue with Slater. ${ }^{21}$

Bacon's response to Hayes, though not officially part of the charter, was enough to settle the matter in Hayes' mind. "I can assure you with confidence," Bacon began, "that the phrase "Christian Education" is to be taken in the largest and most general sense." ${ }^{22}$ He offered further clarification, stating that Slater was receiving pushback on his fund from members of the congregation he attended, a Unitarian church in Boston, as they were worried the language of the charter "might devote the fund to theological \& sectarian competitions." ${ }^{23}$ Given the wide range of people who raised questions about this

18 Rutherford B. Hayes, "Rutherford B. Hayes to J.L.M. Curry Jul. 15, 1882" Teach the Freeman (Baton Rouge: Louisiana State University Press, 1959), 50.

${ }^{19}$ Ibid.

20 Ibid.

21 Ibid.

${ }^{22}$ Leonard W. Bacon, "Leonard W. Bacon to Rutherford B. Hayes Jul. 21, 1882" Teach the Freeman (Baton Rouge: Louisiana State University Press, 1959), 52.

${ }^{23}$ Ibid. 
aspect of the charter, it would seem to be an honest concern. Slater, however, "answered that, in the sense which he intended, the common-school teaching of Massachusetts \& Connecticut was [Christian] Education - that is, it is leavened with a predominant \& salutary Christian influence." 24 According to Bacon, Slater was certain there was "no need of limiting the gifts of the Fund to denominational institutions. It may often \& easily happen that the more definitely denominational a school is, the less really Christian." 25 Furthermore, reflecting Slater's desire that the Fund be flexible and responsive to developments, "If the Trustees should be satisfied that at a certain State institution their beneficiaries would be surrounded with wholesome influences, such as would tend to make good Christian citizens of them," Bacon explained, "there is nothing in the use of this phrase to hinder their sending pupils to it, even past the door of a more "professedly religious" institution." 26 This was all the clarification Hayes and the Trustees needed on this matter; the issue of 'Christian Education' did not come up again, at least while Hayes served as president of the Board of Trustees.

The one issue the charter firmly resolved was the lifespan of the organization. As discussed previously, Slater was concerned that the Fund could exist into perpetuity. And while his aim was to make a significant impact, permanence was not part of his vision. Bacon, giving voice to Slater's concerns in communications with Hayes, provides his thinking: "He thinks (rightly) that there is small chance that the negroes will cease to need provision or ordinary schooling within one generation, or two." ${ }^{27}$ As such, the

\footnotetext{
24 Ibid.

25 Ibid.

${ }^{26}$ Ibid.

${ }^{27}$ Leonard W. Bacon, "Leonard W. Bacon to Rutherford B. Hayes Oct. 26, 1881," $8-9$.
} 
"present destination" of the funds "should cease to be useful." 28 The initial idea circulated among the potential Trustees was that eventually the Fund would become a university. But Slater was cautioned by confidants at making this a requirement as the nation seemed to birthing new institutions of higher education at a record pace and demand could be limited. ${ }^{29}$ Instead, Slater determined that after thirty three years if the Trustees found "a change in social conditions" then the Trustees could disband the Fund with a two-thirds vote. ${ }^{30}$ At that point the Fund could place its assets under the direction of an existing college. ${ }^{31}$ With many of the questions regarding how the Fund would be managed resolved - or at least resolved in the minds of the founding Trustees, Slater, and Bacon all that was left was distributing funds. How to go about that, however, led to even more questions and fewer certainties.

With the corporate foundation of the Fund in place - the charter in hand, a notable Board of Trustees, and a dependable investment vehicle selected - all that was left was to meet the mission. After almost two years of deliberation and planning it seemed that execution would be simple. But where to distribute funds, how to evaluate the recipients, and who would do the bulk of the work, though less important than determining the mission of the organization, were vastly more complicated. It would reveal a clash of cultures. The corporate impulses of the men selected for the Board of Trustees quickly conflicted with the romantic notions of the man selected to guide the Fund's educational

\footnotetext{
${ }^{28}$ Ibid., 8.

${ }^{29}$ Ibid., 9.

${ }^{30}$ Ibid.

${ }^{31}$ Ibid.
} 
investments. Again, Hayes turned to Bacon for a sense, informed by Slater, of how to proceed.

In a May $5^{\text {th }}, 1882$ letter to Hayes, Bacon presented, in some detail, how he felt the Fund should begin its work. From his perspective there were two issues that needed to be addressed: the policy of what and why to fund educational endeavors, and who should be hired as the General Agent of the Fund to guide grants and evaluate efficacy. ${ }^{32}$ Bacon's hope was "that the fund may not lie still long enough in one place to let people or institutions lie down on it," while not being afraid of taking risks. ${ }^{33}$ With the freedom to experiment, take risks, and even potentially fail voiced by the emissary of the founder, Bacon next addressed the issue of expenses. "Mr. Slater's first idea was that the income of the fund should simply be dispensed as dole, form year to year, to the most deserving institutions engaged in the work. ${ }^{34}$ In his initial vison, this would be executed by an agent "already in the field for other work, [who] could give part of his time to this business, for a moderate compensation, and so almost the entire income go to the work of the charity. ${ }^{" 35}$ But as Bacon opened his remarks, when asked to comment on the role and person selected for Agent, and the policy for distributing funds, "a mistake in the policy is much easier corrected than a mistake in the man." ${ }^{" 36}$ Anyone can distribute funds, but doing so knowledgeably, and assessing the effectiveness of the programs supported, required then, as now, a unique skillset.

${ }^{32}$ Leonard W. Bacon, "Leonard W. Bacon to Rutherford B. Hayes May 5, 1882" Teach the Freeman (Baton Rouge: Louisiana State University Press, 1959), 38.

${ }^{33}$ Ibid.

${ }^{34}$ Ibid.

${ }^{35}$ Ibid.

${ }^{36}$ Ibid., 36. 
Over the course of approximately six months, the Trustees, and the people connected with the Trustees, offered several candidates for the role of General Agent. It did not take long for one man to rise to the top of the list. "I hope that the name of Dr. Haygood (author of "Our Brother in Black") will be seriously considered," Bacon wrote to Hayes. ${ }^{37}$ Haygood was an active and well regarded pastor of the Methodist church, and more importantly for his candidacy as General Agent, a renowned educator and president of Emory University. ${ }^{38}$ Bacon, voicing a position held by a number of the Trustees, offered to Hayes that he did not "dare, on so slight an acquaintance, to say that he is the right man for the place; but he certainly has some great qualification, \& I do not know of any drawbacks." 39 And seeing the potential for claims of carpetbagging in the Fund's future, Bacon also recommended selecting a Southerner, which the Georgian Haygood would fulfil. ${ }^{40}$ When Hayes asked Curry for his thoughts on Haygood, he was equally positive, but again acknowledged he did not him personally. His reputation as "a broad \& catholic Christian \& patriot," combined with his authorship of Our Brother in Black, which showed "courage, ability and right opinions on the Negro Problem," making him the best candidate for the post. ${ }^{41}$ And William Dodge, a Trustee, offered that he had not yet met Haygood, but had exchanged letters with him for some time, and held his full

${ }^{37}$ Leonard W. Bacon, “Leonard W. Bacon to Rutherford B. Hayes May 5, 1882," 37.

${ }^{38}$ Frederick V. Mills, “Atticus G. Haygood (1839-1896), New Georgia Encyclopedia.

${ }^{39}$ Leonard W. Bacon, "Leonard W. Bacon to Rutherford B. Hayes May 5, 1882," 37.

${ }^{40}$ Ibid.

${ }^{41}$ J.L.M. Curry, "J.L.M. Curry to Rutherford B. Hayes Jul 17, 1882" Teach the Freeman (Baton Rouge: Louisiana State University Press, 1959), 51. 
support for the position. ${ }^{42}$ Prior to being selected, Haygood met with the Board of Trustees, but by then it reads more as a foregone conclusion than an interview. Almost immediately, observers of their correspondence are left with the feeling that the Trustees wished they became more familiar with Haygood prior to hiring him. His tenure as General Agent did not go particularly well - unlike the men who provided oversight of the organization, Haygood was not well suited for the corporate nature of the John F. Slater Fund.

The first sign of trouble on the horizon came even prior to Haygood's selection as General Agent. Bacon predicted that Haygood would be reluctant to leave Emory, and would perhaps take a leave of absence for a few years rather than leaving his post. ${ }^{43}$ Haygood himself, rather than seeing remaining at Emory as a conflict of interest, viewed holding both positions as a positive. "I do not think that it would be right for me to sever my connection with Emory College. My relationship to the College is (at least as it appears to me) providential." ${ }^{44} \mathrm{He}$ assured Bacon that "it is clear to me that I can do the work that will be wanted in the agency and retain a useful connection here. Moreover - it is equally clear to me that my connection here would be an immense advantage to the other interest." ${ }^{\prime 45}$ As can be imagined, the Trustees found this a less than opportune arrangement.

${ }^{42}$ William W. Dodge, "William E. Dodge to Rutherford B. Hayes Aug 8, 1882, Teach the Freeman (Baton Rouge: Louisiana State University Press, 1959), 57.

${ }^{43}$ Leonard W. Bacon, "Leonard W. Bacon to Rutherford B. Hayes May 5, 1882," 38.

${ }^{44}$ Atticus G. Haygood, "Atticus G. Haygood to Leonard W. Bacon, Jan. 25, 1882” Teach the Freeman (Baton Rouge: Louisiana State University Press, 1959), 67. ${ }^{45}$ Ibid. 
Haygood, slyly, made a counteroffer. His primary hesitation in leaving Emory lay in his unfulfilled efforts to expand cheap housing options for the students financially stretched by pursuing higher education. If, there was only some way he could secure a donation for $\$ 6,700$, which would provide housing for 70 young men at a reasonable monthly cost. Without worrying about room and board, these scholars could focus solely on their education, which was Haygood's greatest desire. ${ }^{46}$ Haygood's unstated point was clear: for a donation to complete this work, the preacher would leave Emory for the Fund. Slater the man, rather than the Fund, made the contribution to Emory, and Haygood accepted the post of General Agent. ${ }^{47}$ This would be just the first of many times that it became clear that Haygood's focus was not singularly on the operations of the Fund.

At the root of the Fund's challenge with Haygood was a matter of perspective. For the long-time educator, evaluating the effectiveness of programs, determining what schools to fund and which to pass over, was an intellectual exercise, a romantic fantasy about influencing the cultural elite to take up the cause of education for African Americans, and a religious calling. For the gentlemen of the Board of Trustees, influencing and lobbying on behalf of the cause was important, but not nearly as important as estimating the return on their educational investments. They expected donations to be based on something measurable. And they expected the outcome of those donations to be measurable. But neither the Trustees nor Haygood expressed their expectations in direct ways until much later in their relationship. Even then, late in his

${ }^{46}$ Atticus G. Haygood, “Atticus G. Haygood to Rutherford B. Hayes Aug 31, 1882" Teach the Freeman (Baton Rouge: Louisiana State University Press, 1959), 63-64.

${ }^{47}$ Rutherford B. Hayes "Rutherford B. Hayes to Atticus G. Haygood Aug 24, 1891" Teach the Freeman (Baton Rouge: Louisiana State University Press, 1959), Vol. II., 207-208. 
tenure, Haygood lamented, "if I only knew what is wanted I would faithfully try to do it." Instead, simmering conflict built on a foundation of unfulfilled expectations is present in their correspondence.

Haygood's first monthly report to the Board of Trustees was a solid example of this misunderstanding. "I have occupied myself during the month of November in gathering information touching the matter committed to me," Haygood reported to Hayes, "this I have done by personal interviews with persons in position to give me reliable information and by correspondence." 48 He concludes with an optimistic statement, "I may claim to have made encouraging progress." 49 That is, literally, the totality of his report on one month's work. Hayes passed the report along to Daniel Coit Gilman, secretary of the board, commenting that "It is short and merely formal... as it is so merely a formal compliance with the rule, I do not send it to other members of the Executive Committee." ${ }^{50}$ Gilman replied to Hayes, "Dr. Haygood's report will not be of much value, if it is simply to be a formality." ${ }^{51}$ The historical record is not clear if Haygood was actually informed that his report was not what was intended in requiring a monthly report (though, at a later date, Hayes clearly discussed the matter with him directly). Over time his reports became more extensive, but seem to have never met their expectations for identifying measurable outcomes, strategic thinking, or even looking like a full month's worth of work.

${ }^{48}$ Atticus G. Haygood, “Atticus G. Haygood to Rutherford B. Hayes Dec. 6, 1882” Teach the Freeman (Baton Rouge: Louisiana State University Press, 1959), 78. 49 Ibid.

${ }^{50}$ Rutherford B. Hayes "Rutherford B. Hayes to Daniel Coit Gilman Dec. 11, 1882, Teach the Freeman (Baton Rouge: Louisiana State University Press, 1959), 79. ${ }^{51}$ Daniel Coit Gilman "Daniel Coit Gilman to Rutherford B. Hayes Dec. 15, 1882” Teach the Freeman (Baton Rouge: Louisiana State University Press, 1959), 81. 
In September of 1883, Haygood reported a delay in getting his report to the board as he was dealing with a Slater Fund related crisis of his own making. After giving a series of speeches on the importance of education for African Americans, Haygood relayed to Hayes that they "raised a tempest." 52 He explained to Hayes that problems arose when "the papers denounced without publishing $\&$ the people got mad about what I did not say. Some of the them about what I did say." 53 The General Agent, clearly believing that defending himself counted as work on behalf of the Fund, "replied by publishing 40,000 copies - I have said nothing else - Wanted them to know that I meant what I said." 54 He continued, by accounting for his time: apparently spending between ten and fifteen hours a day preparing mailings of his remarks. ${ }^{55}$ Perhaps to assure Hayes of the wisdom of this course of action, he remarked "The results are going to be glorious - More real thought has been bestows [sic], in these regions, upon the Negro \& his education - \& his whole case- in the last month than in the last ten years." ${ }^{, 56}$ Returning to the actual work of the Slater Fund, he begged Hays “don't let the Board scold me for my delay. The report will be along next week. It is the first time in my life I have not been ready." 57 This would not be the last time his report was delayed.

Even when Haygood's reports became fuller and more informative, his efforts on behalf of the Fund remained scattered. In his January 1886 report to Hayes, he relayed information of a trip he made to Fisk University and Central Tennessee College. At

${ }^{52}$ Atticus G. Haygood “Atticus G. Haygood to Rutherford B. Hayes Sep. 19, 1883” Teach the Freeman (Baton Rouge: Louisiana State University Press, 1959), 97-98.

53 Ibid., 98

54 Ibid.

${ }^{55}$ Ibid.

${ }^{56}$ Ibid.

${ }^{57}$ Ibid. 
Central Tennessee, he was asked to speak on the importance of African American education; which he assured Hayes' was met with great fanfare in the press. ${ }^{58}$ Consistently leaving a topic on a positive note, as he would do in any number of letters, Haygood remarked, "I believe, but help of God, I can do something to foster right thinking \& feeling among Southern white people." ${ }^{59}$ As Haygood returns to the topic of swaying others as to the importance of supporting African American education again and again, perhaps he found that of more importance than assessing the suitability of schools. ${ }^{60}$ The Trustees, however, disagreed.

Hayes was rarely critical of Haygood. Even when he attempted to steer him in another direction, it was for his benefit, and generally something he asked to remain confidential. Yet, his correspondence is replete with criticism. Gilman, a repeat commenter on Haygood's effort, in working to resolve a miscommunication with the administration of Howard University, remarked that "our General Agent is not as prompt in attending to his correspondence as would be desirable." ${ }^{61}$ Chief Justice Waite, a man who did not often correspond with Hayes, could not help but ask "What has become of Dr. Haygood? I hear nothing of him or his work." 62 Repeatedly boiling up in meetings of

${ }^{58}$ Atticus G. Haygood “Atticus G. Haygood to Rutherford B. Hayes Jan. 13, 1886" Teach the Freeman (Baton Rouge: Louisiana State University Press, 1959), 167. ${ }^{59}$ Ibid.

${ }^{60}$ See the following from Teach the Freeman: The Correspondence of Rutherford B. Hayes and the Slater Fund for Negro Education, 1881-1887 (Baton Rouge: Louisiana State University Press, 1959): "Atticus Haygood to Rutherford B Hayes Jul. 21, 1886," Vol. I, 182; “Atticus G. Haygood to Rutherford B. Hayes Feb. 13, 1887," 198; "Atticus G. Haygood to Rutherford B. Hayes Nov. 25, 1888," Vol. II., 34; and “Atticus G. Haygood to Rutherford B. Hayes Aug. 9, 1887," Vol. II, 207-211 for examples.

${ }^{61}$ Daniel Coit Gilman, "Daniel Coit Gilman to Rutherford B. Hayes Feb. 1, 1884" Teach the Freeman (Baton Rouge: Louisiana State University Press, 1959), 106.

${ }^{62}$ Morrison R. Waite "Morrison R. Waite to Rutherford B. Hayes May 22, 1884" Teach the Freeman (Baton Rouge: Louisiana State University Press, 1959), 108. 
the Trustees, and therefore not recorded candidly, we learn from Haygood is the matter of accounting. At the end of his time with the Fund, after resigning effective at the end of the academic year, Haygood complained to Hayes that, Jesup, the treasurer, via his secretary “...has repeatedly during the year undertaken to lecture \& direct me..."63 Jesup, from Haygood's perspective, “...knows less about the matters we have in hand than any other. The wide scope of the Trust he does not comprehend. He cannot." ${ }^{\prime 4}$ The General Agent, in his consternation over dealing with Jesup, struck upon a truth of his relationship with the Trustees. The board desired nothing more than to alleviate the asymmetry of knowledge they believed existed between them and their employee. As Gilman explained to Hayes, "as I understood the members of the Board, they are not solicitous to have a personal report of how his time is spent," instead, "they would like to be aided in keeping up an intelligent interest in the various important questions which he is called on to consider. $" 65$ The request, made by the Trustees as individuals and as a governing board, directly and indirectly, was to investigate and report on the status of African American education in the South. Haygood repeatedly came up short.

From the first step, Haygood understood that investigation would be an important part of his role. "I am using fairly exhaustive methods to collect information and the field is wide," he report to Hayes, "the subject has never been put into shape for a clear and

${ }^{63}$ Atticus G. Haygood, “Atticus G. Haygood to Rutherford B. Hayes Nov. 28, 1890" Teach the Freeman (Baton Rouge: Louisiana State University Press, 1959), Vol. II., 173.

${ }^{64}$ Ibid.

${ }^{65}$ Daniel Coit Gilman, "Daniel Coit Gilman to Rutherford B. Hayes Oct. 19, $1889, " 79$. 
business like study of the whole matter."66 Though he recognized the need for clear information as a bases of their operations being "business like," he reported only obstacles. "It is not difficult to find what this society says, and the other. But it is harder to find out what they have done" and even where that were possible, he told Hayes, "harder still to find out their method, or lack of it; hardest of all to find out just how they may be helped to the best advantage." ${ }^{97}$ In a letter shortly following, Haygood gave Hayes a window onto his thinking on the topic: "Without saying it I have tried to make the facts say that ours is not the business of an amateur semi-scientific investigating committee." ${ }^{68}$ Yet, that is how the board often felt.

In 1884, two years into Haygood's work with the Fund, Dodge let Hayes know that "Mr. Jesup, Mr. Stewart and myself [all Trustees], agree in the hope that you will be able to arrange to have Dr. Haygood spend a little time in the work and carefully study the industrial [education] system."69 From the General Agent's perspective, he was doing exactly that. Yet, in 1885, much to Haygood's chagrin, the board become more forceful in its call for information. Rather than immediately begin making appropriations for the 1886-7 academic school year, Haygood complained to Hayes, "everything waits the "investigation" so much talked about in January."70 A resolution passed by the board, which from Haygood's seat only served to interfere in the important work of the Fund,

${ }^{66}$ Atticus G. Haygood “Atticus G. Haygood to Rutherford B. Hayes Feb. 1, 1883" Teach the Freeman (Baton Rouge: Louisiana State University Press, 1959), 85.

${ }^{67}$ Ibid.

${ }^{68}$ Atticus G. Haygood “Atticus G. Haygood to Rutherford B. Hayes Mar. 3, 1883 Teach the Freeman (Baton Rouge: Louisiana State University Press, 1959), 88.

${ }^{69}$ William E. Dodge, Jr., "William E. Dodge, Jr. to Rutherford B. Hayes" Teach the Freeman (Baton Rouge: Louisiana State University Press, 1959), 124.

${ }^{70}$ Atticus G. Haygood, “Atticus G. Haygood to Rutherford B. Hayes Mar. 30, 1885" Teach the Freeman (Baton Rouge: Louisiana State University Press, 1959), 139. 
was extensive. It called for the organization of a meeting of the board in which experts in the field of Southern education, beyond just Haygood, would be asked to share their perspectives. It required Haygood to produce a thorough exploration of the status of African American education in one particular Southern state, Georgia. This forced Haygood to be more thoughtful in the information he presented. Specifically, it required data. ${ }^{71}$ Haygood was also required to produce two papers, one providing a broad survey of African American education in the South and the other pulling together the available information regarding industrial education efforts in the North. ${ }^{72}$ From Hayes perspective, "the consultations with our own members, whose minds are dwelling on the Subject constantly, yield to me more that is valuable and suggestive, than any other source of information"73 As much as Hayes questioned the need for extensive structure and data collection, his view did not carry the day. Haygood was left with no option but to comply with the resolution.

This does not mean that Haygood was happy with the situation. In a long letter of protest to Hayes, the General Agent voiced a number of concerns, beginning by stating that "the undertones of the January meeting were to be utterly unsatisfactory. There seemed to be a notion that the chief end of the Slater Board was to study the Negro Question."74 Rather than equating investigation and thorough fact finding as foundational to making an informed investment - whether charitable or for profit - instead he equated

${ }^{71}$ Board of Trustees of the John F. Slater Fund, "Resolution Jan. 18, 1885" Teach the Freeman (Baton Rouge: Louisiana State University Press, 1959), 144.

72 Ibid.

73 Ibid.

${ }^{74}$ Atticus G. Haygood "Atticus G. Haygood to Rutherford B. Hayes May 4, 1885" Teach the Freeman (Baton Rouge: Louisiana State University Press, 1959), 146. 
the board's directives to esoteric studies of the fall of the East India company, the sociology of the West Indies, and in-depth examinations of the Ku Klux Klan. To bring that point to a close, Haygood exclaimed “...such inquiries are for theorists - scientists amateurs. But they are as remote from the business of the Slater Board \& the thought of the dead Prince who gave the money as building the Bartholdi Monument in New York harbor." 75 It is telling, that in his frustration, Haygood conflates as being the same, in terms of their relationship to empiricism, the theorist, the scientist, and the amateur.

His work, rather than being that of the theorist, scientist, or amateur, was the work of a minister. "I am not accustomed, although a preacher - to speak of my faith and religious convictions," Haygood admitted to Hayes, "I believe with all my soul that God's hand is on me for these poor people. It is to me a sacred work. It is the prayer of my days and nights, that I may be faithful.."76 As might be expected from a man of faith, Haygood related that "the main part of my work cannot be reported on or of. I cannot make others see it - I would not care for myself - but I fear that they may be discouraged." 77 Speaking to the almost divine nature of his work, "It is a work that cannot show its results in figures. It seems so slow - but there is no other way. This work must take root in the South - \& in Southern white consciences - Else, some day, it will die." ${ }^{" 78}$ For the Board of Trustees, the actions of the Fund were the application of the strategies of capitalism to charity. For Haygood it could not have been farther from the concerns of the market.

75 Ibid.

${ }^{76}$ Atticus G. Haygood, “Atticus G. Haygood to Rutherford B. Hayes Jan. 12, 1887” Teach the Freeman (Baton Rouge: Louisiana State University Press, 1959), 191. ${ }^{77}$ Ibid.

${ }^{78}$ Ibid. 
Incapable of understanding the grant making process as a form of market based natural selection - functioning according to the very same laws of economics as other forms of investment - he once asked Hayes, in response to attempts by Jesup to give more structure to the selection process, "Am I to ask these Schools yearly whether they are in debt, \&c, \&c-?"79 His view, detached as it was from the influence of market forces, left Haygood incapable of seeing a role for debt in assessing the feasibility of schools. From his perspective, however, the Slater Fund was successful regardless. Viewing his work as ministry, he found it working positively. "I claim this - Every school I have touched is stronger \& better than it was - in Every one industrial training is begun \& thousands of dollars have been raised by others by the stimulus of what we have done." 80 And, a damning comment on the board's interference, "other schools need \& deserve

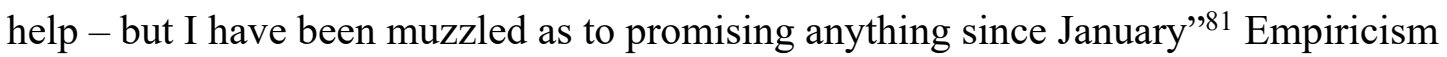
was restraining his calling.

Over time the board would put in place clear expectations for Haygood, to conform to their understanding of how a corporation should function. ${ }^{82}$ But he never quite understood the importance of data and outcomes informing the grant making process. The Fund severing its relationship with one particular school demonstrates the problems inherent in Haygood's approach.

${ }^{79}$ Atticus G. Haygood “Atticus G. Haygood to Rutherford B. Hayes Feb. 12, 1886" Teach the Freeman (Baton Rouge: Louisiana State University Press, 1959), 176.

${ }^{80}$ Ibid.

${ }^{81}$ Ibid.

${ }^{82}$ See the following from Teach the Freeman: The Correspondence of Rutherford B. Hayes and the Slater Fund for Negro Education, 1881-1887 (Baton Rouge: Louisiana State University Press, 1959): “Atticus G. Haygood to Rutherford B. Hayes Jan. 12, 1887," 188; and most notably "Atticus G. Haygood to Rutherford B. Hayes May 20, 1889," Vol. II, 66-69. 
The problem began with recommendations for funding for the 1889-90 academic year. In his annual report that year, Haygood made clear that he doubted the wisdom extending continued financial support to Leland University of New Orleans, Louisiana. The concern with this institution was the industrial education program, which he felt was neither strong nor working toward improvement. ${ }^{83}$ But this is not what was conveyed to the president of the university, Edward Cushing Mitchell. According to Mitchell, the General Agent placed the blame with the Trustees, portraying the decision to discontinue funding as contrary to his recommendation. ${ }^{84}$ When presented with this version of events, rather than deny, Haygood further disassociated himself from the funding recommendations, telling Mitchell, "a year ago I wrote calling attention to the Board's dissatisfaction with results at Leland. But I placed Leland on my list of recommendations...I beg you to see that I am not to blame." ${ }^{, 85}$ But with this rebuke of their program coming as forcefully as a loss of funding from a leading foundation, Mitchell had no choice but to challenge the decision. In a direct and forceful letter to Haygood, he stated, "This is a surprise and a disappointment to me which is really appalling." 86 "What," he demanded, "does it mean? You have given me no hint of dissatisfaction with our work since I came here, and we have been steadily improving our industrial department." ${ }^{87}$ Mitchell then lists some of their improvements, including

${ }^{83}$ Atticus G. Haygood, "Atticus G. Haygood to Finance Committee of the Slater Fund May 11, 1889" Teach the Freeman (Baton Rouge: Louisiana State University Press, 1959),Vol. II, 57.

${ }^{84}$ E.C. Mitchell "E.C. Mitchell to Henry Lyman Morehouse Dec. 19, 1889" Teach the Freeman (Baton Rouge: Louisiana State University Press, 1959), Vol. II, 86.

${ }^{85}$ Ibid.

${ }^{86}$ Ibid., 87.

87 Ibid. 
erecting a building to free up more space for the industrial department, dismissing an incompetent teacher from the agricultural department, and beginning a search for someone to lead their industrial education efforts. "My plans are all upset by this action and I cannot conceive what motive should have induced it." 88

To find some motive, Mitchell prepared a report for the governing board at Leland, demonstrating that they were unfairly denied support. Using the annual report of the Fund as his jumping off point, Mitchell pointed out that the report claims that only eighty of their students were engaged in industrial education, whereas all students were required to participate in some form or fashion. The report makes the claim, again, that their industrial education program was deficient, but that they were completing a new shop, and the carpentry program was poised for quick improvement. One by one, Mitchell ran through the list of other schools supported by the Slater Fund, finding every place in which the Leland University program could claim superiority. They had more students involved in industrial education than Clark University. Meharry Medical College had no students learning industrial methods. Philander Smith College received $\$ 800$ on the basis of their one-line report that "our industrial departments have been very successful this year." 89 Payne Institute admitted that their industrial education program was nothing more than a carpentry class. Furthermore, according to Mitchell, when Haygood made his annual visit of their campus, "he made me a pleasant call and I think took dinner with me, but did not look into our carpenters shop, nor make any inquiries

${ }^{88}$ Ibid.

${ }^{89}$ Ibid., 91. 
about other form of industry." ${ }^{, 90}$ Mitchell sent his report to Haygood, asking for further clarification as to how this decision was made. He received no reply.

But Henry Morehouse, president of the Leland University board, received a curious reply from Haygood. "I have a letter from the President of Leland University inclosing a statement to you. The President appears to be trying to create the impression that the Methodists have been favored above measure." ${ }^{91}$ Nowhere in Mitchell's communication to Haygood, or in his report to his board, does he mention the denomination affiliations of the schools receiving funding. Haygood continued, "The suggestion is indecent. I shall not answer. My reports for years have been published. People can figure on them as they feel inclination." ${ }^{.92} \mathrm{He}$ proceeded to give a false version of events, again shifting blame for the decision on the Board of Trustees, against his recommendation, without addressing what information, data, or outcomes produced their defunding. Haygood ended his remarks abruptly, "I did my best for Leland and was courteous to the President and shielded the failure to do real work there - as well as I could. I shall say no more on this point." ${ }^{\text {93 }}$ It is unclear if Hayes responded to this contentious exchange. But the inclusion of these documents in his papers makes clear he was aware.

Mitchell's rejection of the decision to discontinue funding for Leland University brings to light Haygood's most significant challenge in his approach, and a recurring criticism among many of the Trustees: his assessment of the schools requesting,
90 Ibid.
${ }^{91}$ Ibid., 98.
92 Ibid.
${ }^{93}$ Ibid., 98-99. 
receiving, continuing, and losing funding seemed to be based on nothing in particular. Repeated requests to explore the mission of the Fund in an empirical way fell on deaf ears. Ironically, the Freedmen's Aid and Southern Education Society of the Methodist Church, an organization Haygood regularly spoke on behalf of, and to, encountered the same problem of evaluating outcomes for the school's they financially supported. The secretary of that organization wrote to Hayes, only a few months after the Leland University controversy was set in motion, regarding their solution. "In the grading and unification of our system of schools in the South I have planned a scheme for monthly reports, and I enclose one of the blanks for your inspection." ${ }^{\text {94 }}$ Acknowledging their shared challenges, he conveyed to Hayes, "I think it will interest you and indicating an effort to intelligently and efficiently supervise our great field and to know just what the people are doing toward helping themselves, and just how the money we sent out is expended." ${ }^{95}$ Though perhaps never as directly as was needed, Haygood's denominational brethren produced a tool that would have given his board exactly what they were asking for in terms of information.

After years of simmering conflict over unmet and often unstated expectations, on the heels of the Leland University incident, Haygood decided it was time to exit. A few months later he was elected a bishop of the Methodist church, and though he would see the Fund through the end of the following academic year, it was time for the Agent and the organization to move in a different direction.

${ }^{94}$ J.C. Hartzell, "J.C. Hartzell to Rutherford B. Hayes Oct. 24, 1889” Teach the Freeman (Baton Rouge: Louisiana State University Press, 1959), 80.

${ }^{95}$ Ibid. 
While Haygood never quite seemed to understand what was expected of his position, and certainly never conformed to the corporatist approach desired by the Board of Trustees, the General Agent still played an important role in determining what type of education the Fund would financially support. And the strategy taken by the Board of Trustees and Haygood would have a significant impact on the course of education for African Americans in the South.

Following the first meeting of the board attended by Haygood, he learned they would have $\$ 20,000$ allocated for their initial grants and that information was being widely reported in newspapers. Haygood received requests for funding from schools far and wide. ${ }^{96}$ But before making recommendations, he needed some clarification: "you advise me to prefer these schools to others equally good, as to book teaching, that do not have any handicraft? I so understand the Board," Haygood confirmed, as if to question. ${ }^{97}$ To the question of whether African Americans should receive education in trades or citizenship, the Slater Fund was coming down decisively on the side of technical training. The impact of this decision was immediate.

A favorite school of Hayes' was one founded by a longtime friend, Emily L. Austin's school in Knoxville, Tennessee. Though Hayes endorsed the school, Haygood found it deserved "help on the basis adopted by the Board, \& have promised her what she desired - \$50 a month."98 "That amount," Haygood was certain, "will secure handicraft

${ }^{96}$ Atticus G. Haygood "Atticus G. Haygood to Rutherford B. Hayes Jun 7, 1883" Teach the Freeman (Baton Rouge: Louisiana State University Press, 1959), 92.

${ }^{97}$ Ibid.

${ }^{98}$ Atticus G. Haygood "Atticus G. Haygood to Rutherford B. Hayes Jun 30, 1883” Teach the Freeman (Baton Rouge: Louisiana State University Press, 1959), 93. 
instruction in her school." ${ }^{99}$ This became a pattern for the Slater Fund. Cash strapped schools requested funding from the Slater Fund, and since the Fund was solely interested in 'industrial education,' would do so under the promise to begin offering, or expand, that type of educational program. As Haygood explained to Hayes, quite correctly, "I am more \& more persuaded that by adhering to the policy we have adopted we can get every best school for the colored people at work on the lines so needed by them." ${ }^{100}$ The influence of the Slater Fund on African American education in the South, through this funding policy, became palpable.

In 1884, Haygood reported to Hayes that "the industrial feature is receiving recognition almost Everywhere - the most skeptical [sic] with few exceptions, are convinced."101 Indicative of Haygood's struggles with providing specifics, three years later he offered the first concrete example of their work, and funding, taking root. ${ }^{102} \mathrm{On}$ the strength of their plans for industrial education, Benedict Institute of Charlotte, North Carolina, received a grant of $\$ 800$. That year the lowest amount given was $\$ 400$ to Mount Albion State Normal School, while the largest was $\$ 1,800$ to Shaw University. ${ }^{103}$ Another anecdote from 1887 demonstrates the impact of the Fund's strategy. The president of Central Tennessee College reported that his students were finding that they could, thanks to the training provided by their industrial education program, earn their way through school. He mentioned one student in particular, who was able to build two

${ }^{99}$ Ibid.

${ }^{100}$ Ibid.

${ }^{101}$ Atticus G. Haygood, "Atticus G. Haygood to Rutherford B. Hayes Jun. 18, 1884" Teach the Freeman (Baton Rouge: Louisiana State University Press, 1959), 109. ${ }^{102}$ Ibid.

${ }^{103}$ Trustees of the John F. Slater Fund, Annual Report 1887, 7. 
houses, by himself, in order to pay his way through college. "He began in the College unable to read;" as Haygood relayed the story, "he left able to read well, to write fairly, and to solve problems in common business Arithmetic. He went as far as Fractions." 104 Haygood ends his discussion of this student by conveying that "He is now a good carpenter." ${ }^{105}$ In the same year, Straight University, saw their industrial education program launched. According to Haygood, their president reported on the effort positively, writing, "we mean that our boys and girls shall be able to teach something besides the blue-back Speller." ${ }^{~} 106$ Clearly the Slater perspective was shaping educational outcomes at supported institutions.

In his final year of undivided attention given to his role as General Agent, Haygood provided an overview of the Fund's influence in his annual report to the board. Haygood's inability to take ownership for his short-comings and constant search for applause make his contentions suspect. Yet, if his words are even half accurate, they demonstrate the power of Slater Fund grants. In his estimation, when the board began its work, industrial education programs did not exist in any meaningful way in the South. But, in 1889 , seven years from the start, “...the principle is accepted by all; it has conquered the field; every leading school for colored people in the South seeks means for conducting an industrial department." 107 Most importantly, "it is believed in the South

${ }^{104}$ Atticus G. Haygood, "Atticus G. Haygood to Rutherford B. Hayes Nov. 21, 1887” Teach the Freeman (Baton Rouge: Louisiana State University Press, 1959), 229. ${ }^{105}$ Ibid.

${ }^{106}$ Ibid., 234.

${ }^{107}$ Atticus G. Haygood "Atticus G. Haygood to Finance Committee of the Slater Fund May 11, 1889" Teach the Freeman (Baton Rouge: Louisiana State University Press, 1959), Vol. II, 57. 
that the Slater Fund, more than all other influences, has brought this change." ${ }^{108}$ Never strong in providing measurable data, Haygood does, in this case, provide some strong evidence. He reported to the board that in the academic year 1888-89, more than 6,000 students receiving support for the Fung were engaged in some form of industrial education. ${ }^{109}$ Considering the still developing field of education for African Americans in the South, these are significant figures.

For all of Haygood's shortcomings, his influence, especially when backed by the Slater Fund, was evident. He received near constant requests to come and speak to local populations on the value of industrial education programs. A request from 1886 is a common example. "We are going to have a large educational mass meeting in Montgomery for the purpose of giving the colored people a chance to contribute something toward industrial education in the same way that Northern people do." 110 Specifically, the purpose of the effort was to "...get the colored people to contribute enough to fit up a good blacksmith's shop here." 111 Haygood was assured, that if he would make the trip to speak at the event, "you would have a very large audience and I know great good would be done in the way of stirring our people up to the importance of trying to help themselves." "112 While this request was common, the author was not. Booker T. Washington, in advocating the exact type of educational programming sponsored by the Slater Fund, acknowledged the importance for African Americans in the

108 Ibid.

109 Ibid.

${ }^{110}$ Booker T. Washington, "Booker T. Washington to Atticus G. Haygood” Teach the Freeman (Baton Rouge: Louisiana State University Press, 1959), Vol. I, 179.

111 Ibid.

112 Ibid. 
South in finding success in the free market system. The Slater Fund, in providing funding for these programs, endorsed the road of economic success in an industrial capitalist system as the most necessary training for a disadvantaged class. Accessing the free market system, through training and preparation, was the central motivating factor for both Washington and the Slater Fund. This was, of course, not uniformly accepted - but did become the dominant view of African American education in the South during the period.

The Slater Fund made grants only in support of limited activities. Industrial education programs and requests for unrelated efforts from schools particular adept at industrial education, as well exceptional medical or nursing programs, would all receive consideration. Grants only went to institution - even when funds were sent to a school for student support; that was without regard to who the particular students were or their qualifications, those questions were left to administrators. These funding policies are indicative of the corporate nature of the Fund. Investment was made in institutions not individuals. And though Haygood and Hayes received an almost never ending string of requests for personal support, some not even for anything to do with education, these requests went unfulfilled. There is, however, one notable exception, that in the end proves the rule.

Perhaps speaking rhetorically, since the policy of the Fund was to not provide funding directly to an individual, on November $1^{\text {st }}, 1890$ the former president opened up the flood gate of requests. His remarks, repeatedly printed in newspapers around the country, gave many false hope. "If there is any young colored man in the South whom we 
find to have a talent for art of literature, or any special aptitude for study, we are willing to give him money," Hayes is reported to have said, "from the education funds to send him to Europe or to give him an advanced education, but hitherto their chief and almost only gift has been that of oratory." 113 The first response Hayes received, just four days later, was from W.E.B. DuBois.

DuBois began by conveying his life story to Hayes. Educated at Fisk University DuBois then attended Harvard, where he was a $\mathrm{PhD}$ candidate in political science. "I have so far gained my education by teaching in the South, giving small lectures in the North, working in Hotels, laundries, \&c, and by various scholarships and the charity of friends," and, making him a candidate for support, "I have no money or property myself and am an orphan." "114 Though he was about to finish his $\mathrm{PhD}$, as was tradition among American scholars, his education would only truly be finished after spending time at a German university. For that he required financial support. Hayes also received a letter of endorsement from one of DuBois' professors, Nathaniel Southgate Shaler. ${ }^{115}$ J.L.M. Curry, the new General Agent of the Slater Fund (who also served in the same post for the Peabody Foundation) inquired as to DuBois' fitness with his contacts at Harvard. He explained to Hayes that the "endorsement of the young man is complimentary and persuasive," adding that "his case seems exceptionally meritorious." 116 Regardless, the

113 W.E.B. DuBois, "W.E.B. DuBois to Rutherford B. Hayes Nov. 4, 1890” Teach the Freeman (Baton Rouge: Louisiana State University Press, 1959), Vol. II., 158.

114 Ibid., 160.

115 Nathaniel Southgate Shaler, "Nathaniel Southgate Shaler to Rutherford B. Hayes Mar. 2, 1891" Teach the Freeman (Baton Rouge: Louisiana State University Press, 1959), Vol. II., 189.

116 J.L.M. Curry, "J.L.M. Curry to Rutherford B. Hayes Apr. 8, 1891" Teach the Freeman (Baton Rouge: Louisiana State University Press, 1959), Vol. II., 192. 
policy of the Fund was not to provide direct support to students. DuBois request was denied.

DuBois' penned a thoughtful, yet direct, response. "The outcome of the matter is as I expected it would be," he wrote to Hayes. ${ }^{117}$ "The announcement that any agency of the American people was willing to give a Negro a thoroughly liberal education and that it had been looking in vain for men to educate," DuBois wrote, "was to say the least rather startling." 118 He informed Hayes that he assumed from the outside that the offer was not legitimate, and even considered making a public statement to that fact. Instead, he decided to apply for it himself, to personally bear witness to this bait and switch. And, in his estimation, their actions were inconceivably cruel. "The injury you have unwittingly I trust - done the race I represent and am not ashamed of, is almost irreparable. You went before a number of keenly observant men who looked upon you as an authority in the matter," DuBois chided Hayes, "and told them in substance that the Negroes of the United States either couldn't or wouldn't embrace a most liberal opportunity for advancement." 119 Furthermore, "that statement went all over the country. When now finally you receive three or four applications for the fulfillment of that offer, the offer is suddenly withdrawn," and most disturbingly to DuBois, "while the impression still remains. If the offer was as experiment you ought to have at least one case before withdrawing it." Being even more direct, he offered that Hayes "from the above facts I think you owe an apology to the Negro people. We are ready to furnish competent men

117 W.E.B. DuBois, "W.E.B. DuBois to Rutherford B. Hayes May 25, 1891"

Teach the Freeman (Baton Rouge: Louisiana State University Press, 1959), Vol. II., 203. 118 Ibid.

119 Ibid, 205. 
for every European scholarship furnished us." ${ }^{120}$ In his experience, "I find men willing to helm me through cheap theological schools, I find men willing to help me use my hands before I got my brains in working order, I have found an abundance of good wishes on hand," but the one thing he could not find was "a man willing to help me get a Harvard PhD." ${ }^{121}$ DuBois indictment of Hayes' careless remarks, the funding priorities of the Fund, and the whole system of supporting African American education, was evident. Hayes' response to DuBois has not survived. His words must have been, to some extent, apologetic as the following year, referencing a possible change in policy presented in Hayes' lost words, DuBois applied for support again. ${ }^{122}$ Hayes forwarded DuBois letter to Gilman, and at some point a representative of the board, or perhaps a committee, met with DuBois. The agreement they reached at that meeting was that DuBois would receive a grant of $\$ 300$ and a loan of $\$ 300$ from the Fund. ${ }^{123}$ Though on the low end of the range of grants made, that is still the same level of support received by Paul Quin College of Waco, Texas, Payne Institute of Augusta, Georgia, and Philander Smith College of Little Rock, Arkansas. In those cases, \$600 was awarded to support their industrial education program for an entire year. ${ }^{124}$ For DuBois, $\$ 600$ was the cost of one year of support, for one man, to round out his liberal education and fully enter the scholarly world.

120 Ibid.

121 Ibid.

122 W.E.B. DuBois, "W.E.B. DuBois to Rutherford B. Hayes, Apr. 3, 1892”

Teach the Freeman (Baton Rouge: Louisiana State University Press, 1959), Vol. II., 245.

${ }^{123}$ Daniel Coit Gilman, "Daniel Coit Gilman to W.E.B. DuBois May 23, 1892”

Teach the Freeman (Baton Rouge: Louisiana State University Press, 1959), Vol. II., 252.

${ }^{124}$ Board of Trustees of the John F. Slater Fund, Annual Report 1892, 15. 
This exception suggests the extant of the corporatization of the Slater Fund because DuBois has the distinction of being the only student ever directly supported by the Fund. While the support he received is no secret it is curious where it did not appear. It is not registered in the Fund's annual report. It does not appear in their published accounting records. Hayes, though he would soon after pass away makes no mention of it. Neither does Curry, the new General Agent. Certainly, if they were currently available, there would be an entry for the transaction in their accounting records. But this was never mentioned publicly, anywhere, by the Fund. It was the one clear cut exception to their corporatization of charity. And it would not be repeated.

While the grant to DuBois was not exactly hidden, it is instructive that he was not included in any of the Fund's official reporting. It represented an exception to the corporate culture the Trustees were so focused in creating. A culture of policies and procedures, strategically working toward defined outcomes, and appropriate financial management not just for the Fund's operations but also for those receiving its largess. DuBois may have pulled at their heartstrings, but the funds he received remained an anomaly rather than a break from the Slater Fund's trajectory. It was created by a man committed to the market economy, designed to replicate the functions and methods of for-profit corporations, even going so far as to encourage an educational focus with a clear economic value. Like the Peabody Foundation, the Slater Fund was part and parcel of the market economy. 


\section{Chapter 6}

\section{Young Men's Christian Association}

At the initial meeting to organize the Young Men's Christian Associations of the United States and British Provinces in 1853, the delegates tackled a number of essential questions. In preparation for their deliberations, representatives from local YMCA's provided background to the group concerning the programming and governance of their organizations. The representatives from Boston, Massachusetts and Portland, Maine, informed the gathered men that they served only evangelical Christians, with an executive committee of their board handling day to day operations. ${ }^{1}$ In Louisville, Kentucky, the YMCA utilized lectures by biblical scholars held in venues throughout the city to encourage interest in membership. ${ }^{2}$ Cincinnati, Ohio offered one of the few unique takes, relaying to the delegates that membership was open to all Christians, evangelical or otherwise, and that all decisions were made by the membership at large. ${ }^{3}$ The Washington, DC YMCA required members to be evangelical Christians, as did Chicago, Illinois. ${ }^{4}$ The delegation from Chicago added perhaps the most interesting detail to rather dry proceedings: when looking for a permanent headquarters they intentionally occupied a building called "Harmony Hall," which previously housed a band of spiritual mediums. They were pleased to report that since acquiring the space, "we have not been molested

${ }^{1}$ YMCA Central Committee, Journal of the First Annual Convention of Young Men's Christian Associations, 1854, YMCA Yearbooks, Directories, and Proceedings (Y.USA.56), Kautz Family YMCA Archives, University of Minnesota Libraries, 21-22.

2 Ibid., 23.

${ }^{3}$ Ibid., 27.

${ }^{4}$ Ibid., 21 and 28. 
by a plurality of spirits," noting that instead, “one spirit of 'harmony,' union, and Christian love, has prevailed since." 5 The example of Cincinnati and the tale of Chicago aside, rather than revealing a diversity of approaches, these introductions became repetitive. The next morning instead of continuing the tour or local organizations, the delegates moved on to the business at hand. ${ }^{6}$ But one moment in the proceedings set the stage for what came next. When the Reverend Byron Sunderland rose to address the need for a national association bringing together disparate YMCA's, he asked perhaps the most important question of the gathering: "What is the association but a new product of the Gospel to meet the evident necessity of the times?"7 Regardless of the decisions made that day, in terms of form and function for the national organization, what was certain was that it would reflect the foundational Christianity of the local branches. But the specifics of how that 'product of the Gospel' would function, and what that would mean for the future corporatization of charity, was still to be worked out. That trajectory, however, would be determined over the following three days.

The delegates assembled in Buffalo tackled a number of issues. Representatives from Cincinnati offered a resolution suggesting that all YMCA's engage in organizing at least one Sunday School in their city. This was accepted. ${ }^{8}$ The delegation from Pittsburgh, Pennsylvania offered a resolution encouraging each local branch to organize a monthly prayer meeting, to be held at a time so as to not interfere with regular church services. This was also accepted. ${ }^{9}$ The most contentious resolution put forward, offered
${ }^{5}$ Ibid., 28.
${ }^{6}$ Ibid., 30.
${ }^{7}$ Ibid., 54.
${ }^{8}$ Ibid., 33-38.
${ }^{9}$ Ibid., 44-45. 
by the gentlemen from Cleveland, required limiting membership in local YMCA's to evangelical Christians only. While no definition of 'evangelical Christian' was offered by the assembly, it does appear that generally this was more about what it was not rather than what it was. Catholics, Lutherans, and Anglicans did not count. Baptists, Methodists, and Congregationalists did. A precise definition, however, is as elusive now as it was then. Regardless, after considerable discussion this policy was rejected. Cincinnati, unlike most local organizations, only required a profession of Christianity among its members. ${ }^{10}$ Although not recorded in the minutes, Cincinnati was not alone. Neither the branches in Baltimore, Maryland, nor St. Louis, Missouri, restricted memberships to evangelicals only. ${ }^{11}$ The majority of local organizations, however, held such restrictions. Yet, requiring that degree of conformity among member chapters lacked support. Neither oversight nor command became part of the national organization's charge.

When the idea of organizing a national coordinating body was proposed, the response was immediately positive, but with a caveat. In writing in support of the idea, the YMCA of Washington, DC responded that "while it would oftentimes be judicious to discuss in Convention principles of organization and action, this body shall have no authority or control over the local affairs of any Association." 12 This was seconded by the St. Louis chapter, in a letter to the organizers. From their perspective, "it would not be

${ }^{10}$ Ibid., 27.

${ }^{11}$ See T.M. Cunningham, “Address Before the St. Louis Young Men's Christian Association at its First Public Meeting," Nov. 20, 1853, Young Men's Christian Association, St. Louis Chapter (1853-), Records, Folder 1, Box 1, State Historical Society of Missouri-St. Louis (hereafter cited as SHSM-S), 6, and Jessica I. Elfenbein, The Making of a Modern City: Philanthropy, Civic Culture, and the Baltimore YMCA (Gainesville, FL: University of Florida Press, 2001), 15-16.

${ }^{12}$ YMCA Central Committee, Journal of the First Annual Convention of Young Men's Christian Associations, 11. 
desirable or expedient to confer upon such an alliance, however organized, any authority over the separate associations" ${ }^{13}$ Once the meeting was underway, a formal resolution was put forward which would create "a voluntary confederation, for their mutual encouragement, co-operation, and more extended usefulness." ${ }^{14}$ The organization's duties were to be clearly restricted: "to receive and communicate suggestions as to the best course of action from time to time, it being an option with each Association to adopt or reject them..." ${ }^{15}$ Additionally, the national body encouraged YMCA's to develop in cities where they did not exist, and to facilitate the exchange of information, innovation, and progress among member organizations. ${ }^{16}$ This motion was assigned to a committee for consideration, and when it returned to the overall body for deliberation there was much discussion; though no animus toward the plan was expressed. The motion passed and the Young Men's Christian Associations of the United States and British Provinces was formally created. ${ }^{17}$

With the independence of local YMCA's confirmed - as it remains today - they blazed a unique path. The YMCA was not alone in utilizing independent chapters, the American Red Cross made a similar choice. But there the power of Clara Barton's vision and leadership overcame any real pretense of independence. The United States Sanitation Commission exhibited some independence among local fundraising and distribution efforts. But the administrative prowess and guidance of Frederick Law Olmsted
13 Ibid., 16.
${ }^{14}$ Ibid., 29.
15 Ibid., 30.
${ }^{16}$ Ibid.
17 Ibid., 63. 
overcame most freelancing. The size and scope of the Freedmen's Bureau created challenges to unity of action. The militaristic nature of the organization, however, left no question that Oliver O. Howard was in command. The national YMCA intentionally lacked Bartons, Olmsteds, or Howards. This meant that the direction of the Young Men's Christian Association, incorrectly viewed as a unitary nonprofit corporation, would be mapped by each individual local branch, making decisions that worked best for their unique circumstances. Considering the degree to which the leadership of YMCAs took their cues from their churches, decentralization is not unexpected. Evangelical Christianity, as much as it can be precisely defined across denominations, functioned through affiliated congregations that knew no master. Within a denomination, however, diversity of theology or management tended to be minimal. ${ }^{18}$ YMCA chapters chose similar paths. Rather than building a network of wildly different organizations, with different forms of management, and a diversity of public programming, the chapters followed essentially the same paths. Corporatization was chosen, over and over again, by local agents, boards of directors, and membership bodies, not because it was dictated by a visionary corporate leader, but because corporatization was the most secure path to financial stability and organizational persistence. Additionally, the adoption of a corporate culture signaled the place, or aspirational place, within society of the general membership. This was a group of men who desired a corporatized way of life.

On the face of it, this seems a historical anomaly. Scholars generally paint the thirty-five years following the Civil War as one of conflict between those who owned the

${ }^{18}$ George M. Marsden, Religion and American Culture (Belmont, CA: Wadsworth, 2001), 64. 
means of production and labor. When the middle of the economic hierarchy enters the landscape, it is largely in view of the coming Progressive Era. The middling class, whom held power - economic, political, and social - prior to the war in their individual communities, strike back against impersonal corporate forces to reclaim a place of distinction. But political activism is never universal, and no economic class moves as a monolith. One of the few scholars to examine those in the middle, in particular those who embraced and thrived in the emerging corporate culture, is historian Olivia Zunz.

In his masterly Making America Corporate, 1870-1920, Zunz turns the eye of the scholar on the men who occupied the middle of corporate hierarchies. What he found is instructive for a meaningful understanding of the YMCA: corporatization was created, developed, and implemented much more by those in the middle than from the top. In his examination of local merchants operating as contract sales representatives for the $\mathrm{Du}$ Pont corporation, rather than fighting to maintain independence, most discovered a high level of agency available through corporate integration. By the 1870s these men became a class of 'protoexecutives' rather than resisters of corporate culture. ${ }^{19}$ Zunz, like scholars before and after, found the same changing economic realities that eventually led some to seek major social and economic reforms. But Zunz's middle level manager and local executives, rather than bucking the system, found significance in their role. "Executives needed to bring order to and wring a profit from operations in a variety of settings...each place was subject to the executives' autonomous energies and to newly established bureaucratic procedures of their devising." ${ }^{20}$ Positioned between the highest levels of

${ }^{19}$ Olivier Zunz, Making America Corporate 1870-1920 (Chicago: University of Chicago Press, 1990), 27.

${ }^{20}$ Ibid., 40. 
management above and laborers below, "middle level executives were an intermediary corps" who ordered the work of corporations, and "frequently innovated as much as arbitrated." ${ }^{21}$ According to Zunz, what made America truly corporate, was the influence of middle managers tasked with executing organizational priorities. Likewise, the success of the YMCA - in no small part because of the decentralized nature of the organization required the same agency among local leadership in adopting a corporate culture. One of many examples of this localized effort can be found in the YMCA of St. Louis, Missouri, a chapter's whose history is relatively common.

The history of the YMCA of St. Louis is not particularly unique. In more ways than not it conforms to the basic outlines of how the organization evolved throughout the United States from its inception to the present, which makes it a perfect test case. Its records illustrate that the changes that came to this particular chapter were guided by, but not motivated by, the cultural and religious changes generally associated with the YMCA. Instead, change came to the association for a more basic reason. Like all nonprofit organizations, the YMCA was dependent on its ability to generate revenue. The YMCA in St. Louis failed twice before it succeeded, and when it finally found its footing, it only stabilized because it took a path away from its initial mission of evangelizing toward financial stability and a corporate culture. The first step was expanding its possible membership population by dropping, at least in practice, its earlier restriction of full membership to evangelical Christians; in the process becoming a general rather than

${ }^{21}$ Ibid. 
specifically evangelical Christian organization. The second was identifying, and then broadly implementing a revenue-generating program, a gymnasium. This initial shift is subtle, and in practice, had little impact on programming. The second step produced a more conspicuous affect.

Even in the first year the St. Louis YMCA operated a gym it became evident that that venture would challenge Christianity for the mission of the organization. Like local YMCA's in general, it would take nearly one hundred years before the gym won out; but the tension was evident from the beginning. In reality, the fate of the YMCA's spiritual mission was doomed from the first dumbbell. The St. Louis branch, facing financial demise again in the 1870s, was forced to change or vanish. The Association already proved itself capable of altering its mission in order to maintain its existence. When insolvency faced the St. Louis branch yet again, the only question was in what direction the association would move in order to survive.

A small meeting of twenty-three concerned men in 1853 resulted in the organizing of the local YMCA. The meeting featured an address by local Baptist minister T.M. Cunningham who set the parameters under which the organization would function. In this regard the St. Louis YMCA was almost a carbon copy of the initial Boston branch and successive cities. Cunningham began by expressing the proposed purpose of the St. Louis YMCA: "It is the mental, the social, and the spiritual improvement of young men to keep them or bring them under the restraints of truth and virtue - their preservation on 
the one hand, or their reformation on the other."22 If this organization were successful, the minister claimed that its "influences... shall reclaim [the young men], and, if possible, make them useful members of society, and useful members of the church of God." ${ }^{23}$ If it appears that Cunningham was uncertain that the YMCA could affect the change it sought, it is because he was; St. Louis, like many industrializing cities throughout the nineteenth century was faced with a problem for which history provided no answer.

Eventually the cyclical nature of the American economy would become familiar to industrial workers. At that time though, as cities saw an increase in factory work, farm kids abandoned the volatile agricultural sector for the boom in urban employment. ${ }^{24}$ Unmoored from traditional agrarian life these new migrants struggled to integrate into the community. Cunningham directed his audience to observe the problems the city posed for these young men - the hustle and bustle of St. Louis provided a number of temptations. The largest danger of city life to Cunningham was that a man can feel anonymous, and being unknown by those around him, can slip into even more dangerous forms of amusement: "the lottery, the billiards saloon and card table, the dark sloughs of infatuated dissipation. There is the theatre, with its deluded crowds, its wild dramas, its alluring forms of vice, where thousands rush to lose the realities of life, in grappling with shadows of death." ${ }^{25}$ Cunningham viewed evil around every corner.

22 T.M. Cunningham, “Address Before the St. Louis Young Men’s Christian Association at its First Public Meeting," 6.

${ }^{23}$ Ibid., 7.

${ }^{24}$ Robert H, Wiebe, The Search for Order: 1877-1920 (New York: Hill and Wang, 1967), 12.

25 Ibid., 16. 
This was in many ways a natural concern on behalf of young men faced with the lights of the city for the first time. "A young man comes to our city, and oh, how desolate he feels; how much does he stand in need of the assistance of someone to direct him, to converse with him, to soothe his dropping spirit, tear him away from this garb of loneliness, and make him feel at home." ${ }^{26}$ Generally, a migrant from the countryside came to St. Louis, and, not knowing a soul, expected nothing but frowns and cold shoulders. ${ }^{27}$ The context of the loneliness of the city is where the YMCA served an invaluable role. Instead of remaining anonymous, these young migrants were initiated into the larger community by friendly strangers. By one such stranger they were "taken to a prosperous place of business; by another, put in possession of profitable books; by another introduced into the house of God; by another, brought to this Association."28 With these new found friends and support, the stranger becomes a part of the community, and rather than searching out sinful forms of entertainment takes the moral path. Young men who responded to these acts of kindness by rejecting the Christianly path were, in Cunningham's estimation, doomed to a life of sin regardless. ${ }^{29}$ Searching out these young men in need of guidance would be difficult. Rather than go in search of sorry souls, the YMCA would be a place in which men in need could come in search of assistance.

The best approach to helping these wayward young men, as well as to keep them on their moral path, was through appropriate forms of social interaction and community building. To Cunningham, and the early St. Louis YMCA, this took the form of
${ }^{26}$ Ibid., 9.
27 Ibid.
${ }^{28}$ Ibid.
${ }^{29}$ Ibid, 10. 
intellectual and spiritual growth. ${ }^{30}$ Central to the organization's activities, however, were meetings with a distinct religious purpose. And this is what most excited Cunningham, who proclaimed "oh how grand is this, for the young men to meet together, to read and study the Word of God! - to take it as their guide, as the man of their counsel, as a light to their feet, and a lamp to their path." ${ }^{31}$ This common faith, in Cunningham's estimation, would be central to building a community as the men gathered for moral and intellectual growth. ${ }^{32}$ While the idea that these men would assemble under the banner of one faith permeated the rhetoric of the organization's founding, this was an idea that could be problematic.

When the YMCA was initially founded in 1844 in England, George Williams, who developed the idea, was faced with a number of decisions regarding the role the organization should play in the conflict between protestant denominations. If the YMCA aligned with a particular denomination that would limit the number of possible members since the idea was to create a large community of men, that path would not do. Likewise, there were some who thought that the YMCA should serve as the spiritual home for its members, becoming a church itself. But to Williams the fractured state of protestant theology, and the fact that young men seemed to not find much comfort in ministerial pontificating on such subjects, led him to focus the organization's energies elsewhere. The YMCA would be an umbrella organization for all men who belonged to an evangelical church. Thus, the originating chapter, though committed to an evangelical approach to Christianity, deemphasized theology and ritual, and created an environment
${ }^{30}$ Ibid, 7.
${ }^{31}$ Ibid.
${ }^{32}$ Ibid. 
in which no denomination dominated. This policy stand became central to the development of the YMCA in the United Kingdom, as well as the United States. ${ }^{33}$

The St. Louis YMCA, in its inaugural address, adopted this philosophy as well: "If the youth of our city are to be saved, if the temptations of the city are to be destroyed, this work will not be done by one denomination in particular, but by the co-operating tendencies of all Christian denominations. ${ }^{34}$ It was also clear that Cunningham, and the local chapter, felt that not all Christians were created equal in this effort. The members, according to the minister, were to be "....professors of religion. For membership in some Evangelical church is an express qualification for active membership in this society." 35 Those men who did not belong to an evangelical church would not be banned from the association completely, just voting and office holding. ${ }^{36}$ Clearly not all Christians would quite be on equal footing in this cause. According to the organization's constitution, in order to be classified as an active member a man had to belong to an evangelical church, be under forty years of age, and pay a yearly membership due of one dollar. Associate members also had to pay an annual membership fee of one dollar and be of “...good moral character..." ${ }^{" 37}$ Men who wanted to join but were no longer considered young (over forty) could also join the organization, but were listed as honorary members; the distinction between active and associate members therefore had nothing to do with age.

${ }^{33}$ Mayer N. Zald, Organizational Change: The Political Economy of the YMCA, (Chicago: University of Chicago Press, 1970), 25-26.

${ }^{34}$ Cunningham, 14.

${ }^{35}$ Ibid., 12.

${ }^{36} \mathrm{Ibid}, 12-13$.

37 "First Annual Report of the Saint Louis Young Men's Christian Association," 1854,6 . 
The only codified difference between active and associate members was membership in an evangelical church.

But most associate members listed affiliation with a church. And the requirement for membership in an evangelical church was clearly applied loosely, as many active members belonged to non-evangelical denominations. Without any distinction between active and associate members who belonged to the same denomination, and attended the same church, it must be assumed that membership status was based more on standing within the organization than church affiliation. By 1856 there was still a distinction between active and associate members, and the requirements for association members had not changed in any substantive way. Active members, however, were no longer required to be evangelical Christians, instead, "active members shall be such as, on account of their zeal in the affairs of the Association." ${ }^{38}$ A member could be elected to the higher membership class. With commitment to the culture of the YMCA replacing evangelical Christianity as the common denominator among full members, the St. Louis chapter was ripe for change.

It has been noted by scholars that the YMCA's early membership was from the rising class of managers created by the industrial revolution - Zunz's middle managers. ${ }^{39}$ That appears to be the case with the St. Louis YMCA as well. Yet, unlike the Boston YMCA, which spawned the growth of the organization in the United States, the St. Louis chapter shed its evangelical identity almost immediately. Lip service would continue to

38 "Third Annual Report of the Saint Louis Young Men's Christian Association," 1856, Young Men's Christian Association, St. Louis Chapter (1853-), Records, Folder 7, Box 1, SHSM-S, 6.

$$
39 \text { Zunz, } 27 .
$$


be paid to the requirement that full members be evangelical Christians, however, it is clear that the organization was pushing away from its original mission.

What motivated the move away from being an evangelical organization was an issue that always plagues nonprofit organizations: revenue. In 1853 the St. Louis YMCA registered 161 yearly members (at $\$ 1$ per member), 7 life members (who made a onetime payment of $\$ 20$ each), received $\$ 96$ in donations, and collected $\$ 717.45$ in tickets to their lectures. This provided the organization with $\$ 1,114.45$ in revenue for its first year of existence. That first year also brought a number of expenses - \$279.16 for carpets, $\$ 106.44$ for chairs and tables, $\$ 9.50$ for a stove, $\$ 182$ in printing, $\$ 6.00$ for advertising, $\$ 250$ to rent a hall for lectures, and a number of other payables - resulting in $\$ 998.51$ in total expenditures. ${ }^{40}$ This left a balance for the year of $\$ 115.94$, or slightly more than $10 \%$ of their operating budget. Things did not go as well in 1856 .

The organization went through significant changes in leadership, establishing an executive board to replace what had been a single incompetent executive in charge. The St. Louis YMCA also received a charter from the state of Missouri, and the pre-charter organization transferred its property to the new organization. This change in legal standing presented a unique problem as previous members had "misapprehension as to their separate character, many members of the former have not yet applied to be formally enrolled in the latter; whence results an apparent diminution in the present enrolled $1854,12$.

40 "First Annual Report of the Saint Louis Young Men's Christian Association," 
membership, to between 70 and $80 .{ }^{\prime 41}$ Those leery of corporatization, made all the more concrete by charter as a corporation, and the accompanying culture, simply left.

Another problem the organization faced was its lecture program. The first half of the year, with talks such as "The Character and Religious System of Mohammed," "Modern Geology: Its Facts and its Assumptions," and "Modern Spiritualism" did well financially. The second half of the year, with features such as "The Model Husband," "The Model Wife," "The Rise and Fall of the Bourbon Dynasty in France," and "The Fathers of the Church" did not meet financial expectations. All of the lecturers were wellknown scholars on the subjects brought to St. Louis and compensated; driving up the cost of these programs. Donations were secured to alleviate the financial burden on the organization, but, what had been expected to produce a financial windfall instead barely broke even..$^{42}$ At the end of year, the organization reported a small surplus of cash on hand. ${ }^{43}$ This left the Association's financial position significantly diminished from its founding.

It is unclear whether finances from organizational challenges or complications from the coming of the Civil War doomed the first attempt at a St. Louis YMCA. But, this local branch reflects the history of the YMCA nationwide; most chapters of the organization found it difficult to survive the strain of the conflict. The St. Louis branch attempted to rebuild shortly after the conflict subsided, but this effort would also be a misfire. Lasting only a handful of years, the second attempt at a local YMCA failed -

\footnotetext{
41 "Third Annual Report of the St. Louis Young Men's Christian Association," $1856,9$.

${ }^{42}$ Ibid., 10.

${ }^{43}$ Ibid., 11.
} 
even failing to have its years of existence recorded. In 1875, however, the organization finally found its legs in the community, and what today is the St. Louis YMCA was chartered. $^{44}$

The third incarnation of the Association was very much crafted on top of the foundation constructed by the first. The stated purpose of the third St. Louis YMCA was "the development of Christian character and activity in its members; the promotion of Evangelical religion; the cultivation of Christian sympathy and the improvement of the spiritual, intellectual and social condition of young men." ${ }^{45}$ Echoing the comments made by Cunningham at the founding meeting in 1853, the Association in the 1870s described the duties of members as to "seek out young men, residents or strangers in St. Louis or its vicinity; and endeavor to bring them under moral and religious influences by aiding them in the selection of suitable employment and boarding places."46 The Association's bylaws detailed further duties for members, requiring them to "secure their attendance at some place of worship on Sabbath, and in every means in their power surrounding them with Christian influences." 47

Interestingly, in the Association's first annual report the only reference to evangelicalism was found in the statement of the organization's purpose (quoted above). This third life of the Association, in the interest of meeting organizational goals, appears to have shed its evangelicalism both in function, and almost completely in rhetoric -

44 “St. Louis Young Men's Christian Association," ud. c.1920s, Young Men's Christian Association, St. Louis Chapter (1853-), Records, Folder 33, Box 1, SHSM-S, 12.

45 "First Annual Report of the St. Louis Young Men's Christian Association," 1877, 4.

${ }^{46}$ Ibid.

${ }^{47}$ Ibid. 
repeating the decisions made by the first St. Louis YMCA. In addressing the early challenge that faced the YMCA, of whether to support existing denominations or form its own church, the St. Louis chapter's president, H.C. Wright, commented that "in our work as an Association, we have always studiously avoided any assumption of equality with the Church, but have sought to co-operate with all Christian churches and to act as feeders to them." 48 This statement of ecumenicalism complicated the organization's stated intent - to create an umbrella auxiliary organization for men to work in conjunction with evangelical denominations. It does, on the other hand, represent what was happening in reality within the organization. Paying little attention to denominational affiliation would be key to organizational growth.

Equally important to the growth and success of the association were the programs offered to members. Much like the initial YMCA in St. Louis (and, we can assume, the second), the organization founded in the 1870s offered lectures concerning religion and science, as well as a number of concerts, each of which resulted in a financial gain for the association. ${ }^{49}$ It also maintained a reading room, similar to the initial association, which featured a number of periodicals and over 300 books in circulation. ${ }^{50}$

Unlike the initial organization, the third incarnation of the association expanded the programs offered to members, and potential members in ways that would re-cast the mission. First, the organization began to offer religious services in the places in which fallen migrants to the city could be found. This included "the City Hospital, Work House,

${ }^{48}$ H.C. Wright, "President's Message," printed in "First Annual Report of the St. Louis Young Men's Christian Association," 1877, Young Men's Christian Association, St. Louis Chapter (1853-), Records, Folder 8, Box 1, SHSM-S, 7.

${ }^{49}$ Ibid., 11.

50 Ibid., 13. 
Marine Hospital, News Boys Home, Jail and Insane Asylum."51 They even held services in private homes in the working class sections of the city, noting that "many have been found willing and anxious to attend. ${ }^{, 52}$ One of the problems Wright set as a priority for the St. Louis YMCA was that "strangers visiting our city, often asked the question, 'where are the rooms of your Young Men's Christian Association?' and the Christian citizen was compelled to answer with mortification that...there was no such Association." ${ }^{53}$ Although it would not be until the turn of the century that dormitories and 'staying at the YMCA' became a cultural phenomenon, by the 1870 s it was common for YMCA's in large cities to offer meager room and boarding for newly migrated men. The St. Louis chapter took steps to match other cities, constructing the "Industrial Friendly Inn," which featured a restaurant, chapel, rooms for rent for new migrants, a reading room, bathroom, and a laundry. ${ }^{54}$ Young men could stay at the inn for a small fee - as it was constructed with donations this became a revenue generating enterprise for the association - while the destitute who "were deemed worthy...were furnished gratis." ${ }^{55}$ As could be expected, religious services were regularly offered at the chapel. In the first year of its operation the Inn served more than 14,000 meals, lodged more than 3,000 men, and found employment for around $150 .{ }^{56}$

In the 1870 s the much-expanded St. Louis YMCA raised more money than its antebellum predecessor. In 1877 the local chapter reported an income of $\$ 3,148$. It also
${ }^{51}$ Ibid., 10.
52 Ibid.
${ }^{53}$ Ibid., 6.
${ }^{54}$ Ibid., 12.
55 Ibid.
${ }^{56}$ Ibid. 
expended more, reporting $\$ 3,060$ in outlays. This left the organization with $\$ 87$ in cash on hand. As much as the Association tried to place their finances in the best light, financial stability was still elusive. ${ }^{57}$

By 1888 the St. Louis chapter of the YMCA expanded to four branches - the Union Depot Railroad Branch, the Down Town [sic] Branch (which also housed the organization's headquarters), the 'German' Branch, and the 'Colored' Branch. ${ }^{58}$ Each of these locations offered similar services, though they remained small in scope, especially in comparison to what occurred at the 'Down Town' Branch. It continued to offer a reading room, with holdings expanded to 1,700 volumes. At least in rhetoric, the association's focus was still its Christian mission: "Larger growth has been seen in our religious works the past year than in any other of our departments; more meetings have been held, with larger attendance and better results." 59 This was a good thing as "the chief aim and purpose of the Association, to which all other agencies are subordinated, is the salvation of young men." ${ }^{\circ 0}$ The religious program included ten services a week, Bible classes on Sunday afternoons, prayer meetings held Saturday's, and evening prayers each night. ${ }^{61}$

By 1888 the association no longer offered accommodations for newly arrived young men to St. Louis. Instead they added a battery of educational opportunities for its

\footnotetext{
$1877,11$.

57 "First Annual Report of the St. Louis Young Men's Christian Association," 58 “ $12^{\text {th }}$ Annual Report: St. Louis Young Men's Christian Association," 1888, Young Men's Christian Association, St. Louis Chapter (1853-), Records, Folder 8, Box 1, SHSM-S, 14.

${ }^{59}$ Ibid., 11.

${ }^{60}$ Ibid., 11-13

${ }^{61}$ Ibid., 14.
} 
members, including "classes in penmanship, book-keeping, stenography, German, Spanish, elocution, vocal and orchestral music and mechanical drawing." ${ }^{\prime 2}$ They created a literary society, which met every two weeks. Unlike previous years, however, the organization only offered two public lectures. Expecting possible criticism of this decline in lectures, the association offered a preemptive defense: "That more had not been done in this direction is due to the fact that we have no hall suitable for the purpose. ${ }^{\prime 63}$ Unless, of course, they closed the gymnasium for the event.

By 1888 the gymnasium became the primary feature of the association's programming. Of the 50,654 visits to the YMCA that year, 20,863 of those were visits to the gym. Throughout the year the gymnasium averaged sixty-seven visits a day, offered 177 classes, attended by 3,814 young men. The gymnasium also conducted more than 120 physicals, and provided the facilities for more than 13,000 baths. "But these figures do not begin to express all the good that has come of our gymnasium. Aside from affording a place of innocent recreation, many found it...our aim to make it a promoter of health." ${ }^{64}$ The addition of a gymnasium offered two benefits to the members. On one hand, there were clear health benefits, and many of the new members were referred by doctors concerned with their vitality. Then there were the spiritual benefits that others had "...found [in] its severe discipline a safeguard against certain temptations which have beset young men." 65
62 Ibid., 11.
${ }^{63}$ Ibid., 10.
${ }^{64}$ Ibid.
${ }^{65}$ Ibid. 
The organization's annual report for 1888 offers some clues as to the shift in focus. The association's discussion of the addition of the gymnasium first addressed the health benefits and then the spiritual. In terms of the overall program offerings of the organization, the success of the gym was presented to the reader first. The successes within the religious program, as significant as they were claimed to be, were discussed last. The rise of the gymnasium had clearly eclipsed the public lectures, and as much as they attempted to pretend that it was not the case, it would soon surpass the organization's religious function. In the gymnasium, the St. Louis YMCA secured long sought financial stability. Where rhetoric points to this reality, so did the organization's finances.

In 1888 the organization's income, buoyed by the addition of the gymnasium, rose to $\$ 12,647$. Donations to the capital campaign that would grow the branches and facilities of the organization resulted in more than $\$ 7,000$ while membership fees ballooned to almost $\$ 4,000$ a year. The organization also collected fees for use of the bowling alley $(\$ 175)$, rental of lockers $(\$ 281)$, and selling manuals for gym users $(\$ 8.25)$. Expenditures also grew, nearly matching the organization's income. At the end of the year, with the recent addition of the gymnasium still weighing on the budget, $\$ 52$ remained, but the organization reported having no remaining debt. ${ }^{66}$ In 1888 it is conceivable that the capital campaigns that built the association's infrastructure were driven by interest in religious programing. But what maintained the operational budget of

66 Ibid., 17. 
the organization were membership dues, which were clearly dependent on access to the gymnasium for stability and growth. ${ }^{67}$

The financial records for the years immediately following 1888 bear witness to this. In 1889 the St. Louis YMCA's income rose to $\$ 13,459$, with a growth of membership revenue to $\$ 4,150$. Expenditures also rose, leaving the organization with a grand total of $\$ 1.07$ cash on hand. ${ }^{68}$ The year 1890 brought growth across the board, with $\$ 15,498$ in revenue, and more than $300 \%$ growth in end of year cash on hand, for a remaining balance of $\$ 3.41 .^{69}$ In 1890 the Association ended a capital campaign; the overall revenue for the organization fell to $\$ 13,671$, however, the end of year cash on hand balance grew to $\$ 48.63 .^{70}$ Although that is a remaining balance from the year small enough to give the most courageous of organizational leaders pause, the next year would see the investments of the previous years pay-off.

Unfortunately 1892 is the last year in the $19^{\text {th }}$ century for which an annual report was kept in the organization's archives. Yet, that report is instructive as to the state of the Association going into the $20^{\text {th }}$ century. The outlines of the organization remained much the same from previous years. The fundraising of years past were finally evident in the full operation of two new branches - a railroad branch in East St. Louis and new

67 Ibid.

68 “ $13^{\text {th }}$ Annual Report: St. Louis Young Men's Christian Association," 1889, Men's Christian Association, St. Louis Chapter (1853-), Records, Folder 9, Box 1, SHSM-S, 17.

69 “ $14^{\text {th }}$ Annual Report: St. Louis Young Men's Christian Association," 1890, Young Men's Christian Association, St. Louis Chapter (1853-), Records, Folder 9, Box 1, SHSM-S, 14

70 “ $15^{\text {th }}$ Annual Report: St. Louis Young Men's Christian Association,” 1891, Young Men's Christian Association, St. Louis Chapter (1853-), Records, Folder 9, Box 1, SHSM-S, 13. 
'German' branch on the south side of the city. ${ }^{71}$ The organization was still claiming to be "kept strictly within the hands of Evangelical Christians" though nothing in its constitution or organizational structure enforced such rhetoric since the decade before the Civil War. ${ }^{72}$ The association still maintained a reading room and educational classes, it beefed up its lecture series (thanks to new facilities there was not as much jostling for space at the central branch), and a number of religious services, Bible study, and discussion groups were still maintained. As could be imagined with the expansion in both locations and facilities, the number of visits to the YMCA expanded exponentially to $202,673 .^{73}$

The breakdown of that figure provides insight into the organization's focus. A little more than 41,000 young men attended religious services at a YMCA in St. Louis that year. Yet, more than 45,000 visited the gymnasium. Add to that number the 13,594 who attended fitness classes and it becomes clear that by the early 1890 s the body was outpacing the spirit in YMCA programming. ${ }^{74}$

During this period the St. Louis YMCA was not merely responding to a wider cultural phenomena in which the body and the spirit were becoming more entwined for evangelical Christians. Rather, it was experiencing Mission Creep, when an organization drifts away from its initial mission to take advantage of other revenue generating opportunities. While the coupling of Christianity with masculinity during the period,

71 "Sixteenth Annual Report of the St. Louis Young Men's Christian Association," 1892, Young Men's Christian Association, St. Louis Chapter (1853-), Records, Folder 9, Box 1, SHSM-S, 6.

${ }^{72}$ Ibid., 8.

${ }^{73}$ Ibid., 8-9.

${ }^{74}$ Ibid., 9. 
within a culture increasingly concerned with health and appearance occurred, these merely illuminated the path the YMCA fully crept away from its initial purpose. The cause, however, was debt. Each of the organization's annual reports examined for this study either speak of having avoided debt in that year - giving the impression that that was an uncommon end of year position - or gave a total for their debt. Even when the end of year brought a financial situation in the black, the remaining cash on hand was rarely above a pittance. In 1892 , the St. Louis YMCA reported that it was $\$ 3,800$ in the red ${ }^{75}$ Being in debt was not new to the Association, but such a significant debt was new. The financial situation in 1892, however, was different from other years.

The previous year, for which the annual report was detailing, witnessed a second German branch move from one location to a larger one. The new location, a mansion on Carondelet Street, was offered to the organization at a significant discount. Even with this new facility it was determined that the branch would require an expansion to house an appropriate sized gymnasium. As such, $\$ 16,000$ was put toward the purchase of the mansion and $\$ 6,000$ to add the gym. This left the organization with more than $\$ 3,800$ in debt. ${ }^{76}$ The fact that the Association felt that expanding the new site was necessary enough to assume a debt equivalent to $22 \%$ of its total operating budget is instructive. The organization's leadership gambled that it could maintain its existing financial commitments while assuming this new debt. They did this because they assumed it would not be a gamble at all. In that year the organization closed their books with $\$ 653$ on hand after making required payments to service the debt. More importantly, the St. Louis

\footnotetext{
75 Ibid., 10.

${ }^{76}$ Ibid.
} 
YMCA learned that the gymnasium drove its financial stability. Undertaking debt to support fitness facilities would end up paying off. This is the moment when the gymnasium overtook Christianity as the focus of the St. Louis YMCA in practice and programming.

But the experience of this local chapter is merely one window onto a changing landscape within the YMCA nationally. Moving from an evangelical reading room to a generally Christian gymnasium was just the first of many steps that resulted in the Young Men's Christian Association becoming the all-inclusive ' $\mathrm{Y}$ ' of today. But a singular focus on one specific place, as much as its history conforms to the general outlines, still does not make completely clear what was happening. Scholars of 'Christian Masculinity' would look on the St. Louis experience and assume that it proved their larger point. But the inclusion of gymnasiums was more than just the programming and facilities made possible. They became a way of generating revenue - the cash needed to prove that the YMCA was a stable organization, operated in a businesslike function, instilling a corporate culture, both in its management and membership. The adoption of the gymnasium offered a path to organizational legitimacy that was not be found in reading rooms, lecture series, or evangelical Christianity alone. By expanding the field of view from the local to a more widely national scope, it is clear that the St. Louis example was quite common, middling even.

While each local organization remained independent, that did not prevent the national association from guiding the way. For the entirety of the period examined, the national confederation of YMCA's produced a massive body of instructive for local 
branches. The breadth of these publications is large, covering topics from organizing prayer weeks and daily prayer topics, to how to manage their gymnasiums. But nothing speaks to the corporatist nature of the YMCA more than those works addressing the business nature of local organizations.

One of the earliest of these efforts in Erksine Uhl's treatise, a title illustrative of the consultative rather than supervisory nature of the relationship between national and local associations, Suggestions Concerning the Financial Management of a Young Men's Christian Association. ${ }^{77}$ Published in 1878 , Uhl offered a blueprint for how organizations could find the proper financial footing. First, they must secure a building. By acquiring a permanent home, organizations found a somewhat dependable source of income in rents for the building during the periods in which it was not used by the membership. If done correctly - with a unified membership advocating and supporting the campaign; marketing the new building to the community by highlighting the wide communal benefits of similar facilities in other cities; and identifying revenue generating activities (such as a concert series) and investing the profit from those efforts with a view to longterm rather than short-term outcomes - then a building should be secured in short order. Uhl estimated five years in most cases. ${ }^{78}$ Establishing a permanent home, however, was among the most perilous actions an organization could undertake.

${ }^{77}$ Erskine Uhl, Suggestions Concerning the Financial Management of a Young Men's Christian Association (New York: The Executive Committee of the Young Men's Christian Associations of the United States and British Provinces, 1878). Suggestions Concerning the Financial Management of a Young Men's Christian Association 1878, Miscellaneous Research, Planning and Development Records (Y.USA.34), Kautz Family YMCA Archives, University of Minnesota Libraries.

78 Ibid., 3-5. 
Uhl felt that local chapters obsession with a building led away from the mission of the organization. What would result in a successful building campaign were the same things that made the chapter successful in the first place: "the most important element in getting a building is hard, earnest, successful work in every department of the Association."79 The danger was the short cut to obtaining a headquarters; rather than doing the work and building their fundraising capacity, Uhl worried that organizations would instead opt to take on debt. The actual debt was not the problem, but rather the interest that came in tow. For chapters in which the building would guarantee income through rentals, it was possible that interest made sense, but generally Uhl held that the expense of interest would outpace other income, resulting in financial ruin. ${ }^{80}$

As much as a building was an important financial foundation, the second building block - a stable annual income - was important regardless of where a chapter was in its lifecycle. The key, according Uhl, was planning for the fiscal year well in advance by pulling together a robust proposal with multiple revenue streams, and executing that scheme as designed. For most chapters this meant implementing compelling programming that would raise immediate revenue, increase the impact of the association throughout the community, and develop future members and donors. Often this was done in the form of lectures. But what Uhl termed as 'entertainment' also presented pitfalls. Too often organizations would plan programming without considering the costs or possible revenues, and even worse, losing track of their mission in the process. If the program for the year was not inherently Christian in its nature, or fit the mission to

\footnotetext{
${ }^{79}$ Ibid., 5.

${ }^{80}$ Ibid., 5-7.
} 
"instruct and elevate," or took into account the scheduling needs of their memberships, then positive effort would instead become negative. ${ }^{81}$ It was, the author declared, better to lose money on a lecture than to garner revenue and lose prestige or members. Uhl acknowledged that the associations operated within a free market of entertainment and growth opportunities within cities, but that they must "keep our work before the people." 82 While "thorough and judicious advertising is as necessary here as in the conduct of any business operation" - clearly the YMCA was at its heart a business operations in the author's and the national associations view - "but we must weary by overmuch clamor or disgust by extravagant statement." ${ }^{83}$ While taking advantage of modern marketing methods, local chapters were forced to walk a tightrope between competition in the market of ideas and its organizational missions.

While much of Uhl's suggestions and admonitions feel more theoretical, he also offered specific methods to increasing revenue. Interestingly, the plan he presents should be familiar to modern nonprofit professionals, and echoes fundraising basics still utilized. He informs readers to always retain up to date lists of members names and addresses, as well as those who have attended events or shown interest in chapter programming, and especially to identify and keep updated lists of prospective high dollar donors. Those inhabiting the lists should be kept apprised of activities through regular contact via a newsletter and programming bulletins, capped by a printed annual report. The goal of all of which was to transition members, supporters, and potential supporters into becoming annual subscribers. Uhl even provided a process for executing a 'systematic canvas in

\footnotetext{
${ }^{81}$ Ibid., 8-10.

${ }^{82}$ Ibid., 11.

${ }^{83}$ Ibid., 11-12.
} 
support of gaining annual subscribers. ${ }^{84}$ A committee should be assembled with each member assigned "those he can most easily approach." ${ }^{85}$ Men assigned this task “...should thoroughly understand the work of the Association and the use made of its funds, and should be able to present these facts clearly and to meet any objections that may be raised." ${ }^{86}$ This task was difficult, and "to deal well with the peculiarities of the individuals he encounters he must have abundant tact and skill. In some cases he may succeed better if accompanied by one or two well-chose person [sic]." ${ }^{97}$ Good advice for raising money then as now.

The author knew that his guide to financial stability worked as he witnessed his system in action; his home YMCA in Syracuse, New York used the plan throughout the 1870 s to great success. As a method of applying business principles to generating revenue for a nonprofit organization it was solid. Yet, Uhl worried about the spirit in which his system would be implemented. "It scarcely need be said" though he made sure to write it, "that such efforts are unworthy unless actuated by higher motives than the mere pecuniary welfare of the society, still this is one of the important ends incidentally furthered by them." 88 Considering the debate happening within many local chapters concerning the place of the gym in their program during this era, we might expect to find this issue addressed by Uhl. Instead, he ends his pamphlet by encouraging chapters to pay equal care to their reading room and their gymnasium so as to make them conductors rather than detractors of the spiritual mission, both being important to the cashflow of the
${ }^{84}$ Ibid., 13-15.
${ }^{85}$ Ibid., 14.
${ }^{86}$ Ibid.
${ }^{87}$ Ibid.
${ }^{88}$ Ibid., 15. 
organization and a building block of the mission. He concludes, however, by reminding his readers that the organization's finances required the same management "as a sharp business man manages his business. ${ }^{89}$ His ultimate point is clear; to serve its mission, local YMCAs had to operate as businesses in service to the purpose, rather than in service to profit alone. But they still required a profit. And profits were most readily attained through business management systems and strategies reflective of a corporate culture.

These were reoccurring themes in the literature of the YMCA in this period. An address given by a prominent member of the Pittsburgh association to the national convention in 1891 was reproduced as a pamphlet for wider distribution. In that tract, W.K. Jennings, a lawyer by trade, provided broad guidelines for how chapters should organize their business activities, claiming that conducting "their operations upon sound business principles" was key to the organization's past and continued success..$^{90}$ Considering that it was an organization largely of young men, Jennings found it remarkable that they were able to temper their enthusiasms and lack of experience to enjoy organizational growth and stability. He attributed this to six distinct maxims of management, which he advised chapters to implement or continue to follow. First, experienced businessmen, regardless of age, should be invited to join the local board. But it could not be just anyone involved in the world of commerce. Those entrusted with the direction of a local chapter had to be successful businessmen as "the qualities which make a man successful in the mercantile world, when sanctified and consecrated to the

${ }^{89}$ Ibid.

${ }^{90}$ W.K. Jennings, Business Management in Our Associations. 1891, 1. YMCA Business Administration Commission Reports, Miscellaneous YMCA Research, Planning, and Development Records (Y.USA.34), Kautz Family YMCA Archives, University of Minnesota Libraries. 
Lord's service, enable him to guide wisely and well the affair of an Association." ${ }^{91}$ While not losing track of the spiritual mission of the organization, clearly the YMCA was at least equal part service and business in the eyes of Jennings.

His second maxim, that associations should be guided by an annual budget, with fundraising goals set to meet those needs, came with a warning to execute quickly. If fundraising fell short of budget goals, by initiating the campaign early in the fiscal year, leadership still had options for cost cutting. This was necessary to meet the third maxim, that debt should be avoided at all cost, and when incurred, paid quickly. Jennings asserts, with a degree of tongue-in-check, "the fact that religious societies are proverbially dilatory in paying their debts is so well known that capitalists are always loath to invest in their securities." 92 Jennings offered to his audience that "one would think that those who profess to be governed by Christian principles, and to maintain a high moral standard in all their dealings, would be the very persons who could be trusted," but instead, he found they "seem to merge their individuality into the corporate body, letting their consciences go with other things, so that it has become a proverb that corporations are conscienceless." 93 The YMCA, in order to sustain itself, had to be a corporation, but Jennings warned they must place their mission at the center of those dealings, and be a uniquely moral corporation.

In the fourth point, the author encouraged associations to keep the leading men of industry and commerce within their city informed of the activities of the chapter. Even if these men were not interested in membership, or participating in programming, their

\footnotetext{
${ }^{91}$ Ibid., 3.

92 Ibid., 4.

${ }^{93}$ Ibid.
} 
moral and financial support were valuable currency. Local support, even among nonmembers, would beget investment, even among non-members. This is where Jennings found the addition of gymnasiums to local buildings wise, not just as a source of revenue, but a point of interest among the uncommitted. "But that large class of men who think there is more Gospel in a loaf of bread than in a tract, may be appealed to by presenting the excellent effects of the gymnasium, not only upon the physical conditions of young men, but in...keeping them from temptation." 94 The gym was designed to attract support from the churched and unchurched alike.

Jennings final two guidelines are of particular note because they ask associations to not just operate like corporations, as found in his first four, but to replicate corporate hierarchies. In his fifth point, he makes explicit that board members should understand the history and aims of the association, but as he elaborates his purpose is different from what it appears at first. Rather, he is calling for board members to be actively involved in the communication of the organization, not just locally but throughout the state, within the national and even international confederations. "Considering all the International, State, and District conventions constantly held, and the very instructive, interesting, and statistical reports issued, there is very little excuse for ignorance." 95 Yet, Jennings found directors "who go on making costly blunders that they might have avoided if they had only availed themselves of the experience of other Association men." ${ }^{\text {" }}$ It was the duty of each board member to be fully engaged in the consumption of information circulated throughout the corporatist structure of the organization. But to truly ensure proper

94 Ibid., 4-5.

95 Ibid., 5.

${ }^{96}$ Ibid. 
management, and Jennings' final maxim, local chapters - even those serving small towns with few resources - had to utilize the services of a chief executive officer. Someone has to man the helm day to day and ensure that the chapter was being managed properly. By 1891, the benefits of a chief executive in terms of the application of business principles was widely recognized to the point, Jennings informs us, that chartering new locals was discouraged if their plan did not involve beginning with a General Secretary in place. ${ }^{97}$ Saving souls was still the mission of the YMCA, but as Jennings himself points out, "spiritual and temporal affairs are so intimately allied that it is difficult to determine where one ends and the other begins. $" 98$

Uhl and Jennings were not lone voices in elevating of business practices and corporate culture with the spiritual. In the national confederation's catalog of publications - available for purchase by local chapters and members concerned with association improvement - a number of resources addressing financial issues appear in the advertisement. ${ }^{99}$ On the very first page of publications, listed alongside the two most prominent YMCA periodicals, The Intercollegian and The Foreign Mail, sat an offer of “Association Financial and Record Blank Books," which were "in use by the leading associations throughout the country." 100 Members who perused the catalog in 1901 would find much guidance on the business affairs of their chapter, such as Finances of Student

${ }^{97}$ Ibid., 5-6.

${ }^{98}$ Ibid., 2.

${ }^{99}$ Publications of the International Committee of Young Men's Christian Association (New York: International Committee of the Young Men's Christian Association, 1901). Catalogs, 1885-1979, Miscellaneous YMCA Research, Planning, and Development Records (Y.USA.34), Kautz Family YMCA Archives, University of Minnesota Libraries.

${ }^{100}$ Ibid., preface. 
Associations, Financial Management of Associations (a chapter printed singularly from the larger association handbook), Generous Gifts (a compendium of those who made significant donations to capital campaigns), Systematic and Generous Giving, Influence and Relationships, Pledge Cards (for organizing annual donation 'subscription' drives), and Rise and Growth of the Association, to name but a few examples. ${ }^{101}$ Members thumbing the newest version of the catalogue just a few years later had the opportunity to purchase a full throated defense of financial concerns in C.K. Ober's Money a Spiritual Force in the Kingdom of God. ${ }^{102}$

Ober was a true believer in the YMCA; at twenty years old he joined and committed himself to the association following a religious awakening while stranded in a small boat off the coast of Newfoundland for eight days. Initially he worked to recruit other college students to his local chapter, which evolved into helping colleges build chapters, morphing into crafting a curriculum to prepare recent graduates for service as local General Secretaries. Eventually he assumed chief executive positions for the YMCA in Atlanta, then Chicago, followed by New York. By World War I he was considered the preeminent man in the field, resulting in his appointment as director of American YMCA operations for the troops in England and France. ${ }^{103}$ When he wrote in

${ }^{101}$ These entries are located in the catalogue, in the order given, on pages 31,17 , $15,23,12,16$, and 38 .

${ }^{102}$ C.K. Ober, Money a Spiritual Force in the Kingdom of God (The International Committee of Young Men's Christian Associations: New York, 1903). Stewardship, 1890-1915, Miscellaneous YMCA Research, Planning, and Development Records (Y.USA.34), Kautz Family YMCA Archives, University of Minnesota Libraries.

103 'C.K. Ober is Dead; Y.M.C.A Pioneer, 92: 'Master Recruiter,' Regional Secretary 40 Years, Was an Associate of John R. Mott," The New York Times, Jul. 15, 1948, 23. 
1903 concerning the importance of money to the work of the organization, he did so from a position of authority and experience.

His nine page treatise conveyed two distinct features of the YMCA's corporate culture. First, that as a business, which is what each individual association was at its base regardless of their mission, generating revenue was key to success. Second, that the organization fully embraced the corporate nature of American culture to the point that it elevated revenue to a place of prominence within the spiritual experience. This is not to say that there were not dangers to money, Ober reminds us that "the love of it reaches to idolatry, the eagerness to make it is all absorbing, men sell their soul for it, and it is the dominant material force in this world." ${ }^{104}$ He notes that much of Jesus' criticism of humanity centers on love of money and petty greed. This, the author warns, must be avoided. Yet, Ober cannot help but view the relationship of congregants to Christ in corporatist terms, noting that Jesus brings souls into the Kingdom of God not just as "heirs...but joint partners with Christ in His present enterprise of saving the world through gospel." ${ }^{105}$ Since the Kingdom of Jesus was an enterprise, like any enterprise, it required money to function.

In fact, Ober placed cash as an equivalent to prayer in the theology of Christianity, claiming that "offerings of service and gifts, though insignificant of themselves, become with Christ's blessing and cooperation, incredible spiritual forces... God has, therefore, associated money with prayer... which His power and blessing transmute into mighty spiritual forces." 106 With donations matching prayer, from

104 Ober, 3.
105 Ibid., 4.
106 Ibid., 5. 
the perspective of the YMCA, offerings became "... absolutely necessary to our own spiritual life and growth in Christian grace and character." ${ }^{107}$ As if Ober's interpretation of the gospel did not make the organization's celebration of capitalism and corporate culture explicit, he doubled down in noting that like prayer, everyone has money to give, "for money is the universal measure of the value of man's time."108 Men who did not receive compensation for their time, we are left to assume, like their time, possessed no value. Or at least were not members of the YMCA and therefore not part of his intended audience.

Perhaps sensing that some among the men receiving this missive might balk at its message, Ober ends by acknowledging that money was viewed by many as tainted or sinful. But he offered a plan for that. "Another means by which we should seek to emancipate our members from false conceptions of money and release this for the Kingdom of God, is" with this next section presented in all caps to emphasize the importance of the point, "by doing everything possible to lift money, the art of getting it and the act of giving it, out of the realm of the material and the mechanical and into a spiritual atmosphere and treatment." ${ }^{109}$ He goes on to discuss the importance of celebrating donations, recognizing them as a source of spiritual power, and honoring contributions through appropriate financial management and thoughtful financial policies, and reminding YMCA chapters to avoid degrading donations by taking on debt. ${ }^{110}$ All of which is to say, protecting donations by maintaining a strong corporate
${ }^{107}$ Ibid., 6.
108 Ibid., 7.
109 Ibid., 9.
110 Ibid. 
culture. To Ober, it was a spiritual imperative. But what about the YMCA membership? While the Kautz Family YMCA Archive at the University of Minnesota houses a number of artifacts that demonstrate controversy within the organization, on this pamphlet the historical record is silent. It appears that this interpretation of the gospel through the lens of capitalism was met with acceptance.

Local chapters did not seem to explicitly dive into a theological proposition positioning cash with prayer - but they did express the corporatist ethos projected by the national association via prescriptive literature. This is instructive; by design the national coordinating organization could only advise and instruct. It lacked any directly coercive power at all. When local chapters adopted the methods and perspective recommended by the national organization that became an act of corporatizing from the bottom. The examples of local YMCA's embracing the organization's position within the market economy, adopting modern financial management and fundraising practices, and ensconcing a corporate culture, are almost overwhelming. Examining a handful makes the connection clear.

In 1887 the town of Alton, Ohio went about organizing a local YMCA. Reflecting the advice of Erskine Uhl ten years earlier, prior to holding meetings or planning programming, the organizing committee sought funding for a building. The materials they circulated to the city promised a fully stocked reading room, a modest gymnasium, and plenty of fraternity. All they needed, from the citizens of the community, was funding. Without subscriptions equivalent to their projected costs, $\$ 1,500$, the committee would abandon the project and all collected funds would be returned. They even went so 
far as to write into the association's constitution that it was not allowed to take on debt. ${ }^{111}$ Uhl would undoubtedly applaud this plan.

The following year the YMCA of Abilene, KS celebrated their first year in operation by taking to heart W.K. Jennings' encouragement to keep the community informed of their activities by printing an annual review. In that year they reported more than 5,000 men attended Sunday afternoon prayer sessions, 840 visited for boys' programming, there were more than 6,000 visits to the reading room, and forty-two young men attended bookkeeping classes. With 160 members of the association, they were able to report $\$ 1,985.16$ in revenue and $\$ 1,985.11$ in expenses, for a yearly profit of five cents - a notable achievement for a new YMCA. They also presented an estimate for the following year, making possible Jennings' suggestion to curtail expenses early if fundraising was falling short; that fiscal year would require $\$ 2,200$ in revenue to meet costs. ${ }^{112}$

The YMCA of Santa Cruz, California adopted a monthly newsletter as their method of communicating with members, donors, and the general community. In their second volume, from June of 1889 , the chapter provided a breakdown of the organization by the numbers: in May, 698 men visited headquarters; thirteen attended the meeting of the Board of Directors; nine new members enrolled and existing members referred three men for membership; a social gathering attracted approximately 150 attendees, while

111 "The Citizen Will Decide: Whether Alton Shall Have a Y.M.C.A., With a Well-Furnished Reading Room and Parlor, and a Well-Equipped Gymnasium, and the Accompanying Benefits," 1887. Alton, Bowling Green, Corning, Local YMCAs (Y.USA.66), Kautz Family YMCA Archives, University of Minnesota Libraries.

112 "First Annual Report of the Young Men's Christian Association of Abilene, Kansas," 1888. Kansas YMCAs, Local YMCAs (Y.USA.66), Kautz Family YMCA Archives, University of Minnesota Libraries. 
more than 400 attended a religious lecture. ${ }^{113}$ To help offset the cost of publication, the YMCA reserved space for advertisements related to local businesses and services.

Members were directed to visit Band \& Box Shaving Halls, located two doors down from City Bank; Brigeman and Whittler, purveyors of pianos, organs, and sewing machines; and most reflective of the memberships' desire to be successful in the world of Commerce, Chestnutwood's Business College. In an effort to prepare "young men and ladies for the various business affairs of life," the college offered "business training that will fit any business." Which included a curriculum focused on bookkeeping, business correspondence, commercial law, and mathematics. ${ }^{114}$ At the very least, Chestnutwood's Business College assumed they might find an audience among the men of the YMCA.

The YMCA of Greensburg, Pennsylvania, following its launch printed the first of many annual yearbooks. Immediately when opening the publication's readers were presented with a highly structured corporate body. A full Board of Directors, supported by a Board President, First Vice President, Second Vice President, Full-time General Secretary (effectively an executive director), which in turn supported the work of programming committees covering a wide-range of chapter activities - membership, finance, reading room, physical activity, visiting the sick, entertainment, spirituality, education, and even women's programming - all resulting in an efficient and financially stable organization. ${ }^{115}$ In the association president's annual message, though each chapter

113 "Work in Our New Home," The Echo, Vol. II, June 1889, 4. Santa Cruz, CA, Local YMCAs (Y.USA.66), Kautz Family YMCA Archives, University of Minnesota Libraries.

114 “Advertisements," The Echo, Vol. II, June 1889, 9-10. Santa Cruz, CA, Local YMCAs (Y.USA.66), Kautz Family YMCA Archives, University of Minnesota Libraries. ${ }^{115}$ First Year Book of the Young Men's Christian Association of Greensburg, PA (Young Men's Christian Association: Greensburg, PA, 1890), 2-5. Pennsylvania: 
was sovereign, Paul H. Gaither placed the new Greensburg chapter in the context of a larger whole, commenting that it was "simply a branch of a great system." ${ }^{116} \mathrm{~A}$ significant part of fitting into that system, as the prescriptive literature guided, was conveying the work of the organization. Following the path set by other chapters and annual reports, Gaither took the time in his message to detail the organization's activities by the numbers: they conducted eighty-five prayer meetings, attended by 303 men; fortysix Sunday afternoon sessions were held, with more than 3,000 participating; the gymnasium was available thirty-eight evenings, resulting in 918 members utilizing the new facility; while the association's baths operated for forty-eight days, serving 384 men. All in all, the first year of operations was an undeniable success. Yet, Gaither reminded the annual report's audience, they could not rest. Those who supported the mission of the association, seeking to maintain its financial stability in pursuit of their goals, must not "stay their hands."117

A collection of newsletters from 1891 produced by the YMCA chapter in Sedalia, Missouri echoes the same formulas for success encountered elsewhere. Throughout the year they provided their members and supporters updates on the construction of a new headquarters, erected in sections, as funds allowed - being careful to avoid debt at all cost. Even in planning to acquire furnishings for the building, estimated at $\$ 1,000$, a special collection drive at local churches replaced the possibility of purchasing on

Greensburg Folder I, Local YMCAs (Y.USA.66), Kautz Family YMCA Archives, University of Minnesota Libraries.

116 Ibid., 6.

117 Ibid., 11. 
credit. ${ }^{118}$ In December, still working on securing funds to complete construction, the association announced a lecture and entertainment series for 1892 . For the low, but paid upfront, cost of \$2, Sedalians experienced the "Orpheus Quartette," a guitar and Mandalorian troop, the "Ariel Ladies Quartette," a singing group, and a lecture from Charles F. Underhill, "a master of pathos and humor with an apparently inexhaustible repertoire." ${ }^{119}$ The adoption of the corporate approach to managing the organization is not surprising, either in the evolution of the YMCA in general, or in the development of the chapter in Sedalia, Missouri. Two years prior, in the September 1890 issue of the newsletter, the association made clear their role in the market economy. In previewing the year ahead, the anonymous author of the front page article asked the membership, "are you calculating in your 'fall budget' just how much time you are going to give to the work of leading your fellow young men to Jesus Christ?" ${ }^{20}$ Again, the link between the spiritual and businesslike is undeniable. So much so that the article critiques the approach of the organization as having been not corporate enough, asserting that they have "been haphazard." ${ }^{121}$ While the membership gave of their time when convenient, it was time for the enrolled men to sacrifice more, as "the Christian young men of Sedalia are

118 The Tie (Young Men's Christian Association of Sedalia, MO: Sedalia, MO, May 1891), 1-3. Kansas: Sedalia, Sterling, Wichita [Sedalia, MO is incorrectly included in this collection], Local YMCAs (Y.USA.66), Kautz Family YMCA Archives, University of Minnesota Libraries.

${ }^{119}$ The Tie (Young Men's Christian Association of Sedalia, MO: Sedalia, MO, December 1891), 1. Kansas: Sedalia, Sterling, Wichita [Sedalia, MO is incorrectly included in this collection], Local YMCAs (Y.USA.66), Kautz Family YMCA Archives, University of Minnesota Libraries.

${ }^{120}$ The Tie (Young Men's Christian Association of Sedalia, MO: Sedalia, MO, September 1890), 1. Kansas: Sedalia, Sterling, Wichita [Sedalia, MO is incorrectly included in this collection], Local YMCAs (Y.USA.66), Kautz Family YMCA Archives, University of Minnesota Libraries.

${ }^{121}$ Ibid. 
responsible to the business men who have supported and are still supporting the work." "122 With the investment being made by the business community of the city, it was now their responsibility to honor that commitment with a businesslike approach.

While the historical record is replete with local chapters that took the direction of the national association seriously, few offer a window onto this mindset provided by the association organized in Kane, Pennsylvania. In the years immediately following the turn of the century, the Kane YMCA demonstrated not just a corporatist mindset in the management of the organization, but projected it onto its members.

In terms of management, the local YMCA followed the beat of the corporatization drum, incorporating a number of the strategies already encountered. They maintained a large directing board, populated by local merchants. The governing board elected officers and provided a salary for a General Secretary who managed the association's day-to-day affairs. ${ }^{123}$ They utilized an annual entertainment program, branded as "The Star Course," to fuel fundraising and external interest in the organization. ${ }^{124}$ Also left behind for researchers are a number of cards used by the organization to register future donations. One, from 1907, asked donors to pledge financial support, "sixty days after date, or on demand." 25 Another fundraising instrument, asking for a pledge of support as well, makes clear that it would be used only in "liquidating the present indebtedness" of the

122 Ibid.

${ }^{123}$ Annual Announcement, 1904-05 (Kane, PA Young Men's Christian Association: Kane, PA: 1905), 6. Pennsylvania: Grove City, Kane, Lewistown, Local YMCAs (Y.USA.66), Kautz Family YMCA Archives, University of Minnesota Libraries. 124 Ibid., 24.

125 Subscription Card, 1907 (Kane, PA Young Men's Christian Association: Kane, PA 1907). Pennsylvania: Grove City, Kane, Lewistown, Local YMCAs (Y.USA.66), Kautz Family YMCA Archives, University of Minnesota Libraries. 125 Ibid., 24. 
association - the first sign that perhaps this YMCA did not always color within the lines provided by the national association. ${ }^{126}$ The last of these cards, a true curiosity among YMCA records, reminded past due members that they held an outstanding debt to the organization. ${ }^{127}$ Regardless of the acknowledgement of a debt on the books, clearly this YMCA was approaching their operations in a strategic, thoughtful, corporate manner. Little surprise that they made use of the primary tool for maintaining members; a well apportioned gymnasium, including a modern bathing facility. Pictures of both were even included in their annual review (perhaps not the best use of illustration as the showers resemble a medieval torture chamber, at least to modern eyes). ${ }^{128}$

What makes the Kane YMCA remarkable, however, is the extra step they took in emphasizing the corporate nature of the organization by extending it to their conception of their members. Most YMCA's acknowledged the desire for upward mobility among their membership, usually through the nature of courses offered in preparation for an office vocation. In Kane, the assumption became that all full members were engaged with the market economy. For those not old enough to vote, little lone engage in business, membership was offered at the 'junior' level. Slightly older, but not yet established members qualified for enrollment as a 'senior.' Full membership, which conferred no special privileges from 'senior' members other than the right to participate in the decision

${ }^{126}$ Debt Subscription Card, 1907 (Kane, PA Young Men's Christian Association: Kane, PA 1907). Pennsylvania: Grove City, Kane, Lewistown, Local YMCAs (Y.USA.66), Kautz Family YMCA Archives, University of Minnesota Libraries. 126 Ibid., 24.

${ }^{127}$ Kane, PA, November 18, 1907 (Kane, PA Young Men's Christian Association: Kane, PA 1907). Pennsylvania: Grove City, Kane, Lewistown, Local YMCAs (Y.USA.66), Kautz Family YMCA Archives, University of Minnesota Libraries. ${ }^{128}$ Ibid., 7-8 \& 36. 
making of the organization, was termed 'businessmen.' ${ }^{129}$ Yet, these membership levels were not without meaning. They determined gymnasium activities in which men could participate. Both the pocket sized athletics schedules for 1906 and 1907, shaped and sized to replicate a business card, made a definitive distinction. 'Juniors' attended organized workouts Mondays from 4-5:30 pm and Saturdays from 9-11 am. The gymnasium was reserved for the use of 'seniors' on Mondays and Wednesdays from 8-9:30 am.

'Businessmen' were scheduled always after four on Tuesdays and Fridays. ${ }^{130}$ This did not include specially organized athletic competitions and leagues. For 1907 and 1908, the chapter's basketball and baseball schedules included bouts between 'Businessmen' baseball teams organized within the area, and the same for high school students regardless of their membership level. ${ }^{131}$ Opportunities appear equal between the membership levels in terms of playing time, while the 'Businessmen' teams carried one honor unavailable to the others: emphasizing the idea of the YMCA being a business for businessmen, only those athletic teams organized for full members, found their pictures placed in the annual review.

${ }^{129}$ Application for Membership (Kane, PA Young Men's Christian Association: Kane, PA c. 1901-09), 2. Pennsylvania: Grove City, Kane, Lewistown, Local YMCAs (Y.USA.66), Kautz Family YMCA Archives, University of Minnesota Libraries. ${ }^{130}$ Schedule of Gymnasium Classes, 1906-07, of the Kane Young Men's Association (Kane, PA Young Men's Christian Association: Kane, PA 1906), 1 and Schedule of Gymnasium Classes, 1907-08, of the Kane Young Men's Association (Kane, PA Young Men's Christian Association: Kane, PA 1907), 1. Pennsylvania: Grove City, Kane, Lewistown, Local YMCAs (Y.USA.66), Kautz Family YMCA Archives, University of Minnesota Libraries.

${ }^{131}$ Kane Y.M.C.A Basket and Baseball '07 and '08 Schedule (Kane, PA Young Men's Christian Association: Kane, PA 1907), 1. Pennsylvania: Grove City, Kane, Lewistown, Local YMCAs (Y.USA.66), Kautz Family YMCA Archives, University of Minnesota Libraries. 
Regardless of the Kane YMCA's evolution of the corporate nature of the organization to the point of morphing ideals of membership and belonging, this chapter fits into the mold already developed. With the Young Men's Christian Association we find an example of the adoption of a corporate culture, again and again, across the nation, from the 1870 s to 1910 , from those in the middling class - just as Zunz found in his examination of for-profit corporations. Those in the trenches of securing a Young Men's Christian Association, often without the resources to do so in isolation from the community, adopted the lessons of the prescriptive literature as the best path forward. Though it encouraged corporatization, the national coordinating body purposefully lacked the tools to coerce a corporate culture or any particular program, management approach, or perspective. Yet, the decision to conform to a corporate management structure - to apply a modern definition of professionalism within business operations - was affirmed countless times in various locations. It was not just the most efficient and prudent method of administering a chapter, it spoke to the aspirations of the largely middle class men who inhabited the membership rolls.

Mentioned little in most of the YMCA's historical record, at least when it comes to the corporate nature of the organization, is the role played by women. Certainly, a significant role was played by women, even if often downplayed by the men. The chapter in Kane, Pennsylvania, for example, hosted an active and largely attended 'Ladies Auxiliary.' In 1905 they reported that 'the boys and young men have long since learned to know the place [the Ladies auxiliary] occupy in the various banquets and social events 
held during the year." ${ }^{132}$ While times were held open for the women of the YMCA to utilize the gymnasium as well, their real goal as an auxiliary was "to see that the rooms are kept in a home-like condition, to provide for such banquets, socials and other entertainments as the work requires, and to assist in any way within their power, in conjunction with the Directors, in building up the work in general." 133 But this was unusual among charitable organizations in the period. Often, women held leadership roles, especially in local organizations. Conceivably, this place as caretaker and helpmate, similar to women's role within the domestic sphere is reflective more of the YMCA's status as an association for men. But as demonstrated in the evolution of the American Red Cross, the status of women within the YMCA reflects the role of women within the corporatized nonprofit landscape: present, but with agency diminishing as the corporate culture matures.

${ }^{132}$ Annual Announcement, 1904-05, 31. (Kane, PA Young Men's Christian Association: Kane, PA 1907), 1. Pennsylvania: Grove City, Kane, Lewistown, Local YMCAs (Y.USA.66), Kautz Family YMCA Archives, University of Minnesota Libraries. 133 Ibid. 


\section{Chapter 7}

The American National Red Cross

"Recently the Rev. R.A. Holland, of Trinity Church [Boston] preached a sermon to young women," Catharine Cole of New Orleans, Louisiana reported to the readers of the Times-Picayune in 1884. "'He was listened by one of the largest congregations ever gathered within the walls of old Trinity. His audience was a fine selection from the most successful classes of society."2 Cole informed her readers the sermon was quite good, "very beautiful...very elegant... a train of thought that must have been very grateful and soothing to many women...all meekness and gentleness and humility."3 Cole, however, was none of those things, and rather than soothed by his words, she became incensed. "Compressed into my ruder English," she informed her audience, "the sum and substance of Dr. Holland's address was that the home is woman's sphere that all her talents, genius, art, education, skill, ambition, must be expended in the home for the home."4 She continued, "where man is to have bravery and courage, the woman is to have meekness and humility; where she wishes to share any of 'the privileges of men,' she is laboring under 'a wretched delusion."5 Holland's suggestion that women facing world be "acknowledged and treated as queens and princesses still, though in exile," seemed ludicrous. ${ }^{6}$

${ }^{1}$ Cole, Catherine, “A Sermon to Young Women," New Orleans Times-Picayune (New Orleans, LA), Mar. 23, 1884.

${ }^{2}$ Ibid.

${ }^{3}$ Ibid.

${ }^{4}$ Ibid.

${ }^{5}$ Ibid.

${ }^{6}$ Ibid. 
Cole noted that many women in the South - a region still recovering from the ravages of war-faced difficult circumstance or chose to confront the world alone. "Her ambition, her inspiration, her genius, her need may have led her to adopt a vocation beyond the sanctuary of her home," the author noted, "must it also follow that she adopt a cringing, deprecating, hope-I-don't intrude manner, and be eternally apologizing because she is successful or trying to be successful at some work in which her interests are centered?" Cole stated, "I do not believe that when women adopt occupations unusual to the sex, and which they fulfill nobly and honorably, that it is just not an accident."7 To prove her point, she highlighted a number of women operating, quite successfully, outside of the home in the realm of men. Her most notable example was Clara Barton. "an American Florence Nightingale, who nursed and cared for soldiers on the field of battle, and who now at the head of the Red Cross society is carrying succor to sufferers by flood in the Ohio Valley." ${ }^{8}$ In Barton, the author Cole found the perfect foil to Holland's argument; Clara Barton's life was truly remarkable.

Born in 1821 in Massachusetts, Barton found the traditional role for women uncomfortable. When the Civil War moved from small skirmish to all-out war, Barton volunteered as a nurse, working with and learning from the United States Sanitary Commission as the war progressed. Following the war, she set about identifying the graves of unknown soldiers, eventually traveling overseas for respite, but instead finding herself caught in the middle of the Franco-Prussian War. Thanks to a friendship with Grand Duchess Louise of Baden, who organized medical care for injured soldiers and

\footnotetext{
${ }^{7}$ Ibid.

${ }^{8}$ Ibid.
} 
provided funding to the nascent Red Cross' societies in Central Europe, Barton returned to the United States certain that more needed to be done. Inspired by her second war experience, she began advocating for her nation to sign on to the Geneva Convention and found a national Red Cross organization.

The Geneva Convention remained unsigned until 1882, and the Red Cross did not receive recognition as the nation's representative relief organization, so Barton launched a shoestring version in 1881. Unlike European counterparts, she presented a novel idea: to keep the organization active, efficient, and ever ready, instead of waiting for international conflicts that included the United States as a combatant. The American version of the Red Cross would respond to disasters, natural and unnatural alike. Foregoing dormancy unlike organizational counterparts elsehwere, the Red Cross would remain sharp and active, learning more about mitigating disasters and managing resources efficiently and quickly.

Barton's leadership in relief work so was widely recognized that, at least when it came to disaster mitigation, the federal government turned coordination on the scene to her, resurrecting a part of the Associational State evident during the Civil War. That came in spite of the fact that Barton refused to transform her initial idea into a functional nonprofit corporation. The Red Cross remained small, informal, and completely fueled by the presence of Barton. By the turn of the century, as statesmen and philanthropists took a stronger interest in the organization's mission, dissatisfaction with Barton's approach spread, eventually creating factionalism and public conflict. Without her vision and leadership it is likely that the American Red Cross would not have materialized at all. 
Her impact on the nation was undeniable and as observers, both contemporary and modern remarked, Barton was a force of nature seemingly capable of overcoming all challenges. Except for her gender. Born into a world in which women lived in circumscribed space, both socially and physically, Barton often existed in the undefined space between society's norms. Expected to focus on the needs of the home and family once married, she avoided subsuming her ambition by never marrying. With the coming of industrialization and the opportunities and challenges it created, women's role in society expanded as conceptions of the home expanded to include the morality and propriety of the community. Some women chose to interpret their role as mother wider than direct motherhood, and to these tanks Barton certainly belongs. And while these women escaped criticism of their paths, the space to pursue their goals existed within the wider culture. ${ }^{9}$ While the American Red Cross remained an informal organization, Barton's leadership remained unremarkable. But if the Red Cross were to transition to a nonprofit corporation with a meaningful corporate culture, Barton's position suddenly became untenable.

When the advocates of a modern, corporatized Red Cross began pushing for change, Barton's gender became an obstacle. With a woman at the helm - as reflected in the Reverend Holland's sermon - the forces of business remained uncommitted to the organization. Criticism of the organization's lack of a businesslike approach came even though the Red Cross made the restoration of economic independence the cornerstone of relief efforts, setting it apart from both local and federal government efforts. Though the

${ }^{9}$ Linda K. Kerber, “Separate Spheres, Female Worlds, Woman's Place: The Rhetoric of Women's History," The Journal of American History, Jun. 1988, 10-11. 
Red Cross remained a supporter of the market economy it failed to adopt the culture of the market economy. Prevented by Barton's preference for informal organization structures and controls, and her gender preventing her from being accepted as the leader of a truly corporatized nonprofit organization, the founder was jettisoned to make way for a man.

In early September 1881 near the Michigan townships of Richmondville, Western, Forester and Marion - approximately seventy-five miles east of Saginaw, Michigan - a forest fire of massive proportions brought hell to the residents of that rural section of the state. The stories from the survivors, as well as the evidence of the aftermath, were harrowing. Bodies were found drowned in wells where they sought escape. It was not uncommon to discover entire families strewn about a road in the forest, near a homestead, falling as they struggled for safety. As the fire spread, eventually overtaking the small city of Port Huron, the casualties increased. In the aftermath it was hard to gather precise data. Port Huron was thought to have lost at least 1,000 inhabitants. Few buildings remained standing. ${ }^{10}$ By the time the fires were extinguished an estimated 15,000 were homeless throughout the state. With economic production largely home based in rural Michigan, this did not simply mean homelessness; this loss was a blow to the already weak economic foundation of this area and made economic independence an impossibility. Relief committees sprang into action throughout the state, with Detroit leading the way. Other cities joined in the effort. The Mayor of Goderich, Ontario

10 "The Michigan Forest Fires," Southwestern Christian Advocate (New Orleans, LA), Sept. 15, 1881. 
organized a committee to collect supplies for the victims. Memphis, Tennessee raised $\$ 1,500$ in relief funds, as well as donated a mule to be auctioned and reauctioned as it made its way to Cincinnati, where it was auctioned one last time. New York City organized a relief committee, raising more than $\$ 22,000 .{ }^{11}$

Even the former Confederate states, still recovering from the social and economic upheaval of the Civil War, answered the call. In some ways the suffering in Michigan may have spoken directly to the Southern heart. Noting that the victims needed shelter, food, and clothing, especially with winter quickly approaching, the Georgia Weekly Telegram added that they needed their economic independence restored through seed for the spring and draft animals. It reminded readers that "we are not rich, but certainly not so poor as to be unable" to return the charity provided following the war, after all, Southerners, "know what it is to suffer and need the very necessities of life." ${ }^{12}$ In closing, the author assured readers "if no local agent is at hand, contributions sent direct to Hon. Wm. G. Thompson, mayor of Detroit, will be faithfully applied."13 In many a future disaster Americans would come to expect the Red Cross to serve as the conduit between donors and victims. But not yet - at least not universally. In 1881 the Red Cross, recently formed, sprang into action to alleviate the Michigan forest fires. Too new to create the kind of well-managed relief effort that characterized the organization through much of its history, and not yet exhibiting the kind of corporate culture that eventually developed, the

11 "An Appeal: To the Human of the United States," Cleveland Daily Herald (Cleveland, Oh), Sept. 15, 1881.

12 "The Michigan Fires," Georgia Weekly Telegraph (Macon, Ga), Sept. 23, 1881.

${ }^{13}$ Ibid. 
challenge of addressing the Michigan forest fires demonstrated the need for a national disaster response coordination body.

Shortly after the creation of the relief committee in Detroit, its efforts were coopted by the Governor of Michigan, who issued a call for additional charity. Though the citizens of the state answered the call for the immediate needs of the victims, "ample time has expired, and sufficient details have been received, to make it evident that a wider appeal is needed." ${ }^{14}$ While cash donations were highly prized, Gov. David Jerome highlighted the need for quality goods, making almost any donated items valuable, "whatever will enable them to go through the coming winter and to become again an independent community." ${ }^{15}$ Clearly economic independence was at the forefront of those leading the recovery. As was the need to ensure donors that their contributions would be used earnestly and efficiently - a reoccurring theme in late $19^{\text {th }}$ century disaster rhetoric. In this case, Jerome promised his audience, the relief committee "is composed of wellknown, competent, and responsible citizens" who created "systematic plans of relief."16 Undoubtedly well intentioned, the historical record makes clear that this relief effort, like so many that would follow, was far from systematic.

Word of the devastation and the needs of the victims was disseminated far and wide as stories of survival and struggle were printed almost daily in newspapers across the nation. The St. Louis Globe devoted a full foot of the frontpage to telling such tales like that of a farmer from Sand Beach, who found himself suddenly surrounded by

${ }^{14}$ Jerome, David H, "The Michigan Calamity," Independent Statesman (Concord, NH), Sept. 22, 1881.

15 Ibid.

${ }^{16}$ Ibid. 
flames. Fighting his way back to his home, he managed to gather his family, and made a mad dash to safety. Working through smoke and flame the family became separated, with the farmer making it away from the flames with two small daughter in tow. The following day he found the bodies of the rest of his children and wife, all having succumbed to smoke inhalation. ${ }^{17}$ As far away as Galveston, readers of the local newspaper were horrified to learn "of special places of refuge there seems to have been none; even had there been it is doubtful whether, in the anxiety of the startled farmers to save their homes, they would have been resorted to until too late." 18 The problem, they observed, "for smoke and heat suffocate human beings so quickly that it is unlikely that many of the victims were conscious when the flames reached their bodies." 19 Even a brief telegram from the Mayor of tiny Bay City, Michigan found its way into Chicago's Daily Inter Ocean, informing readers that "immediate aid is asked. Five thousand families are naked hungry. The suffering is terrible. You cannot form any idea without seeing it."20 Providing information was the easy part. Relief getting in, especially where it was actually needed, proved more difficult.

When news of the calamity reached beyond rural Michigan communities to the rest of the country - especially the upper Midwest and Northeast - local committees began to raise funds and collect household items. In New York City a committee launched on September $10^{\text {th }}$, with a focus on raising cash instead of goods. ${ }^{21}$ In

17 "Heart Rending Holocaust," The St. Louis Globe-Democrat (St. Louis, MO), Sept. 10, 1881. $14,1881$.

18 “Michigan's Scourge of Fire," Galveston Daily News (Galveston, TX), Sept.

${ }^{19}$ Ibid.

20 "Chicago Sympathy," Daily Inter Ocean (Chicago, IL), Sept. 12, 1881.

21 "Relief," Cleveland Daily Herald (Cleveland, OH), Sept. 12, 1881. 
Milwaukee the relief committee, perhaps taking into account their proximity to the crisis and decreased transportation costs compared to elsewhere, focused on collecting household items. Chicago's Board of Trade took the lead in the Windy City's efforts, pulling $\$ 2,500$ together just from their membership and putting out a call for clothing donations; all of which was transported free of charge via railroads headquartered there. The Cincinnati Chamber of Commerce raised $\$ 2,000$ for the effort, with a vague promise of future gifts. ${ }^{22}$ The Business Men's Association of Oshkosh, Wisconsin raised \$1,000 among its members. ${ }^{23}$ The Lumbermen's Association of Tonawanda, New York collected $\$ 655 .^{24}$ The citizens of Massillon, Ohio raised $\$ 150$ and a pile of clothing..$^{25}$

While such efforts were undoubtedly motivated by a desire to ease suffering among the victims of the fire, collecting the funds was the easy part. Without a national organization coordinating a relief effort, each city and group was left to independently determine where to send their support. The Governor, who might be expected to lead the effort, instead delegated that responsibility to the Detroit Relief committee. But the relief committee working out of Port Huron, Michigan was closer to the action. This produced a splitting, instead of concentration, of resources. That is assuming plans for funds raised were executed. The Lumbermen's Association of Tonawanda send their $\$ 655$ to the Port Huron committee. ${ }^{26}$ While the New York Board of Trade failed to identify a destination for the more than $\$ 20,000$ they raised. They left the question up to the group's officers, 1881.

22 "Relief for Michigan," Milwaukee Daily Sentinel (Milwaukee, WI), Sept. 14, 23 “Multiple News Items," Milwaukee Daily Sentinel (Milwaukee, WI), Sept. 21, 1881.

24 “Another Appeal," Milwaukee Daily Sentinel (Milwaukee, WI), Sept. 15, 1881. 25 "The Fire Record," Cleveland Daily Herald (Cleveland, OH), Sept. 14, 1881. 26 “An Appeal," Cleveland Daily Herald (Cleveland, OH), Sept. 15, 1881. 
who left it unstated. ${ }^{27}$ As much as Cleveland's newspapers reported the beneficence of other cities, their Board of Trade determined to "correspond with the proper parties and ascertain if the Michigan sufferers by fire need money, and if so, appropriate a generous sum from the Board Treasury." ${ }^{28}$ The outcome of their efforts went unreported. On the same day that the Cleveland Board of Trade undertook to investigate, a member of the Governor of Ohio's staff submitted reports to the state's government, resulting in the decision to remain at the scene of the crisis to coordinate aid arriving from the state. ${ }^{29} \mathrm{~A}$ remarkable step considering that few relief efforts even bothered to identify a destination for their collection. It is perhaps the experience of Chicago that best demonstrates the obstacles to decentralized relief efforts.

September $12^{\text {th }}, 1881$, Mayor Carter H. Harrison issued a proclamation to the citizens of Chicago, informing them that the harrowing tales from rural Michigan were accurate and needed to be acted upon. Echoing a number of elected executives from cities and states across the United States, Harrison acknowledged that requests for assistance were rolling into his office. "The city's charter gives me no power to grant such relief. I therefore call upon the good people of Chicago to forward at once," and like was done for Chicago ten years earlier when they experienced a devastating fire, "and take such steps as may be necessary to render substantial aid to the distressed people of Michigan. ${ }^{\prime 30} \mathrm{He}$ implored residents of the city to "come forward at once and retain their grand reputation...contributions should be made promptly" only to acknowledge that prior to

27 "Relief," Cleveland Daily Herald (Cleveland, OH), Sept. 12, 1881.

28 "Heart-Rending Holocaust," St. Louis Globe-Democrat (St. Louis, MO), Sept. $10,1881$.

${ }^{29}$ Ibid.

30 “Chicago Sympathy,” Daily Inter Ocean (Chicago, IL), Sept. 12, 1881. 
making their generosity actionable they would need "correspondence entered into to learn how best to apply relief." ${ }^{31}$ Regardless of the details left undetermined, other voices chimed in to support the effort. The Daily Inter Ocean suggested to readers that "in the interest of common humanity Chicago in her prosperity should contribute liberally to alleviate the sufferings, and restore as far as possible what these people have lost." 32 Drawing on memories of their own fire ten years prior, the newspaper asked "what could more appropriately demonstrate to the world the appreciation felt in this city for the benevolence that came in the hour of her need than a liberal thank offering." ${ }^{\prime 3}$ The urgency of crises, however, dissipated quickly, especially when plans were deferred, and it appears that Chicago instead of coming to the aid of rural Michigan slipped into complacency. The Daily Inter Ocean was embarrassed to report "a great many severe comments are by the press of other cities upon the...sum that the people of Chicago have to the sufferers" ${ }^{\prime 4}$ The editors even went as far as to print an excerpt from the New York World, bemoaning that "the failure of the businessmen of that great city to contribute to the relief of the unhappy people... is not such a story as the East is accustomed to hear from the great West." ${ }^{35}$ In reflecting on the city's lack of action, the author found "the fault lies in a lack of system in raising contributions, not in the absence of a liberal spirit." 36 They found that the committee charged with organizing Chicago's charitable efforts "seem not to have entered upon the work with the usual Chicago enthusiasm, and

${ }^{31}$ Ibid.

32 “Multiple News Items,” Daily Inter Ocean (Chicago, IL), Sept. 9, 1881. 33 Ibid.

34 “As Might be Expected," Daily Inter Ocean (Chicago, IL), Sept. 20, 1881.

${ }^{35}$ Ibid.

${ }^{36}$ Ibid. 
hence the contributions have come slowly." 37 With the city's reputation on the line, for the Daily Inter Ocean it was no longer about charity but instead "to show that these criticisms are not well founded." 38 Three days later the Milwaukee Daily Sentinel reported the Daily Inter Oceans worst fears were realized; the committees appointed to muster Chicago's energies and generosity failed to meet, and all the city had to offer the fire victims was a paltry $\$ 2,700$ raised by members of the Lumberman's exchange. Perhaps one part news and one part criticism of a rival city, the unnamed author concluded his report by noting "it seems as if the matter will be allowed to lapse."39 Chicago's struggle in finding focus was not the only mishap related to raising funds for the relief of the fire victims. Toward the end of September, 1881, the Veiled Prophets of St. Louis, a service organization that raised money each year through a fundraising ball, designated Michigan fire relief as their annual cause. "They promise a grand spectacular procession," reported the Southwestern Christian Advocate, "and a lavish expenditure of money."40 The report mused that the cash spent for the event, "probably half enough to relieve the sufferers of the Michigan forest fires, or enough to found a college if so used, but will disappear as rain through a sieve." 41 The funds actually raised went undisclosed, but it sounds as if the event were a social success. Further demonstrating the possibility of the farcical in relief efforts, the village of Bad Ax, two months after the fire, found itself awash in offers for erecting replacement

\section{${ }^{37}$ Ibid.}

${ }^{38}$ Ibid. 1881.

39 “Multiple News Items,” Milwaukee Daily Sentinel (Milwaukee, WI), Sept. 24, 40 "Multiple News Items," Southwester Christian Advocate (New Orleans, LA), Sept. 22, 1881.

${ }^{41}$ Ibid. 
church buildings: "the Baptist and Presbyterians each want to put up one building, the Methodists two, the Episcopalians another." 42 These proposals seemed to ignore that the entire population of the village, including surrounding hinterland, would fit in a single small church. ${ }^{43}$ Clearly, effective and efficient relief efforts required an organization capable of coordinating the decentralized and localized charitable efforts that are a hallmark of American democracy. Asserting its will on the process would take multiple relief responses to gain trust throughout the country, but by the time that Barton relinquished control of the Red Cross it had become the default organizer of national efforts.

But in the fall of 1881 the Red Cross remained a new organization without the systems in place to direct the relief effort. When news reached Barton concerning the plight of the Michigan fire victims, she dispatched Julian Hubbell, her right hand in future relief efforts to the area. Hubbell's reports echoed the sentiment in newspaper dispatches and encouraged Barton and a small retinue of nurses, and what might be called case managers, to travel to the scene of the crisis. Having just been created, the Red Cross lacked a national network from which to draw support. Instead, for this first relief effort, the organization functioned as an aggregator and disburser for funds and supplies raised by the three local chapters Barton chartered just prior to the fires (Dansville, Syracuse, and Rochester, New York). Yet, her efforts drew the attention of the press. ${ }^{44}$ One reporter described the Red Cross operation as "practical and laudable to the last

42 "Purified by Fire," Daily Evening Bulletin (San Francisco, CA), Nov. 28, 1881.

${ }^{43}$ Ibid.

${ }^{44}$ Dulles, 26-27. 
degree. ${ }^{45}$ Like the other endeavors in her remarkable life, Barton's management of the Red Cross quickly earned praise. The experience of Michigan fire relief, from the decentralized nature of fundraising efforts to applause for the Red Cross and Clara Barton, largely became the norm. What changed was the efficiency and complexity of the Red Cross response.

In the winter of 1884 excessive rain caused flooding throughout the Ohio River Valley. As waters receded and moved down river, above average rainfall in connected areas produced additional flooding. Between February and April communities from Illinois to West Virginia to Mississippi found themselves inundated with water and in desperate need of relief. The decentralized and uncoordinated efforts evident in the Michigan forest fires persisted, as they would in response to every natural disaster that followed during this period. The major cities of the Northeast, unaffected by the deluge, were the first to act. The Milwaukee Daily Sentinel printed a survey of their efforts: in New York City the Coffee Exchange, Importers Board of Trade, and Grocer's Board of Trade formed a combined relief committee, collecting subscriptions from members for $\$ 2,000$; a Philadelphia relief committee formed, with the goods company Drexel \& Co. appointed Treasurer, charged with determining how to disburse the funds; the Baltimore $\&$ Ohio railroad volunteered to transport goods donated to the victims of the flood. ${ }^{46}$

45 “Association of the Red Cross," Daily Inter Ocean (Chicago, IL), Nov. 12, 1881.

${ }^{46}$ Hoadly, George, “The Ohio Deluge," Milwaukee Daily Sentinel (Milwaukee, WI), Feb. 13, 1884. 
These early efforts, like those that would follow, faced the same issues present with Michigan forest fire relief. But with such a larger relief effort underway opportunities for abuse also expanded, adding a new challenge. Railroads throughout the impacted area often took the lead in distributing goods. At each West Virginia depot of the Clarksburg and Western Railroad, clothing and household items were collected and distributed for needy areas. The generosity of the people along the road, however, soon swamped the capacity of the railroad resulting in a logjam of relief. Since the railroads lacked experience in relief operations, it also did not take long before they discovered people abusing their lack of a system. Two women were arrested for fraud, who in their combined efforts acquired more than sixty outfits of donated clothing and seventeen pairs of shoes. ${ }^{47}$ Remarkably, some communities that stood to profit from relief efforts objected to receiving aid all. Paducah, Kentucky, impacted by the flooding, received donations from far and wide. A boat loaded with 30,000 daily rations came from Louisville, while Norfolk, Virginia sent the town $\$ 500$, and a Cincinnati, Ohio watch company sent $\$ 200$ collected from employees. When an offer of an additional $\$ 500$ came from Louisville as well, along with an inquiry from New York City as to what assistance was needed, both were declined, "the help already received being thought sufficient for all purposes." ${ }^{48}$ No mention is made of where these funds and inquires went next, but this demonstrates the clear inefficiency in the existing system - each individual local relief effort needed to determine the type of relief that would be most useful in the communities most in need of assistance.

47 "Ready Assistance," Galveston Daily News (Galveston, TX), Feb. 15, 1884. 48 “The Floods," St. Louis Globe-Democrat (St. Louis, MO), Feb. 23, 1884. 
One alternative to this decentralized relief effort was intervention by the federal government. With the Michigan forest fires, the area impacted was contained to a small portion of one state, without significant effect on the nation in general. It also coincided with the assassination of President Garfield, making it is unclear as to whether the federal government was even capable of responding. In 1884, with many a community underwater, the federal (and local) governments felt compelled to respond.

One of the first to act was Charleston, West Virginia, who within a day of receiving an appeal for help from towns along the ever expanding Kanawha river, allocated $\$ 500$ from the city's general operating budget, and outfitted a steamer with provisions to head in the direction of the crisis. Two days later, the City Council allocated funds for a second steamer filled with relief supplies. ${ }^{49}$ The City Council of Cincinnati acted just as quickly, appropriating $\$ 50,000$ for flood relief. ${ }^{50}$ But the real relief might came at the purse of the federal government. On February $15^{\text {th }}$, Secretary of War Robert Todd Lincoln appeared before the House Committee on Appropriations to request an additional $\$ 200,000$ in relief funds, bringing the total authorized by Congress to $\$ 800,000$. Though this would be the total amount allocated by the federal government, Lincoln expected that this would fund the relief effort for only a few weeks. Regardless, he set to work moving assets into position..$^{51}$

While the War Department may seem an odd choice to organize federal relief efforts, it was one of the few executive departments with personnel spread throughout the 1884.

49 “Higher Than Ever,” Milwaukee Daily Sentinel (Milwaukee, WI), Feb. 12, 50 "Sufferers by the Flood," Galveston Daily News (Galveston, TX), Feb. 13, 1884.

51 Ibid. 
country. Lincoln immediately called on staff officers in the vicinity of the crisis to manage the response. Thus, the impact of the support allocated by Congress was felt fairly immediately. Using Parkersburg, West Virginia as the War Department's base of operations, Lincoln arranged for a flotilla of seven steamers, with staggered departures, running up and down the Ohio River distributing clothing and supplies. Meanwhile, the commander of the garrison outside of Louisville, Kentucky sent a streamer loaded with 70,000 daily provisions in the opposite direction. The commander of the garrison in Pittsburgh, Pennsylvania likewise stocked a steamer and sent it out to provide direct relief, expending $\$ 50,000$ in funds in a matter of days. ${ }^{52}$ Unambiguously, the federal government was determined to have a positive impact on the relief effort.

In some places, where the water receded quickly, the federal response was enough. In Ironton, Ohio a relief boat arrived quickly, transferred supplies to the local relief committee which handled distribution, and local authorities mustered police and militia to maintain order and clear debris. Just three days after Lincoln appeared before Congress the commercial district of Ironton was open for business and life for many of the residents was returning to normal. ${ }^{53}$ Much could be accomplished with two steamers full of supplies and $\$ 60,000$ in relief funding - all of which were expended just on the recovery of that community. ${ }^{54}$ When flooding on the Ohio became flooding on the Mississippi the same general federal relief plan was enacted. The commanding officers of garrisons in St. Louis and New Orleans were instructed to load steamers with supplies,

52 “Aid for the Sufferers," Galveston Daily News (Galveston, TX), Feb. 16, 1884. 53 "Flood Sufferers," Milwaukee Daily Sentinel (Milwaukee, WI), Feb. 19, 1884. 54 "Ready Assistance," Galveston Daily News (Galveston, TX), Feb. 15, 1884. 
stagger their departures, transmit rations and aid to local relief committees as they went, and meet somewhere in the middle. ${ }^{55}$

Due to the size of available funds and the reach of personnel stationed throughout the country, the federal government was able to impact the situation immediately. But the War Department was only able to act within the confines of legislation passed by Congress. When the immediate needs of the victims were met, regardless of the condition - especially economic constraints - the federal effort came to an end. Ironton, as quickly as it stabilized and opened for business also found a number of its residents were now homeless. Given the initiative taken on their behalf at the outset, citizens of that city contacted the War Department inquiring about assistance with housing. Lincoln, though sympathetic, asked that "public notification be made in the newspapers of the Associated Press, particularly those that may reach the flooded areas, that he is not authorized by law to use any part of the fund for that purpose." 56 Since he was only "authorized to distribute subsistence, stores, clothing and other personal necessities," he ordered nearby garrisons to forward excess tents to the town for temporary housing. ${ }^{57}$ Such was the extent of what Lincoln could do for the newly homeless of Ironton.

The government of Illinois encountered a similar problem. Its legislature authorized $\$ 80,000$ in relief funds earmarked for specific counties based on expected need. Gallatin County fared better than predicted, and found themselves holding approximately $\$ 10,000$ more than needed. Nearby Springfield, out of relief funds and desperate for assistance, asked for a transfer of the excess. But without an act of the part-

55 “The Floods," St. Louis Globe-Democrat (St. Louis, MO), Mar. 31, 1884.

56 “The Floods," St. Louis Globe-Democrat (St. Louis, MO), Feb. 21, 1884.

${ }^{57}$ Ibid. 
time legislature reallocation would be illegal. In the meantime, Springfield needed help and none was coming in reasonable time from the state government. ${ }^{58}$

Even when government acted quickly and efficiently, reliance on local actors placed operations in precarious positions. In Helena, Arkansas for example, cries of oversupply were heard loudly. A local judge, entrusted to distribute rations, encountered accusations that he allocated supplies unevenly, benefiting primarily his friends and relatives, and the African American population in the area. These frustrations were dismissed by federal authorities as the selfish concerns of "disgruntled storekeepers whose business of supplying negroes with the necessaries of life had been somewhat interfered with." ${ }^{\circ 9}$ While federal relief operations regularly received criticism - these seemed to grow exponentially whenever black Americans received aid - space existed for legitime criticism of the federal effort. ${ }^{60}$ While government could move quickly, and generally worked efficiently, its lack of flexibility prevented aid from always arriving where it was needed, when it was needed. Here entered the genius of the relief system devised by Barton - the Red Cross would fill the gap between the asymmetry of information that existed between decentralized local fundraising on behalf of natural disaster victims and the statutory requirements of official government recovery missions. The flood of 1884 is where the outline of the system that developed over the following fifteen years first appeared.

58 “Relief Measure," St. Louis Globe-Democrat (St. Louis, MO), Feb. 24, 1884. 59 "Supplies for Flood Sufferers," St. Louis Globe-Democrat (St. Louis, MO), May 8, 1884.

${ }^{60}$ A point which will be visited in more depth when our attention turns back to Arkansas in the Arkansas Drought chapter of this project. 
When it became clear that a crisis was unfolding in the Ohio River Valley, Barton revealed that she, Hubbel, and a staff of approximately fifteen would be undertaking relief efforts personally. ${ }^{61}$ Within a day, notice of her plans were reprinted in a number of American newspapers - such was her cultural celebrity. Prior to leaving for the scene of the unfolding disaster, Barton put into motion the expanded network of local chapters she created in the three years following the Michigan forest fires. Now numbered over sixty, the secretaries of locals went to work raising funds and collecting needed goods. ${ }^{62}$ The St. Louis Red Cross began their effort two days later. ${ }^{63}$ The Cincinnati chapter reported progress two days after that. ${ }^{64}$ The following day Barton reported to the press that more than $\$ 4,000$ came from the chapter in Chicago, while the chapter in New Orleans forwarded around $\$ 7,000 .{ }^{65}$ Smaller communities, those without standing Red Cross chapters, even took advantage of the existing Red Cross organization to push their donations into the relief stream. The citizen of Centralia, Missouri for example, raised and forwarded to the Red Cross $\$ 100$ within two weeks of the initial flooding. ${ }^{66}$ And when the victims of the floods still needed relief in early April, Milwaukee undertook a second round of fundraising, pulling together $\$ 383.04$, which instead of independently determining a location for, sent on to Barton personally. ${ }^{67}$ 1884.

61 "Relief for Flood Sufferers," North American (Philadelphia, PA), Feb. 11, 62 "The Relief Organization Called 'The Society of the Red Cross' Which is Now Rendering Good Service," St. Louis Globe-Democrat (St. Louis, MO), Feb. 19, 1884. 63 "Sufferers of the Flood," Galveston Daily News (Galveston, TX), Feb. 13, 1884.

64 “Ready Assistance," Galveston Daily News (Galveston, TX), Feb. 15, 1884. 65 “Aid for the Sufferers," Galveston Daily News (Galveston, TX), Feb. 16, 1884. 66 "The Floods," St. Louis Globe-Democrat (St. Louis, MO), Feb. 23, 1884. 67 “The Work of Relief,” Milwaukee Journal (Milwaukee, WI), Apr. 5, 1884. 
The system devised by Barton alleviated two problems. First, local fundraising and donation collection efforts, even in places without Red Cross chapters, could take advantage of the organization's reach to push funds and good to the people needing support. This required no research, correspondence, or effort on the part of the local committee. Barton ensured the ease of this system by regularly publicizing her location. When first setting out, she announced the Red Cross team would begin in Pittsburgh, Pennsylvania, travel down the Ohio to survey the destruction and plan the best way to leverage relief. In the meantime, Barton announced their headquarters was to be based in Cincinnati, Ohio, and donations could be sent there. By the time the relief team arrived, with a plan for distributing resources already in hand, cash and goods awaited them at the Cincinnati post office. ${ }^{68}$ When their operations moved to the Mississippi, similar notices of their movements, and more importantly where to send funds and collected items, was broadcast widely.

Seeing the federal government's response to the crisis in action as she travelled down the Ohio, Barton determined the best plan of action was to replicate the methodology. Once arriving in Cincinnati the Red Cross chartered a steamer, loaded it with goods, and returned to the surveyed communities. This is not to say, however, that the Red Cross served the same purpose, or operated in exactly the same way as the federal government. To the contrary, part of what brought value to the Red Cross' system was that unlike the government response, they took steps to protect the investment of donors by deterring fraud. In a letter to the mayor of Milwaukee, who transmitted to

68 "Relief for the Flood Sufferers," North American (Philadelphia, PA), Feb. 11, 1884, and "The Flooded Districts," Bangor Daily Whig and Courier, (Bangor, ME), Feb. $26,1884$. 
Barton funds collected in the city for a second wave of relief, the President of the Red Cross made their efforts distinct from the government. "We have twice visited every city, town and hamlet on both sides of the river the entire distanced traveled - met the people, landed and personally inspected every point for ourselves." 69 In doing so, they determined "the condition of the people in the places where they stay, and left clothing, bedding, fuel and money as required by the necessities presented." ${ }^{\prime 70}$ When asked directly by the press as to how the Red Cross operates, Barton replied, "we shall not interfere with the operations of the Government, for while they distribute generally, we shall endeavor to furnish relief in particular cases." ${ }^{\text {71 }}$ Understanding that trust was central to the Red Cross' ability to function effectively into the future, Barton made the case even more clearly when she commented that they "have worked hard, and have endeavored...to render impossible any fraud upon our charity. We have not awaited the destitute to visit us," but instead landed in locations along the river, "where we thought aid was needed, and quietly sought out the cases needing attention." 72 Even the type of aid provided proved a shift from the governments approach.

When the federal government sent steamers along the river to provide relief, their mission focused on the immediate needs of the victims. This largely boiled down to rations and clothing. Even addressing the significant population made homeless by the floods was impossible by statute. The Red Cross steamers plying the flooded rivers carried rations and clothing, but more importantly, they also distributed the funds and

69 “The Work of Relief,” Milwaukee Journal (Milwaukee, WI), Apr. 5, 1884. 70 Ibid.

71 “The Red Cross Relief Boat," St. Louis Globe-Democrat (St. Louis, MO), Apr. 4, 1884.

72 “The Red Cross,” St. Louis Globe-Democrat (St. Louis, MO), Mar. 14, 1884. 
goods that would allow for victims to return to economic independence. When the relief mission landed in Evansville, Indiana not only did it carry food and warm clothing, but also "household furniture, kitchen and cooking utensils, farming implements, harness, plows, scythes, hoes, lumber, nails, stoves."73 As would be true during the years of Barton's leadership of the Red Cross, relief did not just mean immediate relief. It meant a return to normal. And normal meant a functional household, capable of reentering the market economy. ${ }^{74}$

It would be a mistake, however, to assume that the Red Cross functioning as an ancillary of the market economy meant that by default it reflected the emerging corporate culture of the market economy. While local chapters were chartered, a small army of volunteers stood at the ready, and the organization brought succor to thousands, the Red Cross was not yet a nonprofit corporation. In reality, it was little more than Clara Barton. In a letter to her hometown of Worchester, Massachusetts, which at that point lacked a local chapter, Barton made clear how the organization functioned. "The floods have never been so bad," she reported to her former neighbors, "I have decided to make Cincinnati a Red Cross headquarters for supplies and remittances...I have accordingly this morning notified all our societies of the Red Cross to send me there" the cash and goods collected on behalf of the victims. ${ }^{75}$ After inviting Worchester to participate in the effort, by sending their donations directly to her, she reflected on her experience with the organization. "It seems to me very much like the old days of the war, this placing myself

\footnotetext{
73 “Flood Relief Completed," Milwaukee Daily Sentinel (Milwaukee, WI), May $29,1884$.

${ }^{74}$ Dulles, 28.

${ }^{75}$ Ibid.
} 
once more at the field, for service. I think I can do better work, however, than I did then." ${ }^{" 76}$ It is clear that the organization lacked the culture or systems to operate without the leadership of Barton. In the short-term, her presence and reputation allowed the organization to alleviate much suffering. In the long-term however, such an important and impactful mission on the vision of one person created ripe conditions for conflict.

In 1887, as Texas experienced a severe drought, organizational discord remained fifteen years in the future. But there does seem to have been a shift in the way in which the press spoke of the Red Cross president. It is undeniable that her gender played a role in the way in which her actions, and the organization she led, were interpreted by reporters. Common were descriptions of the woman which discussed her physical features as much as her impressive personal history. "She is of slight nature, with kindly, mobile features beaming with intelligence and showing great strength of character, has large, clear grayish brown eyes that are a beautiful index to her great soul," is how one such journalist captured her essence. ${ }^{77}$ Other journalists tended to follow the same approach in reporting on her, always emphasizing the upright propriety of her femininity. But there was also an undeniable power to her presence.

Such was Barton's respectability, and influence that when it was clear that Texans lacked the ability to manage the drought on their own, she was the person to turn to for 26, 1884.

76 “The Flooded Districts," Bangor Daily Whig and Courier (Bangor, ME), Feb.

77 “Miss Clara Barton,” Galveston Daily News (Galveston, TX), Feb. 12, 1887. 
help. Reverend John Brown, the head of the relief effort composed of the twenty-one counties impacted, knew as much. "He would not have called on the Red Cross Society, but for the slow movement of the State of Texas in affording relief." ${ }^{178}$ Brown was beside himself, that even after the executives of the thirsty counties made it clear, using data, that they were in dire need the nation failed to come to their aid. For that matter, the state government also seemed unwilling to address their needs. "While the hand of the charitable is withheld, says the reverend gentleman, the people are at starvation's door. He left for home today, and said unless the Red Cross came at once there was no hope except in Providence." 79 By the following day Barton was meeting face to face with Brown, investigating the conditions for herself. ${ }^{80}$

Barton found that Stephens county, a rural county approximately 130 miles west of Dallas, represented the norm among the impacted communities: " 1500 people...suffering from want of the actual necessities of life." ${ }^{" 81}$ She relayed to the press "that the only question now in consideration is the most practicable and effective way to find relief for these people, which she will shortly give the state of Texas." ${ }^{\prime 2}$ With her extensive experience of disaster management, Barton was able to speak from a place of authority unlike any other person in the nation. As for the Red Cross' involvement in the actual relief efforts, "she says she will give the state a chance to help its citizens, which if it will not do, she will then call forth the inexhaustible aid of the renowned Red Cross 25, 1887.

78 “Starving People in Texas," St. Louis Globe-Democrat (St. Louis, MO), Jan.

${ }^{79}$ Ibid.

80 "Red Cross Aid to Drought Sufferers," St. Louis Globe-Democrat (St. Louis, MO), Jan 27, 1887.

81 “A Mission of Mercy," Galveston Daily News (Galveston, TX), Feb. 2, 1887.

${ }^{82}$ Ibid. 
Society. ${ }^{\prime 83}$ But that call to engage the local charters of the Red Cross in a national relief effort proved unnecessary. With Barton on the scene, the legislature was finally shamed into acting and appropriated $\$ 100,000$. Viewing these funds as enough to meet the immediate needs of the drought victims, her only remaining concern was providing seed for the upcoming planting season - again, the Red Cross prioritized a return to economic normalcy as much as meeting the need for food and clothing - and after working out plans with local relief committees felt confident that the Red Cross was unneeded. ${ }^{84}$ As one reporter commented, "for nearly two weeks she has been patiently bringing to bear on the matter she had in hand all the great power of her discriminating and penetrating intellect." ${ }^{\$ 5}$ Declaring the matter manageable by local authorities, she made a $\$ 20$ personal donation, and hopped a train back to Washington, DC. In this case Barton may have done more for her reputation by not launching a nationwide relief effort. It demonstrated the measured nature of Barton's, and by default the Red Cross', response to crisis.

But 1887 was to be a busy year for Barton as the fall brought the international gathering of national Red Cross organizations. While it was a largely nuts and bolts discussion of how the organizations would support the injured and infirm in the event of international war - a situation largely avoided by the United States and therefore of limited immediate concern - the press from America focused mostly on Barton herself. A journalist noted that "in the midst of this assemblage of stately, gray-haired men,

83 Ibid.

84 "Miss Clara Barton has been Visiting the Drought Districts of Texas," Rocky Mountain News (Denver, CO), Feb. 23, 1887.

85 "Miss Clara Barton," Galveston Daily News (Galveston, TX), Feb. 12, 1887. 
glittering with military decorations of national honors, won and conferred, sat this one woman." The author found her "calm, thoughtful, self-possessed, recognized as possessing every right and privilege belonging to any member of the conference."${ }^{\$ 86}$ Recognizing the historic nature of her feminine presence, the author continued:

"not merely permitted to be there, but there by the sovereign right of nations; not merely allowed to sit there by the courtesy accorded to a lady, but by the right due to a nation's representative; her vote not merely accepted as a matter of form, but expected and watched for; grave questions referred to her as the representative of a great nation; and all deference paid to her judgement; her demeanor so unobtrusive, her actions so wise, that it could not otherwise than reflect merited credit upon her and her country." 87

Certainly this writer celebrated her presence at this conference while acknowledging a certain unlikeliness to a nation being represented at an international conference by a woman. As the Red Cross grew, in prominence, importance, power, and influence, the sex of the organization's leader also grew in importance. Eventually it led some to question the wisdom of a woman, even one as competent and exceptional as Clara Barton, sitting in such a position of prestige.

86 “The Red Cross," Congregationalist (Boston, MA), Nov. 10, 1887.

${ }^{87}$ Ibid. 
Two years later, when a reservoir outside of Johnstown, Pennsylvania burst open washing the town away with it, something else also changed. Not only were observers of the Red Cross starting to notice that Clara Barton was, in fact, female, but the federal government realized that she knew much more about relief operations than they did. When word of the devastation made its way to Red Cross headquarters, Barton and her team jumped into action, traveling immediately to the site of the disaster. But on this trip, rather than creating a relief effort that served as an auxiliary of the government (federal or local) operation, she was hailed by the commander of the garrison dispatched to lead the effort. He thanked her for coming and consulted her as to how they should proceed. As a newspaper report related the scene:

"experience in the Michigan fires of '81, the overflow of the Mississippi for a thousand mile in '82, the great Ohio floods of '84, the Gulf cyclone the same year, the Charleston earthquake, the Texas drought of '86, the Mount Vernon cyclone and the Jacksonville yellow fever pestilence have made Miss Barton familiar with scenes like this and she knows exactly how to deal with them." 88

Not only did her experience render Barton the logical choice to lead the recovery, but her femininity in the writer's estimation gave her an advantage over men. "The Red Cross made it a point to visit houses, and having a woman with a heart that stirs in sympathy for everyone in misfortune, it is able to reach many deserving cases that otherwise would not

88 “Clara Barton at Johnstown,” Daily Inter Ocean (Chicago, IL), Jun. 23, 1889. 
be heard of." ${ }^{89}$ If her gender created advantages in the work, the federal government was more than happy to make us of them - the relief effort needed some help.

The failure of the reservoir on June $1^{\text {st }}, 1889$ resulted in an outpouring of donations. That day the people of Pittsburgh raised more than $\$ 55,000 .{ }^{90}$ By the $6^{\text {th }}$ Philadelphia collected more than $\$ 500,000$, Washington, DC raised $\$ 25,000$, while Dayton, Ohio sent $\$ 4,000 .{ }^{91}$ On the $8^{\text {th }}$, it was reported that San Francisco collected $\$ 58,000$, New York raised more than $\$ 325,00$, Boston donated $\$ 100,000$, Auburn, Alabama mailed a check for $\$ 200$, even Dublin, Ireland sent the victims more than $\$ 1,000 .{ }^{92}$ When the Governor of Pennsylvania, James A. Beaver, finally made his way to Johnstown on the $11^{\text {th }}$ - quite late in the estimation of more than a few reporters - the city was awash in water while he was awash in cash. In reflecting on the overwhelming number of bodies floating around the water, the governor contemplated the donations, commenting that "the funds which have come into my hands in such large amounts and from so many quarters outside of the state, and which have been imposed upon me," perhaps finding them more a burden than relief, "mean a sacred trust, and will be expended wholly and absolutely for the benefit of individual sufferers." ${ }^{93}$ Undoubtedly, Gov. Beaver was hoping to stave off uncomfortable questions from outside the state. Especially since red flags were already being raised within Pennsylvania.

The flooding produced a serious question regarding the role of government in contrast to the obligation of funds donated for public relief. Without funds set aside for

\footnotetext{
89 Ibid.

90 "A Valley of Death," Milwaukee Journal (Milwaukee, WI), Jun. 1, 1889.

91 "Above the Gloom," Milwaukee Daily Sentinel (Milwaukee, WI), Jun. 6, 1889.

92 “A Ghastly Find," Los Angeles Times (Los Angeles, CA), Jun. 9, 1889.

93 "The Great Flood," Weekly Register-Call (Black Hawk, CO), Jun. 14, 1889.
} 
disaster relief, and like so many states then as now, Pennsylvanian's part-time legislature was not set to meet for months, the governor was desperate to secure cash. The only option left to him was to personally guarantee that funds lent to the state, similar in function to a bond, would be paid back. Having to move prior to the legislature authorizing relief measures, left this strictly a personal guarantee; Beaver was on the hook for the cash, and coming it an estimated $\$ 1,000,000$ he was left exposed financially. He was able to find 200 wealthy Pennsylvanians in Pittsburgh willing to offer up the funds, but this led to a question concerning the funds already collected in Pittsburgh as well as the rest of the state. From the perspective of the Pittsburgh financiers and philanthropist, the clearing of bodies and debris, and the rebuilding of the city, for which the million dollars was requested, was the clear responsibility of government. Relief of the suffering, however, rested with the community. So great was the concern that funds sent for relief would be used for public services - and by that, relieve the governor of some of the personal financial responsibility of the effort - that the city of Pittsburgh refused to forward anymore relief funds until guarantees were received.$^{94}$ In the meantime, doctors on site began to worry about the public health implications of corpses piling up in waterways.

The arrival of Barton and the Red Cross freed the army officers sent to alleviate the town, as well as the laborers assembled by the state government, to work on restoring public health, clearing debris, and rebuilding infrastructure. Relief of suffering, the Red Cross' specialty, became primarily its domain. This reintroduced the foundations of the associational state, at least in mitigating disasters. The first step as in previous disasters,

${ }^{94}$ Ibid. 
was to initiate the nationwide network of Red Cross chapters. Donations of cash and goods began pouring in, this time only requiring a call to action. The chapters understood that their collections were to be sent directly to Barton in the field, as evidenced by the simplicity of her instructions: "We start for Johnstown tonight. Immediately aid should be rendered. Would you like to help?" 95 In quarters, nickels, dollars, and five dollar gifts, all of which were acknowledged in the local newspaper, the Milwaukee chapter collected around $\$ 40 .{ }^{96}$ When specific directions as to what to do after the initial wave of donations passed, chapters determined to continue raising money until told otherwise. ${ }^{97}$

Some chapters received specific instructions from Barton. The Washington, DC branch of the organization was asked to gather, in addition to cash, three hospital tents, twenty-five cots, and all needed supplies; essentially a functioning field hospital. She also requested, with an eye on next steps, "bedding, groceries, provisions and household articles. Clothing is in good supply" and therefore not needed. ${ }^{98}$ The federal government began its response with a significant store of clothing, creating an ad hoc commissary department for the victims. When Barton arrived on the scene the government transferred that responsibility and inventory to the Red Cross. ${ }^{99}$ The federal government, at Barton's request, took on responsibility for transporting stores and personnel, allowing the organization to concentrate efforts on the relief operation and largely take for granted

95 “To Send Relief,” Milwaukee Daily Sentinel (Milwaukee, WI), Jun. 4, 1889. ${ }^{96}$ Ibid.

97 “Johnstown Contributions,” Milwaukee Daily Sentinel (Milwaukee, WI), Jun. $15,1889$.

98 “Purification by Fire," Wisconsin State Register (Portage, WI), Jun. 15, 1889.

99 "Suffering at Johnstown,” Boston Daily Advertiser (Boston, MA), Oct. 7, 1889. 
logistics. ${ }^{100}$ The efficiency of the Red Cross focusing on what it did best, including taking over aspects of the governments mission, and in turn shedding the superfluous, even created the false notion that no further donations were needed. ${ }^{101}$

The relief effort organized by the state government encountered a number of challenges, legal and organizational, forcing the Red Cross to undertake more of the operation. Of particular concern to Gov. Beaver became addressing economic recovery once issues of food, clothing, and shelter were overcome. On June $14^{\text {th }}$, just two weeks into the recovery, Beaver issued a proclamation to the people of Pennsylvania "in which he directs attention to the needs of the business men of Johnstown." 102 While he could state that immediate needs were being met, there remained "the restoration of the usual channels of trade and the machinery of supply and demand." ${ }^{103}$ His mitigation effort called for donations to restore the buildings of merchants and producers via temporary measures. The Red Cross, as done previously, felt they had a role to play in restoring the market economy, again, through household production. With other disaster responses under her belt by the time of Johnstown, Barton crafted a plan for addressing those needs. Establishing a warehouse for non-essential goods, she sent her agents into the field, resulting in "a registry of the city, knows the status, or can readily ascertain it, of every family or remnant of one in the town, and just what they are entitled to under the 1889.

100 "Fire Follows the Flood," Wisconsin State Register (Portage, WI), Jun. 29, ${ }^{101}$ Barton, Clara. "More Help Needed," Daily Inter Ocean (Chicago, IL), Jun. 25, 1889.

102 “The Flood Victims," North American (Philadelphia, PA), Jun. 15, 1889. ${ }^{103}$ Ibid. 
regulations that have been made for the distribution of supplies..."104 Those deemed in need by Barton received all of the supplies necessary to restore their home:

"One set of good bedroom furniture, usually of oak; one extension table with six chairs, one mattress, two pillows, four sheets, two pairs of pillow cases, one pair of blankets, one comfort [sic], six towels and tea towels, one dozen plates, three vegetable dishes, one platter, six knives and forks, and one set of mottled granite ware."105

Families also received sewing machines, seed, feed for animals - all the supplies necessary to restart the family financially. Though it took some time, within five months of the disaster, Barton and the Red Cross restored eight hundred family households with this method. Which also meant, in theory, eight hundred families returned to economic independence. ${ }^{106}$

The Red Cross method of relief seemed to reach full stride in response to the Johnstown flood. Given the impact, size, effectiveness, and authority of the organization, combined with the government largely conceding the relief effort to the group, brought into distinct view Barton's gender. While her treatment in the press, from celebrating her selflessness to describing her physical appearance, remained consistent, the Red Cross itself suddenly became gendered. In reporting Barton's arrival in Johnstown one journalist commented she was "known all over the world... and will at once assume charge of the all-female relief corps."107 Perhaps they were unaware that Barton's

104 “Ministering Angel,” Rocky Mountain News (Denver, CO), Oct. 6, 1889. 105 Ibid.

106 Ibid.

107 “Devastation," Atchison Globe (Atchison, KS), Jun. 6, 1889. 
primary deputy, Hubbell, was male, as were a number of the doctors in the field, as well as orderlies. An article in the Daily Inter Ocean muddled the gendered interpretation of the organization further when it provided numbers of specific cases being treated in the Red Cross hospital. The rundown of cases - ten suffering from diphtheria, twenty-five from "nervous prostration;" and two from pneumonia - was provided by a male Red Cross doctor. Yet, the reporter followed this by elaborating on cases not directly related to the flooding, noting that "Sisters of the Red Cross are also taking care of eight cases of tonsillitis." ${ }^{108}$ It would seem that the men involved in the operation were beginning to be excluded from the organization by virtue of their gender. With the organization suddenly taking on a gendered identity, those assumptions - based in Victorian ideals of male and female domains - relegated the Red Cross beyond the ranks of corporatized organizations. Events in the years following demonstrated clearly that the gendering of the Red Cross had little to do with the organization's donors and volunteers, instead everything to do with Clara Barton.

Two years later, when a hurricane took aim at Galveston, Texas, Barton and the Red Cross answered the call. The devastation was horrifying, with large swaths of the city washed out to sea, and more than 10,000 killed. Yet, with a number of disaster responses under their belts, the Red Cross, the federal government, and the local relief committee, followed the same basic outlines from the existing playbook. The hurricane came ashore on September 8, 1900, and by the $9^{\text {th }}$ the governor of Texas issued calls for help, and by the $11^{\text {th }}$ a United States Army detachment stationed in San Antonio arrived

108 “Sickness Prevailing,” Daily Inter Ocean (Chicago, IL), Jun. 9, 1889. 
to coordinate the federal response. ${ }^{109}$ On the $10^{\text {th }}$ Barton telegraphed the governor, "Do you need the Red Cross in Texas? We are ready." ${ }^{110}$ With an adamant yes as the response, on the $11^{\text {th }}$ Barton set the network of Red Cross chapters to work raising funds and collecting goods to be forwarded to the site of the disaster and set out for Galveston. ${ }^{111}$ Though the federal government (via the Army) in theory led the national response, and a local relief committee coordinated by elected officials organized to muster regional efforts, when Barton arrived all deferred to her wisdom. Aside from the normal distribution of rations, clothing, direct financial aid, and eventually the supplies for reigniting participation in the market economy, Barton also led the charge for addressing the widespread homelessness of the city. Pulling together architectural plans overnight, the Red Cross proposed constructing a series of four room cottages to provide emergency housing for the more than 8,000 residents of Galveston and the surrounding area whose homes were destroyed. ${ }^{112}$ Two months later, with the city firmly on the road to recovery, Barton headed back to Washington, DC. ${ }^{113}$ But this would not be a celebratory homecoming.

Unlike any previous relief effort, the Galveston response was plagued with public criticism. After the first month of operation newspapers began printing accusations that

109 “An Appalling Disaster," Grand Forks Daily Herald (Grand Forks, North Dakota), Sept. 11, 1900.

110 "Proffers of Aid for the Stricken City," Age-Herald (Birmingham, AL), Sept. $11,1900$. 1900.

111 "Red Cross Begins Work," New Haven Register (New Haven, CT), Sept. 11, 1900.

112 "Relief Work at Galveston," Times-Picayune (New Orleans, LA), Oct. 7,

113 "Frail and Worn Homeward Bound," Times-Picayune (New Orleans, LA), Nov. 16, 1900. 
money was not being fairly distributed, or simply vanishing from the coffers. ${ }^{114}$ For example, it was reported that a victim of the hurricane applied for $\$ 250$ in aid, but received nothing. Because there was no clear responsibility for the relief effort, criticisms of relief in general fell on the federal government, the local relief committee, and the Red Cross equally. The treasurer of the local relief committee attempted to discredit the story of the unfulfilled $\$ 250$, noting that "no man has a right to $\$ 250$ or any other amount of the fund until the amount is awarded by the proper committee on the basis not of what he lost, but his present needs." 115 The local relief committee suspected that many of these stories, where in fact not victims who did not receive support, but rather "from the gang that has tried to rob the relief fund under false pretenses of loans and need of assistance."116 To deflect further criticism, the local committee turned to the positive remarks of Barton regarding the regional response. ${ }^{117}$ But the Red Cross was under the microscope.

Responding to a series of newspaper articles from Detroit and Chicago papers, Barton acknowledged that the local Red Cross was accused of using donated cash for non-relief expenditures, and that goods sent for the victims were sold by the committee to local retailers, who then resold them at a profit. As done in prior efforts, some goods, especially perishables, were sold at the place of donation rather than transported to Galveston, with those funds then making their way into the relief fund. Those decisions were not just endorsed by Barton but were made at her suggestion. In fact, Barton felt she

114 “Relief Work at Galveston,” Times-Picayune (New Orleans, LA), Oct. 7, 1900 .

115 “Galveston Relief Worse,” Baltimore Sun (Baltimore, MD), Nov. 27, 1900. 116 Ibid.

${ }^{117}$ Ibid. 
could vouch for the local relief committee as she participated in every executive meeting of the group, coordinating the Red Cross response so as not to duplicate effort with the federal or local operation. She was familiar with the financial transactions of the committee and felt she could endorse them as reasonable. Furthermore, anticipating what was quickly becoming an expectation in charitable relief efforts, Barton commented, "as to the caliber, business capacity, unstinted earnest application to the work in hand, and the integrity of the committee, individually and collectively, I have never known their equal." ${ }^{118}$ From her vantage point, the committee was both sympathetic and businesslike, as required by donors. Some newspapers, such as the Philadelphia Inquirer came to the rescue of the relief committee and the Red Cross. Sending a journalist to Galveston to investigate the work directly, the editors declared the relief effort above board. ${ }^{119}$ But a taint would be attached to the effort, and the reputation of the Red Cross lost some of its shine. But this was not the only way in which Barton the paragon started to look fallible. After six weeks of coordinating the disaster response, Barton became quite ill, "the result of overwork. Nervous prostration is the final outcome." ${ }^{120}$ Her aides made a number of public comments, assuring donors that Barton remained in command of the effort, even from her sick bed. "In explaining Miss Barton's condition, Mrs. Ward stated that the patient has been dictating about forty letters a day... and that while physically weak, her mind kept very active, and she wanted to keep on working," in spite of the Red

\footnotetext{
1900. 119 “The Truth About Galveston," Philadelphia Inquirer (Philadelphia, PA), Oct. 11, 1900.

120 "Clara Barton if Very Ill," Wilke-Barre Weekly Times (Wilkes-Barre, PA), Oct. 27, 1900.
}

118 "Relief Work at Galveston," Times-Picayune (New Orleans, LA), Oct. 7 , 
Cross doctors telling her she needed rest. ${ }^{121}$ Unable to leave her car during the train ride back to Washington, DC, her staff made it clear to the press that her departure was a natural outcome of the success of the relief effort, and not related to her illness. ${ }^{122}$ In some reports, they even denied she was sick at all. ${ }^{123}$ Suddenly, building a national relief organization based completely on the leadership of a seventy-nine year old leader presented significant challenges.

Barton would recover. In fact, she lived another twelve active years, passing at ninety. But in 1904 Barton resigned the position as president of the organization, succumbing to a series of conflicts within the Red Cross. While some bristled at her leadership style, or felt that she was too old to continue to lead from the front, the primary problem was the culture of the organization. Recalling that Barton created the Red Cross largely out of thin air, with nothing more than inspiration from the Geneva Convention on which to lay the foundation, it operated without any formal legal recognition for much of its early history. In 1882, the year following the organization's beginning, the United States formally signed the Geneva Convention, which called for each member state to charter an independent branch of the Red Cross. It was not until 1900 that Congress finally recognized Barton's creation as the nation's official Red Cross

121 "Miss Clara Barton Dangerously Ill," Columbus Daily Enquirer (Columbus, Georgia), Oct. 25, 1900.

122 "Frail and Work Homeward Bound, Miss Clara Barton Passes Through New Orleans Again," Times-Picayune (New Orleans, LA), Nov. 16, 1900.

123 "Normal Conditions Are Fast Being Restored in Galveston," Age-Herald (Birmingham, AL), Sept. 20, 1900. 
Society. Once acknowledged by Congress, the Red Cross transformed over night from an independent charity to a quasi-governmental organization answering to the federal government. Congress expected an annual report - leading to the creation of the first in the Red Cross' history in 1901. And the president, as the head of the government, became chair of an advisory board that was truly just advisory. While Congress received an annual report, the president neglected to take advantage of the honorary position provided; until 1903.

When the Red Cross' annual meeting convened on December $9^{\text {th }}, 1902$, some members of the organization were shocked to discover that the meeting was poorly attended. It appeared, at least to a particular faction within the organization the Red Cross' leadership explicitly discouraged attendance. A letter sent to a member in Connecticut explained that rather than make the trip to Washington, DC, "will you kindly sign the inclosed [sic] proxy in blank and send it to Miss Barton by first mail. She is desirous of having some slight changes in the by-laws of the Red Cross," the clerk explained, "and it is necessary that two-thirds of the members should either be present or send proxy. It will be a great favor to her if you will comply with this request." ${ }^{\text {2 }} 24$ Those "slight" changes to the by-laws included making Barton the president of the organization for life, concentrating all power in her hands, and placing as the only check on her authority an executive committee consisting of people she held the power to appoint and remove. Further exacerbating an already tense internal conflict, when the membership were forced to vote on the change without deliberation, seventy-two of the eighty-nine

124 "Memorial of Officers and Members of the American National Red Cross, Relating to Amended By-Laws Recently Adopted at a Meeting of that Organization," 2. 
votes in favor were proxies. ${ }^{125}$ Caught flatfooted, the opposition could not help by feel that the fix was in.

In searching for a strategy to combat what they viewed as unethical and potentially illegal changes to the by-laws, they appealed to the only source of power that could potentially sway the matter: President Theodore Roosevelt. It is not surprising that Roosevelt weighed-in on this organizational squabble since the signers of the letter were notable: Judith Ellen Foster, the first female attorney of Iowa; Bessie Kibbey, international philanthropist; Brainard Warner, banker and real estate developer; Simon Wolf, general consul to Egypt; Mero Tanner, wife of James Tanner, the federal commissioner of pensions; Thomas F. Walsh, owner of the largest gold mine in America; Harriet Blaine Beale, daughter of a former Secretary of State; the presidents eldest sister, Anna Roosevelt Cowles; and John W. Foster, former Secretary of State, to name a few. ${ }^{126}$ As presented to the president, though taking issue with the power grab in general, the primary concern was a lack of organizational controls. Or rather, the lack of a corporate culture. In many ways the system put in place via by-law changes only codified the Red Cross' existing operations. As had happened in every prior disaster relief operation, donations for victims of some terrible fate flowed directly to Barton, and were distributed without the consent of anyone else. Though she worked hard to directly acknowledge every cash donation received, the accounting remained unreliable at best often non-existent if it was received at the site of a disaster. No audits were ever undertaken, and the by-laws, while making clear that the president of the organization

\footnotetext{
125 Ibid., 3.

${ }^{126}$ Ibid., 2.
} 
acted by fiat when mitigating a disaster, made no attempt to account for funds after the fact. Without controls and accountability, it was unlikely that the Red Cross, growing in chapters, members, and donations, would also develop from being an ad hoc relief organization into a truly corporatized nonprofit corporation. As the experience of the Galveston Hurricane demonstrated, when questions of the conduct of the organization were raised, it was impossible to directly counter them since a proper corporate governance did not exist. ${ }^{127}$

Though sympathetic, Roosevelt was unsure of how to respond given that he had "no official connection," with the organization. ${ }^{128}$ Those with access to the president pressed the case, resulting in George Cortelyou, Roosevelts secretary, sending a letter to Barton presenting her with the facts from his perspective. Not only had Roosevelt received a letter from a who's who of Washington, DC philanthropy with concerns about the organization, but the Treasurer of the Red Cross notified him of his resignation "on account of dissatisfaction with what is alleged to be the loose and improper arrangements for securing the needed accountability for and supervision of the disbursement of money furnished in times of exigency." 129 Furthermore, the president received a copy of the amended by-laws, which still included a role for the office and cabinet members on an advisory committee, for which "it is not possible for the President or any members of his Cabinet to serve on such a committee, and the President directs me to request you have it publicly announced" that they would not be serving. ${ }^{130}$

127 Ibid., 4, 6-7.

${ }^{128}$ Ibid., 5.

129 "Letter for the Secretary of the American National Red Cross Transmitting the Report for the Year Ended December 31, 1904," 1.

${ }^{130}$ Ibid., 2. 
Barton immediately responded, assuring Cortelyou that "no use will be made of his name or that of his most honored cabinet," and sharing the history of how a role for the president made it into the by-laws to begin with, a practice predating Roosevelt's administration. ${ }^{131}$ Regardless, Roosevelt was not interested in lending even the appearance of his endorsement to the troubled organization. In response, Barton appealed to Congress, stating that "contribution in money and supplies have been received for the relief of sufferers by the calamities, as shown by several reports, of more than $\$ 1,900,000$, and although the exigencies of the situation rendered the work of distribution one of great difficulty," Barton assured Congress, "it has been done so wisely, prudently, and effectively as not only to accomplish its purpose, but to excite the admiration of all who were personally conversant with it."132 Congress, unsure of what to make of these myriad claims, referred the matter to the Committee on Foreign Affairs for investigation.

The chair of the committee, Senator Redfield Proctor of Vermont, made clear to both factions that the investigation was neither to assign blame nor find wrongdoing, but to establish a way forward for the organization. The opposition aired a number of grievances during the hearing, the crescendo coming when a former aid of Barton's accused her of diverting $\$ 12,000$ from a fundraising campaign to alleviate the famine in Russia to purchase a farm. In reality, the farm was sold to Barton for $\$ 1$ by a supporter of the Red Cross. Though she retained rights to the property, she planned to utilize the land as a long-term supply depot, in which future relief operations could be staged. Multiple witnesses testified as to the arrangement, documentation was produced, including

${ }^{131}$ Ibid.

132 Ibid., 5. 
evidence that the witness previously attempted to blackmail Barton on this topic, yet the slipshod way in which accounting was managed made it hard to dismiss the issue. In the end, Proctor felt that the opportunity for both sides to present their case had simply amplified existing grievances. No report was submitted by the committee. Instead it simply announced that Barton was cleared of all allegations. With her name cleared, public confidence waning, and no hope of leading the Red Cross into the future, Barton was convinced to resign her position. ${ }^{133}$

With Barton out of power, the Red Cross undertook a period of significant reform and put in place a corporate culture of accountability, hierarchy, and a separation between the business leadership of the organization and those managing relief efforts. And thus, a barrier of responsibility between those who raised revenue and those who expended relief funds. Rather than one source of power, the Red Cross become decentralized, with those in leadership exercising roles and responsibilities that served as internal checks and balances. As part of the reforms, the President of the United States was granted the authority to select the overall Chairman of the organization. Roosevelt appointed Secretary of War William Howard Taft to the post. The membership of the organization elected Rear Admiral William K. Van Reypen, former surgeon general, as the President of the organization, leaving the business operations and strategic leadership of the Red Cross, for the first time, in the hands of a man. Functional leadership of the organization, however, fell to Mabel T. Boardman, a longtime member and critic of Barton. It is

${ }^{133}$ Dulles, 73-75. 
Boardman who is widely credited with transforming the Red Cross from a woman-led charity to a male-led one modern nonprofit corporation. ${ }^{134}$

Boardman many expected to fight to succeed Barton. Instead she pushed forward the former surgeon general. They had long been friends, and had a strong working relationship, and she assumed her role would be significant even with him in the president's seat. When asked why she stepped aside, Boardman informed a confidante, "we can do nothing about getting to work toward the raising of the Red Cross fund," a dependable reserve fund being the highest priority, "until we have some reliable, wellknown man as active president, for the persons on whom we must depend for a fund will not contribute a penny under present conditions," that is, female leadership. ${ }^{135}$ To another correspondent, she declared, "I shall never accept the Chairmanship. The Chairman must always be a man." ${ }^{136}$ As Mrs. Boardman recognized, a nonprofit corporation, to attract donors and build public confidence, required a corporate culture; and that required male leadership.

134 Ibid.

135 "Letter from the Secretary of the American National Red Cross," 16. ${ }^{136}$ Dulles, 69. 


\section{Chapter 8}

The Red Cross \& YMCA Goes to War

During the long summer of 1918, Private Newton Balog, then serving in a water tanker unit assigned to the American Expeditionary Force in France, regularly wrote to his brother stationed in the United States. Among the normal talk of missing loved ones, close calls in combat, and humorous anecdotes, Balog included scenes of the nightlife. Largely operating from Paris, Balog relayed to his kin that he had "... been to some dances in town at the Soldier and Sailors Dance hall. Believe me you have fun especially the one that can dance. I am glad I know how. It don't cost us nothing but care fare and we meet some swell people too."1 Movies were also available, but Balog preferred to visit the YMCA for regular entertainment instead. "They have dances there two nights a week and a big swimming pool. That I like, good swimming."2 In Paris, this was not the only amusement available to the troops. "The hangouts are the Y.M.C.A. the [Knights of Columbus] and Red Cross. They give pretty good shows. They have shows that run for a week and we have seen them once, then we go to a French show." 3 Paul Andrews, a private in the $308^{\text {th }}$ Infantry, informed his aunt and uncle back home of similar experiences. Writing on YMCA letterhead, sent in a Red Cross envelope, Andrews regaled his family with tales of entertainment near the front. While he found camp life enjoyable enough - he thoroughly enjoyed being in the open air - "one thing worth

\footnotetext{
${ }^{1}$ Newton Balog, "Letter to Brother, July 4, 1918," Seven Letters Written By Newton Balog, 4.

${ }^{2}$ Ibid.

${ }^{3}$ Newton Balog, "Letter to Father, October 15, 1918," Seven Letters Written By Newton Balog, 6
} 
mentioning was the splendid treatment that we received from the Red Cross and the Y.M.C.A. We had to stop as [sic] several places for sometimes half a day, or over night [sic], before we could make train connections," but at least with organized hospitality, "we could always get something to eat and drink at one place." 4 The Red Cross facilities were welcomed as he looked forward to their "real beds," as were the YMCA operated post exchanges, though he was often disappointed "...they have very little stuff to sell, and are out of cigarettes most of the time." 5 The experiences of Balog and Andrews are infinitesimally small samples of the soldiers' remembrances of the impact of the Red Cross, the YMCA, and other organizations on their war experience.

So ingrained were these organizations in the war effort that a dentist in the employ of the YMCA, Charles Glen Irons of Chicago, Illinois, found himself aboard a troop train making its way from Siberia to Western Russia. With transportation arranged by the United States government to move Ukrainian troops previously evacuated from their fight against the Communist Revolution back to the front, they now found themselves served by the full apparatus of the American military, including Red Cross and YMCA detachments. ${ }^{6}$ Irons reported to his wife that he travelled on "... a special train of fifteen cars, a freight train of course, but my car is a Pullman De Luxe, I sure did have it made as comfortable as it was possible. About the only thing I really lack..." he boasted, “...is an up to date bathroom. My electric light system is working fine, my

\footnotetext{
${ }^{4}$ Paul F. Andrews, "Letter to Uncle Oscar, July 5, 1918," Letters Written by Paul F. Andrews, 5.

${ }^{5}$ Ibid., and Paul F. Andrews, "Letter to Uncle Oscar, July 18, 1918, Letters Written by Paul F. Andrews, 6.

${ }^{6}$ Charles Glen Irons, Letters Written by Dr. Charles Glen Irons to His Wife and Daughter in Chicago, Illinois. In order to piece together Irons story, the entirety of his letter collection is required.
} 
dental office is as good as I had back home, with the addition of an X-Ray machine and minus a switchboard."7 As was often the case, and Irons' experience echoes, it was difficult to where the official war effort ended and the philanthropic war effort began. That a dentist employed by the YMCA travelled the length of Russia with a band of Ukrainian rebels, in one of the more bizarre events of the Great War, only makes sense in the context of the Associational State.

At the outset of the conflict it was clear that the Great War required a different approach from prior conflicts; an approach historians have referred to as 'total war,' in which the economy and society are temporarily organized to prioritize the needs of the war effort above all else. Between the need to ramp up the war material required by American forces, not to mention meeting the shortage of supplies among allies and food needs of civilians, meeting the challenge of the Great War was a monumental task. One that required a novel approach to manufacturing, logistics, and coordination.

Into this breach stepped America's fully developed corporate culture. Sold to President Woodrow Wilson as the 'American System,' the proposal for how to manage the war effort came from corporate leaders who professed that coordination and cooperation between government and private industry were long lasting American traditions. Innovations in organizing production quickly followed. The War Industries Board, a cooperative body with representatives from American industry, government, and suppliers, created a system of price controls and order prioritization that ensured factories producing supplies for the war effort avoided shortages of raw materials. The Railroads

${ }^{7}$ Charles Glen Irons, “Dr. Charles Irons to Family, Oct. 18, 1918," Letters Written by Dr. Charles Glen Irons to His Wife and Daughter in Chicago, Illinois, 6. 
War Board, pulling constituent members from industry and government, was tasked with reordering railway traffic to prioritize war production needs before standard commercial traffic. The War Labor Policies Board, bringing together representatives from essential industries, labor unions, and the federal government worked to mitigate disputes between manufacturing corporations and their employees. The Food Administration, perhaps the most impactful of all of these new agencies, under the leadership of Herbert Hoover, created a forum for farmers, distributors, government, and public relations professionals to meet and execute policies (and the connected advertising campaigns) to help producers increase their yields, and encourage Americans to conserve the nation's bounty. It is the Food Administration that invented, and marketed, 'Wheatless Mondays,' 'Meatless Tuesdays,' and 'Porkless Thursdays' - a key, if unheralded, act of assistance to the larger war effort. 8

These efforts, taken in connection with countless others, may not have produced economic efficiency, financial fairness, or completely avoided shortages, but it did cobble together an alliance between government and private industry capable of prosecuting the nation's first total war. While the heavy lifting of military production and feeding America fell to corporations and smaller economic actors, emerging nonprofit corporations played a substantial role as well. By the end of American neutrality, more than 130 organizations were directly involved in easing suffering among the belligerent nations. ${ }^{9}$ When war was declared, organizations ramped up support to include the war

${ }^{8}$ Ellis W. Hawley, The Great War and the Search for a Modern Order: A History of the American People and Their Institutions, 1917-1933 (Long Grove, Il: Waveland Press, Inc., 1992), 16-22.

${ }^{9}$ Robert H. Bremner, American Philanthropy (University of Chicago Press: Chicago, Il, 1988), 122. 
effort. The YMCA, Knights of Columbus, Jewish Welfare Board, and the Young Women's Christian Association all stepped in to improve camp life for the soldiers. ${ }^{10}$ The American Red Cross and Young Men's Christian Association in particular demonstrate the role of corporatized charity in this governing arrangement. Organizations such as these - in pursuit of a bureaucratized structure reflective of the for-profit world, combined with a management culture armed with policies, procedures, and an ethos of efficiency - emerged as key constituents in the alliance tasked with managing the war effort. In fact, even with the synergy of these organization's missions and the nation's need, inclusion in the Associational State was predicated on their corporate culture. As the Civil War demonstrated, there was no place of significance within the governmentbusiness-association alliance for amateurish charities. Only truly corporatized nonprofit corporations demonstrated the management and efficiency to assist. For both organizations, a position of prominence within the Associational State's war effort represented a coming of age - each recognized as celebrating a corporate organizational culture. Scholars have tended to overlook the contribution of these nonprofit corporations, even while acknowledging it peripherally. Yet, as the Red Cross and YMCA experience in the war demonstrates, the American effort would have been much less manageable without their programming, fundraising, and zeal for enhancing their corporate cultures.

In 1913, on the precipice of the first World War, the American Red Cross, for all of the machinations to remove female leadership and establish a more corporate culture,

${ }^{10}$ Ibid., 125. 
remained much as it had under Clara Barton. The organization still responded to domestic disasters by initiating nation-wide fundraising and rushing relief workers to the scene. The administrative bureaucracy remained largely informal, rendering it capable of flexibly responding to specific needs. ${ }^{11}$ As the rest of the world predicted a major international conflict, the American Red Cross remained as naive as the nation it served. The closest thing to a substantive activity reported under the heading of 'War Relief' in 1913 was providing medical services to the veterans gathering at the site of the Battle of Gettysburg for the $50^{\text {th }}$ anniversary. In February and March the organization's War Relief Board met several times with the War and Navy Departments to plan for the integration of Red Cross relief in future engagements, but found it "regrettable that so little has been done toward obtaining the model organization... which it was the sense of that committee should be established." 12 Yet, retaining the flexibility of the Barton era proved a smart decision; the American Red Cross was about to find itself incredibly flat footed.

With conflict unavoidable by late July, 1914, the American Red Cross commenced war relief efforts, which generally focused on addressing the unmet medical needs of soldiers and civilians alike. Beginning with a meeting of the International Relief and War Relief committees, the American Red Cross, representing a still neutral nation, made offers to provide supplies and staff to all belligerent nations. All accepted the offer, except Belgium, which requested only supplies. With transportation between North America and Europe precarious, the organization requested the federal government take responsibility for moving supplies and personnel. Though the Wilson administration

${ }^{11}$ George W. Davis, Ninth Annual Report of the American National Red Cross, American National Red Cross: Washington, DC, Jun. 10, 1914, 5-9.

12 Ibid., 245-26. 
supported a role for the organization in relieving war related suffering, the government's limited transportation capabilities were already strained with rescuing American expatriates seeking escape for the warzone. Instead, recognizing the officially sectioned nature of their mission - and anticipating the associational state premise behind the coming war effort - the national government instead instructed the Red Cross to lease steamers, but regardless of their nation of origin, were allowed to fly the American Flag and Red Cross banner. This combination kept the ships theoretically safe from accidental attack mid voyage. ${ }^{13}$

The Hamburg-American line offered the first of several Red Cross chartered steamers for $\$ 1$, with an all-volunteer crew of retired American naval officers. Carrying 156 medical personnel, a large cache of medical equipment and supplies, at a cost of $\$ 1,200$ per staff person in salary, supplies, and transportation costs, the ship landed at Falmouth, England. From there teams of doctors, surgeons, and nurses made their way for various points within Europe. A smaller detachment of fifteen staff destined for Serbia travelled separately, making their way to Greece first, as getting in and out of Serbia, where active fighting was intense, proved a significant challenge. By the end of 1914, the Red Cross provided the belligerent nations with an array of medical supplies, free of cost: 432,600 pounds of absorbent cotton; 87,000 pounds of nonabsorbent cotton; 579,000 yards of gauze; more than 640,000 bandages; 20 complete surgical sets meeting the standards of the US Army; 9,000 pounds of chloroform; 15,000 typhoid treatments; 7,000 tetanus treatments; and an unknown, though large, number of rubber gloves,

${ }^{13}$ George W. Davis, Tenth Annual Report of the American National Red Cross, American National Red Cross: Washington, DC, Mar. 4, 1915, 15-16. 
thermometers, syringes, alcohol, disinfectants, stretchers, hospital garments, sheets, pillowcases, blankets, and towels. ${ }^{14}$ Essentially, each team transported to Europe carried a full field hospital in their luggage.

The work of a highly managed industrial war effort remained three years off, but the outlines of the cooperation and coordination that defined America's response was already present. Over the course of 1914, the American Red Cross responded to requests for financial assistance from European Red Cross societies by raising and transmitting more than $\$ 170,000$. Every cent disbursed, regardless of from where it was raised in the United States, or the national Red Cross receiving it, was transferred either by the United States Department of State, or the American Express Co., sometimes both working in conjunction, all without any administrative overhead. ${ }^{15}$ Throughout the war, in the same way that the national war effort was built on the support of private industry and nonprofit corporations, the Red Cross' operations counted on private industry and government support for effectiveness.

Even though the foundation of the Red Cross' response was clear, the path to America's eventual direct involvement and the role the organization would play remained muddy. Discussions concerning Red Cross support to the Army and the Navy continued to produce few results. As a stop-gap, working with State and County medical organizations, the national Red Cross initiated 325 local committees for 'Red Cross medical work.' Hoping for similar creation numbers in 1915, the intention of this work was to provide a springboard for medical support in the event the United States entered
${ }^{14}$ Ibid., 16-17.
${ }^{15}$ Ibid., 17. 
the war. Their specific goal, of organizing standby field hospitals and relief units, "has made little progress" ${ }^{16}$ People came forward volunteering to help organize local units for deployment alongside of the military, but "the individuals composing the groups have not been made up to the standard acceptable to the [Red Cross] bureau of medical services. ${ }^{17}$ Finding a solution to this problem became central to an effective Red Cross response to a theoretically, but increasingly likely, foreign war. But that would have to wait for the future; 1916 brought the organization little downtime to organize a thorough domestic response.

By the middle of 1916 Red Cross volunteers were delivering aid and relief to wounded soldiers and impacted civilians throughout the belligerent nations: Vienna, Austria; La Panne, Belgium; South Devon, England; Cosel, Germany; Gleiwitz, Germany (modern day Poland); Pau, France; Yvetot, France; Budapest, Hungary; Kiev, Russia; Gevgelija, Serbia (modern day North Macedonia); Nis, Serbia; and Valjevo, Serbia. ${ }^{18}$ Between these twelve American Red Cross sites, seventy five surgeons and 255 nurses, representing all fifty states were estimated to have aided more than 30,000 wounded and sick soldier and noncombatants. ${ }^{19}$ Additionally, continuing the effort of the previous year, the organization provided volunteer medical personnel with all needed supplies and payment for their services. Drawing from the incredible industrial might of the United States, the American Red Cross took on responsibility for fulfilling orders for medical

${ }^{16}$ Ibid.

17 Ibid., 17.

${ }^{18}$ Arthur Murray, Eleventh Annual Report of the American National Red Cross, American National Red Cross: Washington, DC, Jul. 27, 1916, 10-25. Nowhere in the report is the location of each medical team provided. This list was accumulated by combing the information provided about each individual mission.

19 Ibid., 25. 
supplies to the belligerent nations, worth approximately $\$ 1.25$ million. To encourage the strained Red Cross societies of the nations at war to make their needs known, the organization fulfilled these requests without passing on transportation costs to their peers. ${ }^{20}$ But by late October, 1916, everything stopped.

The explanation provided for the American Red Cross' decision to end their field hospitals and in-field medical teams appears logical. "As the spring of 1915 advanced it became more and more evident that the amount of funds and other donations being made to the American Red Cross was steadily decreasing." 21 It was assumed this was "due to the great demand made on the people of the United States in their endeavor to relieve distressed conditions in Europe," rendering it necessary to "curtail expenses if any personnel was to be maintained for the succeeding year." 22 After surveying conditions in the medical services of the battling armies, as well as the support provided by other national Red Cross societies, the organization's leadership "felt that as the war has been in progress for nearly a year the sanitary services of the various belligerent countries, as far as personnel was concerned, should be well organized," and with that time to develop a system, "assistance of surgeons and nurses from the American Red Cross was no longer greatly needed." ${ }^{23}$ Supplies would continue to be a problem as manufacturing was adversely impacted especially the more a nation came in contact with the front. August $1^{\text {st }}, 1916$, via the American ambassadors to the nations at war, the Red Cross provided notification that they would be withdrawing medical staff. ${ }^{24}$ The only problem with their
${ }^{20}$ Ibid., 26.
${ }^{21}$ Ibid., 9.
22 Ibid., 9-10.
${ }^{23}$ Ibid., 10.
${ }^{24}$ Ibid. 
plan, came in the assumption that after a year systems would be in place to fill the vacuum.

The story of how the various medical teams in the field disbanded demonstrated this was not the case. When the unit stationed in South Devon, England was disbanded, rather than return to the United States, the majority of the staff transferred to the American Women's War Relief hospital in London. Others joined the Haslar Royal Naval Hospital in Gosport, England. Only six, who transferred to the Red Cross hospital in La Panne, Belgium remained on the organization's payroll. ${ }^{25}$ Most of those stationed in Kiev, Russia joined up with the Russian Red Cross, ultimately taking charge of a hospital in Persia, well behind the lines; a few returned to the United States and left the service of the Red Cross. ${ }^{26}$ These moves relieved the organization of all of their salaries. The team dispatched to Vienna, Austria found the Royal Reserve Hospital completely turned over to them by the Austrian military, where they operated from November $14^{\text {th }}$, 1914 until September $15^{\text {th }}, 1915$. At that time a majority of the physicians and nurses travelled to Berlin, where they joined up with the staffs of the Red Cross detail previously assigned to Budapest and Gleiwitz. At the request of the German government, the remaining staff from these three combined Red Cross units travelled to Russia to provide care to German prisoners of war. Again, the entire staff left the employ of the organization. $^{27}$

Closing up shop in Serbia proved more challenging. Actually, everything in being assigned to Serbia brought obstacles. The team sent to Valjevo found themselves rerouted

\footnotetext{
${ }^{25}$ Ibid., 12-14.

${ }^{26}$ Ibid., 17-19.

27 Ibid., 14-15.
} 
at the request of the government to Belgrade, where they were placed in control of a field hospital already containing patients. From October $1^{\text {st }}$ to December $15^{\text {th }}$ they provided medical services to more than 1,000 wounded soldiers. By December $2^{\text {nd }}$ the Serbians evacuated the city and it was occupied by the Austrians, resulting in a flood of new wounded soldiers. In the early days of the occupation the staff found themselves caring for more than 3,000 patients. When the Serbians reoccupied the city shortly thereafter, the American Red Cross staff were ordered by civil authorities to manage all medical services in the city, which they found included care for those housed in the insane asylum. Even with a staff augmented with Serbian doctors and nurses, the task before the American's was herculean; simply organizing how to feed the 6,000 patients suddenly in their care proved challenging. All of this occurred against the backdrop of a typhoid outbreak which claimed the lives of a number of the Americans stationed in the city. Given the changing military circumstances the Red Cross was forced to maintain this team as evacuation was impossibly in $1915 .{ }^{28}$ The group assigned to Gevgelija discovered even worse conditions - the already occupied hospital assigned to them was actually a tobacco processing factory incapable of reaching medical standards for cleanliness. With more than 1,000 wounded awaiting care, time for sanitation did not exist. As if conditions were not challenging enough, the wells they drew their water from were contaminated by human waste, meals had to be prepared in converted outhouses, there was no laundry facility, nor indoor toilets, the building had a vermin problem, and the patients were covered in lice. So impossible were the conditions in the hospital that the staff began to fall ill. In short order the majority of the American volunteers

${ }^{28}$ Ibid., 19-20. 
contracted typhoid fever. Once recovered, those infected were evacuated back to the United States, and off the Red Cross payroll. The small number who remained healthy were eventually transferred to Belgrade, whereupon they became stuck as well. ${ }^{29}$ Even the group dispatched to Nis, to establish a children's hospital soon found their facility flooded with wounded soldiers and their child patients sent elsewhere. They also found themselves stuck without a safe evacuation path and ended the year still in service to the Red Cross. ${ }^{30}$

As the various experiences of the men and women in the service of the American Red Cross in Europe during the early years of the war demonstrate, the organization's assertion that American medical staff was not needed simply does not meet reality. Those who wanted to remain in service found new employers, often other nation's Red Cross societies. What was correct in the nonprofit corporation's explanation of their withdrawal from the field was an effort to reduce expenses. Even with doctors and nurses remaining in the field elsewhere they did so without drawing an American Red Cross paycheck. While it would be easy to draw the conclusion that these measures were done without regard for the humanitarian implications, inspired only by the bottom line, this is not a far conclusion. The American Red Cross could have required all staff to return to the United States as part of their discharge from service; instead, the number of staff who transferred to other organizations indicates some level of encouragement to remain in the field. Rather than giving up on the Great War the American Red Cross was repositioning to better serve the coming American war effort.

${ }^{29}$ Ibid., 20-23.

${ }^{30}$ Ibid., 24-25. 
For the fiscal year 1916-17, with a significant reduction in medical staff abroad, the Red Cross focused on distributing supplies and reorganizing for the future. Following the system created in the prior fiscal year, the American Red Cross continued to collect funds and via the State Department and American Express Co., transmit cash to relief organizations on the ground. Additionally, they continued to collect donations of medical supplies and transportation to the belligerent nation. Even when challenges arose with moving materials to the Central Power nations the organization remained committed to neutrality and found new routes and secured consent from interfering nations. ${ }^{31}$ For that fiscal year, the American Red Cross collected and distributed approximately $\$ 700,000$ in direct relief funds. They also began acting as agent for relief groups in the United States generally those inspired by ethnic identity - in moving funds from the United States to overseas relief organizations. Jewish relief committees, for example, raised more than $\$ 50,000$ to ease conditions in Poland, which was then transferred to the Red Cross, who undertook to identify appropriate organizations in Poland, to which the cash was transmitted. ${ }^{32}$

With the organization's direct expenses curtailed, and the vast majority of American Red Cross operations in Europe ended, they could turn their attention to the significant challenge ahead: what to do if the United States entered the war? Part of the problem was built-in cultural opposition to the type of coordination that would be needed. The Red Cross itself found that "in our country, although the advantages of centralized control in business matters are generally recognized, and their absolute necessity in

\footnotetext{
${ }^{31}$ Ibid., 6-7.
}

${ }^{32}$ Ibid., 18. 
military matters is becoming appreciated," it remained that, "we are slow in coming to accept the application of this principle to works of beneficence." ${ }^{33}$ Echoing some of the frustration communicated by Frederick Law Olmsted as he encountered similar challenges in the Civil War, the organization's annual report commented "therefore, we are confronted with the absurd spectacle of 130 different organizations advancing their claims to be the accepted agencies of the American people" in war relief, a position reserved for the Red Cross, "by the proclamation of the President of the United States." 34 Given the size of the armies engaged in conflict, increasing the numbers of wounded and needing care "from the improvements that have been made in the science of killing," the complexity of relief efforts required central coordination..$^{35}$ The Red Cross proposed, in the same way that the Federal government coordinated private industry to propel the war effort, that they should coordinate other nonprofit corporations to ensure efficient war relief..$^{36}$

Additionally, according to their statutory mandate, the Red Cross was compelled to begin planning to support and augment the medical service of the Army and Navy in the event of war. Since the expense of maintaining a robust medical service was beyond the budget capabilities of any military not at war, when conflicts arose, significant ramping up would be required. This new system "will inevitably break down unless the machinery for it is in place and the individual agents are selected and instructed in advance. ${ }^{\prime 37}$ With energy and resources freed up from limiting direct services, the Red
33 Ibid., 27.
${ }^{34}$ Ibid.
35 Ibid.
${ }^{36}$ Ibid.
${ }^{37}$ Ibid. 
Cross produced a novel solution to the possibility of future war. Instead of creating military hospitals out of thin air when warfare began, the organization instead recruited teams of doctors and nurses from every major American city. With each city providing a medical team that could be mustered at a moments notice, for training or deployment, the organization initiated a plan for eventual war. By encouraging local chapters to provide the funding for those units - a form of civic pride - they grew the capacity of the organization without significantly increasing overhead. ${ }^{38}$ But even this new approach provided only a basis for Red Cross operations in the event of war. To operate in the way required of a modern, total war effort, the organization would need to prepare for a larger range of operations.

With war preparation underway throughout the nation, President Woodrow Wilson, who served, as all presidents during this period, as both the leader of the United States and the national Red Cross association, appointed a War Council board to determine how best to structure the nonprofit corporation for war time realities. This committee made a number of swift changes to the structure. Foremost was a transfer of day-to-day leadership from the Chairman of the executive committee to a newly appointed General Manager. Rather than pull a manager from the philanthropic world, the Board of Directors appointed Harvey D. Gibson to fill the position. Gibson cut his corporate teeth at the American Express Company, leaving in 1916 to serve as president of Liberty National Bank, which at the time was one of the nation's largest financial

${ }^{38}$ Ibid., 27-30. 
corporations serving a mostly industrial corporation clientele. ${ }^{39}$ With an active manager capable of bringing an even more corporate culture to the organization, the Red Cross was beginning to resemble the national war effort.

The question of what Gibson should manage became the next hurdle. With a tremendous number of local functions among thousands of chapters, not to mention the centralized duties within the national headquarters, the War Council determined to decentralize the most rudimentary of activities. But this did not mean agency for the individual chapters; instead fourteen geographic divisions were created, with a new hierarchy of middlemen (directors) pulled from the organizational charts of the for-profit corporate world. With directors in place to manage the dictates of the national headquarters and ensure results, Gibson's direct reports moved from a nationwide association to fourteen regional managers. These positions were largely about raising funds from small donors, overseeing the creation of medical supplies locally (such as sewing circles working to create bandages), developing new chapters, and improving existing locals. Activities that required little innovation but constant tending. ${ }^{40}$ This left the leadership in Washington, DC free to dictate organizational needs, without direct management, and allowed energy to focus on more complex activities that directly aided the war effort.

The quest for organizational efficiency, however, tends to spawn departments and payrolls akin to a hydra within corporate culture, and the national Red Cross became no different. The complexity of the organizational structure spawned by the War Council

${ }^{39}$ Board of Trustees, The American National Red Cross: Annual Report (Washington, DC: American National Red Cross, 1918), 8-11.

${ }^{40}$ Ibid., 11-13. 
was peak bureaucracy in action. While the Central Committee remained the governing board of the organization, and the Chairman of that committee continued to operate as the chief executive, new layers of oversight were established. The Central Committee's officers could meet as an executive committee to take action when the full committee was unavailable; the War Council, however, could take action on items related directly to the war effort when the executive committee was unavailable. If the Chairman were unavailable to handle the executive functions of the organization, that fell to the Acting Chairman. Decision making could be delegated to advisory committees by the War Council; of which there were many covering every conceivable aspect of the Red Cross' work in mitigating the war. The War Council also had an Assistant to the Chairman, to whom duties falling under the committees purview could be delegated, but who was primarily charged with leading public relations operations related to the war effort. As well as the addition of the General Manager, who directed the efforts of the fourteen regional leaders, and other departments and bureaus as assigned, which seems to have been most activity directly related to the war. ${ }^{41}$ None of which even begins to mention the litany of new departments created.

As organization flowcharts go, the one representing the new American Red Cross, reads more like parody than reality. One of the organization's original units, the Department of Military Relief, provided direct services to the fighting men. It consisted of the Bureau of Medical Service (responsible for base hospitals, ambulances, sanitary training, and first aid classes), the Bureau of Sanitary Services (which worked to improve sanitation in camp, but did not provide direct education), the Bureau of Camp Services

${ }^{41}$ Ibid., 14-15. 
(largely recreation and hot meals for the troops), the Bureau of Canteen Services (which actually prepared the food served), the Bureau of Construction (generally to construct field hospitals and other medical facilities), the Bureau of Motor Services (to provide non-emergency medical transportation and maintain the organization's fleet of vehicles), and the Bureau of Naval Affairs, which operated as a miniature version of the larger department providing extensive services to the Navy. The Department of Law and International Relations reported directly to the War Council, primarily to provide legal guidance. It oversaw the Bureaus of Communication, Prisoners' Relief, Foreign Relations, Insurance, and Cables. ${ }^{42}$ The Women's Bureau directed the work of female volunteers on the Homefront, which largely meant the manufacture of bandages and other relief supplies. The actual organization of these efforts went through the regional divisions and local chapters, but communicating expectations for quality came from this bureau. The Department of Civilian Relief took on the traditional Red Cross response to domestic disasters, such as hurricanes and earthquakes. The Department of Nursing, previously a bureau under the Department of Military Relief, provided direction to Red Cross nurses working in the field. The recruitment of nurses, along with all other employees, feel instead to the Department of Personnel. Material was managed by the Department of Supplies, consisting of the Bureau of Purchases and a separate Bureau of Supplies (mostly warehousing). An extensive list of other departments, bureaus, and commissions could be provided. ${ }^{43}$
${ }^{42}$ Ibid., 16.
${ }^{43}$ Ibid., 18-21. 
But the best indication of the bureaucratic expansion undertaken by the organization at the outset of the war can be found in the creation of the Bureau of Standards. Consisting of a "special business engineering staff" that reported to the General Manager, it created "operating methods and practices for the various activities of the Red Cross," and was "responsible for the interpretation of organization plans and in coordinating with the heads of Departments and Bureau in effecting economies and increasing the efficiency of operations." 44 The effectiveness of this reorganization is difficult to judge; but it is clear from the outside looking in that the ad hoc management of the Clara Barton era ceased to exist. The new American Red Cross was a fully corporatized national charity, and as such, ready for a leading role in the Associational State's war effort.

In many ways, the record of the Red Cross in World War I speaks for itself. The innumerable recollections of servicemen looking fondly on the organization's efforts (a few of which were highlighted at the opening of this chapter) indicated the outsized impact of the war relief effort. Additionally, the measurable outcomes of the Red Cross' operations are nothing short of impressive. By the end of the war, local chapters manufactured and sent to the soldiers more than 192 million surgical dressings, 10 million hospital gowns, and more than 10 million sweaters and socks. They estimated the value of these and other homespun goods at $\$ 44,171,083.06 .{ }^{45}$ Red Cross canteens, both overseas and serving soldiers being transported domestically, served more than 600,000 gallons of coffee, more than four million sandwiches, almost four million bars of
${ }^{44}$ Ibid., 21.
${ }^{45}$ Ibid., 60-61. 
chocolate, approximately 269,000 hot meals, and distributed exactly 47,704,320 cigarettes (or, at least reported that precise figure). ${ }^{46}$ The Bureau of Sanitary Services inspected more than 9,000 local water supplies, built more than 15,000 toilets, inspected more than 90,000 restaurants and meat processing operations, provided approximately 115,000 doses of anti-typhoid vaccine, 98,000 smallpox vaccinations, and even tested 12,852 cows for tuberculosis. ${ }^{47}$ In France alone, between support for American troops, allied soldiers, and French civilians needing relief, the Red Cross expended more than thirty-five million dollars. ${ }^{48}$ Nowhere in the organization's annual report is an attempt made to count the numbers impacted by the Red Cross' war relief efforts; the sheer volume of numbers made aggregation a fool's errand. And while a nonprofit corporation cannot distribute its profit to a group of investors, practicality requires such organizations to seek revenues to meet operational demands. In the first fundraising drive launched by the Red Cross to aid in war relief efforts, the leadership set the goal at $\$ 100,000,000$. In quick time they accumulated more than $\$ 181,000,000$.

Undoubtedly, part of the success of the Red Cross was the explicit inclusion of the nonprofit corporation in the Associational State. While other organizations contributed to the war effort in meaningful ways, such as the YMCA (discussed below), the Red Cross held a unique distinction in the government-business-nonprofit corporation alliance tasked with managing total war. This became clear July $5^{\text {th }}, 1917$, when the Secretary of War issued General Order No. 82 creating a rank equivalence chart between

\footnotetext{
${ }^{46}$ Ibid., 76.

${ }^{47}$ Ibid., 78-79.

${ }^{48}$ Ibid., 111-112.
} 
standard military titles and the hierarchy of the Red Cross. ${ }^{49}$ While it was clear that this order "conferred no military rank, or office, nor any right to pay or allowance," it did "identify and indicate to members of the land and naval forces that officials of the assimilated rank" should receive "cooperation in the discharge of their functions and that courtesy and respect due to person designated for such important duties to humanity." 50 Immediate acceptance into the Associational State during the Great War - an experience quite different from the Red Cross' Civil War era organizational predecessor - marked not just an important role in the war effort, but also a coming of age and its emergence as a truly corporatized entity.

The decentralized nature of the YMCA left it even less ready to contribute to the war effort. The organization's International Committee, which operated as a coordinating board for the chapters in Canada and the United States (different from the even more internationally focused committee that coordinated among YMCAs globally), seemed to not even recognize the prospect of a war looming. In their 1914 annual report published only a few months prior to the outbreak of hostilities, what others saw as signs of international conflict, they saw as opportunities to grow North American style YMCAs across the globe. The International Committee reported with some glee that international events created a vacuum in both physical education programming and Christian evangelizing in China, and that with the support of provincial leaders, both politically and financially, chapters were launched in four different regions. Likewise, the Japanese

\footnotetext{
${ }^{49}$ Ibid., 103-104.
}

${ }^{50}$ Ibid., 104. 
government, which took over operation of the Korean national railway, made arrangements for the chapters of the American Railway YMCA (a smaller version of a local chapter serving a railway hub for travelers) to being operation in Korea. In India, with the British YMCA's attention turned elsewhere, local chapters, with the financial support of the Indian government, installed the American system of physical education, even paying to bring an American expert to India to lead the effort. And in Mexico, where a revolution continued to rage, the YMCA reported that the Railway chapters initiated by Americans living in the nation continued to thrive, even though the country itself was seeing economic decline in the millions per year. ${ }^{51}$ With little interest in the wider meaning of world events, the YMCA saw nothing but growth and success in their future.

That perspective did not alter with the coming of the war. For fiscal year 1915 to 1916, the awkwardly named International Committee took no action to support the work of YMCAs among the belligerent nations - a different approach from the American National Red Cross - and instead turned their attention inward. The organization undertook a massive study of the relationship between the larger coordinating board, the coordinating committees of states and provinces, and the connection to individual chapters which operated, legally if not in practicality, completely free of any oversight. This is also, however, the first sense offered by the YMCA that they needed to increase their operational capacity. Couched as an improvement to communication and cooperation between the international Committee, state committees, and locals, the

${ }^{51}$ International Committee of Young Men's Christian Associations, Year Book of the Young Men's Christian Associations of North America, May 1, 1913 to April 30, 1914, (New York: Association Press, 1914), 368-369. 
International Committee launched a series of reforms focused on creating new entities and increasing the personnel serving on existing groups and boards. ${ }^{52}$ Though this came in a year in which the organization reduced its overseas operations by more than $\$ 35,000$, some repositioning was beginning. ${ }^{53}$

For fiscal year 1916 to 1917, the North American YMCA finally engaged in the Great War in a meaningful way. The committee that evaluated the relationship of the International Committee to other coordinating and governing bodies, transitioned to serving the soldiers of combatant nations. To aid the work, the General Secretary of the American YMCA assumed direct control of international aid efforts, including serving as the national representative to the World's YMCA Committee. ${ }^{54}$ The organization expended more than $\$ 300,000$ in direct aid to ease the suffering of war for the soldier; the majority of American YMCA activity took place in prisoner of war camps. While the United States remained neutral, the YMCA (much like the Red Cross) was invited into facilities operated by both sides. By early 1917 organization staff could be found offering services to prisoners in camps located in Great Britain, France, Italy, Serbia, Austria, Germany, and Russia. With more than five million men residing in prisoner of war camps throughout Europe, the American YMCA planned a fourfold expansion of services and budget for the 1917-18 fiscal year. As a neutral nation, the United States and its nonprofit corporations held a unique position in the war landscape. Yet, both the nation and it's

${ }^{52}$ International Committee of Young Men's Christian Associations, Year Book of the Young Men's Christian Associations of North America, May 1, 1914 to April 30, 1915 (New York: Association Press, 1915), 341-344.

${ }^{53}$ Ibid., 346.

${ }^{54}$ International Committee of the Young Men's Christian Associations, Year Book of the Young Men's Christian Associations of North America, May 1, 1915 to April 30, 1916 (New York: Association Press, 1916), 8-9 
organizations were already positioning themselves for the possibility of entering the conflict. For the United States government, this meant an increase in the size of the armed services and increase in activity particularly at naval bases. For the American YMCA, this produced growth in staff to serve, and services provided, to soldiers and sailors on standby. In San Francisco, the organization leased a 216 room building to better position staff to support the expanding pacific fleet. For the burgeoning Charleston Navy Yard the national organization raised more than $\$ 200,000$ for a new YMCA headquarters. And in Pearl Harbor, Hawaii, the Royal Hawaiian Hotel was purchased and transformed into a branch of the Army and Navy YMCA. ${ }^{55}$ At that point, even with a clear ramping up of operations domestically connected to the military, no plans to support an American war effort were published. Events of the following year, however, indicate that while nothing was being publicly communicated, much like the United States' prewar planning, arrangements were underway longer than publicly acknowledged.

Much like the Red Cross experience, the coming of war brought a flurry of activity for the American YMCA. Many of these efforts made perfect sense in comparison to YMCA activities at home. Most camps, both domestically and in theater, played host to a YMCA chapter. The organization erected offices, an auditorium, recreations facilities, and meeting rooms, generally. If room allowed, athletic fields were also maintained. With peacetime branches of the YMCA already existing to serve Army and Navy installations, this sudden expansion rested on their foundation, as they provided a model for services and facilities. Much as they did prior to the war, the YMCA, still suggesting its evangelical beginnings, coordinated with the Knights of Columbus and the

${ }^{55}$ Ibid., 28-30. 
Jewish Welfare Board to meet most men's spiritual needs without duplicating efforts. Reflecting similarities of experience to the Red Cross, the organization found itself filling voids in the war effort as it encountered them, taking on activities not generally included in their core mission. While maintaining postal services to and from soldiers in the field fell to the Red Cross to assist, the YMCA found itself soon taking over operation of post exchanges (essentially, a small department store to serve the troops). ${ }^{56}$

To facilitate the YMCA's mission overseas and at domestic camps, the International Committee ceded control of war operations to a War Council. At the same time, in an effort to continue to serve prisoners, the Committee on Work for Allied Armies was founded, in order to create a clear delineation between efforts on behalf of American soldiers and sailors, and the humanitarian efforts in service of all combatants. But the decentralized nature of the YMCA's normal operations largely prevented the creation of an albatross of bureaus, commissions, and departments to support the war, even as corporatization accelerated. It is true that the organization's activities, budget, and personnel paled in comparison to that of the Red Cross - field hospitals being much more expensive and complex to maintain that amusement facilities - an expansion in size and scope did occur. Instead of a commanding bureaucracy, however, the YMCA committed to supporting the war through coordinating committees. Of these new organs, all working under the War Council - the Finance Committee, the Activities Committee, the War Personnel Board, the Committee on American Expeditionary Forces, the Cooperating Committee of the Churches, and the Women's Cooperating Committee success in their efforts could only be found in communication, coordination, and consent

${ }^{56}$ Ibid., 41-42. 
to participate in their activities. Unlike the Red Cross, the structure of the YMCA simply did not allow for centralized command and control, even in times of war. In fact, this cooperative ethos extended beyond the organization itself. To maintain a thoughtful role in the Associational State's war effort, the War Council of the YMCA also created the Committee on Work in War Industries, the Committee for Cooperation with Young Women's Christian Association, and the Committee on Conference with the Federal Council of Churches of Christ in America. ${ }^{57}$

Much like the Red Cross, the record of the YMCA in the war was a remarkable achievement. Even prior to the end of hostilities, the organization maintained more than 500 buildings, with more than 3,000 employees, all in service to America's soldiers and sailors. Resulting in more than 100,000,000 visits to their facilities. They arranged 27,373 entertainment opportunities, exhibited 17,250 motion pictures, circulated more than 24,000 books, organized 45,158 bible classes, and sold more than 64,000 money orders. All of which resulted in more than $\$ 43,000,000$ in expenses for the organization.

While the size of the operations undertaken by the Red Cross and YMCA on behalf of the American war effort is relatively easy to document, the true impact of the organization's activity cannot be calculated - but undeniably contributed the America's success in the Great War. The organization's impression on individual combatants could be immense. Their balance sheets reflect significant investment, and both organization's annual reports demonstrate corporate growth and substantial improvements in capacity. Perhaps the most significant indicator of these two nonprofit corporations inclusion with

${ }^{57}$ Ibid., $42-50$. 
the Associational State's war effort is something that came to light well after the fact. In 1930 the United States Congress undertook efforts to curtail the Espionage Act, a controversial bill passed in 1917 banning activity that undermined the war effort. This act was amended the following year from its simple beginnings to include speech critical of the government and the war effort as an act of treason. In their investigation, members of Congress were surprised to find novel ways in which the act was interpreted. "It became criminal to advocate heavier taxation instead of bond issues, to state that conscription was unconstitutional though the supreme court had not yet held it valid, to say that the sinking of merchant vessels was legal," it even became prosecutable to say that "war was contrary to the teachings of Christ." 58 Most remarkable, Congress discovered that men had even "been punished for criticizing the Red Cross and the Y.M.C.A." ${ }^{59}$ Such was their importance to the prosecution of the war effort; the power of the state was arrayed to protect both organizations as constituents within the Associational State.

The coming of the Great Depression disrupted the Associational State as the primary apparatus for addressing complex national challenges, yet the Red Cross and YMCA continued as the premier examples of nonprofit corporations in the United States. For the YMCA, the end of the war and the decline of the government-business-nonprofit corporation alliance largely meant a return to normal, with each chapter determining their future course. The decentralized nature of the organization left the War Council, and the International Committee, with little need for staffs, large budgets, or bureaucratic forms -

${ }^{58}$ U.S. Congress, Senate Committee on the Judiciary, "Repealing Certain Provisions of the Espionage Act," (Washington, DC: United States Senate, Jun. 5, 1930), 3.

${ }^{59}$ Ibid. 
the YMCA returned to its pre-war structure and continued much as it had. As discussed previously, that still meant the pursuit of a significant corporate culture. As the organization focused more on physical education and wellbeing, further deemphasized the "C," and eventually left the "M" of the acronym behind as well, it assumed its present day form. Which is still a decentralized, chapter led, alliance of equals. The Red Cross, however, chose not to shed its newly acquired bureaucratic nature. Instead, following a highly structured organizational chart, replete with an even stronger corporate culture, allowing it to maintain its position as the nation's preeminent nonprofit corporation. Ironically, this culture, which rendered the organization an excellent partner within the Associational State, also created a culture no longer capable of meeting its mission sowing the seeds for the dissolution of the longstanding government-business-nonprofit alliance. 


\section{Chapter 9}

The Limits of the Associational State

With dramatic scenes of dust storms destroying crops, choking the life out of livestock, and causing mass migration of farmers, it is no wonder that the Dust Bowl (1934-1940) captured the American imagination. But before Woody Guthrie composed songs of dusty woe, or John Steinbeck crafted cultural touchstones, a precursor drought running from the summer of 1930 to early spring 1931 wreaked havoc that rivaled if not surpassed the more famous stories of Oklahoma in the mid 1930s. Centered on the Ohio and Mississippi river valleys, but impacting more than thirty states, the crisis was widespread. With most locations receiving less than average rainfall, such as rural Montana, the impact of losing a year's crop was an economic stressor. In many communities the food supply for livestock diminished quickly, resulting in the unnecessary slaughter of hundreds of thousands of animals; weakening the already troubled market for meat, compounding the economic impact on farmers. ${ }^{1}$ The food supply relied on by humans remained relatively stable, and through locally organized relief efforts coupled with normal rain fall in early spring, by 1931 most communities were on a path to recovery. ${ }^{2}$

${ }^{1}$ David E. Hamilton, "Herbert Hoover and the Great Drought of 1930," The Journal of American History, Mar. 1982, 851-852.

2 To qualify this statement some, the Great Depression was just beginning to unfold, which obviously held serious economic ramifications for most farming communities even after they returned to normal production. In the areas impacted by the Dust Bowl, this relatively short drought was a preview of future deteriorating conditions. 
In many ways America's response to the drought was textbook. Local relief committees, often calling on the financial support of existing community chest organizations, launched efforts to address the needs of local farmers. Railroads reduced fees to help maximize profit margins on agricultural commodities. Meanwhile, the federal government contributed to the effort by coordinating action and disseminating information. For Herbert Hoover, then serving as president of the United States, this response represented the best of the American spirit. In Hoover's mind the 'American system,' or as later scholars termed it, the associational state, reflected democracy in action. Through grassroots and localized efforts, coupled with scientific rationalism and private enterprise, the American people were capable of tackling any challenge. As historian Ellis Hawley explained, the key to this system was Herbert Hoover's vision, who concluded "based on his wartime, engineering, and personal experience," that American civil society "lay in the development and proper use of cooperative institutions," generally, "trade associations, professional societies, and similar organizations among farmers and laborers." 3 This would result in the creation of an almost privately organized government, capable of addressing social ills and taking advantage of opportunities, all while avoiding repressive government bureaucratization, the consolidation of capital and creation of cartels, and cultural atrophy. ${ }^{4}$ In much of the United States, Hoover's system worked as designed in mitigating the drought.

But this was not the case in rural Arkansas, which resting on a weak economic foundation centered on widespread subsistence farming. Further complicated by

${ }^{3}$ Ellis Hawley, "Herbert Hoover, the Commerce Secretariat, and the Vision of an “Associative State," 1921-1929," The Journal of American History, Jun. 1974, 117.

${ }^{4}$ Ibid. 
parochial concerns with maintaining an ethnic socioeconomic order in which African Americans remained at the bottom of the ladder, not to mention structural disorder in the associational state itself, Arkansas remained in distress until rain began to fall again in early spring. Rather than demonstrating the efficacy of the associational state in action, the Arkansas experience with the system illustrated the limits of Hoover's vision. The president's civil society ideal called for volunteerism: voluntary donations, volunteerism in labor to fellow citizens, organized and distributed by voluntary organizations, voluntarily aided by for-profit corporations. But as demonstrated throughout this study, nonprofit organizations are a creation and expression of the market economy. If capitalism became a system in distress - as it clearly did with the coming of the Great Depression - it stands to reason that economic tension touched on all corporations. Even those serving a benevolent mission.

This was certainly the case for the Red Cross, the primary organization tasked with mitigating the drought, as it navigated economic depression. The associational state, for all that it was capable of achieving, simply could not function as intended when volunteerism slipped into half-hearted concern defined by half-measure operations in a desperate attempt to maintain organizational stability. Especially from the nation's primary relief organization facing unending suffering. Though the associational state persisted, the Arkansas drought made clear that the democratization of charity and voluntary action was only capable of so much. When faced with the choice of endorsing this limited, failing system in the face of the Great Depression, the American people chose otherwise. The grand experiment with wielding the associational state to meet major challenges failed. 
By August $1^{\text {st }}$, 1930, the Department of Agriculture understood the full extent of the drought. Their review of the situation examined the impact on the food supply for humans, pasture, future feed production, and livestock expected to be slaughtered to avoid additional feeding costs. In each of these categories the national landscape appeared grim. But the real test of the drought's influence over physical and economic health could only be ascertained by breaking conditions down by state. When looking at smaller units, such as state and county, survey’s produced bright spots. For example, though Indiana suffered from the drought, "a considerable number of farmers are engaged in other pursuits and depend upon home gardens and other food crops for some of their living." In Kentucky, where tobacco production felt the effects of the drought, "it still offers some promise of cash income to farmers." ${ }^{\prime 6}$ Tennessee, which experienced the drought in every county, with the most severely impacted relying on cotton crops as their economic foundation, took solace in the hardiness of the plant. "Cotton is known to be an extremely drought-resistant plant and a fair yield of cotton may be made" All states, even the hardest hit, revealed some cause for hope; except Arkansas.

In Arkansas the Department of Agriculture found the entire state "embraced in the drought," and although "no considerable area of this State is important in the production of livestock," that pointed more to long-term economic weakness than escape from

${ }^{5}$ United States Department of Agriculture Bureau of Agricultural Economics, "Memorandum on the Drought Situation as of August 1, 1930," Aug. 1, 1930, President's Subject Files, Drought Correspondence Box 134, Hoover Presidential Library, 3.

${ }^{6}$ Ibid.

${ }^{7}$ Ibid., 4. 
certain ruin. ${ }^{8}$ "The peach crop was practically a failure and the important cash crop, strawberries, was very short." Individual reports from the state echoed the departments findings. R.E. Bickers, a desperate Arkansas farmer sent his concerns directly to Hoover, reporting "I have even seen no rain in 10 months and no prospects for rain. Unless there is something done and done soon people will suffer. It is getting to be deplorable." ${ }^{10}$ To emphasize his concerns, he relayed to the president that "pastures and fields are drying up. Crops are ruined." ${ }^{11}$ Something had to be done. "We the people of the State of Arkansas need help from somewhere. We will not be able to live through the winter and make a crop," Bickers declared. ${ }^{12}$ One of Arkansas' Senators, Joseph T. Robinson - who would play the role of Hoover's primary antagonist in applying the associational state to this challenge - was even more direct. "The worst condition I have ever known prevails throughout the greater part of Arkansas [there is] an almost complete failure of all agricultural and horticulture crops." ${ }^{13}$ Robinson reported to Hoover that "practically no fruit vegetable seed or foodstuff will be produced, and there will be very little cotton or corn grown" ${ }^{14}$ Hamp Williams, president of the American Hardware Association - just the type of association Hoover believed should play a role in vision of government wired Hoover to support Robinson's observations. "I agree with Senator Robinson crop

\section{${ }^{8}$ Ibid., 4.}

${ }^{9}$ Ibid., 4.

${ }^{10}$ R.E. Bickers, "Letter to Hoover, Aug. 4, 1930," Aug. 4, 1930, President's Subject Files, Drought Correspondence Box 134, Hoover Presidential Library, 1.

${ }^{11}$ Ibid.

12 Ibid.

${ }^{13}$ Joe T. Robinson, “Letter to Hoover, Aug. 5, 1930,” Aug. 5, 1930, Drought Correspondence Box 134, Hoover Presidential Library, 1.

${ }^{14}$ Ibid. 
conditions in Arkansas are growing worse every day... ${ }^{15}$ Clearly, the federal government needed to do something.

There were any number of opinions as to what should be done to address the situation in Arkansas. Bickers, an unconnected citizen of Arkansas, called on Hoover to do 'something.' A mass meeting in Sharp County, Arkansas approved a resolution calling on Hoover, "with the view of preventing the speculators and the grafters from bringing about further disaster and distress among the people, and such other further steps as for such relief" as necessary. ${ }^{16}$ Hamp Williams, perhaps reflecting Hoover's associational state, could only offer that "we are fortunate indeed to have a man like your good self as our leader in this great catastrophe I am ready to serve my state in any capacity or do anything you say for the relief of the farmers" ${ }^{" 17}$ Sen. Robinson, however, provided concrete policy solutions for coming to the aid of Arkansas. "To avoid great suffering and irreparable economic loss it is suggested that the Federal Farm Board use such amounts of the revolving fund as may be found necessary upon a quick survey to meet immediate requirements to prevent suffering." 18 The primary problem, beyond alleviating short-term food shortages, was to ensure farmers access to the credit necessary to propel them through the next planting season. The Federal Farm Bureau could extend credit to farmers without collateral, a challenge for many an Arkansas farmer, and "I am sure the revolving fund thus employed will be replenished by Congress at the first opportunity

15 Hamp Williams, “Telegram to Hoover, Aug. 8, 1930,” Aug. 8, 1930, Drought Correspondence Box 134, Hoover Presidential Library, 1.

${ }^{16}$ Mrs. W.A. Oldfield, "Letter to Hoover, Aug. 7, 1930," Aug. 7, 1930, Drought Correspondence Box 134, Hoover Presidential Library, 2.

${ }^{17}$ Williams, 1.

${ }^{18}$ Robinson, 1. 
and that such additional funds as may be required to the making of a crop in 1931 will be authorized..."19 Hoover's response, "that the federal government will leave no stone unturned to assist all local authorities in the emergency," forecast the flashpoint between the Senator and the President in this matter. ${ }^{20}$ Robinson wanted strong, decisive, direct federal action. Hoover took a different approach.

August $5^{\text {th }}, 1930$ Hoover issues his first public statement regarding the drought, commenting that "the measures of assistance that the Farm Board and other agencies of the Federal Government can and should undertake are being determined." ${ }^{21}$ From his perspective, "it is evident already that large measures of feed movement to livestock in the drought areas or movement of animals out of the worst areas will need be undertaken later in the fall." 22 But, "it is too early to determine the precise character of relief; much depends upon the further spread of the drought." ${ }^{23}$ The first step Hoover took was collecting information. Following his playbook from previous relief efforts, the president called a meeting of governors from the affected states to collect information, determine local relief capabilities, and map a path forward. ${ }^{24}$ The plan created at that meeting reflected the president's associational approach.

${ }^{19}$ Ibid.

${ }^{20}$ Herbert Hoover, “Telegram to Honorable Joe T. Robinson, Aug. 6, 1930,” Aug. 6, 1930, Drought Correspondence Box 134, Hoover Presidential Library,, 1.

${ }^{21}$ Herbert Hoover, "Statement on the Drought," Aug. 5, 1930, The American Presidency Project, 1.

22 Ibid.

${ }^{23}$ Ibid.

${ }^{24}$ Herbert Hoover, "Statement on the White House Conference on Drought Relief," The American Presidency Project, Aug. 14, 1930, 1. 
First, Hoover made clear the objectives of the relief effort: mitigating hunger over the winter; prevent the slaughtering of livestock just to avoid feeding them; and maintaining public health. Next, he outlined how these goals were to be achieved, which included facilitating private loans to impacted farmers, working through business associations to achieve reductions in railway rates, finding ways to increase non-farm employment, and the Red Cross providing direct relief. Last, the president provided a system for organizing the relief efforts. In each impacted state the governor took responsibility for forming a central relief committee, to be comprised of leading citizens, representatives from the state's agriculture department, bankers, railway executives, farmers, and a representative from the statewide Red Cross organization. The central committee should focus on identifying the specific counties needing intervention, and then create a county relief committee consisting of the same constituent groups as the statewide version. It was left to the county committees to accept and verify applications for aid, coordinate the distribution of supplies and relief, and when low on resources to appeal to the statewide group. The state committee, if found lacking of resources, would appeal to the national relief committee which then mustered needed supplies and funds. The national committee, reflecting the same constituencies as the other relief committees, consisted of a representative from “...the Department of Agriculture, the Federal Farm Loan Board, the Red Cross, the American Railway Association, and the Public Health Service." 25

In bringing each of these groups together as one relief effort, be it at the national, state, or county level, Hoover envisioned an efficient operation with clear lines of

25 Ibid. 2-3. 
communication and responsibility. The Federal Farm Board and Federal Farm Loan Board were tasked with arranging and expanding credit for farmers needing assistance with the next planting season. The railways were called on to further discount rates if necessary, but also to return the transportation market to equilibrium where possible. The agriculture department would act as an information hub, in particular when it came to the transportation of livestock to available pasture. ${ }^{26}$ But above all other measures, "the burden of effective organization to meet the situation over the winter in the acutely affected counties rests primarily upon the counties and States themselves" though, "supplemented by such cooperation and assistance as may be found necessary on the part of the Federal Government." ${ }^{27}$ The response to the challenge was to be efficient, localized, rational: a presentation of Hoover's philosophy of a democratic and voluntary associational state.

The stratified and hierarchical nature of the response, however, produced an environment rife for avoiding responsibility; for all except the Red Cross. Hoover remarked, shortly after relief efforts commenced, that "in order that there may be no failure to cover any case of distress...the Red Cross has given instruction to all their county agencies to take care of the situation." ${ }^{28}$ In other words, the Red Cross was left dealing with the fallout of the disaster, particularly in Arkansas. As others reduced or mitigated their responsibility to the effort - like Harvey Couch, the railroad representative to the Arkansas committee, who offset rate reductions at the Louisiana \&

\footnotetext{
${ }^{26}$ Ibid.

${ }^{27}$ Ibid., 1.

${ }^{28}$ Herbert Hoover, "Statement on the Organization of Drought Relief," The American Presidency Project, Aug. 19, 1930, 3.
} 
Arkansas Railroad by slashing wages, compounding the overall economic impact of the drought - the Red Cross struggled to manage the disaster. ${ }^{29}$ It did not go well.

At the outset Hoover, who served as president of the Red Cross, and the Chair (which was the more directly involved of the two leadership positions), John Barton Payne, agreed that the organization should earmark $\$ 5,000,000$ for the relief effort. Working under the belief that wealthier states would be able to manage without external help, an assumption that largely proved true, Payne and Hoover felt that limited funds would be needed to address the situation in the poorer southern states. Working from the same organizational structure as the overall relief effort, Hoover and Payne implemented a Red Cross operation in which the county organizations coordinated the work of local chapters. If short of supplies or funds, the counties Red Cross would then appeal to the state organization, which communicated directly with the national Red Cross. When resources diminished locally, within the state, and nationally, Payne, working in conjunction with Hoover, could initiate a national fundraising effort and refill the Red Cross' coffers. While the system proved quick and responsive in the short-term, by the time winter approached the localized relief efforts were being overrun. ${ }^{30}$ The disparity between what the organization provided and what was needed by the victims of the drought became evident on January $3^{\text {rd }}, 1931$, when the Red Cross faced an open rebellion.

${ }^{29}$ F.D. Laudemann, “Telegram to Hoover,” Jan. 19, 1931, Presidential Papers Secretary's File: Harvey Couch, Hoover Presidential Library, 1.

${ }^{30}$ David E. Hamilton, "Herbert Hoover and the Great Drought of 1930," The Journal of American History, Mar. 1982, 857-858. 
In the township of England, Arkansas, for the days prior to the riot, the county Red Cross found itself without the blank forms necessary for farmers to request aid. Since the policies of the organization required appropriate paperwork and verification of each claim, they simply ended relief efforts. Beginning with forty-seven tenant farmers demanding assistance, their numbers soon grew to over five hundred, both white and black. Local Red Cross representatives made a mad dash to Little Rock for a stack of required forms, returned to England, and doled out rations for more than 500 families. Interestingly, the farmers of that region had become so accustomed to living at subsistence levels that they did not balk at the $\$ 2.75$ worth of aid offered each family for a period of two weeks - a measly sum being widely criticized outside of rural Arkansas. In response to questions about the amount distributed per family, John Barton Payne could only offer that rations were set according to local conditions and traditions. ${ }^{31}$

As can be imagined, all too often 'local conditions and traditions' became code for maintaining the racial hierarchy. The Red Cross' insistence on verifying claims for relief fell particularly hard on African American sufferers. In some cases, black applicants, unlike white farmers of similar means and condition, were required to perform work for other farmers before receiving rations. Since the local committees represented the interests of the market economy, and many recalled that in the Mississippi river flood of 1927 "how hard it was to get labor after the ' 27 flow, when people were allowed to loaf and eat," African Americans were largely allowed to suffer. ${ }^{32}$ One local dignitary even went so far as to state, "we do not believe we should give enough food to be

\footnotetext{
31 Ibid., 309-310.

${ }^{32}$ Ibid., 311.
} 
comfortable for this would destroy the incentive of our negroes to work and might ruin our labor force for years." ${ }^{33}$ The Red Cross continued to work as an ancillary of the market economy - as it did under Clara Barton's leadership as well - even if that included maintaining a nefarious socioeconomic labor system. But, as dedicated as the Red Cross demonstrated it was to maintaining the status quo, and returning drought victims to something resembling economic independence, they felt little responsibility for the trajectory of relief efforts. From their perspective, the Red Cross operation was performing exactly as it should. Dissatisfaction with the organization was displaced frustration with the credit system, which was the government's responsibility.

In his annual message to Congress at the end of 1930, Hoover provided a review of relief efforts. To that point, the Red Cross expended only $\$ 500,000$ of the $\$ 5,000,000$ budgeted to ease drought suffering. While he acknowledged that more would be needed for the winter, this was a good sign. The Farm Loan Board ramped up credit operations, and the Federal Farm Board extended support to farming cooperatives (another type of business association central to the maintenance of the associational state). Yet, more support was needed. "In order that the Government may meet its full obligation toward our countrymen in distress through no fault of their own," Hoover informed Congress, "I recommend than an appropriation should be made to the Department of Agriculture to be loaned for the purpose of seed and feed for animals." 34 But instead of being direct aid, "its application should as hitherto in such loans be limited to a gross amount to any one

33 Ibid.

${ }^{34}$ Herbert Hoover, "Message of the President of the United States," 1930, 6. 
individual, and secured upon the crop." ${ }^{35}$ As for continued need of relief, "the Red Cross can relieve the cases of individual distress by the sympathetic assistance of our people." 36 Transmitted in early December, before the England riot, and even before the Red Cross began distributing rations, it appeared that the federal government would take the steps needed to initiate a direct relief effort.

Initially, Hoover hoped to avoid direct Federal government involvement in the farm credit system. The Farm Board, working as the Farm Loan Board, already had programs in place to extend credit to farmers needing assistance in preparing for the next planting season. But loans through those programs required collateral beyond the return on the crop. To address farmers with little personal property or resources, Hoover encouraged the creation of 'Agricultural credit corporation,' which would organize locally to muster resources, secure loans from traditional banks, and funnel funds to farmers needing help. ${ }^{37}$ Even with these groups in place, farmers found that their lack of property and stature left them in the same place collectively as it did individually. Additionally, with the Great Depression taking hold, and the drought disrupting local economic activity, more than 120 banks failed between August and December of 1930 in Arkansas. So even farmers with the means of arranging credit found themselves without a bank from which to borrow, nor access to their limited cash already held in deposit. ${ }^{38}$

35 Ibid.

36 Ibid.

${ }^{37}$ Hamilton, 855.

${ }^{38}$ Harry C. Couch, "Telegram to Hoover," Dec. 22, 1930, Presidential PapersSubject File: Drought-Correspondence 1930, Oct.-Dec., Hoover Presidential Library, 1. 
Begrudgingly, Hoover called for a direct loan program via the Department of Agriculture. ${ }^{39}$

In November, 1930 members of Congress began considering the possibility of a farm loan program, with some projecting a price tag of $\$ 125,000,000$. After surveying the estimated needs of individual states via their agriculture departments, the leadership of the House Agriculture committee agreed to a bipartisan proposal of $\$ 60,000,000$, which received the support of Agriculture Secretary Arthur Hyde. But Hyde's support of the bill came with a significant caveat: the loans had to be limited to seed and feed for livestockthey could not be used to sustain humans. While Hoover shared Hyde's concerns that anything resembling direct aid to people would be extended to urban areas by a grasping Congress, he made a tactical error. Rather than working from the agreement Hyde reached with Congress, Hoover instead asked a bureau director in the agriculture department to draft legislation calling for a loan program funded at only $\$ 25,000,000$. When the new version of the bill became public, shockwaves of anger and disbelief surged through the halls of Congress and Hoover's own administration. The Bureau of Agricultural Economics responded by commissioning two independent studies in an attempt to ascertain the size of the needed program. The calculations came in at $\$ 55,645,000$ and $\$ 61,755,000 .^{40}$

In response, the Democratic leader of the House Agriculture Committee, James V. Aswell of Louisiana, proposed his own version, based on the original agreement with Hyde. In a political blunder of his own - an attempt to widen support for the loan
${ }^{39}$ Ibid., 859.
${ }^{40}$ Ibid., 864-865. 
program - Aswell removed the seed and feed limits, allowing loans for the any aid needed by people, and expanded it to urban workers as well. This mistake left the supporters of a more conservative approach with two strong defenses of their plan. They argued that if the larger bill passed it would disrupt and diminish local relief efforts, create a dole system, and hamper the work of the Red Cross. It was argued by House Majority Leader John Q. Tilson, among others, that it was "in effect dispensing charity and disguising it as a loan," a plan he found of "revolutionary character."41 Furthermore, with Hoover's longstanding reputation as the nation's premier disaster responder, coupled with the claims of other relief professionals that twenty-five million would more than cover the need, the smaller sum was seen as keeping in-line with expert consensus. ${ }^{42}$ After significant legislative wrangling, in early January a relief bill passed both houses and promptly received Hoover's signature. While anxious senators were able to increase the total relief to $\$ 45,000,000$ and restrict the focus to those directly impacted by the drought, aid remained limited to just seed and livestock feed loans. Direct relief, as planned at the outset, was once again left to the Red Cross. Unhappy with this arrangement, some senators envisioned a work around that would expose the limits of the associational state.

An attempt at Congressional intervention in the Red Cross' relief effort could have been avoided. But from the beginning of the crisis the Red Cross seemed less than dedicated to relieving the drought. One problem was that "the American public has

${ }^{41}$ James L. Fieser, "Confidential Letter to Central Committee," Presidential Papers - Subject File: American National Red Cross, Correspondence 1930 JulyDecember, Hoover Presidential Library, 1.

${ }^{42}$ Hamilton, 866-867. 
become well acquainted with the fact that normally the Red Cross does not engage in disaster relief work in connection with economic hazards such as crop losses and industrial depressions. ${ }^{" 43}$ Hurricanes, earthquakes, floods, even foreign war relief, all fell under the auspices of the organization. Drought, however, like industrial depressions, lay outside their scope in large part because they were economic challenges; issues that were unlikely to be resolved quickly. With an unknown window of activity, it was not clear to the Red Cross how fundraising could be sustained indefinitely. In the case of this drought, however, they agreed to intervene. First, there were just too many impacted for the suffering to be ignored. Second, it was the worst drought on record, and perhaps, the worst that would ever exist. Since this environmental catastrophe was so cataclysmically awful, and unemployment always existed in industrialized societies, it was in their estimation reasonable to respond to the drought but ignore the looming crisis in America's cities.

Long since passed were the days of Clara Barton riding into town on the first rail out of Washington, DC to personally survey the damage, assess the needs, and begin distributing aid. Instead, the fully corporatized version of the Red Cross in 1930 undertook a survey of local newspaper editorials to help plan next steps. Of the eightyseven editorials examined by the organization, they found that $44 \%$ believed that "states and communities should solve their own problems," while 31\% "mention Red Cross mass action now or later." 44 Yet, those editorials calling for Red Cross intervention were

\footnotetext{
${ }^{43}$ DeWitt Smith, "Weekly Drought Relief Report," Sep. 20, 1930, Presidential Papers-Subject File: Drought-Correspondence 1930, Oct.-Dec., Hoover Presidential Library, 1. ${ }^{44}$ Ibid.
} 
left out of the report, instead only opposing excepts were reprinted. The Shreveport Journal wondered what the cost would be to communities receiving Red Cross aid, noting that accepting handouts during previous floods resulted "more in loss of selfrespect and manhood than anything ever before experienced." ${ }^{45}$ The Galveston News asserted that states were becoming too quick to ask for external aid, claiming it "is a habit which encourages paternalism and vitiates state morale. Texas grew to its present greatness chiefly by solving its own problems. ${ }^{46}$ And the Sentinel Record of Hot Springs, Arkansas heaped praise on the organization, bestowing it the title of "greatest first aid institution in the world," detailing its achievements, and noting that "it fills more gaping mouths, and empty stomachs, and puts more warm clothing on cold backs than any institution that ever existed." ${ }^{47}$ But this drought “isn't for Red Cross. Instead of an emergency situation, another exists. The farmer isn't yet in a position to be found in the soup line." ${ }^{48}$ The organization's leadership agreed, and while relief operations commenced, they stayed away from direct aid to humans, instead focusing on stabilizing and reinvigorating the market economy of rural communities. ${ }^{49}$

After less than a month in the field, by October, 1930, citing "increased morale," specifically in Arkansas, where the drought was most damaging, the Red Cross made the bizarre decision to close headquarters for the state, opting instead to coordinate their effort from St. Louis. ${ }^{50}$ To that point, the Red Cross earmarked approximately $\$ 450,000$,

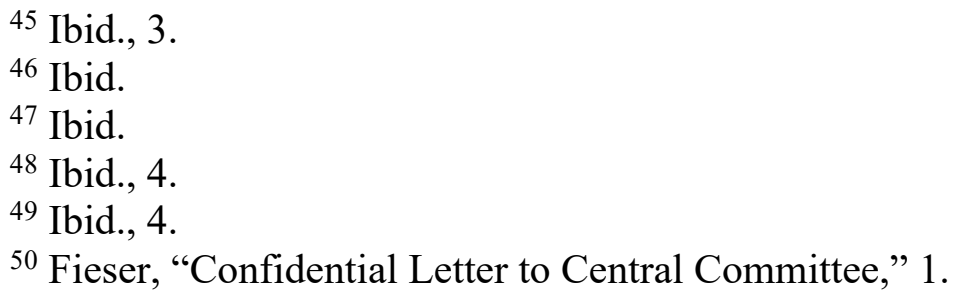


mostly in seed, leaving $\$ 4.5$ million from their relief budget in reserve. Even with this miserly sum, "it has been done with the understanding that in so far as possible chapters would raise funds locally to meet part of the cost," explained James L. Fieser, the acting chair of the central relief committee, "we had hoped the chapters might raise as much as a third on the average but they are doing considerably less." ${ }^{51}$ With less cash being raised in local communities, an unanticipated byproduct of the Great Depression, instead of dipping further into the relief fund budget, the Red Cross pulled back. In moving their headquarter, the clearest sign of attempted decommitment, "we will not only effect some administrative economies but will" Fieser hoped "serve to divert attention as long as possible from the Red Cross and thus strengthen the efforts locally to develop other means, such as employment and credit, to meet the situation." ${ }^{52}$ What they desperately wanted to avoid, and therefore operate as if they were not present at all, was to provide direct food relief.

While the national and state organizations tried to avoid feeding farmers, in some communities, local chapters were already providing rations to a handful of families. Yet, "without actual case investigations, there is no way of determining accurately how many families should probably be fed by the Red Cross. ${ }^{~} 53$ Relying on the knowledge of their corporatized workforce, the organization did provide rough estimates. In Arkansas alone they expected to provide weekly rations to more than 40,000 families once direct food relief began; approximately 107,000 families throughout all of the impacted areas. "This would be an absolute minimum, assuming that feeding could be limited strictly to those

\footnotetext{
51 Ibid., 1-2.

52 Ibid., 1

${ }^{53}$ Ibid., 5.
} 
families whose problem grows out of the drought." ${ }^{\circ 4}$ Casework and investigation were required to ensure the organization did not accidentally succor the lazy or unemployed. But, "because of the large number of counties affected, it would not be possible to provide trained case workers for each county." 55 To ascertain the unmet relief still needed, the national committee asked local chapters to estimate the number of families needing assistance. Their aggregated calculations multiplied the need by two.

Especially when prioritizing institutional needs and interests above the hunger suffered by hard luck farmers, the Red Cross found themselves in a precarious position. By January $1^{\text {st }}$ of 1931 , realities of the available food supply could no longer be ignored, and the organization began widely distributing rations. By January $3^{\text {rd }}$ the tenant farmers in and around England, Arkansas revolted against the corporate culture of the Red Cross, demanding aid without submitting paperwork. By January $10^{\text {th }}$, Hoover, as president of the national Red Cross, authorized the organization's Chair, Payne, to undertake a fundraising campaign on behalf of drought. This represented the organization, finally, committing to mitigating the crisis. Even then the decision to commence in earnest, at that exact moment, was a calculation driven by revenue concerns. As Hoover explained in an internal letter to Payne, "it was felt," at the onset of the crisis, "that it would not be possible to measure the volume of requirements until we had reached the early stages of winter" 56 But this was not the only consideration. "In any event, it was desirable that the Red Cross postpone any appeal until such time as the Community Chests and committee

54 Ibid.

55 Ibid.

${ }^{56}$ Herbert Hoover, "Letter to John Barton Payne,” Jan. 10, 1931, Presidential Papers - Subject File: American National Red Cross, Correspondence 1930 JulyDecember, Hoover Presidential Library, 1. 
on Unemployment Relief in the larger cities should have further advanced the raising of their funds." The Red Cross, with Hoover's approval, waited to raise funds for this effort until the winter, so as to avoid the traditional community chest and local charity annual drive campaigns of the fall. Payne wanted to avoid competition. Until a full campaign could be launched, the Red Cross would simply drag their feet. To his credit, Hoover seems to have been unaware that the Red Cross' leadership was doing everything in its control to avoid spending money on drought relief. All of which created an ideal environment for Congressional intervention.

When John Barton Payne appeared before a Senate committee on January $5^{\text {th }}$, 1931 he was asked to provide an update on the drought stricken areas of the country, report on the Red Cross' ability to meet the conditions, and discuss the organization's impressions of what was happening in cities and towns as a result of the unfolding depression. Payne was mostly transparent when discussing the conditions on the ground and the nonprofit corporation's response. Beginning by noting that the Red Cross undertook relief work at Hoover's request, Payne commented that "in solving the many economic and social problems arising from the drought, it was considered essential that the Red Cross remain in the background in so far as possible." ${ }^{57}$ Instead of stressing fundraising concerns as the cause of taking a secondary role, Payne appealed to the longstanding American ideal of individualism, stating "the welfare of the individual drought sufferer could best be promoted by having him solve his own problem, if he

57 John Payne Barton, "Statement of Hon. John Payne Barton, Chairman of the American National Red Cross," Jan. 5, 1931, Senate Report, 9. 
could, through normal banking and commercial channels." ${ }^{58}$ Those legislators present, in particular those who witnessed an impassioned speech on the Senate floor the day before delivered by America's first female Senator, Hattie Caraway of Arkansas, understood that those normal channels were broken. This led to a number of uncomfortable questions for Chairman Payne.

Senator Lawrence Phipps of Colorado asked what had been required of the Red Cross for their last major relief effort, flooding along the Mississippi in 1927. Payne informed the committee that at the height of the disaster they operated camps housing more than 600,000 refugees, with a total fundraising effort of $\$ 17,000,000$. Phipps proceeded to read some of Caraway's statement from the day before, who noted that "the Red Cross is not in any position to care for the situation. The Red Cross has never been able to visualize the wide extent of the suffering" ${ }^{\circ 9}$ She informed the Senate of countless letters and telegrams received by her office, from all over Arkansas, representing every socioeconomic class and profession, "telling of the situation in my state. It is simply appalling. I know they are not misrepresenting it, because all of us have a State pride which makes us shrink from wanting to parade the suffering which exists in our State and our inability to take care of it." ${ }^{60}$ Calling into question the Red Cross' relief strategy, Caraway pressed her claim: "I do not think anybody would imagine that the distribution of $\$ 2.75$ to a family without a bite to eat is taking care of the situation." ${ }^{61}$ Phipps asked
58 Ibid.
${ }^{59}$ Ibid., 12.
${ }^{60}$ Ibid., 13.
${ }^{61}$ Ibid. 
Payne to respond. He simply stated: "I would, with great modesty, say that no such situation exists." 62

As Senators poked and prodded the Red Cross' relief effort, Payne continued to deny conditions were as bad a reported, asserting that the Red Cross was in complete control of the situation, offering only vague responses. When asked what the organization raised from small towns, counties, and states in the impacted area, Payne responded with an anecdote instead of a number:

"Let me give you a little illustration of that, Senator Phipps. I cannot give you the name of the county, because it does not come to me. But, there was a county in Mississippi, where we have a very good Red Cross chapter, and an ex-judge was at the head of it, a fine man. Well, he sent us a most appalling request, and we sent one of our expert men right straight down there, and they sat down and talked, and the judge told him what they needed. He said, "yes, but what have you done locally? What have you tried to do?" Well, he said, "We have not done much." "Well, but," our representative said, "do you not realize this is a local matter? You know these people. They are your friends and your neighbors. We are expecting you to deal with the situation to the extent of your resources." And, that is the policy of the Red Cross. Well, at the end of the conversation, the result was that they raise $\$ 3,700$ in that county, and the judge himself said that he had perhaps been remiss, he had intended to give $\$ 100$ and had not given anything. He shelled out his hundred. And, that is what is happening." 63

${ }^{62}$ Ibid.
${ }^{63}$ Ibid., 16. 
Phipps responding, inquiring if that method was working in that county. "For the time," Payne responded, "for the time." 64 Unconvinced, Senators continued to press Payne on the nonprofit corporations relief fund.

The opening salvo came from Royal S. Copeland of New York. Reflecting on Payne's testimony, "The thing I have in my mind, and I have no doubt that it is in the mind of every Senator, is that we want the Red Cross to have all of the money it needs to do this work, as you feel it ought be done." ${ }^{65}$ With so little budgeted for drought relief, as compared to the cost of flood aid in 1927, Copeland wished to see more allocated. Payne responded, "if we get toward the bottom of the barrel, we will yell." ${ }^{66}$ Sam G. Bratton of New Mexico inquired what was to done for unemployed urbanites - nothing; while Carl Hayden of Arizona asked if the American people ever failed to answer the Red Cross' call for fund - "never," responded Payne. ${ }^{67}$ The heart of the matter before the committee that day, came in the form of question from Copeland: "I suppose that you would not refuse a liberal appropriation from the Government, if it saw fit to give it." 68 Payne, pointing to tradition, commented that the Red Cross "never asked for a cent from the government."69 "You would not," the Senator mused, "refuse it?"70 Deflecting, Payne offered that it was not possible to accept something that was not officially offered. ${ }^{71}$

${ }^{64}$ Ibid.

${ }^{65}$ Ibid., 17.

${ }^{66}$ Ibid.

${ }^{67}$ Ibid., 18 .

${ }^{68}$ Ibid., 17.

${ }^{69}$ Ibid.

70 Ibid.

${ }^{71}$ Ibid. 
Senators pursued various lines of questions, eventually returning to Copeland, who began pointing out that humanitarian need within the country was significant, not just in rural areas, but in the cities experiencing the depression, and that if $1,000,000$ people needed aid, that left each person with $\$ 4$ as presently budgeted by the Red Cross. Engaging Copeland, Reed Smoot of Utah chimed in, declaring "so far as I am personally concerned, I would like to see whatever money we appropriate placed in the hands of that organization to be expended."72 Ignoring that the Red Cross was actively avoiding relief related to the depression, and therefore uninterested in any funds available for that purpose, Smoot pressed on, returning to the drought. "Mr. Payne, as chairman of the Red Cross, do you believe that your organization, if provided with the money, can reach all of the needy ones in every section of the country."73 Incapable of not touting their efficiency, Payne responded, "if it is humanly possible for them to be reached, we can reach them." ${ }^{\text {"4 }}$ While Payne may have been bragging on his team's capabilities, this only provided Senators with further ammunition.

Copeland, becoming more direct, queried, "is the Red Cross holding to the fetish to the extent that it would not accept, or does not desire to accept, money from the Government, that it prefers to continue its efforts under the former system?"'75 After assuring the legislators that he would answer the question of government financial support directly, Payne began to equivocate. While he served as chair of the organization, the central committee - responsible for governing the organization - consisted of

\footnotetext{
72 Ibid., 22.

${ }^{73}$ Ibid., 23.

${ }^{74}$ Ibid.

${ }^{75}$ Ibid.
} 
seventeen other people. Without consulting them, he could not give a precise answer. ${ }^{76}$ After some back and forth, something of a consensus appeared. All of the senators, even those who supported an appropriation for the Red Cross acknowledged that Congressional action would impact the long-term strength of the organization. It would lead to Americans, in future crises of more manageable scope, declaring "Let the Congress do it." "77 With the intensity of the drought, the suffering it brought, and lack of rainfall on the horizon, those Senators desiring a more active federal response saw coopting the Red Cross as the only path forward. Hoping to bring the matter to a close, Chairman Gilbert N. Haugen of Iowa declared, "I am going to ask for a direct and concrete answer [as to] whether the American Red Cross can provide adequate relief to all needy person in the future. Can you give me as correct an answer as possible?"78 Payne, hoping to head off any further discussion of a public appropriation, provided a clear answer: "It is our conviction, with the funds now available, and with such funds as we will be able to obtain from public contributions, everything and when necessary; yes."79 Three days later, after consulting with Hoover, the Red Cross initiated their first drought relief fundraising campaign. ${ }^{80}$ The damage, however, was already done. The stream of letters and telegrams from Arkansas, in addition to Payne's generally vague answers and clear evidence of the organization's lack of commitment to drought relief, provided more than enough justification to fuel the proposed appropriation.
${ }^{76}$ Ibid., 24-25.
77 Ibid., 25.
${ }^{78}$ Ibid., 26.
79 Ibid.
${ }^{80}$ Hamilton, 870. 
As could be expected, the senior Senator from Arkansas, Joseph Robinson, led the charge. On January $14^{\text {th }}, 1931$ he filed a bill providing the Red Cross with $\$ 25,000,000$ in aid. Under his plan relief funds could be allocated to both rural and urban Americans, regardless of whether it was drought or depression causing distress. While there was support for the measure in the Senate, perhaps even a majority, the House of Representatives, where Hoover still held sway (the Democratic majority elected in November would not be seated for some time), posed a significant obstacle. As did Hoover, whom Secretary of State Henry Stimson recorded in his personal diary that the president was "full of fight" over the proposal. ${ }^{81}$ In many ways, the political considerations were purely academic. The Red Cross, via Chairman Payne, immediately made it clear that the organization would not accept the appropriation. The historical record is silent on their deliberations, but undoubtedly Hoover, as president of the organization, played a role in the decision. ${ }^{82}$

While Payne remained publicly silent, Hoover made his perspective clear. Acknowledging the extent of the drought, Hoover granted that "we are faced with a national emergency," but, "those in need in our larger cities are being and will be provided for through the generosity and self-reliance of the citizens of those counties." 83 In rural America, where the drought was compounding the economic depression, "states are not in a position adequately to help themselves and must look to their fellow citizen

81 Ibid.

82 Ibid.

${ }^{83}$ Herbert Hoover, "White House Statement of the Formation of a Committee of Leading Citizens to Aid the Red Cross Drought Relief Campaign," The American Presidency Project, Jan. 18, 1931, 1. 
for temporary assistance. ${ }^{\circledR 4}$ Without mentioning the proposed appropriation, Hoover spoke to the heart of the matter, reminding his audience that "the American way of meeting such a relief problem has been through voluntary effort and for many years this effort has been centered in the American Red Cross," and organization of significance as it was "created by the people themselves to act in just such emergencies." ${ }^{85}$ Even though the condition in the drought area appeared bleak, "it is essential that we should maintain the sound American tradition and spirit of voluntary aid in such emergency and should not undermine that spirit which has made our Red Cross the outstanding guardian of our people in time of disaster." ${ }^{86}$ Above all, even when faced with starvation, the tradition of Americans investing in a voluntary organization they believed in to address an issue they found concerning - the Red Cross as part of the associational state - had to be maintained.

Even with the Red Cross' new fundraising in response to the proposed appropriation, it was difficult to gain ground. Attempting to avoid fully committing to the effort, the organization continued to offer paltry rations to the farmers. By early February, activist Senators began mounting a renewed effort at a relief bill. Hoover was forced to acquiesce to their demands that funds loaned to farmers moving forward could be used to feed humans in addition to livestock. ${ }^{87}$ The Red Cross with its inaction and lackluster fundraising, was simply incapable of meeting the challenge.

\footnotetext{
${ }^{84}$ Ibid., 1-2.

${ }^{85}$ Ibid., 2.

${ }^{86}$ Ibid.

${ }^{87}$ Hamilton, 873.
} 
As much as Hoover continued to advocate for his version of civil society and that vision's ability to address any challenge, by 1931 Hoover's longstanding reputation as the nation's premier humanitarian and organizer was fading from view. The associational state, readily accepted by Americans throughout the 1920s, culminating in his election in 1928, by 1931 was profoundly out of step with reality. From 'Hooverville' to 'Hoover Hogs' to 'Hoover Flags,' the president's name became synonymous with the signs of failure evident in the United States. The economy was failing. Farmers were without water. The federal government had no answers. And, inexplicably, even the nation's most renowned nonprofit corporation was helpless to answer the call for significant relief.

The greatest irony in Hoover's vision of American civil society - an idea we have been perhaps too quick to dismiss from history given that cooperation between the federal government and nonprofit organizations continued even with the coming of the New Deal, and persists into the present - is that what made the associational state worthy of substantial trust is what made it incapable of responding. For an organization to be welcomed by government and become an indispensable arm of civil society, it had to project efficiency, conservative financial management, a bureaucratized hierarchy driven by policies and procedures, and appropriate male leadership. In other words, informal charities need not apply. Only nonprofits embracing a corporate culture found a place in the associational state. What brought the Red Cross to the table, in the years following Clara Barton's resignation, were the very things she fought so desperately to avoid. Systems replaced flexibility. Forms and verification replaced finding those who needed aid. Men replaced a women. When the associational state faced its toughest challenge, Hoover needed a Barton; but Clara instead of John. The Red Cross' failure to address the 
drought in an active, humane manner exposed the limits of the associational state. When the crises were extreme they required associations to care more about their nation than their operation. Corporations, both those that distribute a profit and those that do not, are simply not built that way. Regardless of their mission. 


\section{Chapter 10}

\section{Conclusion}

It is difficult to determine where Herbert Hoover's thoughts on the role of government in relieving economic distress met with the Red Cross' concerns about becoming a quasi-governmental entity. Perhaps these two philosophical approaches were so rooted in the same mindset that parsing one from the other would be an unprofitable exercise. Regardless, the outcome of these two viewpoints, rather than protecting the "American system" resulted instead in imposing a ceiling. Relieving the distress in Arkansas would require a significant financial investment at the exact moment that the Red Cross' fundraising outlook was on the decline due to the Great Depression. Unwilling to pour in the necessary resources without a certainty that they could replenish their coffers, accepting funds directly from the government remained out of the question. The Great Depression brought in to view many of the inherent challenges in American economic arrangements, none perhaps as clearly as the limits of what the Associational State and voluntary philanthropy were capable of managing. The scholarship of the Hoover years already pointed in this direction when it came to managing economic production voluntarily. The last chapter in this study makes clear that the same struggles were evident in the nonprofit sector.

Yet, it is difficult to explain away the apparent lack of concern the American National Red Cross demonstrated for the people of Arkansas. In a debate between organizational effectiveness coupled with sustainability and doing immediate good on behalf of the afflicted, it is easy to dismiss the former as secondary to the latter. And 
certainly John Barton Payne did himself a disservice in the laissez faire approach presented to Congress. Distastefulness aside, the experience of the Red Cross in Arkansas is just one more, dramatic example of the choices faced by nonprofit corporations. Choices that must be recognized in historical research encompassing the works of organizations.

It is a scholarly blind spot - the unwillingness to understand large-scale charitable organizations as corporate in nature - that has left the telling of the nonprofit sectors impact on modern American history hollow. The experience of the United States Sanitary Commission, the Peabody Foundation, the Slater Fund, the Young Men's Christian Association, and the American National Red Cross all demonstrate an organizational yearning for a corporate culture. Even the Freedmen's Bureau, illustrating an approach to civil society that was ultimately abandoned, reinforced corporatization as foundational to stability, if not for itself then at least for those who received its funds. When America went back to war in 1917, and a new approach to organizing society and the economy was required to secure success: a governing alliance of the federal government, big business, and associations. Historian Ellis Hawley termed this strategy, which reached maturity in the Hoover Administration, the Associational State. While Hawley recognized nonprofit corporations played a role - the Red Cross and YMCA in particular - even he failed to understand how these organizations functioned within the system. Nor did he recognize that it was their corporate nature, akin in management and operations to for-profit corporations, that bought these organizations a seat at the table. At its base, nonprofit corporations competed for resources within the market economy, were created in the image of for-profit counterparts, while working as an ancillary of capitalism. They 
are the markets response to the need for a more robust civil society. Market competition then becomes the thread connecting these organizational stories, from the early experiment with the Associational State in the Civil War, to the apex of the alliance in the early 1930 s.

Frederick Law Olmsted faced much the same problems as the Red Cross in molding the United States Sanitary Commission into a proto-nonprofit corporation. When an underling bucked his policies regarding the distribution and acknowledgment of donations to see to it that the troops laying siege at Vicksburg received lemons from New York police officers, Olmsted was incapable of viewing this as an act of charity. In fact, Olmsted was unwilling to view this outcome as beneficial in any way - for him, the good works had ceased to exist, substituted as one of thousands of corporate outputs that week. Instead, he focused on a subordinate's unwillingness to work within the hierarchy, follow procedures, maintain unity of purpose among all donors, and make strategic use of resources. What was important to Olmsted was not a single act of charity, but the efficiency of a system that allocated donations to the soldiers most in need and able to benefit. It was cold blooded efficiency that inspired confidence among donors, allowing the mission to carry on. Meeting the immediate needs of donors or soldiers alike was not the end goal; winning the war required long-term strategic thinking emboldened by a strong corporate culture.

General Oliver O. Howard faced a similar problem, if approached from a different direction. With a clear understanding that his organization did not enjoy long-term prospects of operation, he instead focused on doing as much good as possible while resources were available. With clear eyed vision capable of dismissing partisanship and 
regional political agendas, modern scholars can see that much of Howard's financial management of the Freedman's Bureau was questionable at best, corrupt at worst. But it is also undeniable that Howard's mustering and distribution of financial resources was instrumental in expanding American civil society, in particular the creation and support of historically Black colleges and universities. Rather than focus on perpetuating the Bureau's existence - an organization whose days he recognized were numbered Howard worked hard to ensure the perpetuation of those receiving funds. While the Freedman's Bureau operated without significant checks on their spending or operations, that was not the same for organizations receiving the Bureau's largess. For Howard, his organization's long-term impact was ensuring that the organizations filling the gap following the bureau's demise were positioned as corporate entities so as to sustainably function into the future.

Not all future philanthropic funders were as cavalier about their own organization's operations. In the Peabody Foundation and Slater Fund the need to operate within a corporate culture was immediately evident, especially the Slater Fund Board's frustration with the General Agent's decidedly non-corporate way of doing things. Both organizations recognized that they would not exist in perpetuity - that was neither the intent of the founders nor the historical outcome of either organization - but to maximize the impact of their large, but limited funds, a corporate culture was necessary. Much like the Freedman's Bureau, both foundations expected the organizations they supported to make efficient use of funds. That required a corporate culture augmented with clear managerial controls. In a step further than the Bureau, positive and measurable outcomes became key to future funding. While this may seem a given, this was an important step in 
the development of modern philanthropy. By tying future funding to outcomes, and requiring the systems and culture in place to meet those expectations, these foundations changed the relationship between large donors and organizations. Transitioning from amateurish charity to nonprofit corporation became the norm.

But this was not just an expectation of large foundations with the clout and resources to alter an organization's culture. The Young Men’s Christian Association, with its decentralized nature, became an experiment in creating a corporate culture. As each chapter set its own course, not just in personnel, policies, and management, but in actual services offered and mission execution, it was impossible for the national coordinating committee to require much of anything. Few who were not highly involved members of a YMCA would ever have guessed this was the arrangement. With an organizational landscape that invited diversity and experimentation, chapters instead chose to adopt a strongly corporatist culture, informed by a duplication of mission and operations. Fundraising efforts, regardless of which chapter launched them, looked similar. The gymnasiums worked from the same core ideas of physical fitness and facilities management. And rather than coming from a centralized planning office, conformity among chapters came from the members themselves. Partly a reflection of the need to find organizational stability - having begun from an unsustainable vision - and partly reflective of the economic aspirations of members, the YMCA became a full nonprofit corporation. Not through a grand plan, but by a serious of independent, locally made decisions regarding policies and procedures, financial management, and operational necessities. Given the development of corporate cultures within for-profit organizations, this should not strike us as an odd revelation. Such has been the lack of attention paid by 
historians to the operational realities of charitable organizations that these issues have been ignored by the existing scholarship.

The expectation of a corporate culture, and how that was defined, becomes more evident when attention is turned to the experience of the Red Cross. While Clara Barton was an American folk hero, and an undeniable national expert at bringing relief to the victims of calamity, that did not offer her an escape from those expectations. She had a personality that could be described as a force of nature, and almost boundless energy, which helped her to overcome the need to corporatize her organization early in its life. On one hand, it was hard to deny the effectiveness of her management. On the other, her leadership of the organization included a strong policy of returning sufferers to the economic fold as quickly as possible, avoiding the perception of instigating pauperism, and positioning the Red Cross as a corollary of the free market system. Barton's energy and care for the suffering of others could only propel the organization to support capitalism, while not reflecting it, for so long. As pressure mounted for the Red Cross to become more driven by a corporate culture, with a clear hierarchy, financial management practices, and policies and procedures, Barton herself was rendered an anomaly. An assumption of corporations at the time, whether for-profit or nonprofit, was that only men could effectively lead. As Barton's leadership proved problematic for the crusaders of corporatization, embarrassing discussions of oversight and shortcomings could largely be avoided by dismissing her purely as a product of her gender. A truly corporatized nonprofit corporation required male leadership.

A strong corporate culture led to a number of positives for the organizations that adopted them. Clear policies and procedures produced measurable and predictable 
outcomes. In turn, this demonstrated reliability to potential donors, resulting in increased resources. An increase in resources made future outcomes even more predictable, further ensuring needed funding. Corporatization was a path to positive self-fulfilling prophecies. As the strength of an organization increased one last metric to ensure success could be achieved: recognition from the federal government that a nonprofit corporation was deserving of a seat within the Associational State. For the United States Sanitary Commission that came begrudgingly when the War Department was forced to recognize the efficacy of their operations and the power inherent in their organizational culture. For the YMCA and the Red Cross, that moment came in World War I.

For those two organizations, the stability brought by their corporatized cultures and strength of operations was recognized for the beginning, making their inclusion in the war effort a default rather than an anomaly. Even prior to the entrance of the United States to the conflict, both organizations inserted themselves into the global conflict, finding ways to mitigate the suffering among belligerents and victims alike. And rather than finding themselves flatfooted when America declared war, both groups, demonstrating the prowess of their corporate cultures, overhauled operations, hierarchies, and scope of operations in preparation for the coming of battle. When the United States entered the war, the YMCA and Red Cross were well positioned to assist the war effort, and did so admirably. The letters home from soldiers engaged in the conflict make clear the real and meaningful impact both organizations had on the troops' everyday lives.

Of course, the Associational State proved flawed. Relying on the voluntaristic spirit of the American people - a spirit suppressed to some degree by the Great Depression - exposed the limits of what a civil society rooted in the market driven 
distribution of resources was capable of addressing. What Hoover missed in theorizing the Associational State was that nonprofit corporations, as part and parcel of the capitalist system, would also suffer during economic catastrophe. Their vision equally focused on mission and long-term stability, as in the Red Cross operations during the Arkansas drought, left nonprofit corporations without a clear path. Groping in the dark for safety, much like their for-profit cousins, nonprofit corporations failed to respond to challenges in a way that placed national interest above organizational goals. Nor should they have been expected to. Corporations are simply not built that way.

None of this is to say that the Associational State has not persisted into the present. As much as the Great Depression begot the New Deal, bringing a massive expansion of government services, programs, and direct aid, holes in civil society persisted. As my friends from Azerbaijan found, those needs remain significant, with organizations filling the gaps to such a degree to fully constitute a third sector of the economy. According to Independent Sector, a membership-based organization serving nonprofit leaders, the voluntary sector of the American economy is responsible for approximately $10 \%$ of all economic activity. ${ }^{1}$ The federal government continues to coordinate with these organization and embraces voluntary cooperation to solve social ills. The Red Cross still responds to natural disasters. In 2010, research indicated that almost one if every three dollars distributed to nonprofit organizations came from government sources (be they federal, state, or local). ${ }^{2}$ While today's version of the

1 “The Charitable Sector," Independent Sector, accessed September 27, 2020, https://independentsector.org/about/the-charitable-sector/.

${ }^{2}$ Sarah L. Pettijohn, "Nonprofits and Governments: a Mutually Dependent Relationship," Urban Institute, May 13, 2015, https://www.urban.org/urbanwire/nonprofits-and-governments-mutually-dependent-relationship. 
Associational State may look more like the Freedman's Bureau model than Hoover's vision, cooperation between government and organizations to meet society's needs, remains undeniable. While not all problems will, could, or should be addressed by this system, the Associational State persists. 


\section{BIBLIOGRAPHY}

\section{$\underline{\text { Primary Sources }}$}

“12 $2^{\text {th }}$ Annual Report: St. Louis Young Men's Christian Association.” 1888. Young Men's Christian Association, St. Louis Chapter (1853-), Records, Folder 8, Box 1, SHSM-S.

“13 ${ }^{\text {th }}$ Annual Report: St. Louis Young Men's Christian Association.” 1889. Men's Christian Association, St. Louis Chapter (1853-), Records, Folder 9, Box 1, SHSM-S.

“1 $14^{\text {th }}$ Annual Report: St. Louis Young Men's Christian Association.” 1890. Young Men's Christian Association, St. Louis Chapter (1853-), Records, Folder 9, Box 1, SHSM-S.

“15 ${ }^{\text {th }}$ Annual Report: St. Louis Young Men's Christian Association." 1891. Young Men's Christian Association, St. Louis Chapter (1853-), Records, Folder 9, Box 1, SHSM-S.

" $16^{\text {th }}$ Annual Report of the St. Louis Young Men's Christian Association." 1892. Young Men's Christian Association, St. Louis Chapter (1853-), Records, Folder 9, Box 1 , SHSM-S.

“Above the Gloom.” Milwaukee Daily Sentinel. Milwaukee, WI. Jun. 6, 1889.

“About Hygiene." Vanity Fair. Oct. 26, 1861. Accessed via "Illustrated Civil War Newspapers and Magazines."

"A Complimentary Letter from the Kentucky Sanitary Commission." The Scientific American. Jan. 31, 1863. Accessed via "Illustrated Civil War Newspapers and Magazines."

“Advertisements.” The Echo. Vol. II. June 1889. Santa Cruz, CA, Local YMCAs (Y.USA.66), Kautz Family YMCA Archives, University of Minnesota Libraries.

"A Fortnight with the Sanitary." The Atlantic Monthly. Feb. 1865. Accessed via "Illustrated Civil War Newspapers and Magazines."

“A Ghastly Find.” Los Angeles Times. Los Angeles, CA. Jun. 9, 1889.

“Aid for the Sufferers." Galveston Daily News. Galveston, TX. Feb. 16, 1884. 
"All Sorts Things." New York Illustrated News. Apr. 20, 1864. Accessed via "Illustrated Civil War Newspapers and Magazines."

“A Mission of Mercy.” Galveston Daily News. Galveston, TX. Feb. 2, 1887.

"An Appalling Disaster." Grand Forks Daily Herald. Grand Forks, North Dakota. Sept. 11, 1900.

“An Appeal.” Cleveland Daily Herald. Cleveland, OH. Sept. 15, 1881.

"An Appeal: To the Human of the United States." Cleveland Daily Herald. Cleveland, Oh. Sept. 15, 1881.

Annual Announcement, 1904-05. Kane, PA Young Men's Christian Association: Kane, PA: 1905. Pennsylvania: Grove City, Kane, Lewistown, Local YMCAs (Y.USA.66), Kautz Family YMCA Archives, University of Minnesota Libraries.

“A Noble Little Girl.” New York Illustrated News. Mar. 19, 1864. Accessed via "Illustrated Civil War Newspapers and Magazines."

“Another Appeal.” Milwaukee Daily Sentinel. Milwaukee, WI. Sept. 15, 1881.

"Army and Navy Items." Harper's Weekly. Jan. 23, 1864. Accessed via "Illustrated Civil War Newspapers and Magazines."

“As Might be Expected.” Daily Inter Ocean. Chicago, IL. Sept. 20, 1881.

“Association of the Red Cross.” Daily Inter Ocean. Chicago, IL. Nov. 12, 1881.

“A Valley of Death.” Milwaukee Journal. Milwaukee, WI. Jun. 1, 1889.

“Autograph Leaves." Harper's Weekly. May 28, 1864. Accessed via "Illustrated Civil War Newspapers and Magazines."

Bacon, Leonard W. "Leonard W. Bacon to Rutherford B. Hayes, Oct. 10, 1881." Teach the Freeman: The Correspondence of Rutherford B. Hayes and the Slater Fund for Negro Education, 1881-1887. Baton Rouge: Louisiana State University Press, 1959.

Bacon Leonard W. "Leonard W. Bacon to Rutherford B. Hayes, Oct. 26, 1881.” Teach the Freeman. Baton Rouge: Louisiana State University Press, 1959.

Bacon, Leonard W. "Leonard W. Bacon to Rutherford B. Hayes, Jan. 18, 1882." Teach the Freeman. Baton Rouge: Louisiana State University Press, 1959. 
Bacon, Leonard W. "Leonard W. Bacon to Rutherford B. Hayes, Mar. 15, 1882." Teach the Freeman. Baton Rouge: Louisiana State University Press, 1959.

Bacon, Leonard W. "Leonard W. Bacon to Rutherford B. Hayes Jul. 21, 1882." Teach the Freeman. Baton Rouge: Louisiana State University Press, 1959.

Bacon, Leonard W. "Leonard W. Bacon to Rutherford B. Hayes May 5, 1882." Teach the Freeman. Baton Rouge: Louisiana State University Press, 1959.

Balog, Newton. "Letter to Brother, July 4, 1918." Seven Letters Written By Newton Balog.

Balog, Newton. "Letter to Father, October 15, 1918." Seven Letters Written By Newton Balog.

Andrews, Paul F. “Letter to Uncle Oscar, July 5, 1918.” Letters Written by Paul F. Andrews.

Andrews, Paul F. "Letter to Uncle Oscar, July 18, 1918." Letters Written by Paul F. Andrews.

“Barbarism.” Harper's Weekly. Dec. 24, 1864. Accessed via "Illustrated Civil War Newspapers and Magazines.

Barton, Clara. "More Help Needed.” Daily Inter Ocean. Chicago, IL. Jun. 25, 1889.

Bickers, R.E. “Letter to Hoover, Aug. 4, 1930.” Aug. 4, 1930. President's Subject Files, Drought Correspondence Box 134, Hoover Presidential Library.

Board of Trustees. The American National Red Cross: Annual Report. Washington, DC: American National Red Cross, 1918.

Board of Trustees of the John F. Slater Fund. "Resolution Jan. 18, 1885." Teach the Freeman. Baton Rouge: Louisiana State University Press, 1959.

"Building of the Northwestern Sanitary Commission and Soldiers' Home." Harper's Weekly. June 17, 1865. Accessed via "Illustrated Civil War Newspapers and Magazines."

Castleman, Alfred Lewis Diary of Alfred Lewis Castleman. Accessed via "Illustrated Civil War Newspapers and Magazines.

“Chicago Sympathy.” Daily Inter Ocean. Chicago, IL. Sept. 12, 1881. 
“C.K. Ober is Dead; Y.M.C.A Pioneer, 92: 'Master Recruiter,' Regional Secretary 40 Years, Was an Associate of John R. Mott." The New York Times. Jul. 15, 1948, 23.

“Clara Barton at Johnstown.” Daily Inter Ocean. Chicago, IL. Jun. 23, 1889.

"Clara Barton is Very Ill." Wilke-Barre Weekly Times. Wilkes-Barre, PA. Oct. 27, 1900.

Cole, Catherine. "A Sermon to Young Women." New Orleans Times-Picayune. New Orleans, LA. Mar. 23, 1884.

Committee on Education and Labor. Charges Against General Howard. Washington, DC: House of Representatives, 1870.

Cover Page. Frank Leslie's Illustrated Newspaper. Apr. 9, 1864. Accessed via "Illustrated Civil War Newspapers and Magazines."

Couch, Harry C. “Telegram to Hoover.” Dec. 22, 1930. Presidential Papers-Subject File: Drought-Correspondence 1930, Oct.-Dec., Hoover Presidential Library, 1.

Cunningham, T.M. “Address Before the St. Louis Young Men's Christian Association at its First Public Meeting." Nov. 20, 1853. Young Men's Christian Association, St. Louis Chapter (1853-), Records, Folder 1, Box 1, State Historical Society of Missouri-St. Louis (hereafter cited as SHSM-S).

Curry, J.L.M. “J.L.M. Curry to Rutherford B. Hayes Jul. 8, 1882.” Teach the Freeman. Baton Rouge: Louisiana State University Press, 1959).

Curry, J.L.M. "J.L.M. Curry to Rutherford B. Hayes Jul 17, 1882." Teach the Freeman. Baton Rouge: Louisiana State University Press, 1959.

Curry, J.L.M. "J.L.M. Curry to Rutherford B. Hayes Apr. 8, 1891.” Teach the Freeman. Baton Rouge: Louisiana State University Press, 1959. Vol. II.

Davis, George W. Ninth Annual Report of the American National Red Cross. American National Red Cross: Washington, DC, Jun. 10, 1914.

Davis, George W. Tenth Annual Report of the American National Red Cross. American National Red Cross: Washington, DC, Mar. 4, 1915.

Debt Subscription Card, 1907. Kane, PA Young Men's Christian Association: Kane, PA 1907. Pennsylvania: Grove City, Kane, Lewistown, Local YMCAs (Y.USA.66), Kautz Family YMCA Archives, University of Minnesota Libraries.

"Devastation." Atchison Globe. Atchison, KS. Jun. 6, 1889. 
Dodge, William W. "William E. Dodge to Rutherford B. Hayes Aug 8, 1882." Teach the Freeman. Baton Rouge: Louisiana State University Press, 1959.

Dodge, Jr., William E. "William E. Dodge, Jr. to Rutherford B. Hayes.” Teach the Freeman. Baton Rouge: Louisiana State University Press, 1959

“Domestic Intelligence." Harper's Weekly. Feb. 18, 1864. Accessed via "Illustrated Civil War Newspapers and Magazines."

“Dr. G. W. Scollay's.” The Scientific American, Feb. 28, 1863. Accessed via "Illustrated Civil War Newspapers and Magazines."

“Dr. Henry W. Bellows of New York.” Frank Leslie's Illustrated Newspaper. Apr. 16, 1864. Accessed via "Illustrated Civil War Newspapers and Magazines."

DuBois, W.E.B. "W.E.B. DuBois to Rutherford B. Hayes Nov. 4, 1890." Teach the Freeman. Baton Rouge: Louisiana State University Press, 1959. Vol. II.

DuBois, W.E.B. "W.E.B. DuBois to Rutherford B. Hayes, Apr. 3, 1892." Teach the Freeman. Baton Rouge: Louisiana State University Press, 1959. Vol. II.

DuBois, W.E.B. "W.E.B. DuBois to Rutherford B. Hayes May 25, 1891." Teach the Freeman. Baton Rouge: Louisiana State University Press, 1959. Vol. II.

"Editors Table." Continental Monthly. March, 1864. Accessed via "Illustrated Civil War Newspapers and Magazines."

“Epitome of the Week." Frank Leslie's Illustrated Newspaper. Dec. 13, 1862. Accessed via "Illustrated Civil War Newspapers and Magazines."

“Epitome of the Week." Frank Leslie's Illustrated Newspaper. Mar. 26, 1864. Accessed via "Illustrated Civil War Newspapers and Magazines."

"Epitome of the Week." Frank Leslie's Illustrated Newspaper. Apr. 9, 1864. Accessed via "Illustrated Civil War Newspapers and Magazines."

Fieser, James L. “Confidential Letter to Central Committee.” Presidential Papers Subject File: American National Red Cross, Correspondence 1930 JulyDecember, Hoover Presidential Library.

“Fire Follows the Flood.” Wisconsin State Register. Portage, WI. Jun. 29, 1889.

"First Annual Report of the Young Men's Christian Association of Abilene, Kansas." 1888. Kansas YMCAs, Local YMCAs (Y.USA.66), Kautz Family YMCA Archives, University of Minnesota Libraries. 
First Year Book of the Young Men's Christian Association of Greensburg, PA. Young Men's Christian Association: Greensburg, PA, 1890. Pennsylvania: Greensburg Folder I, Local YMCAs (Y.USA.66), Kautz Family YMCA Archives, University of Minnesota Libraries.

“Flood Relief Completed.” Milwaukee Daily Sentinel. Milwaukee, WI. May 29, 1884.

“Flood Sufferers.” Milwaukee Daily Sentinel. Milwaukee, WI. Feb. 19, 1884.

"Frail and Worn Homeward Bound, Miss Clara Barton Passes Through New Orleans Again.” Times-Picayune. New Orleans, LA. Nov. 16, 1900.

“Galveston Relief Worse.” Baltimore Sun. Baltimore, MD. Nov. 27, 1900.

Gilman, Daniel Coit "Daniel Coit Gilman to Rutherford B. Hayes Oct. 19, 1889." Teach the Freeman: The Correspondence of Rutherford B. Hayes and the Slater Fund for Negro Education, 1881-1887. Baton Rouge: Louisiana State University Press, 1959. Vol. II.

Gilman, Daniel Coit "Daniel Coit Gilman to Rutherford B. Hayes Dec. 15, 1882." Teach the Freeman.Baton Rouge: Louisiana State University Press, 1959.

Gilman, Daniel Coit. "Daniel Coit Gilman to Rutherford B. Hayes Feb. 1, 1884." Teach the Freeman. Baton Rouge: Louisiana State University Press, 1959

Gilman, Daniel Coit. "Daniel Coit Gilman to W.E.B. DuBois May 23, 1892." Teach the Freeman. Baton Rouge: Louisiana State University Press, 1959. Vol. II.

Hartzell, J.C. "J.C. Hartzell to Rutherford B. Hayes Oct. 24, 1889." Teach the Freeman. Baton Rouge: Louisiana State University Press, 1959.

Hayes, Rutherford B. "Rutherford B. Hayes to Atticus G. Haygood Aug 24, 1891." Teach the Freeman. Baton Rouge: Louisiana State University Press, 1959. Vol. II.

Hayes, Rutherford B. "Rutherford B. Hayes to Daniel Coit Gilman Dec. 11, 1882.” Teach the Freeman. Baton Rouge: Louisiana State University Press, 1959

Hayes, Rutherford B. "Rutherford B. Hayes to J.L.M. Curry Jul. 15, 1882." Teach the Freeman. Baton Rouge: Louisiana State University Press, 1959.

Hayes, Rutherford B. "Rutherford B. Hayes to Morris K. Jesup, Nov. 23, 1882." Teach the Freeman. Baton Rouge: Louisiana State University Press, 1959.

Haygood, Atticus G. "Atticus G. Haygood to Finance Committee of the Slater Fund May 11, 1889." Teach the Freeman. Baton Rouge: Louisiana State University Press, 1959. Vol. II. 
Haygood, Atticus G. "Atticus G. Haygood to Leonard W. Bacon, Jan. 25, 1882.” Teach the Freeman. Baton Rouge: Louisiana State University Press, 1959.

Haygood, Atticus G. “Atticus G. Haygood to Rutherford B. Hayes Aug 31, 1882." Teach the Freeman. Baton Rouge: Louisiana State University Press, 1959

Haygood, Atticus G. “Atticus G. Haygood to Rutherford B. Hayes Dec. 6, 1882." Teach the Freeman. Baton Rouge: Louisiana State University Press, 1959.

Haygood, Atticus G. "Atticus G. Haygood to Rutherford B. Hayes Feb. 1, 1883.” Teach the Freeman. Baton Rouge: Louisiana State University Press, 1959.

Haygood, Atticus G. “Atticus G. Haygood to Rutherford B. Hayes Mar. 3, 1883.” Teach the Freeman. Baton Rouge: Louisiana State University Press, 1959.

Haygood, Atticus G. “Atticus G. Haygood to Rutherford B. Hayes Jun 7, 1883.” Teach the Freeman. Baton Rouge: Louisiana State University Press, 1959.

Haygood, Atticus G. "Atticus G. Haygood to Rutherford B. Hayes Jun 30, 1883.” Teach the Freeman. Baton Rouge: Louisiana State University Press, 1959.

Haygood, Atticus G. “Atticus G. Haygood to Rutherford B. Hayes Sep. 19, 1883.” Teach the Freeman. Baton Rouge: Louisiana State University Press, 1959.

Haygood, Atticus G. "Atticus G. Haygood to Rutherford B. Hayes Jun. 18, 1884.” Teach the Freeman. Baton Rouge: Louisiana State University Press, 1959.

Haygood, Atticus G. “Atticus G. Haygood to Rutherford B. Hayes Mar. 30, 1885.” Teach the Freeman. Baton Rouge: Louisiana State University Press, 1959

Haygood, Atticus G. “Atticus G. Haygood to Rutherford B. Hayes May 4, 1885.” Teach the Freeman. Baton Rouge: Louisiana State University Press, 1959.

Haygood, Atticus G. “Atticus G. Haygood to Rutherford B. Hayes Jan. 13, 1886.” Teach the Freeman. Baton Rouge: Louisiana State University Press, 1959.

Haygood, Atticus G. “Atticus G. Haygood to Rutherford B. Hayes Feb. 12, 1886." Teach the Freeman. Baton Rouge: Louisiana State University Press, 1959.

Haygood, Atticus G. “Atticus G. Haygood to Rutherford B. Hayes Jan. 12, 1887.” Teach the Freeman. Baton Rouge: Louisiana State University Press, 1959.

Haygood, Atticus G. "Atticus G. Haygood to Rutherford B. Hayes Nov. 21, 1887.” Teach the Freeman. Baton Rouge: Louisiana State University Press, 1959. 
Haygood, Atticus G. "Atticus G. Haygood to Rutherford B. Hayes Nov. 28, 1890." Teach the Freeman. Baton Rouge: Louisiana State University Press, 1959. Vol. II.

"Heart Rending Holocaust." The St. Louis Globe-Democrat. St. Louis, MO. Sept. 10, 1881.

“Higher Than Ever.” Milwaukee Daily Sentinel. Milwaukee, WI. Feb. 12, 1884.

Hoadly, George. “The Ohio Deluge.” Milwaukee Daily Sentinel. Milwaukee, WI. Feb. $13,1884$.

Hoover, Hoover. "Letter to John Barton Payne." Jan. 10, 1931. Presidential Papers Subject File: American National Red Cross, Correspondence 1930 JulyDecember, Hoover Presidential Library.

Hoover, Hoover. "Statement on the Drought." Aug. 5, 1930. The American Presidency Project.

Hoover, Herbert. "Statement on the Organization of Drought Relief." The American Presidency Project. Aug. 19, 1930.

Hoover, Herbert. "Statement on the White House Conference on Drought Relief." The American Presidency Project. Aug. 14, 1930.

Hoover, Herbert. “Telegram to Honorable Joe T. Robinson, Aug. 6, 1930.” Aug. 6, 1930. Drought Correspondence Box 134, Hoover Presidential Library.

Hoover, Herbert. "White House Statement of the Formation of a Committee of Leading Citizens to Aid the Red Cross Drought Relief Campaign." The American Presidency Project. Jan. 18, 1931.

Hosmer, James Kendall. Diary of James Kendall Hosmer. Accessed via "Illustrated Civil War Newspapers and Magazines."

"Inauguration of the Central Sanitary Fair, Philadelphia." Frank Leslie's Illustrated Newspaper. June 25, 1864. Accessed via "Illustrated Civil War Newspapers and Magazines."

International Committee of Young Men's Christian Associations. Year Book of the Young Men's Christian Associations of North America, May 1, 1913 to April 30, 1914. New York: Association Press, 1914.

International Committee of Young Men's Christian Associations. Year Book of the Young Men's Christian Associations of North America, May 1, 1914 to April 30, 1915. New York: Association Press, 1915. 
International Committee of the Young Men's Christian Associations. Year Book of the Young Men's Christian Associations of North America, May 1, 1915 to April 30, 1916. New York: Association Press, 1916.

Irons, Charles Glen. Letters Written by Dr. Charles Glen Irons to His Wife and Daughter in Chicago, Illinois.

Irons, Charles Glen “Dr. Charles Irons to Family, Oct. 18, 1918.” Letters Written by Dr. Charles Glen Irons to His Wife and Daughter in Chicago, Illinois.

Jennings, W.K. Business Management in Our Associations. 1891. YMCA Business Administration Commission Reports, Miscellaneous YMCA Research, Planning, and Development Records (Y.USA.34), Kautz Family YMCA Archives, University of Minnesota Libraries.

Jerome, David H. "The Michigan Calamity." Independent Statesman. Concord, NH. Sept. 22,1881 .

“Johnstown Contributions.” Milwaukee Daily Sentinel. Milwaukee, WI. Jun. 15, 1889.

Kane Y.M.C.A Basket and Baseball '07 and '08 Schedule. Kane, PA Young Men's Christian Association: Kane, PA 1907. Pennsylvania: Grove City, Kane, Lewistown, Local YMCAs (Y.USA.66), Kautz Family YMCA Archives, University of Minnesota Libraries.

Kane, PA, November 18, 1907. Kane, PA Young Men's Christian Association: Kane, PA 1907. Pennsylvania: Grove City, Kane, Lewistown, Local YMCAs (Y.USA.66), Kautz Family YMCA Archives, University of Minnesota Libraries.

Application for Membership. Kane, PA Young Men's Christian Association: Kane, PA c. 1901-09. Pennsylvania: Grove City, Kane, Lewistown, Local YMCAs (Y.USA.66), Kautz Family YMCA Archives, University of Minnesota Libraries.

Laudemann, F.D. “Telegram to Hoover.” Jan. 19, 1931. Presidential Papers - Secretary's File: Harvey Couch, Hoover Presidential Library.

"Letter for the Secretary of the American National Red Cross Transmitting the Report for the Year Ended December 31, 1904."

"Literary and Art Gossip.” New York Illustrated News. Jun. 4, 1864. Accessed via "Illustrated Civil War Newspapers and Magazines."

"Marked Articles for the Soldiers." The Scientific American. Apr. 9, 1864. Accessed via "Illustrated Civil War Newspapers and Magazines." 
"Medical Red Tape." Vanity Fair. Nov. 2, 1861. Accessed via "Illustrated Civil War Newspapers and Magazines."

"Memorial of Officers and Members of the American National Red Cross, Relating to Amended By-Laws Recently Adopted at a Meeting of that Organization."

“Michigan’s Scourge of Fire.” Galveston Daily News. Galveston, TX/ Sept. 14, 1881.

“Ministering Angel.” Rocky Mountain News. Denver, CO. Oct. 6, 1889.

"Miscellaneous Summary." The Scientific American. Apr. 9, 1864. Accessed via "Illustrated Civil War Newspapers and Magazines."

“Mississippi Valley Sanitary Fair." Harper's Weekly. May 14, 1864. Accessed via "Illustrated Civil War Newspapers and Magazines."

Mitchell, E.C. "E.C. Mitchell to Henry Lyman Morehouse Dec. 19, 1889." Teach the Freeman. Baton Rouge: Louisiana State University Press, 1959. Vol. II.

“Miss Clara Barton.” Galveston Daily News. Galveston, TX. Feb. 12, 1887.

“Miss Clara Barton Dangerously Ill.” Columbus Daily Enquirer. Columbus, Georgia. Oct. 25, 1900.

"Miss Clara Barton has been Visiting the Drought Districts of Texas." Rocky Mountain News. Denver, CO. Feb. 23, 1887.

“Multiple News Items.” Daily Inter Ocean. Chicago, IL. Sept. 9, 1881.

“Multiple News Items." Milwaukee Daily Sentinel. Milwaukee, WI. Sept. 21, 1881.

“Multiple News Items." Milwankee Daily Sentinel. Milwaukee, WI. Sept. 24, 1881.

"Multiple News Items." Southwester Christian Advocate. New Orleans, LA. Sept. 22, 1881.

“Munificent Contribution from San Francisco.” The Scientific American. Oct. 4, 1862. Accessed via "Illustrated Civil War Newspapers and Magazines."

Murray, Arthur Eleventh Annual Report of the American National Red Cross. American National Red Cross: Washington, DC, Jul. 27, 1916.

"Normal Conditions Are Fast Being Restored in Galveston." Age-Herald. Birmingham, AL. Sept. 20, 1900. 
"Notes and Queries." Vanity Fair. Nov. 16, 1861. Accessed via "Illustrated Civil War Newspapers and Magazines."

Ober, C.K. Money a Spiritual Force in the Kingdom of God. The International Committee of Young Men's Christian Associations: New York, 1903. Stewardship, 1890-1915, Miscellaneous YMCA Research, Planning, and Development Records (Y.USA.34), Kautz Family YMCA Archives, University of Minnesota Libraries.

Oldfield, Mrs. W.A. “Letter to Hoover, Aug. 7, 1930.” Aug. 7, 1930. Drought Correspondence Box 134, Hoover Presidential Library.

Olmsted, Frederick Law. "Olmsted to Bellows, September 1st 1863 ." Ed. Jane Turner Censer. The Papers of Frederick Law Olmsted. Vol. IV. Baltimore: The Johns Hopkins Press, 1986.

“Our Privilege." Frank Leslie's Illustrated Newspaper. Dec. 6, 1862. Accessed via "Illustrated Civil War Newspapers and Magazines."

Payne, John Barton. "Statement of Hon. John Payne Barton, Chairman of the American National Red Cross." Jan. 5, 1931. Senate Report.

Peabody, George. "Letter of George Peabody" (1867). Trustees of the Peabody Education Fund, Proceedings of the Trustees of the Peabody Education Fund From Their Original Organization (Boston: John Wilson and Son, 1875.

"Prisoners of War. Letter from Mr. Mason," The Index. Feb 2., 1865.

"Proffers of Aid for the Stricken City." Age-Herald. Birmingham, AL. Sept. 11, 1900.

Publications of the International Committee of Young Men's Christian Association. New York: International Committee of the Young Men's Christian Association, 1901. Catalogs, 1885-1979, Miscellaneous YMCA Research, Planning, and Development Records (Y.USA.34), Kautz Family YMCA Archives, University of Minnesota Libraries.

"Purified by Fire." Daily Evening Bulletin. San Francisco, CA. Nov. 28, 1881.

"Purification by Fire.” Wisconsin State Register. Portage, WI. Jun. 15, 1889.

“Ready Assistance." Galveston Daily News. Galveston, TX. Feb. 15, 1884.

"Red Cross Aid to Drought Sufferers." St. Louis Globe-Democrat. St. Louis, MO. Jan 27, 1887.

“Red Cross Begins Work.” New Haven Register. New Haven, CT. Sept. 11, 1900. 
"Relief." Cleveland Daily Herald. Cleveland, OH. Sept. 12, 1881.

"Relief for Flood Sufferers.” North American. Philadelphia, PA. Feb. 11, 1884.

"Relief for Michigan.” Milwaukee Daily Sentinel. Milwaukee, WI. Sept. 14, 1881.

“Relief Measure.” St. Louis Globe-Democrat. St. Louis, MO. Feb. 24, 1884.

“Relief Work at Galveston.” Times-Picayune. New Orleans, LA. Oct. 7, 1900.

"Remarks of Chief Justice Chase." The Liberator. Mar. 10, 1865. Accessed via "Illustrated Civil War Newspapers and Magazines."

"Republican Institutions." The Boatswain's Whistle. Nov. 18, 1864. Accessed via "Illustrated Civil War Newspapers and Magazines."

"Rhubarb Wine for Sick Soldiers." The Scientific American. Jun. 6, 1863. Accessed via "Illustrated Civil War Newspapers and Magazines."

Robinson, Joe T. "Letter to Hoover, Aug. 5, 1930.” Aug. 5, 1930. Drought Correspondence Box 134, Hoover Presidential Library.

Schedule of Gymnasium Classes , 1906-07, of the Kane Young Men's Association. Kane, PA Young Men's Christian Association: Kane, PA 1906.

Schedule of Gymnasium Classes, 1907-08, of the Kane Young Men's Association. Kane, PA Young Men's Christian Association: Kane, PA 1907. Pennsylvania: Grove City, Kane, Lewistown, Local YMCAs (Y.USA.66), Kautz Family YMCA Archives, University of Minnesota Libraries.

Shaler, Nathaniel Southgate "Nathaniel Southgate Shaler to Rutherford B. Hayes Mar. 2, 1891." Teach the Freeman. Baton Rouge: Louisiana State University Press, 1959. Vol. II.

“Sickness Prevailing.” Daily Inter Ocean. Chicago, IL. Jun. 9, 1889.

"Sketches of the Metropolitan Fair." Harper's Weekly. Apr. 23, 1864. Accessed via "Illustrated Civil War Newspapers and Magazines."

Stille, Charles J. History of the United States Sanitary Commission. Philadelphia: J.B. Lippincott \& Co., 1866.

“Starving People in Texas.” St. Louis Globe-Democrat. St. Louis, MO. Jan. 25, 1887. 
“St. Louis Young Men's Christian Association.” Ud. c.1920s, Young Men's Christian Association, St. Louis Chapter (1853-), Records, Folder 33, Box 1, SHSM-S.

Smith, DeWitt. "Weekly Drought Relief Report.” Sep. 20, 1930. Presidential PapersSubject File: Drought-Correspondence 1930, Oct.-Dec., Hoover Presidential Library.

Subscription Card, 1907. Kane, PA Young Men's Christian Association: Kane, PA 1907. Pennsylvania: Grove City, Kane, Lewistown, Local YMCAs (Y.USA.66), Kautz Family YMCA Archives, University of Minnesota Libraries.

“Suffering at Johnstown.” Boston Daily Advertiser. Boston, MA. Oct. 7, 1889.

“Sufferers by the Flood.” Galveston Daily News. Galveston, TX. Feb. 13, 1884.

“Supplies for Flood Sufferers.” St. Louis Globe-Democrat. St. Louis, MO. May 8, 1884.

"The Citizen Will Decide: Whether Alton Shall Have a Y.M.C.A., With a WellFurnished Reading Room and Parlor, and a Well-Equipped Gymnasium, and the Accompanying Benefits.” 1887. Alton, Bowling Green, Corning, Local YMCAs (Y.USA.66), Kautz Family YMCA Archives, University of Minnesota Libraries.

"The Condition of our Soldiers." The Scientific American. Nov. 9, 1861. Accessed via "Illustrated Civil War Newspapers and Magazines."

“The Flooded Districts.” Bangor Daily Whig and Courier. Bangor, ME. Feb. 26, 1884.

“The Floods.” St. Louis Globe-Democrat. St. Louis, MO. Feb. 21, 1884.

“The Floods” St. Louis Globe-Democrat. St. Louis, MO. Feb. 23, 1884.

“The Floods.” St. Louis Globe-Democrat. St. Louis, MO. Mar. 31, 1884.

“The Flood Victims.” North American. Philadelphia, PA. Jun. 15, 1889.

“The Fire Record.” Cleveland Daily Herald. Cleveland, OH. Sept. 14, 1881.

“The Great Flood.” Weekly Register-Call. Black Hawk, CO. Jun. 14, 1889.

“The Idler About Town.” Frank Leslie's Illustrated Newspaper. Feb. 13, 1864. Accessed via "Illustrated Civil War Newspapers and Magazines."

“The Lounger." Harper's Weekly. July 6, 1861. Accessed via "Illustrated Civil War Newspapers and Magazines." 
“The Lounger." Harper's Weekly. Dec. 27, 1862. Accessed via "Illustrated Civil War Newspapers and Magazines."

"The Michigan Fires." Georgia Weekly Telegraph. Macon, Ga. Sept. 23, 1881.

"The Michigan Forest Fires." Southwestern Christian Advocate. New Orleans, LA. Sept. 15,1881 .

“The Red Cross.” Congregationalist. Boston, MA. Nov. 10, 1887.

“The Red Cross.” St. Louis Globe-Democrat. St. Louis, MO. Mar. 14, 1884.

“The Red Cross Relief Boat.” St. Louis Globe-Democrat. St. Louis, MO. Apr. 4, 1884.

"The Relief Organization Called 'The Society of the Red Cross' Which is Now Rendering Good Service.” St. Louis Globe-Democrat. St. Louis, MO. Feb. 19, 1884.

“The Sanitary Fair at Brooklyn.” Frank Leslie 's Illustrated Newspaper. Mar. 5, 1864. Accessed via "Illustrated Civil War Newspapers and Magazines."

The Tie. Young Men's Christian Association of Sedalia, MO: Sedalia, MO, September 1890. Kansas: Sedalia, Sterling, Wichita [Sedalia, MO is incorrectly included in this collection], Local YMCAs (Y.USA.66), Kautz Family YMCA Archives, University of Minnesota Libraries.

The Tie. Young Men's Christian Association of Sedalia, MO: Sedalia, MO, May 1891. Kansas: Sedalia, Sterling, Wichita [Sedalia, MO is incorrectly included in this collection], Local YMCAs (Y.USA.66), Kautz Family YMCA Archives, University of Minnesota Libraries.

The Tie. Young Men's Christian Association of Sedalia, MO: Sedalia, MO, December 1891. Kansas: Sedalia, Sterling, Wichita [Sedalia, MO is incorrectly included in this collection], Local YMCAs (Y.USA.66), Kautz Family YMCA Archives, University of Minnesota Libraries.

“The Truth About Galveston.” Philadelphia Inquirer. Philadelphia, PA. Oct. 11, 1900.

“The Work of Relief.” Milwaukee Journal. Milwaukee, WI. Apr. 5, 1884.

“Third Annual Report of the Saint Louis Young Men's Christian Association.” 1856. Young Men's Christian Association, St. Louis Chapter (1853-), Records, Folder 7, Box 1, SHSM-S.

“To Send Relief.” Milwaukee Daily Sentinel. Milwaukee, WI. Jun. 4, 1889. 
“Town Gossip.” Frank Leslie’s Illustrated Newspaper. May 7, 1864. Accessed via "Illustrated Civil War Newspapers and Magazines."

"Treatment of Federal Prisoners." The Index (reprinted from the Richmond Whig). July 15,1865 .

Trustees of the Peabody Education Fund. First Meeting of the Peabody Education Fund (1867). Reprinted in: Trustees of the Peabody Education Fund, Proceedings of the Trustees of the Peabody Education Fund From Their Original Organization. Boston: John Wilson and Son, 1875.

Trustees of the Peabody Education Fund. Third Meeting of the Trustees (1867). Reprinted in: Trustees of the Peabody Education Fund. Proceedings of the Trustees of the Peabody Education Fund From Their Original Organization. Boston: John Wilson and Son, 1875.

Trustees of the Peabody Education Fund. Fourth Meeting of the Trustees (1868). Reprinted in: Trustees of the Peabody Education Fund. Proceedings of the Trustees of the Peabody Education Fund From Their Original Organization. Boston: John Wilson and Son, 1875.

Trustees of the Peabody Education Fund. Fifth Meeting of the Trustees (1868). Reprinted in: Trustees of the Peabody Education Fund. Proceedings of the Trustees of the Peabody Education Fund From Their Original Organization. Boston: John Wilson and Son, 1875.

Trustees of the Peabody Education Fund. Sixth Meeting of the Trustees (1869). Reprinted in: Trustees of the Peabody Education Fund. Proceedings of the Trustees of the Peabody Education Fund From Their Original Organization. Boston: John Wilson and Son, 1875.

Trustees of the Peabody Education Fund. Eighth Meeting of the Trustees (1870). Reprinted in: Trustees of the Peabody Education Fund. Proceedings of the Trustees of the Peabody Education Fund From Their Original Organization. Boston: John Wilson and Son, 1875.

Trustees of the Peabody Education Fund. Tenth Meeting of the Trustees (1872). Reprinted in: Trustees of the Peabody Education Fund. Proceedings of the Trustees of the Peabody Education Fund From Their Original Organization. Boston: John Wilson and Son, 1875.

Trustees of the Peabody Education Fund. Eleventh Meeting of the Trustees (1873). Reprinted in: Trustees of the Peabody Education Fund. Proceedings of the Trustees of the Peabody Education Fund From Their Original Organization. Boston: John Wilson and Son, 1875. 
Trustees of the Peabody Education Fund. Twelfth Meeting of the Trustees (1874).

Reprinted in: Trustees of the Peabody Education Fund. Proceedings of the Trustees of the Peabody Education Fund From Their Original Organization. Boston: John Wilson and Son, 1875.

Uhl, Erskine. Suggestions Concerning the Financial Management of a Young Men's Christian Association. New York: The Executive Committee of the Young Men's Christian Associations of the United States and British Provinces, 1878. Suggestions Concerning the Financial Management of a Young Men's Christian Association 1878, Miscellaneous Research, Planning and Development Records (Y.USA.34), Kautz Family YMCA Archives, University of Minnesota Libraries.

“Uncle Sam's Pence.” Harper's Weekly. Feb. 13, 1864. Accessed via “Illustrated Civil War Newspapers and Magazines."

“United States Sanitary Commission." Harper's Weekly. Feb. 6, 1864. Accessed via "Illustrated Civil War Newspapers and Magazines."

Untitled. The Scientific American. Mar. 5, 1865. Accessed via "Illustrated Civil War Newspapers and Magazines."

United States Department of Agriculture Bureau of Agricultural Economics. "Memorandum on the Drought Situation as of August 1, 1930." Aug. 1, 1930. President's Subject Files, Drought Correspondence Box 134, Hoover Presidential Library.

U.S. Congress, Senate Committee on the Judiciary. "Repealing Certain Provisions of the Espionage Act.” (Washington, DC: United States Senate, Jun. 5, 1930.

Waite, Morrison R. "Morrison R. Waite to Rutherford B. Hayes May 22, 1884.” Teach the Freeman. Baton Rouge: Louisiana State University Press, 1959

Washington, Booker T. "Booker T. Washington to Atticus G. Haygood." Teach the Freeman. Baton Rouge: Louisiana State University Press, 1959. Vol. I.

"Washington: Progress of the Tariff Bill - A String of Charges Against Gen. Howard The Funding Bill - Mr. Bennett's Canal Bill - The Deficiency Bill Miscellaneous." The New York Times. Apr. 7, 1870.

Williams, Hamp. “Telegram to Hoover, Aug. 8, 1930.” Aug. 8, 1930. Drought Correspondence Box 134, Hoover Presidential Library.

"Work in Our New Home.” The Echo. Vol. II. June 1889. Santa Cruz, CA, Local YMCAs (Y.USA.66), Kautz Family YMCA Archives, University of Minnesota Libraries. 
Wright, H.C. "President's Message." Printed in "First Annual Report of the St. Louis Young Men's Christian Association.” 1877. Young Men's Christian Association, St. Louis Chapter (1853-), Records, Folder 8, Box 1, SHSM-S.

YMCA Central Committee. Journal of the First Annual Convention of Young Men's Christian Associations, 1854. YMCA Yearbooks, Directories, and Proceedings (Y.USA.56), Kautz Family YMCA Archives, University of Minnesota Libraries.

$\underline{\text { Secondary }}$

"Alfred Lewis Castleman," Wisconsin Historical Society, https://www.wisconsinhistory.org/Records/Article/CS6166.

Baggett, James Alex. Scalawags: Southern Dissenters in the Civil War and Reconstruction. Baton Rouge: Louisiana State University Press, 2004.

Balogh, Brian. The Associational State: American Governance in the Twentieth Century. Philadelphia: University of Pennsylvania Press, 2015.

Bremner, Robert. American Philanthropy. Chicago: University of Chicago Press, 1988.

DuBois, W.E.B. The Sociological Souls of Black Folk. Plymouth, UK: Lexington Books, 2011.

Elfenbein, Jessica I. The Making of a Modern City: Philanthropy, Civic Culture, and the Baltimore YMCA. Gainesville, FL: University of Florida Press, 2001.

Fitzgerald, Michael W. Splendid Failure: Postwar Reconstruction in the American South. Ivan R. Dee, 2008.

Foner, Eric. Reconstruction: America's Unfinished Revolution, 1863-1877. New York: First Perennial Classics, 2002.

Galambos, Louis. "The Emerging Organizational Synthesis in Modern American History," Business History Review. 1970.

Hall, Peter Dobkin. Inventing the Nonprofit Sector and Other Essays on Philanthropy, Volunteerism, and Nonprofit Organizations. Baltimore: Johns Hopkins University Press, 2001.

Hamilton, David E. "Herbert Hoover and the Great Drought of 1930." The Journal of American History. Mar. 1982.

Hammack, David C. Making the Nonprofit Sector in the United States. Bloomington: University of Indiana Press, 1998. 
Hawley, Ellis. "Herbert Hoover, the Commerce Secretariat, and the Vision of an "Associative State," 1921-1929." The Journal of American History. Jun. 1974.

Hawley, Ellis. The Great War and the Search for a Modern Order: A History of the American People and Their Institutions, 1917-1933. New York: St. Martin Press, 1979.

Hutchinson, John F. Champions of Charity: War and the Rise of the Red Cross. Boulder: Westview Press, 1996.

Jones, Marian Moser The American Red Cross From Clara Barton to the New Deal. Baltimore: Johns Hopkins University Press, 2013.

Kerber, Linda K. “Separate Spheres, Female Worlds, Woman's Place: The Rhetoric of Women's History." The Journal of American History. Jun. 1988.

Lupkin, Paula. Manhood Factories: YMCA Architecture and the Making of Modern Urban Culture. Minneapolis: University of Minnesota Press, 2010.

Lustig, Jeffrey. Corporate Liberalism: The Origins of Modern American Political Theory, 1890-1920. Berkeley: University of California Press, 1982.

Marsden, George M. Religion and American Culture. Belmont, CA: Wadsworth, 2001

Martin, Roger L. and Sally Osberg. "Social Entrepreneurship: The Case for Definition." Stanford Social Innovation Review. Spring 2007.

McCarthy, Kathleen. American Creed: Philanthropy and the Rise of Civil Society, 17001865. Chicago: University of Chicago Press, 2003.

McCarthy, Kathleen D. "Spreading the Gospel of Self-Denial: Thrift and Association in Antebellum America." ed. Joshua J. Yates and James Davison Hunter. Thrift and Thriving in America: Capitalism and Moral Order from the Puritans to the Present. New York: Oxford University Press, 2011.

Mcleod, David I. Building Character in the American Boy: The Boy Scouts, YMCA, and Their Forerunners, 1870-1920. Madison: University of Wisconsin Press, 1983.

Mettler, Suzanne and Andrew Milstein. “American Political Development from Citizens' Perspective: Tracking Federal Government's Presence in Individual Lives over Time." Studies in American Political Development. 2007.

Mills, Frederick V. “Atticus G. Haygood (1839-1896).” New Georgia Encyclopedia. 
Mjagkij, Nina. Light in the Darkness: African Americans and the YMCA, 1852-1946. Lexington: University of Kentucky Press, 2015.

Mushkat, Jeremy. Fernando Wood: A Political Biography. Kent, Ohio: Kent State University Press, 1990.

Pettijohn, Sarah L. "Nonprofits and Governments: a Mutually Dependent Relationship." Urban Institute. May 13, 2015, https://www.urban.org/urban-wire/nonprofits-andgovernments-mutually-dependent-relationship.

Putney, Clifford. Muscular Christianity: Manhood and Sports in Protestant America, 1880-1920. Cambridge: Harvard University Press, 2003.

Raynor, Jared. "The Return of Capacity Building." Stanford Social Innovation Review. Nov. 2014.

Richardson, Heather Cox. The Death of Reconstruction: Race, Labor, and Politics in the Post-Civil War North, 1865-1901. Boston: Harvard University Press, 2004.

Skowronek, Stephen. Building a New American State: The Expansion of National Administrative Capacities, 1877-1920. New York: Cambridge University Press, 1982.

Summers, Mark W. The Ordeal of the Reunion: A New History of Reconstruction. Chapel Hill: University of North Carolina Press, 2014.

“The Charitable Sector.” Independent Sector. Accessed September 27, 2020, https://independentsector.org/about/the-charitable-sector/.

Wiebe, Robert H. The Search for Order: 1877-1920. New York: Hill and Wang, 1967.

Zald, Mayer N. Organizational Change: The Political Economy of the YMCA. Chicago: University of Chicago Press, 1970.

Zunz, Olivier. Making America Corporate 1870-1920. Chicago: University of Chicago Press, 1990. 
VITA

Kory Paul Gallagher was born in Salinas, California and spent his childhood in Stockton, California. Like many who grew up in Stockton he delayed college, but was lucky enough to be employed by a dot com company, affording him the opportunity to live in Seattle, Washington and San Diego, California. Eventually he pursued higher education, first attending San Joaquin Delta Community College, ultimately transferring to the University of Missouri-Kansas City where he earned a Bachelor's degree in History. Enjoying his experience, Kory pursued a Master's degree in History at UMKC, while also completing a Master's in Public Administration with a focus on Nonprofit Management. From there he attended the University of Missouri to pursue a PhD in American Cultural History. While completing his PhD, Kory continued to work full time, teaching history at Kansas City Academy and the Pembroke Hill School. He served three years as Head of School at Kansas City Academy before joining the faculty at the Barstow School. Kory lives in Kansas City, Missouri, where he serves the students of the Barstow School as the Assistant Director of the Middle and Upper Schools. 